DOE/EIA-0597

8

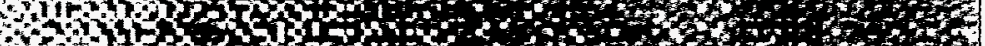

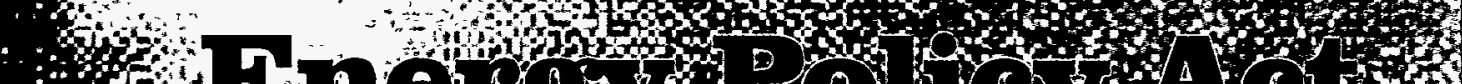

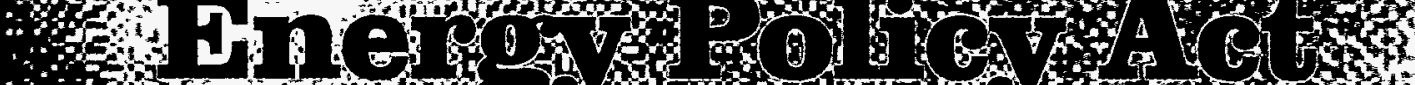

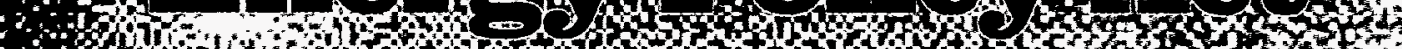

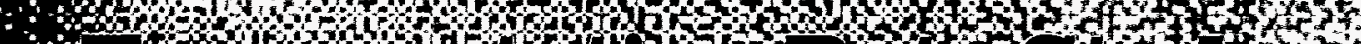
(x)

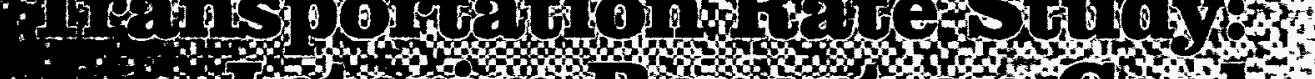

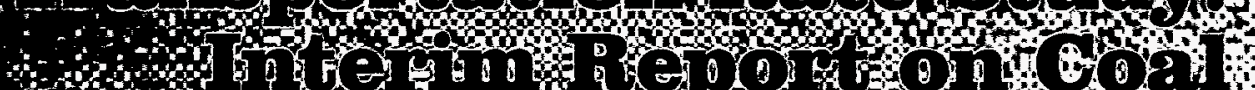

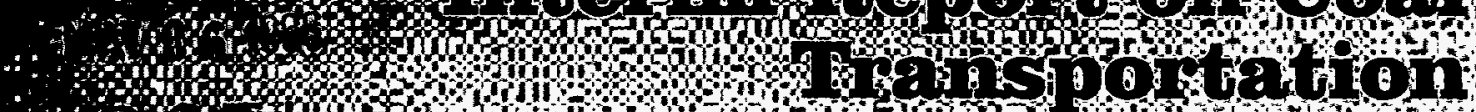

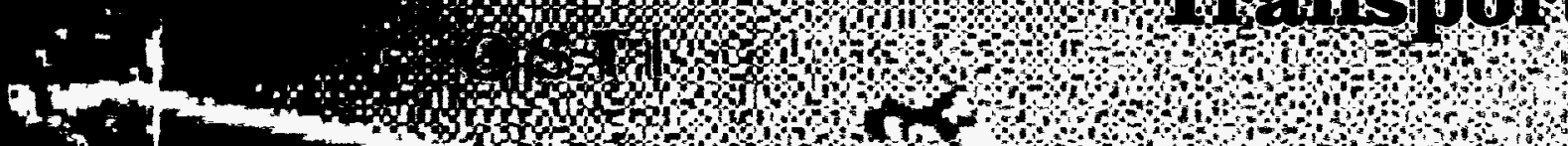

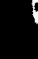
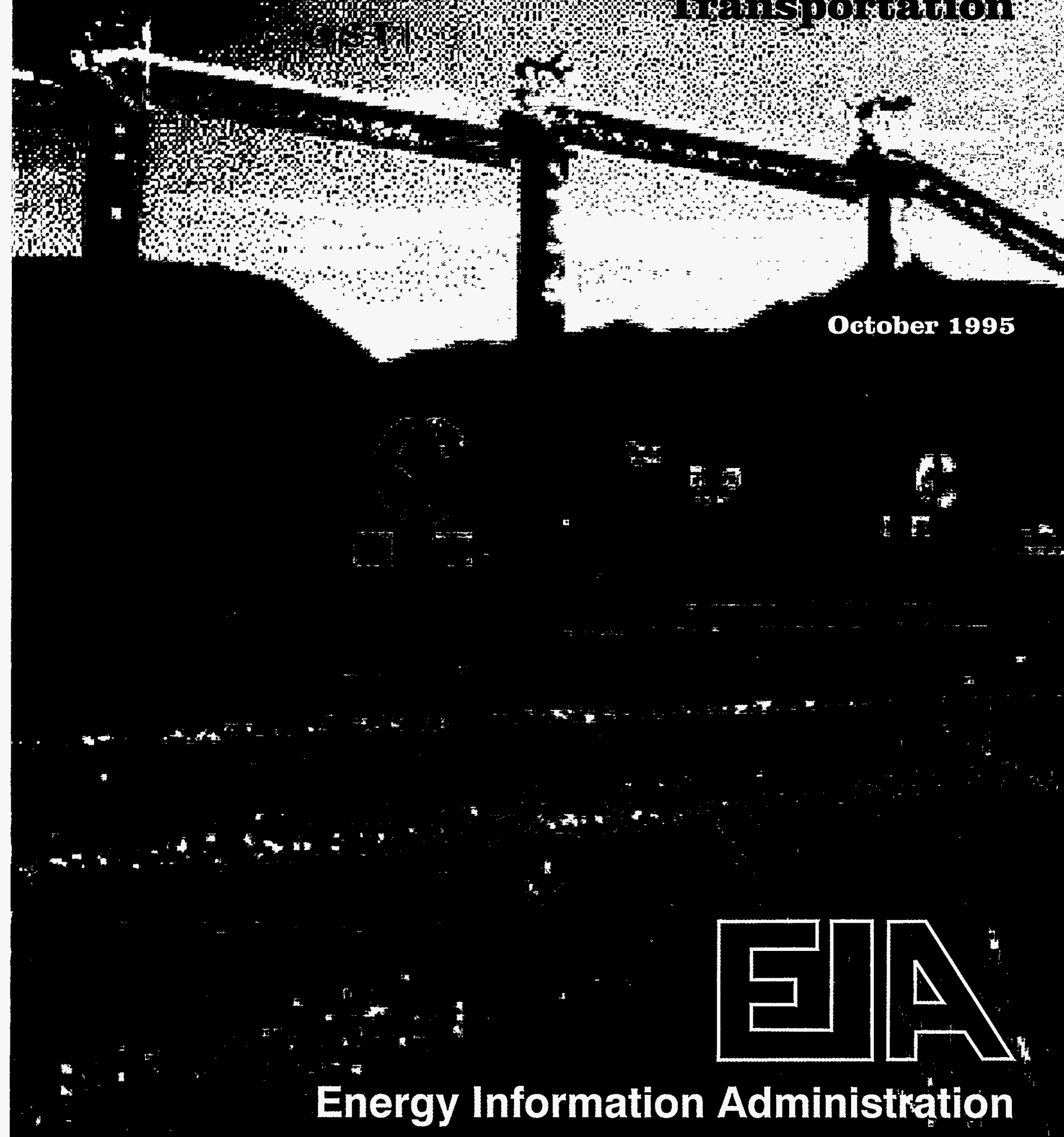

$\mathbf{a}$

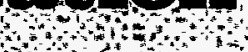

 
This publication and other Energy Information Administration (EIA) publications may be purchased from the Superintendent of Documents, U.S. Government Printing Office.

Telephone orders may be directed to:

Superintendent of Documents

U.S. Government Printing Office

Main Order Desk

(202) $512-1800$

FAX: (202) 512-2250

8 a.m. to $4: 30$ p.m., eastern time, $M-F$

All mail orders should be directed to:

U.S. Government Printing Office

P.O. Box 371954

Pittsburgh, PA 15250-7954

Complimentary subscriptions and single issues are available to certain groups of subscribers, such as public and academic libraries, Federal, State, local and foreign governments, EIA survey respondents, and the media. For further information and for answers to questions on energy statistics, please contact EIA's National Energy Information Center. Address, telephone numbers, and hours are as follows:

National Energy Information Center, EI-231

Energy Information Administration

Forrestal Building, Room 1F-048

Washington, DC 20585

(202)586-8800

Internet E-Mail: INFOCTR@EIA.DOE.GOV

TTY: For people who are deaf or hard

of hearing: (202)586-1181

9 a.m. to 5 p.m., eastern time, M-F

INTERNET ADDRESSES:

E-mail: infoctr@eia.doe.gov

World Wide Web Site://http://www.eia.doe.gov

Gopher Site: gopher://gopher.eia.doe.gov

FTP Site: ftp://ftp.eia.doe.gov

Cover Photo: Rail cars and piles of coal in freight yard.

Released for Printing: October 5, 1995

Printed with soy ink on recycled paper

GPO Stock No.: 061-003-00933-6 
DOE/EIA-0597

Distribution Category UC-950

\title{
Energy Policy Act Transportation Rate Study: Interim Report on Coal Transportation
}

\section{October 1995}

\author{
Energy Information Administration \\ Office of Coal, Nuclear, Electric and Alternate Fuels \\ U.S. Department of Energy \\ Washington, DC 20585
}

This report was prepared by the Energy Information Administration, the independent statistical and analytical agency within the Department of Energy. 


\section{Contacts}

This report, Energy Policy Act Transportation Rate Study: Interim Report on Coal Transportation, was prepared by the Energy Information Administration (EIA), Office of Coal, Nuclear, Electric and Alternate Fuels. General information concerning this report may be obtained from John Geidl (202/254-5570) or Internet jgeidl@eia. doe.gov, Director, Office of Coal, Nuclear, Electric and Alternate Fuels; Robert M. Schnapp (202/254-5392) or Internet rschnapp@eia.doe.gov, Director, Analysis and Systems Division; or Betsy O'Brien (202/254-5490) or
Internet bobrien@eia.doe.gov, Chief, Coal and Electric Analysis Branch.

Specific information regarding the preparation and content of the report should be directed to: B.D. Hong (202/254-5365 or Internet bhong@eia.doe.gov) for overview; Ernest R. Pantos (202/254-5372 or Internet epantos@eia.doe.gov) for analysis; and Thelda McMillian (202/254-5414 or Internet tmcmillian@eia. doe.gov) for data. 


\section{Preface}

This is the second report on coal distribution and transportation rates presented to the U.S. Congress by the Secretary of Energy. Due in October 1995, the report is mandated by Title XIII, Section 1340, "Establishment of Data Base and Study of Transportation Rates," of the Energy Policy Act of 1992 (P.L. 102-486). The first report, Energy Policy Act Transportation Rate Study: Availability of Data and Studies, was submitted to Congress in October 1993. The current report presents an interim analysis of coal transportation rates and distribution patterns using the database developed pursuant to the congressional mandate. A final report is due to Congress in October 2000.

Section 1340 also requires the Energy Information Administration to prepare a study on natural gas transportation rates. That study is being prepared and submitted to Congress in a separate report, Energy Policy Act Transportation Study: Interim Report on Natural Gas Flows and Rates.

Section 1340 of the Energy Policy Act of 1992 states:

(a) Data Base - The Secretary [of Energy] shall review the information currently collected by the Federal Government and shall determine whether information on transportation rates for rail and pipeline transport of domestic coal, oil, and gas during the period of January 1, 1988, through December 31, 1997, is reasonably available. If he determines that such information is not reasonably available, the Secretary shall establish a data base containing, to the maximum extent practicable, information on all such rates. The confidentiality of contract rates shall be preserved. To obtain data pertaining to rail contract rates, the Secretary shall acquire such data in aggregate form only from the Interstate Commerce Commission, under terms and conditions that maintain the confidentiality of such rates.

(b) Study - The Energy Information Administration shall determine the extent to which any agency of the Federal Government is studying the rates and distribution patterns of domestic coal, oil, and gas to determine the impact of the Clean Air Act as amended by the Act entitled "An Act to amend the Clean Air Act to provide for attainment and maintenance of health protective national ambient air quality standards, and for other purposes," enacted November 15, 1990 (Public Law 101-549), and other Federal policies on such rates and distribution patterns. If the Energy Information Administration finds that no such study is underway, or that reports of the results of such study will not be available to the Congress providing the information specified in this subsection and subsection (a) by the dates established in subsection (c), the Energy Information Administration shall initiate such a study.

(c) Reports to Congress - Within one year after the date of enactment of this Act, the Secretary shall report to the Congress on the determination the Energy Information Administration is required to make under subsection (b). Within three years after the date of enactment of this Act, the Secretary shall submit reports on any data base or study developed under this section. Any such reports shall be updated and resubmitted to the Congress within eight years after such date of enactment. If the Energy Information Administration has determined pursuant to subsection (b) that another study or studies will provide all or part of the information called for in this section, the Secretary shall transmit the results of that study by the dates established in this subsection, together with his comments.

(d) Consultation with Other Agencies - The Secretary and the Energy Information Administration shall consult with the Chairmen of the Federal Energy Regulatory Commission and the Interstate Commerce Commission in implementing this section. 



\section{Contents}

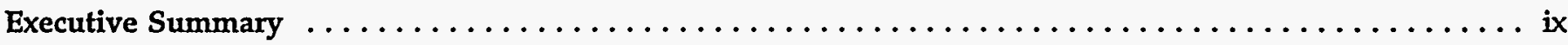

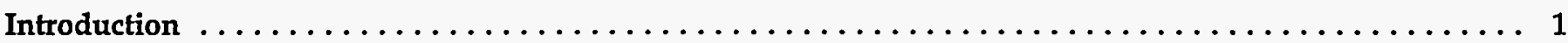

Part I: Impacts of Clean Air Legislation on Coal Distribution and Rail Transportation Rates ......... 3

1. Coal Distribution and Sulfur Content $\ldots \ldots \ldots \ldots \ldots \ldots \ldots \ldots \ldots \ldots \ldots \ldots \ldots \ldots \ldots \ldots \ldots \ldots$

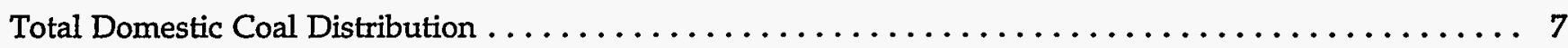

Sulfur Content of Coal Received by Electric Utilities $\ldots \ldots \ldots \ldots \ldots \ldots \ldots \ldots \ldots \ldots \ldots \ldots \ldots \ldots$

2. Railroad Coal Transportation and Transportation Rates $\ldots \ldots \ldots \ldots \ldots \ldots \ldots \ldots \ldots \ldots \ldots \ldots \ldots$

National Trends in Sulfur Content and Transportation Rates for Rail-Shipped Coal . . . . . . . . . 17

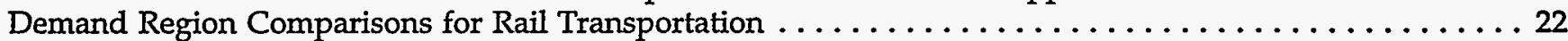

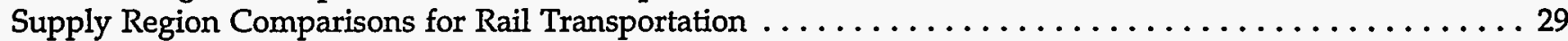

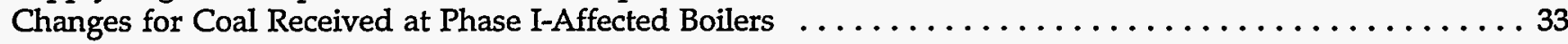

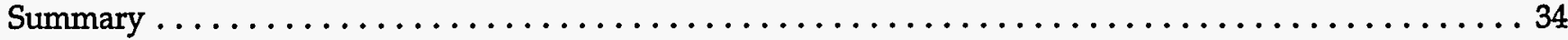

Part II: Electric Utility Contract Coal Transportation Trends, $1979-1993 \ldots \ldots \ldots \ldots \ldots \ldots \ldots$. . . . . . 39

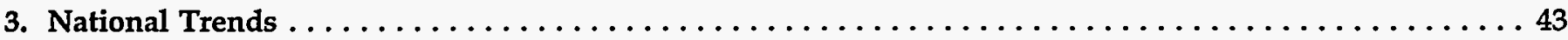

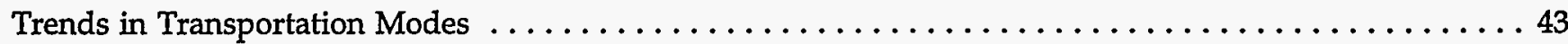

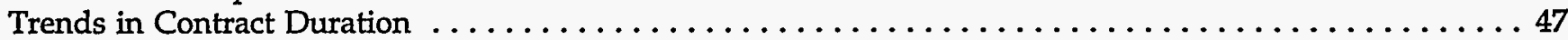

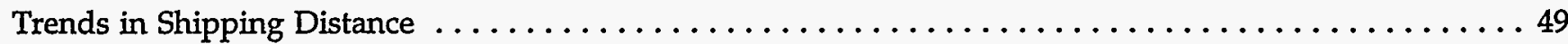

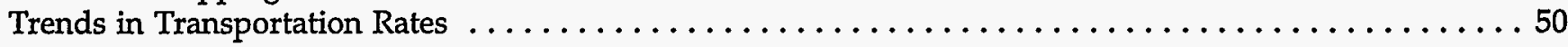

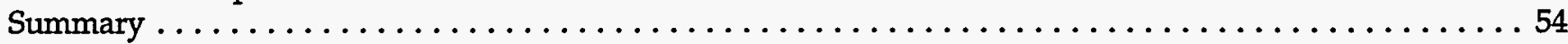

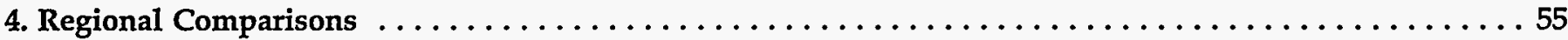

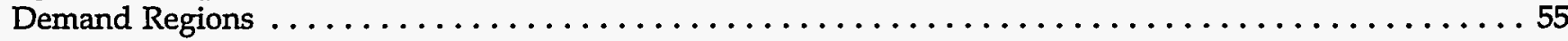

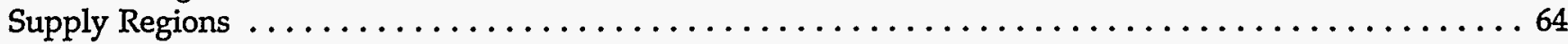

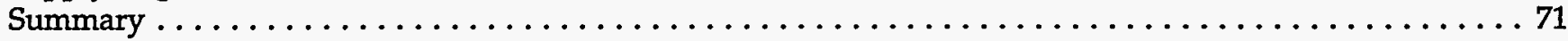

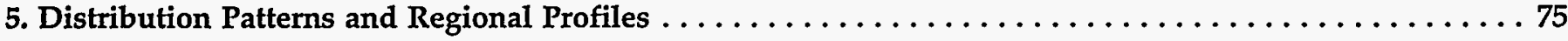

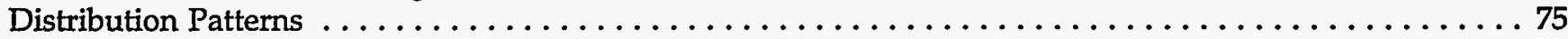

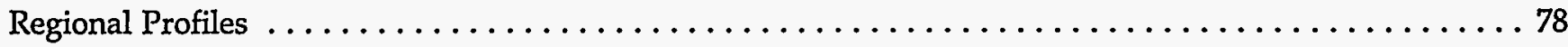

Appendices

A. Detailed Description of the Coal Transportation Rate Data Base $\ldots \ldots \ldots \ldots \ldots \ldots \ldots \ldots \ldots$

B. Characteristics of Coal Supply Contracts Reported on the FERC Form $580 \ldots \ldots \ldots \ldots \ldots \ldots \ldots$

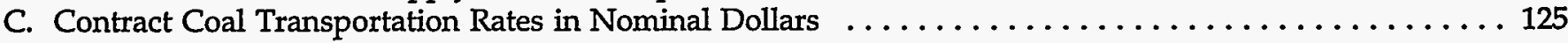


1. Coal Demand Regions (Census Divisions) and Relevant Characteristics, $1993 \ldots \ldots \ldots \ldots$. . . . . 8

2. Domestic Coal Distribution by Demand Region and Transportation Mode, 1988 and 1993 . . . . . . . . . 9

3. Coal Supply Regions and Their Domestic Coal Distribution Shares, $1993 \ldots \ldots \ldots \ldots \ldots \ldots \ldots \ldots$

4. Supply Region Shares of Domestic Coal Distribution, $1988-1993$. . . . . . . . . . . . . . . . . . 12

5. Domestic Coal Distribution by Supply Region and Transportation Mode, 1993 . . . . . . . . . . . . 12

6. Domestic Coal Distribution Between Selected Demand and Supply Regions, 1993 . . . . . . . . . . . . . 13

7. Percentage of Demand Region Coal Receipts Coming from Each Supply Region, 1988 and 1993 . . . . . . 14

8. Average Btu and Sulfur Content of Coal Received by Electric Utilities, 1988 and 1993 . . . . . . . . . . . . 15

9. Rail-Shipped Contract Coal Tonnage by Sulfur Category, $1988-1993 \ldots \ldots \ldots \ldots \ldots \ldots \ldots \ldots$

10. Average Distance of Contract Coal Rail Shipments by Sulfur Category, 1988-1993 . . . . . . . . . . . 18

11. Average Rate per Ton for Contract Coal Rail Shipments by Sulfur Category, 1988-1993 . . . . . . . . . 19

12. Average Rate per Ton for Contract Coal Rail Shipments Between Selected Supply and Demand Regions, 1988 and 1993 . . . . . . . . . . . . . . . . . . . . . . . . . . . . 19

13. Average Rate per Million Btu for Contract Coal Rail Shipments by Sulfur Category, 1988-1993 . . . . . . . 20

14. Transportation Cost as a Percentage of Delivered Price for Contract Coal Rail Shipments

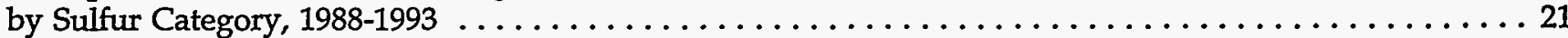

15. Average Rate per Ton-Mile for Contract Coal Rail Shipments by Sulfur Category, 1988-1993 . . . . . . . 21

16. Average Rate per Ton-Mile for Contract Coal Rail Shipments Between Selected Supply and

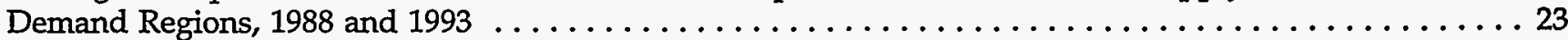

17. Selected Statistics for Contract Coal Shipments by Rail to Electric Utilities in the Middle Atlantic

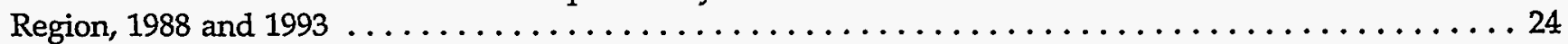

18. Selected Statistics for Contract Coal Shipments by Rail to Electric Utilities in the East North Central

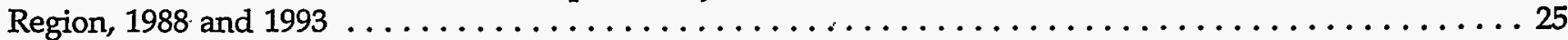

19. Selected Statistics for Contract Coal Shipments by Rail to Electric Utilities in the West North Central

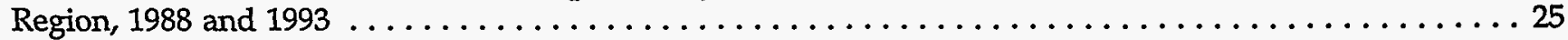

20. Selected Statistics for Contract Coal Shipments by Rail to Electric Utilities in the South Atlantic

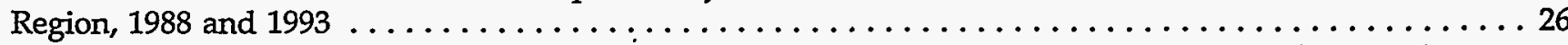

21. Selected Statistics for Contract Coal Shipments by Rail to Electric Utilities in the East South Central

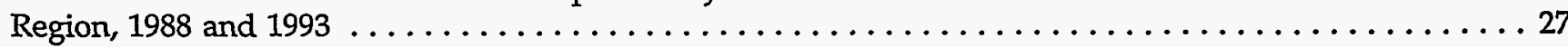

22. Selected Statistics for Contract Coal Shipments by Rail to Electric Utilities in the West South

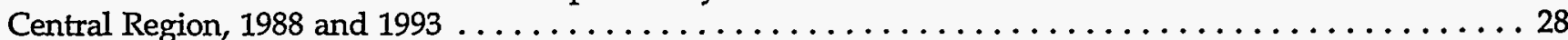

23. Selected Statistics for Contract Coal Shipments by Rail to Electric Utilities in the Mountain Region,

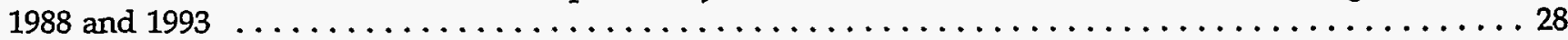

24. Selected Statistics for Utility Contract Coal Shipments by Rail Originating in Northern Appalachia, 1988 and 1993 . . . . . . . . . . . . . . . . . . . . . . . . . . . . . . . . . . . . . . . . . 29

25. Selected Statistics for Utility Contract Coal Shipments by Rail Originating in Central Appalachia,

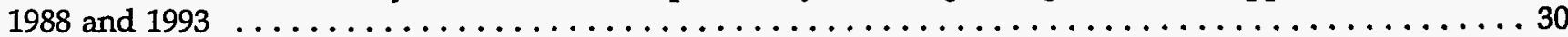

26. Selected Statistics for Utility Contract Coal Shipments by Rail Originating in the Illinois Basin,

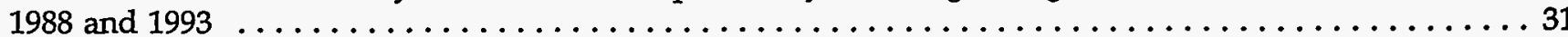

27. Selected Statistics for Utility Contract Coal Shipments by Rail Originating in the Powder River

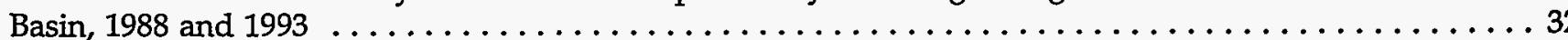

28. Selected Statistics for Utility Contract Coal Shipments by Rail Originating in the Rockies,

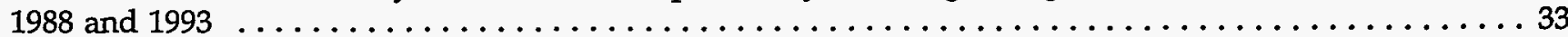

29. Changes in Rail-Shipped Contract Coal Transportation Between 1988 and 1993, Phase I-Affected Boilers

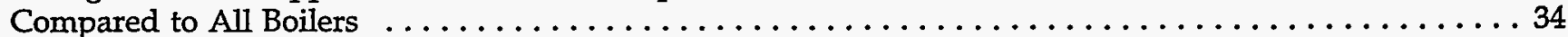

30. Number of Utility Coal Contracts, Contract Tonnage, and Average Tonnage per Contract, 1979-1993 . . . 43

31. Utility Contract Coal Tonnage by Transportation Mode, $1979-1993 \ldots \ldots \ldots \ldots \ldots \ldots \ldots \ldots$. . . . . . . 44

32. Distribution of Contract Coal Tonnage by Contract Duration, $1979-1993 \ldots \ldots \ldots \ldots \ldots \ldots \ldots \ldots$

33. Average Duration of Utility Coal Contracts, $1979-1993 \ldots \ldots \ldots \ldots \ldots \ldots \ldots \ldots \ldots \ldots \ldots \ldots$

34. Average Distance Shipped per Ton for Utility Contract Coal by Transportation Mode, 1979-1993 . . . . . 50

35. Average Utility Contract Coal Transportation Rate per Ton by Transportation Mode, 1979-1993 . . . . . 51 
36. Utility Contract Coal Transportation Cost as a Percentage of Delivered Price, 1979-1993 . . . . . . . . 52

37. Average Utility Contract Coal Transportation Rate per Ton-Mile by Transportation Mode, 1979-1993 . . . 53

38. Utility Contract Coal Tonnage by Demand Region and Transportation Mode, 1979, 1986, and 1993 .... 57

39. Distribution of Utility Contract Coal Tonnage by Contract Duration and Demand Region,

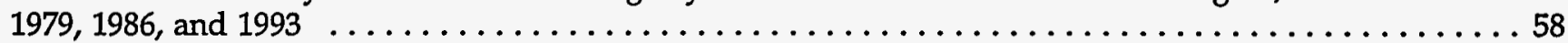

40. Average Utility Contract Duration by Demand Region and Transportation Mode, 1979, 1986, and 1993 .. 59

41. Average Distance Shipped per Ton for Utility Contract Coal by Demand Region and Transportation

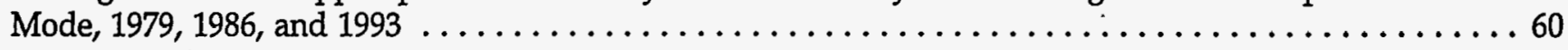

42. Average Utility Contract Coal Transportation Rate per Ton by Demand Region and Transportation

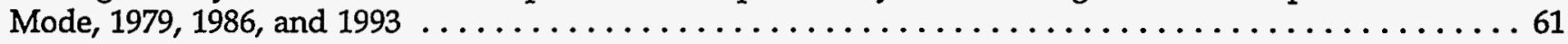

43. Utility Contract Coal Transportation Cost as a Percentage of Delivered Price by Demand Region,

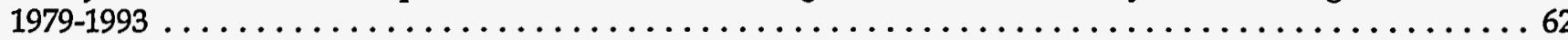

44. Average Utility Contract Coal Transportation Rate Per Ton-Mile by Demand Region and Transportation

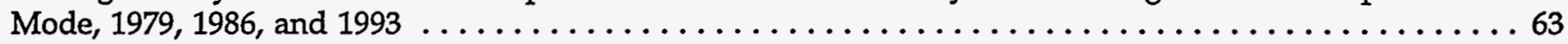

45. Utility Contract Coal Tonnage by Supply Region and Transportation Mode, 1979, 1986, and 1993 . .... 66

46. Utility Contract Coal Tonnage by Contract Duration and Supply Region, 1979, 1986, and 1993 . . . . . . 67

47. Average Utility Contract Duration by Supply Region and Transportation Mode, 1979, 1986, and 1993 ... 68

48. Average Distance Shipped Per Ton for Utility Contract Coal by Supply Region and Transportation

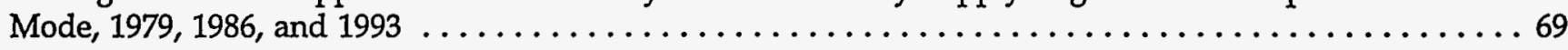

49. Average Utility Contract Coal Transportation Rate Per Ton by Supply Region and Transportation

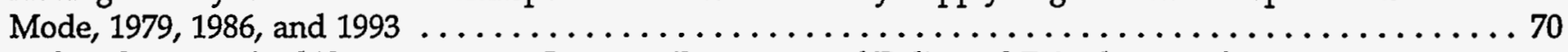

50. Utility Contract Coal Transportation Cost as a Percentage of Delivered Price by Supply Region,

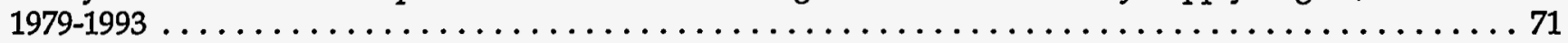

51. Average Utility Contract Coal Transportation Rate per Ton-Mile by Supply Region and Transportation

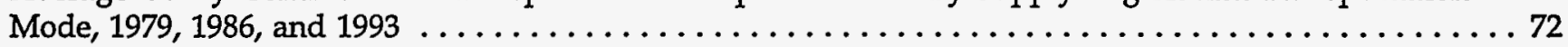

52. Utility Contract Coal Tonnage Shipped Between Supply and Demand Regions, 1979, 1986, and 1993 . ... 76

53. Average Duration of Utility Coal Supply Contracts Between Supply and Demand Regions,

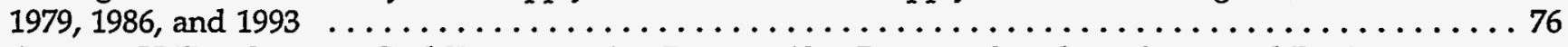

54. Average Utility Contract Coal Transportation Rate per Ton Between Supply and Demand Regions,

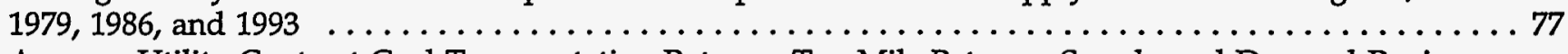

55. Average Utility Contract Coal Transportation Rate per Ton-Mile Between Supply and Demand Regions,

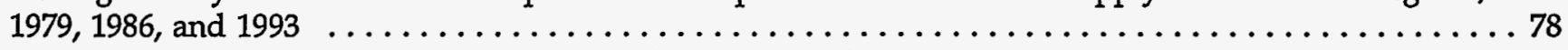

A1. Comparison of FERC Form 580 Contract Coal Tonnage and FERC Form 423 Contract Coal Tonnage,

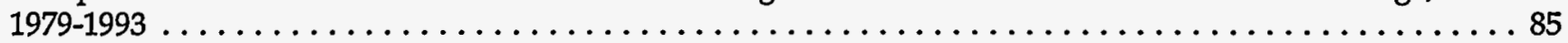

A2. FERC Form 423 Contract and Spot Coal Tonnage Not Covered by FERC Form 580, 1979-1993 . . . . . 85

A3. Data Elements Available for the Calculation of Average Distance Shipped, 1979-1993 . . . . . . . . . 87

A4. Data Elements Available for the Calculation of Average Transportation Rate per Ton, 1979-1993 . . . . 87

A5. Data Elements Available for the Calculation of Average Transportation Rate per Ton-Mile, 1979-1993 . . 88

B1. Utility Contract Coal Shipments in 1993 by Expiration Date . . . . . . . . . . . . . . . 92

C1. Average Rate per Ton for Contract Coal Rail Shipments by Sulfur Category, 1988-1993 . . . . . . . . 127

C2. Average Rate per Million Btu for Contract Coal Rail Shipments by Sulfur Category, 1988-1993 . . . . . . 128

C3. Average Rate per Ton-Mile for Contract Coal Rail Shipments by Sulfur Category, 1988-1993 . . . . . . 128

C4. Average Rate per Ton for Contract Coal Rail Shipments by Demand Region, 1988-1993 . . . . . . . . 128

C5. Average Rate per Million Btu for Contract Coal Rail Shipments by Demand Region, 1988-1993 . . . . . . 129

C6. Average Rate per Ton-Mile for Contract Coal Rail Shipments by Demand Region, 1988-1993 . . . . . . . 129

C7. Average Rate per Ton for Contract Coal Rail Shipments by Supply Region, 1988-1993 . . . . . . . . . . 130

C8. Average Rate per Million Btu for Contract Coal Rail Shipments by Supply Region, 1988-1993 . . . . . . . 130

C9. Average Rate per Ton-Mile for Contract Coal Rail Shipments by Supply Region, 1988-1993 . . . . . . . 131

C10. Average Utility Contract Coal Transportation Rate per Ton by Transportation Mode, 1979-1993 . . . . . 131

C11. Average Utility Contract Coal Transportation Rate per Ton-Mile by Transportation Mode, 1979-1993 . . 132 
C12. Average Utility Contract Coal Transportation Rate per Ton by Demand Region and Transportation Mode, 1979, 1986, and 1993

C13. Average Utility Contract Coal Transportation Rate Per Ton-Mile by Demand Region and Transportation

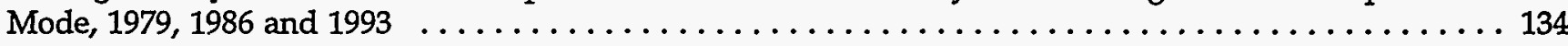

C14. Average Utility Contract Coal Transportation Rate Per Ton by Supply Region and Transportation Mode,

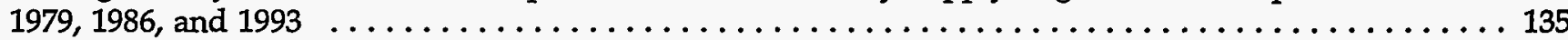

C15. Average Utility Contract Coal Transportation Rate Per Ton-Mile by Supply Region and Transportation

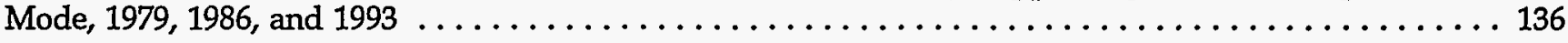

Figures

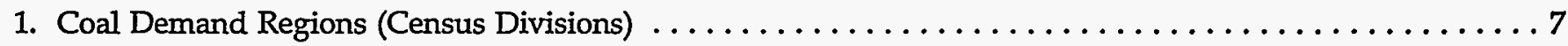

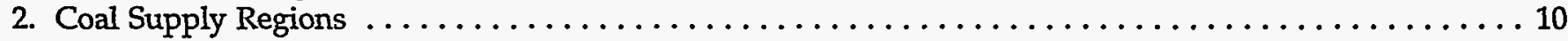

3. Correlation Between Nameplate Generating Capacity Affected by Phase I and Percentage Change in Average Sulfur Content for Seven Coal Demand Regions . . . . . . . . . . . . . . . . . . 16

4. Average Distance, Rate per Ton, and Rate per Ton-Mile for Contract Coal Rail Shipments, 1988-1993 . . . 35

5. Modal Shares of Utility Contract Coal Tonnage, 1979, 1986, and 1993 . . . . . . . . . . . . . . 44

6. Average Distance Shipped per Ton for Utility Contract Coal Tonnage by Transportation Mode,

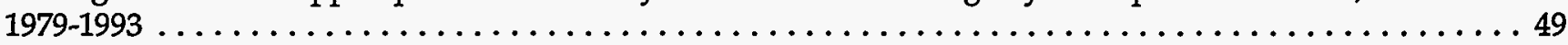

7. Average Utility Contract Coal Transportation Rate per Ton by Transportation Mode, 1979-1993 . . . . . . 51

8. Average Utility Contract Coal Transportation Cost as a Percentage of Delivered Price, 1979-1993 . . . . . 53

9. Demand Regions . . . . . . . . . . . . . . . . . . . . . . . . . . . . . . 56

10. Average Utility Contract Coal Transportation Rate per Ton by Demand Region, 1979, 1986, and 1993 . . . 62

11. Average Utility Contract Coal Transportation Rate per Ton-Mile by Demand Region, 1979, 1986,

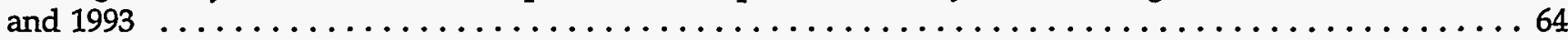

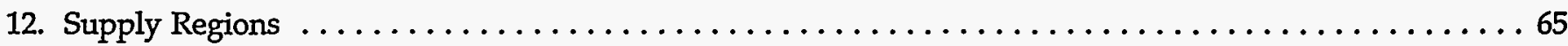

13. Average Utility Contract Coal Transportation Rate per Ton by Supply Region, 1979, 1986, and 1993 . . . . 70

14. Average Utility Contract Coal Transportation Rate per Ton-Mile by Supply Region, 1979, 1986, and 1993 . 72 


\section{Executive Summary}

\section{Impacts of the Clean Air Act Amendments of 1990}

The primary purpose of this report is to examine changes in domestic coal distribution and railroad coal transportation rates since enactment of the Clean Air Act Amendments of 1990 (CAAA90). From 1988 through 1993, the demand for low-sulfur coal increased, as the 1995 deadline for compliance with Phase I of CAAA90 approached. The shift toward low-sulfur coal came sooner than had been generally expected because many electric utilities switched early from high-sulfur coal to "compliance" (very low-sulfur) coal. They did so to accumulate emissions allowances that could be used to meet the stricter Phase $\Pi$ requirements. Thus, the demand for compliance coal increased the most.

Coal from the Powder River Basin (mainly Wyoming), the premier source of compliance coal in the West and nationally, accounted for 28 percent of the total coal tonnage distributed domestically in 1993, compared to 24 percent in 1988. The share held by Central Appalachia, the primary source of compliance coal and other low-sulfur coal in the East, rose only slightly, from 23 percent to 24 percent. Minemouth coal prices were falling faster for Powder River Basin coal than for coal from any other major supply region, widening the minemouth price advantage of Powder River Basin coal over Central Appalachian compliance coal. At the same time, railroad rates for transporting coal from the Powder River Basin were falling rapidly. As a result of those factors, major electric utilities in the Midwest determined Powder River Basin coal to be more economical for them than closer Central Appalachian coal.

Between 1988 and 1993, demand for high-sulfur coal declined substantially, affecting the high-sulfur coal supply regions of Northern Appalachia and the Illinois Basin. The Tllinois Basin's share of total domestically distributed coal fell from 15 percent in 1988 to 12 percent in 1993, as it lost markets in the Midwest to compliance coal from the Powder River Basin. Northern Appalachia supplied 14 percent of the coal distributed domestically in 1993, down from 17 percent in 1988. It lost market share primarily in the Middle Atlantic and South Atlantic regions, where utilities shifted to lowsulfur coal from Central Appalachia.

Nationwide, the average sulfur content of the coal received by electric utilities fell by 13 percent between 1988 and 1993. Generally, the greater the region's generating capacity affected by Phase I, the greater was the decline in the average sulfur content of the coal burned by its utilities. One exception was the West North Central Region. Although only 8 percent of its generating capacity was affected by Phase I, its utilities shifted so much from medium-sulfur and high-sulfur coals to Powder River Basin coal that the average sulfur content dropped by an extraordinary 36 percent.

The average shipping distance for contract coal ${ }^{1}$ transported to electric utilities by rail went up by 11 percent between 1988 and 1993, from 604 miles to 671 miles. This rise was due to the increasing amount of coal shipped from the Powder River Basin (typically associated with long hauls to utilities in the Midwest and Texas) and the decreasing amount of coal shipped from the Illinois Basin (typically associated with short hauls). Largely because of the high capital costs of flue gas scrubbers and falling western coal transportation rates, many utilities decided to switch to low-sulfur western coals (sometimes blended with higher-sulfur coals) rather than install scrubbers and burn nearby highsulfur coal.

CAAA90 and other Federal legislation have not caused coal transportation rates to increase. Even though the coal was shipped greater distances, the average transportation cost for contract coal shipped by railroads fell by 19 percent, from $\$ 11.08$ per ton in 1988 to $\$ 8.93$ in 1993..$^{2}$ Generally, intense competition in the coal and

\footnotetext{
"Contract coal" refers to the coal shipped under electric utility contracts included in the Energy Information Administration's Coal Transportation Rate Data Base (CTRDB), which primarily includes data reported by utilities on the Federal Energy Regulatory Commission's FERC Form 580. A contract is a purchase agreement of 1 year's duration or longer.

${ }^{2}$ The average rate per ton-mile (i.e., the average rate per ton, per mile shipped) fell by 28 percent between 1988 and 1993 . In this report, tonnage is measured in short tons (2,000 pounds) and prices are in constant 1987 dollars. See Appendix C for the implicit GDP price deflators used to convert nominal dollars to constant dollars.
} 
railroad industries resulted in strong pressure to reduce costs. Technological advancements and organizational improvements in the railroad industry led to greater efficiency and productivity, allowing railroads to cut their rates. However, the average transportation cost fell by less for the coal shipped to Phase I-affected generating units, because the average distance increased more for shipments to those plants.

The changes in coal distribution were most pronounced for the electric utilities that were directly affected by Phase I of CAAA90. Between 1988 and 1993, receipts of rail-shipped contract compliance coal at Phase I-affected boilers increased by 130 percent (from about 6 million tons to 13 million tons), while the increase for all boilers was only 27 percent, going from 107 million to 135 million tons (Figure ES1). High-sulfur coal receipts declined by 52 percent (from 33 million to 16 million tons) for Phase I-affected boilers, compared to a 33percent decline (from 42 million to 28 million tons) for all boilers.

The average shipping distance for contract coal delivered by rail to Phase I-affected boilers increased by 77 percent (from 213 miles to 377 miles), compared to an 11-percent increase (from 604 miles to 671 miles) for all units. Because of the greater increase in shipping distance, the average transportation cost for the coal delivered to Phase I-affected boilers fell by only 4 percent (from $\$ 6.32$ to $\$ 6.07$ per ton), compared to a $19-$ percent drop (from $\$ 11.08$ to $\$ 8.93$ per ton) for all boilers.

\section{Coal Transportation Trends}

The secondary purpose of this report is to provide a broad view of contract coal transportation trends, covering the various coal transportation modes during the period from 1979 through $1993 .{ }^{3}$ Railroads hauled 58 percent of the contract coal delivered to electric utilities in 1993, while barges transported 11 percent of the total. Truck hauls and multimodal (principally rail/barge) movements each accounted for 9 percent of the total. Most of the remaining coal was moved from mine to power plant by conveyor. Between 1979 and 1993, railroads lost a small part of their market share to barges and trucks.

As coal markets expanded between 1979 and 1993, primarily because of increased shipments of Powder River

\section{Figure ES1. Changes in Utility Contract Coal Transportation, 1988-1993 (Percent Change)}

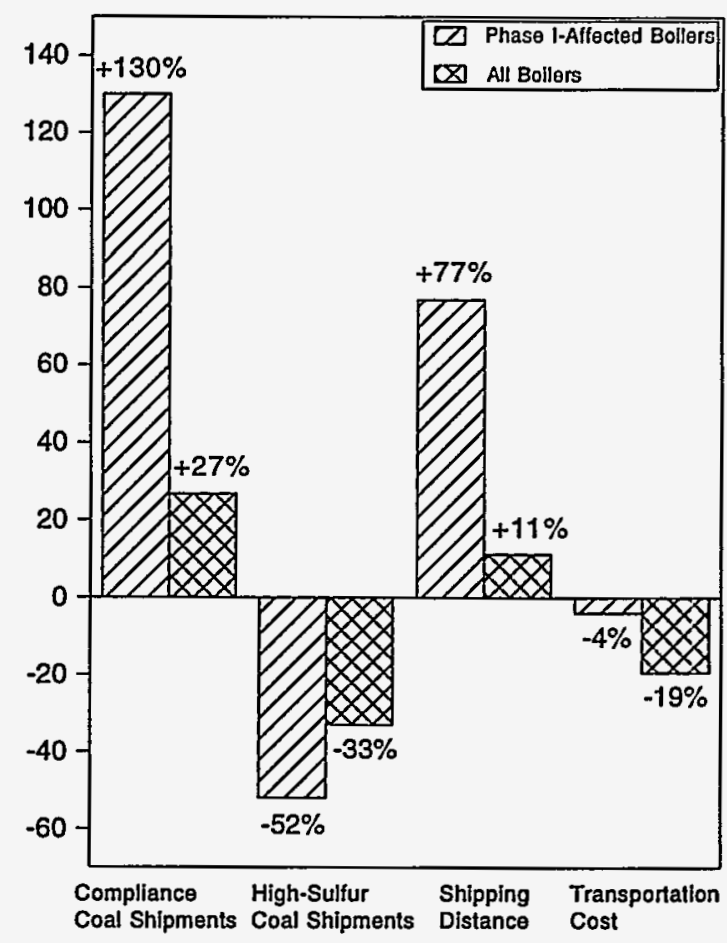

Note: Based on railroad shipments of contract coal to electric utilities.

Source: Energy Information Administration, Coal Transportation Rate Data Base.

Basin coal to Midwestern power plants, the average shipping distance for contract coal rose by 32 percent, from 438 miles to 576 miles. The average distance for multimodal (principally combined rail/barge) movements increased by 40 percent, from 571 miles to 1,054 miles.

For all transportation modes combined, the average transportation cost fell by 23 percent between 1979 and 1993 , from $\$ 10.11$ to $\$ 7.83$ per ton. ${ }^{4}$ Generally, transportation rates went down for every transportation mode (Figure ES2), as efficiency increased in the barge, trucking, and railroad industries. The efficiency gains were spurred by conditions of excess capacity and intense competition. Inefficient operations were closed, personnel levels were trimmed, and improvements were made in equipment, communications, and

\footnotetext{
${ }^{3}$ This discussion updates a previous Energy Information Administration report on utility contract coal transportation that covered the 1979 through 1987 period. See Trends in Contract Coal Transportation, 1979-1987, DOE/EIA-0549 (Washington, DC, September 1991).

'The average rate per ton-mile dropped by 41 percent.
} 
organization. Nevertheless, transportation cost represented 31 percent of the average delivered price of contract coal in 1993, up from 25 percent in 1979. The transportation cost component of the average delivered price increased because minemouth coal prices fell even faster than transportation costs.

The three major U.S. coal supply regions are Appalachia, the Interior Region, and the Western Region. By 1993, the Western Region was supplying 51 percent of the contract coal delivered to electric utilities, compared to 35 percent in 1979. During the same 14-year period, the Interior Region's share dropped from 22 percent to 12 percent, while Appalachia's portion declined from 43 percent to 37 percent.
Railroads moved more than half of the coal shipped from each of these supply regions. Barges were the second-largest coal transporters for shipments from Appalachia and the Interior Region, whereas conveyors were the second-most important movers of coal from Western Region mines.

For all transportation modes combined, the average transportation cost for contract coal shipments declined in all three regions between 1979 and 1993. In 1993, the average cost was $\$ 9.76$ per ton for Western coal, $\$ 6.91$ per ton for Appalachian coal, and $\$ 3.07$ per ton for coal from the Interior Region. These cost differences primarily reflected differences in average shipping distance.

Figure ES2. Average Utility Contract Coal Transportation Rate per Ton by Transportation Mode, 1979-1993

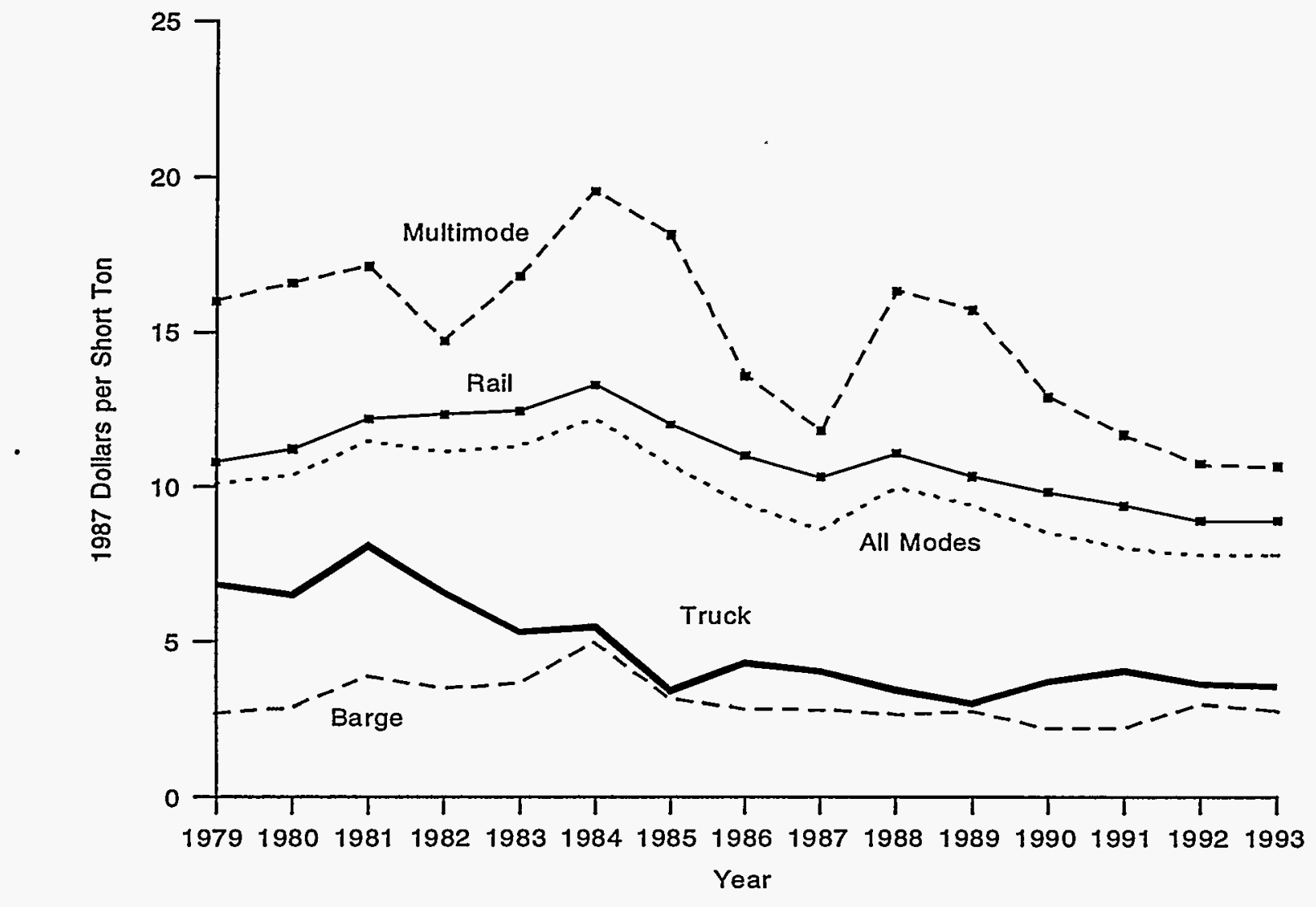

Source: Energy Information Administration, Coal Transportation Rate Data Base. 


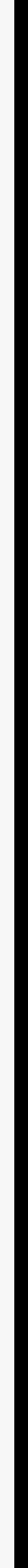




\section{Introduction}

This report presents an interim analysis of changes in coal transportation rates and distribution patterns using the Coal Transportation Rate Data Base (CTRDB) maintained by the Energy Information Administration (EIA), pursuant to congressional mandate. The CTRDB is a compilation of data drawn primarily from a survey conducted by the Federal Energy Regulatory Commission (FERC) using Form 580, "Interrogatory on Fuel and Energy Purchase Practices." FERC Form 580 collects, among many other data elements, information on the cost, quantity, quality, and origin of coal purchased under contract by investor-owned, interstate electric utility plants, and on the transportation rate, mode, and distance of the contract coal shipments. FERC began collecting Form 580 data in 1979 to meet requirements under the Public Utility Regulatory Policies Act of 1978 (P.L. 95-617).

The FERC Form 580 survey uniquely provides data needed for utility coal transportation analysis. However, it should be noted that the survey's coverage is substantially smaller than, for example, that of FERC Form 423, "Monthly Report of Cost and Quality of Fuels for Electric Plants," which includes both contract and spot coal shipments to all electric utilities whether they are investor-owned, publicly owned, interstate, or intrastate. Hence, coal transportation rates based on the FERC Form 580 survey present "representative" rather than actual rates for all utility coals.

The CTRDB currently contains FERC Form 580 data for 1979 through 1993. Data for 1993 are the most recent data available. The CTRDB is limited to public use data; these data do not identify the minemouth coal prices and the transportation costs separately for respondents that request confidentiality. Section 1340(b) of the Energy Policy Act of 1992, however, specifically requires EIA to study the impact of the Clean Air Act of 1990 (Public Law 101-549) and other Federal policies on the railroad rates and distribution patterns of domestic coal over the period from 1988 through 1997. To meet this requirement, EIA obtained the confidential cost data from FERC for the years 1988 through 1993 and analyzed them as well as the public use data for the study presented in this report.

Thus, the availability of data and the purposes of this study dictated the scope and detail of the analysis presented in this report as well as the organization of the report. Analyzing data for 1988 through 1993, Part I of this report discusses changes that have taken place in coal distribution (Chapter 1) and rail transportation costs (Chapter 2) since 1988. Using data collected on Form EIA-6, "Coal Distribution Report" (an EIA survey), Chapter 1 captures changes in the distribution patterns of all domestic coal, including coal delivered to industrial, commercial, and other consumers. Using the CTRDB, Chapter 2 analyzes changes in the costs of the contract coal delivered by rail to electric utilities.

Although limited to a 5-year period, the data elements used in Part I are broad in scope and refined in detail, and the confidential cost data are included in the data base, improving the data coverage. Regions are narrowly defined, delineating 11 supply regions and 9 demand regions. As a result, coal distribution patterns, for example, can be focused on high-sulfur and lowsulfur coal regions. The data base thus allows trends in rail coal distribution patterns and transportation rates to be examined in sufficient detail to capture the impact of the Clean Air Act Amendments of 1990.

Analyzing data in the CTRDB for 1979 through 1993, Part II of this report presents a broader but longer-term view of contract coal transportation than Part I. Chapter 3 begins Part $I I$ by presenting national trends in contract coal tonnage, transportation distances, and transportation rates by mode (rail, barge, multimode, truck, and other modes) during the 1979-1993 period. Chapter 4 in Part II captures regional trends in coal contract tonnage, transportation distance, and rates by mode during the same period, in four broad demand (consumption) regions and three broad supply (coalproducing) regions. Chapter 5 examines changes in coal distribution patterns between the same broad coal supply and demand regions over the 1979-1993 period. The analysis presented in these chapters essentially provides more recent data to update Trends in Contract Coal Transportation, 1979-1987, prepared and published by EIA in 1991.

Finally, three appendices provide additional information on the topic: a detailed description of the CTRDB, including a comparison of FERC Form 580 with FERC Form 423 in coverage (Appendix A); a table showing some of the key data items on individual coal supply contracts, such as coal quality, coal prices, and transportation costs, organized by contract expiration date, 
electric utility company, and power plant (Appendix B); and a presentation in nominal dollars of transportation rates (Appendix C), which are expressed in 1987 constant dollars throughout the main body of the report.

The data base, which currently contains data from 1979 through 1993, will be updated with 1994 and 1995 data sometime in the early part of 1997, and the data base including 1996 and 1997 data will be available in the early part of 1999, after FERC conducts the next two biennial Form 580 surveys. As required by the Energy Policy Act of 1992, a final report assessing the effects of
Federal laws and policies on the transportation rates and distribution patterns of domestic coal will be submitted to Congress in October 2000. The final report will update and focus on Part I of the current interim report, analyzing additional FERC Form 580 data for 1994 through 1997.

Selected data for 1993 from the CTRDB as well as the report are available electronically on Internet. They may be accessed from EIA's FTP Server by connecting to FTP.EIA.DOE.GOV and from the EIA Home Page by connecting to WWW.EIA.DOE.GOV. 


\section{Part I}

\section{Impacts of Clean Air Legislation on Coal Distribution and Rail Transportation Rates}




\section{Impacts of Clean Air Legislation on Coal Distribution and Rail Transportation Rates}

Part I of this report represents the first stage of an analysis of the impacts of the Clean Air Act Amendments of 1990 (CAAA90) and other Federal policies on the domestic distribution of U.S. coal and on railroad coal transportation rates. Such an analysis is mandated by Section 1340(c) of the Energy Policy Act of 1992.

Title IV of CAAA90 restricts sulfur dioxide emissions from all electric power plants to 8.9 million tons per year by the year 2000-about 10 million tons below the 1980 level. This reduction is to take place in two phases. By January 1, 1995 (the beginning of Phase I), the 110 largest sulfur-emitting power plants must reduce their emissions to an average of 2.5 pounds of sulfur dioxide per million Btu of heat input or less. By January 1, 2000 (the start of Phase II), virtually all electric power producers must reduce their emissions to no more than 1.2 pounds of sulfur dioxide per million Btu. Utilities may reduce their emissions by any combination of several methods, including switching to low-sulfur coal, blending low-sulfur coal with other coals, switching to alternative fuels (particularly natural gas), installing flue gas desulfurization equipment (scrubbers), and retiring generating units. Alternatively, they may obtain additional emissions allowances from other utilities, from coal companies that package allowances with the coal they supply, or from firms that buy, sell, or trade allowances.

According to a recent Energy Information Administration report, based on information provided to the Environmental Protection Agency by electric utilities in late 1993, fuel switching and/or blending will be the compliance method for 162 (62 percent) of the 261 generating units affected by Phase $I{ }^{1}{ }^{1}$ This finding implies that coal sources will change significantly, with increased coal shipments coming from regions with low-sulfur coal resources. Given the location of lowsulfur coal reserves in relation to high-demand regions, another implication is that the coal will have to be shipped increased distances from the mine to the utility plant. Railroad track and equipment will have to be upgraded and expanded. Thus, if technological and competitive conditions remain constant, it is reasonable to expect coal transportation costs to increase, an expectation that will be compared with the findings of this analysis.

The purpose of Part $I$ is to discern changes that have taken place in coal distribution patterns and rail transportation costs since 1988 . The results reflect not only the initial effects of CAAA90, but also the impact of earlier Federal and State clean air legislation. The early effects of the Phase $I I$ requirements are even captured to some extent, because some utilities have decided to reduce their emissions more than is necessary for Phase I in order to accumulate emissions allowances for use in meeting the more stringent limits of Phase II.

This preliminary analysis is based upon an examination of domestic coal distribution patterns and railroad coal transportation rates over the period from 1988 through 1993. The data elements used in the analysis are broader in scope and more refined in detail than the data used in Part $I$ of this report. Part I examines narrower (and more) demand and supply regions, compared to Part $\Pi$, and it distinguishes various sulfur content categories. The analysis focuses on changes in the sources, average sulfur content, and transportation cost of the coal used by electric utilities, which are by far the Nation's largest coal consumers. First, however, an overview of total domestic coal distribution between 1988 and 1993 is presented.

\footnotetext{
'Energy Information Administration, Electric Utility Phase I Acid Rain Compliance Strategies for the Clean Air Act Amendments of 1990, DOE/EIA-0582 (Washington, DC, March 1994), p. x.
} 


\section{Coal Distribution and Sulfur Content}

\section{Total Domestic Coal Distribution}

\section{Coal Demand Regions}

The U.S. Census Divisions serve as coal demand regions for purposes of this analysis (Figure 1). The

Figure 1. Coal Demand Regions (Census Divisions) importance of coal and Phase I of CAAA90 to electric utilities differs among these regions, and the regions receive widely different shares of total U.S. coal shipments (Table 1). Since coal and Phase I have little significance for two of the regions (New England and Pacific), only seven of the nine Census Divisions are considered in the following analysis.

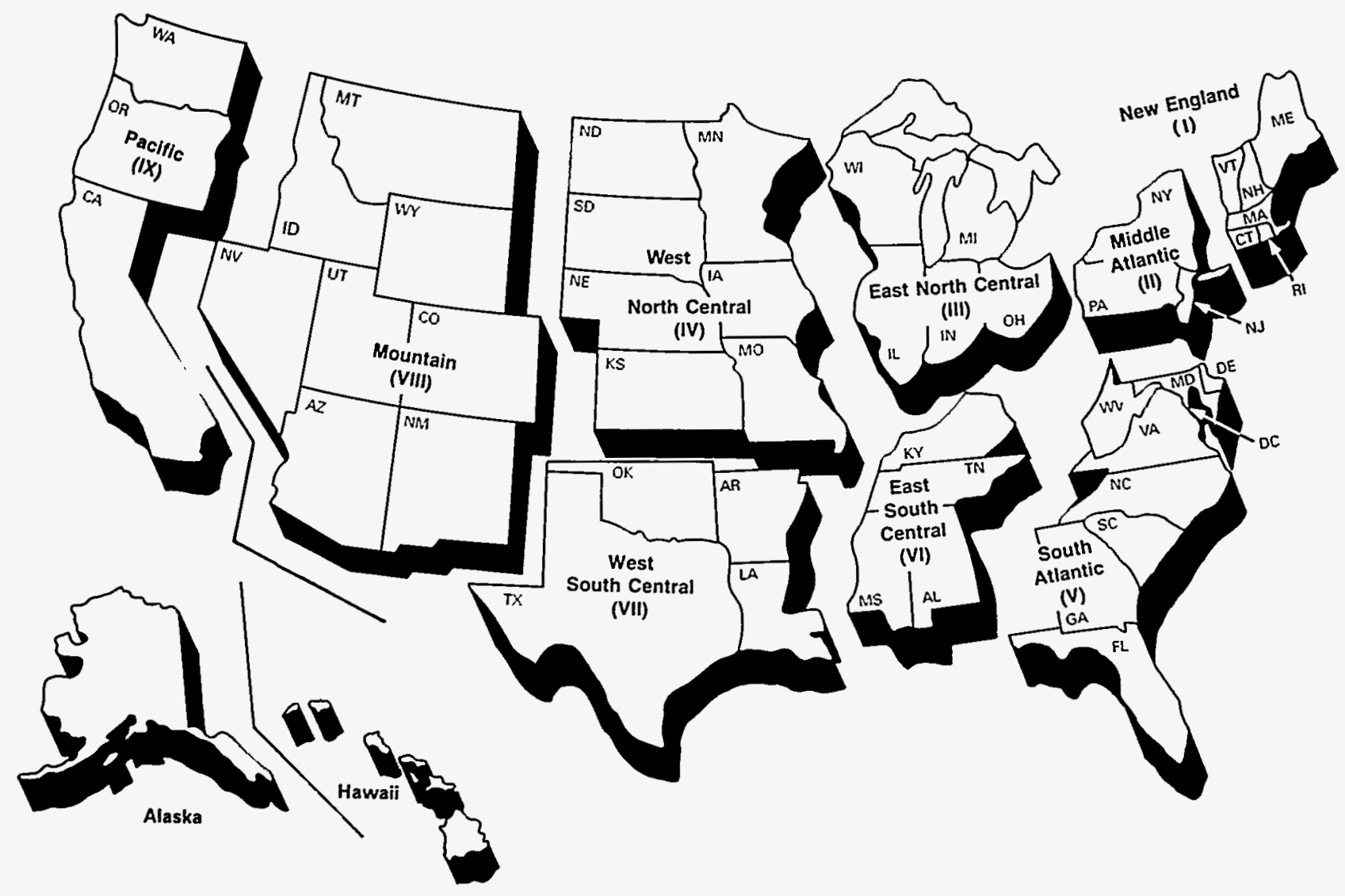

Source: Energy Information Administration, U.S. Department of Energy. 
Table 1. Coal Demand Regions (Census Divisions) and Relevant Characteristics, 1993

\begin{tabular}{|c|c|c|c|c|c|}
\hline \multirow[b]{2}{*}{ Region } & \multicolumn{2}{|c|}{ Coal Receipts } & \multirow{2}{*}{$\begin{array}{l}\text { Coal-fired } \\
\text { Generating } \\
\text { Capability } \\
\text { (gigawatts) }\end{array}$} & \multirow{2}{*}{$\begin{array}{l}\text { Coal-fired as } \\
\text { Percent of } \\
\text { Total } \\
\text { Generating } \\
\text { Capability }\end{array}$} & \multirow{2}{*}{$\begin{array}{l}\text { Nameplate } \\
\text { Capacity } \\
\text { Affected } \\
\text { by Phase I } \\
\text { (gigawatts) }\end{array}$} \\
\hline & $\begin{array}{l}\text { Thousand } \\
\text { Short Tons }\end{array}$ & $\begin{array}{l}\text { Percent of } \\
\text { U.S. Total }\end{array}$ & & & \\
\hline New England & 4,141 & 0.5 & 2.6 & 11.8 & 0.5 \\
\hline Middle Atlantic $\ldots \ldots \ldots \ldots$ & 64,421 & 7.3 & 23.0 & 28.8 & 10.4 \\
\hline East North Central & 196,343 & 22.2 & 77.0 & 67.4 & 34.9 \\
\hline West North Central ........ & 116,337 & 13.2 & 34.9 & 63.8 & 7.9 \\
\hline South Atlantic . .......... & 141,701 & 16.0 & 64.6 & 47.9 & 20.5 \\
\hline East South Central ........ & 97,057 & 11.0 & 36.6 & 62.5 & 15.2 \\
\hline West South Central . . . . . . . & 139,664 & 15.8 & 31.4 & 30.4 & 0 \\
\hline Mountain $\ldots \ldots \ldots \ldots \ldots$ & 109,200 & 12.4 & 28.8 & 57.7 & 0 \\
\hline Pacific $\ldots \ldots \ldots \ldots \ldots$ & 10,791 & 1.2 & 2.0 & 2.4 & 0 \\
\hline U.S. Total & 883,934 & 100.0 & 300.8 & 43.0 & 89.0 \\
\hline
\end{tabular}

Note: Generating capability refers to net summer capability. U.S. total coal receipts include those for which destination is unknown. Components may not add to totals because of independent rounding.

Sources: Coal receipts: Energy Information Administration, Coal Industry Annual 1993, DOE/EIA-0584(93) (Washington, DC, December 1994), pp. 101-102. Generating capability: Energy Information Administration, Electric Power Annual 1993, DOE/EIA-0348(93) Washington, DC, December 1994), pp. 24-25. Nameplate capacity: Energy Information Administration, Acid Rain Compliance Strategies for the Clean Air Act Amendments of 1990, DOE/EIA-0582 (Washington, DC, March 1994), p. 3.

The pattern of coal distribution to the various demand regions remained quite stable over the 1988 through 1993 period. The most significant change was a 10percent increase in the proportion of coal shipped to consumers in the East South Central Region. Most of this change occurred in 1993, when the region's share of total coal receipts rose from 10 to 11 percent. The shift reflected increases in electric utility coal receipts in Alabama, Mississippi, and Tennessee, which resulted from growing electricity demand and the use of coalfired generation to offset a substantial decrease in nuclear generation. ${ }^{2}$

Railroads are the leading coal transporters in all of the demand regions, accounting in 1993 for more than twothirds of the shipments to consumers in the West North Central, South Atlantic, and West South Central regions, and for more than half of the shipments to the East North Central and Mountain regions in 1993 (Table 2). Between 1988 and 1993, rail transportation gained market share in the Middle Atlantic Region (primarily because of a substantial decline in conveyor shipments to Pennsylvania power plants) and in the Mountain Region, where rail shipments increased by 28 percent while coal slurry pipeline and conveyor shipments fell by 26 percent.

Rail is the dominant transportation mode for coal shipped to the two coal demand regions that are affected most in Phase I of CAAA90. In 1993, railroads accounted for 58 percent of the coal shipped to the East North Central Region (roughly representing the Midwest) and for 71 percent of the coal shipped to the South Atlantic Region (extending from Delaware, Maryland, and West Virginia to Florida).

Barge transportation accounted for more than 20 percent of the shipments in only two of the demand regions. Its significance was greatest in the East South Central Region, which is richly endowed with inland waterways. Barge's share of the region's coal transportation rose from 33 percent in 1988 to 36 percent in 1993, nearly equaling rail's share. In the Middle Atlantic Region, barge movements accounted for 24 percent of the coal delivered to consumers in 1993. This was a decline from 26 percent in 1988, as trucks gained market share over the 5-year period.

\footnotetext{
2Energy Information Administration, Cost and Quality of Fuels for Electric Utility Plants 1993, DOE/EIA-0191(93) (Washington, DC, July 1994), p. 11.
} 
Table 2. Domestic Coal Distribution by Demand Region and Transportation Mode, 1988 and 1993

\begin{tabular}{|c|c|c|c|c|c|}
\hline \multirow[b]{2}{*}{$\begin{array}{c}\text { Demand Region/ } \\
\text { Year }\end{array}$} & \multirow{2}{*}{$\begin{array}{c}\text { Total } \\
\text { Tonnage } \\
\text { (thousand short } \\
\text { tons) }\end{array}$} & \multicolumn{4}{|c|}{ Percent of Total } \\
\hline & & Rail & Barge $^{a}$ & Truck & Other ${ }^{b}$ \\
\hline \multicolumn{6}{|l|}{ Middle Atlantic } \\
\hline $1988 \ldots \ldots \ldots \ldots \ldots \ldots$ & 70,253 & 37.7 & 25.8 & 21.6 & 14.9 \\
\hline $1993 \ldots \ldots \ldots \ldots \ldots \ldots$ & 64,421 & 43.3 & 23.9 & 25.9 & 6.9 \\
\hline \multicolumn{6}{|l|}{ East North Central } \\
\hline $1988 \ldots \ldots \ldots \ldots \ldots \ldots$ & 193,389 & 58.0 & 18.1 & 12.5 & 11.4 \\
\hline $1993 \ldots \ldots \ldots \ldots \ldots \ldots$ & 196,343 & 58.3 & 18.2 & 13.9 & 9.6 \\
\hline \multicolumn{6}{|l|}{ West North Central } \\
\hline $1988 \ldots \ldots \ldots \ldots \ldots \ldots$ & 112,365 & 65.0 & 6.3 & 6.6 & 22.0 \\
\hline $1993 \ldots \ldots \ldots \ldots \ldots$ & 116,337 & 67.0 & 4.8 & 5.8 & 22.4 \\
\hline \multicolumn{6}{|l|}{ South Atlantic } \\
\hline $1988 \ldots \ldots \ldots \ldots \ldots$ & 141,606 & 71.2 & 15.3 & 5.4 & 8.1 \\
\hline $1993 \ldots \ldots \ldots \ldots \ldots \ldots$ & 141,701 & 71.4 & 16.8 & 5.5 & 6.3 \\
\hline \multicolumn{6}{|l|}{ East South Central } \\
\hline $1988 \ldots \ldots \ldots \ldots \ldots \ldots$ & 85,737 & 40.2 & 32.9 & 21.5 & 5.3 \\
\hline $1993 \ldots \ldots \ldots \ldots \ldots \ldots$ & 97,057 & 39.9 & 36.2 & 22.1 & 1.8 \\
\hline \multicolumn{6}{|l|}{ West South Central } \\
\hline $1988 \ldots \ldots \ldots \ldots \ldots \ldots$ & 126,542 & 69.4 & 4.2 & 10.5 & 15.9 \\
\hline $1993 \ldots \ldots \ldots \ldots \ldots \ldots$ & 139,664 & 68.8 & 4.8 & 12.0 & 14.4 \\
\hline \multicolumn{6}{|l|}{ Mountain } \\
\hline $1988 \ldots \ldots \ldots \ldots \ldots \ldots$ & 104,271 & 48.2 & 0 & 17.7 & 34.1 \\
\hline $1993 \ldots \ldots \ldots \ldots \ldots \ldots$ & 109,200 & 58.8 & 0 & 17.1 & 24.1 \\
\hline \multicolumn{6}{|l|}{ U.S. Total } \\
\hline $1988 \ldots \ldots \ldots \ldots \ldots \ldots$ & 853,930 & 57.5 & 13.5 & 12.3 & 16.1 \\
\hline $1993 \ldots \ldots \ldots \ldots \ldots \ldots \ldots$ & 883,934 & 59.8 & 13.9 & 13.1 & 13.2 \\
\hline
\end{tabular}

Includes shipments involving barge transportation and any other transportation mode.

IIncludes Great Lakes, tidewater, conveyor, tramway, and slurry pipeline shipments.

Note: U.S. Total includes the New England and Pacific Census Divisions, and coal for which the destination or the transportation mode is unknown.

Sources: 1988: Energy Information Administration, Coal Distribution January-December 1988, DOE/EIA-0125 (88/4Q) (Washington, DC, March 1989), p. 26.1993 : Energy Information Administration, Coal Industry Annual 1993, DOE/EIA-0584(93) (Washington, DC, December 1994), pp. 111-120.

Truck transportation exceeded 20 percent of the total in the Middle Atlantic and East South Central regions, while other transportation modes combined accounted for more than 20 percent of shipments in the West North Central Region (because of the use of conveyors at minemouth power plants in North Dakota) and in the Mountain Region, where conveyor and coal slurry pipeline transportation are important.

\section{Coal Supply Regions}

In 1993, 11 coal supply regions accounted for virtually all of the coal distributed in the United States (Figure
2 and Table 3). Together, two of these regions supplied more than half of the coal shipped to domestic destinations. The Powder River Basin accounted for 28 percent of the total, and Central Appalachia accounted for 24 percent. The Powder River Basin of Wyoming is the major source of low-sulfur, low Btu subbituminous coal, while Central Appalachia is the primary source of low-sulfur, high-Btu bituminous coal. The minemouth price of Powder River Basin coal is substantially lower than that of other coals, reflecting both its low heat content and its low cost of production.

Northern Appalachia and the Illinois Basin produce coals with a relatively high sulfur content. In 1993, they 
Figure 2. Coal Supply Regions

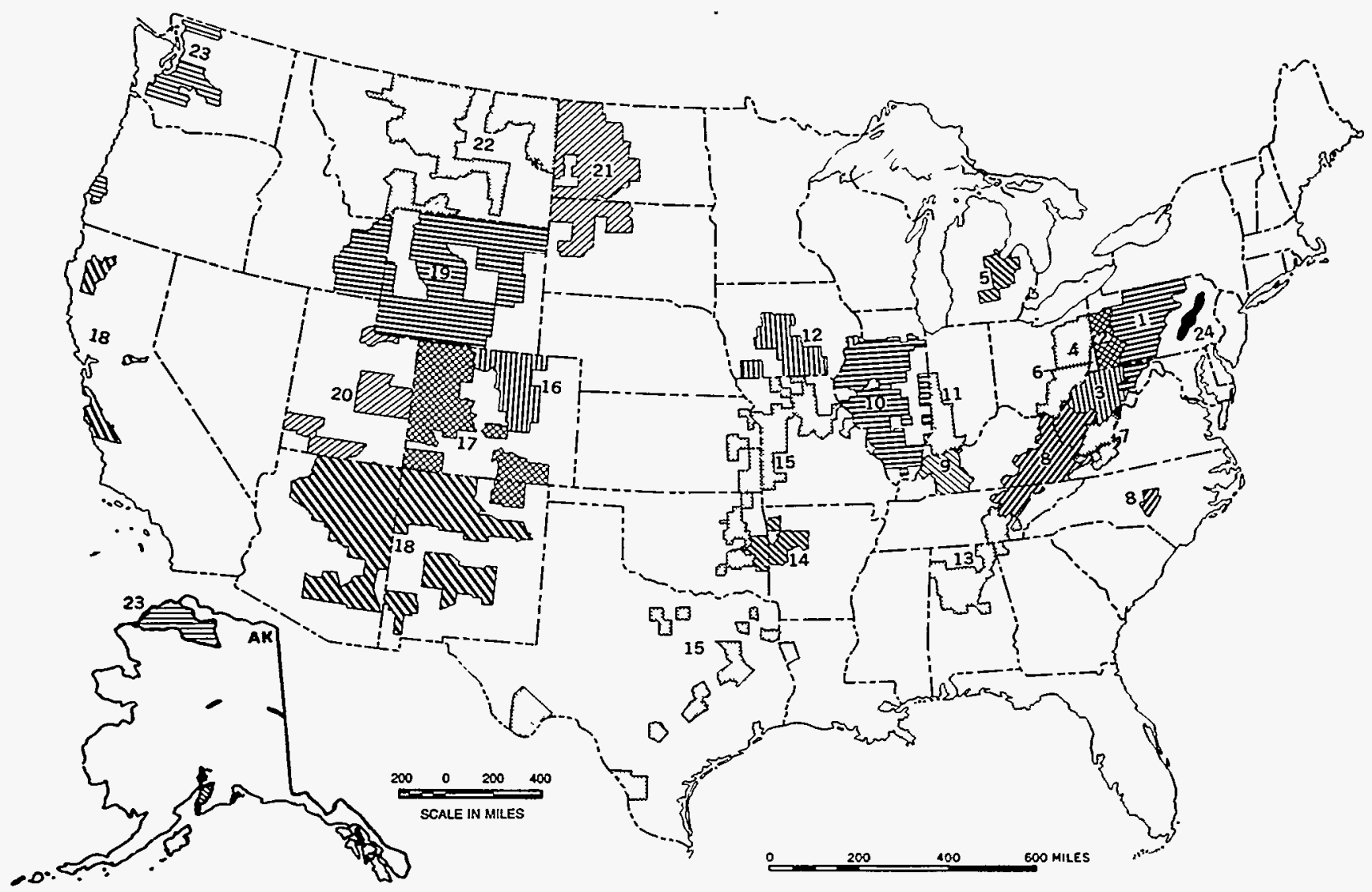

Bituminous Coal Producing Districts as Defined in the Bituminous Coal Act of 1937 and Amendments

The districts were originally established to aid in formulating minimum prices of bituminous coal. and lignite. Because much statistical information was compiled in terms of these districts, their use for statistical purposes has continued since the abandonment of that legislation in 1943. District 24 is the anthracite producing district in Pennsylvania.

\section{Region}

Northern Appalachia

Central Appalachia

Southern Appalachia

Illinois Basin

Texas \& Louisiana Lignite

Other Western Interior

Powder River Basin

North Dakota Lignite

Southwest

Rockies

Northwest

\section{States}

MD, OH, PA, Northern WV

Eastern KY, VA, Southern WV

AL, TN

Western KY, IL, IN

TX, LA

AR, IA, KS, MO, OK

WY, MT

ND

$A Z, N M$

CO, UT

AK, WA

\section{Bureau of Mines Districts}

$$
\begin{aligned}
& 1,2,3,4,6,24 \\
& 7,8
\end{aligned}
$$

13

$9,10,11$

15 (minus KS, MO, OK)

12, 14, 15 (minus TX, LA)

19,22

21

18 (plus Colfax Co. NM)

16, 17 (minus Colfax Co.), 20

23

Source: U.S. Geological Survey, U.S. Department of the Interior. 
Table 3. Coal Supply Regions and Their Domestic Coal Distribution Shares, 1993

\begin{tabular}{|c|c|c|}
\hline Region & $\begin{array}{c}\text { Coal } \\
\text { Distribution } \\
\text { (thousand } \\
\text { short tons) }\end{array}$ & $\begin{array}{c}\text { Percent } \\
\text { of U.S. } \\
\text { Total }\end{array}$ \\
\hline Northern Appalachia . . . . . & 119,648 & 13.5 \\
\hline Central Appalachia ...... & 211,197 & 23.9 \\
\hline Southern Appalachia . . . . . & 22,245 & 2.5 \\
\hline Illinois Basin . . . . . . . . . & 105,956 & 12.0 \\
\hline Texas \& Louisiana Lignite . . & 57,327 & 6.5 \\
\hline Other Western Interior . . . . . & 3,480 & 0.4 \\
\hline Powder River Basin $\ldots \ldots$ & 246,534 & 27.9 \\
\hline North Dakota Lignite . . . . . . & 32,372 & 3.7 \\
\hline Southwest $\ldots \ldots \ldots$ & 40,080 & 4.5 \\
\hline Rockies $\ldots . \ldots \ldots \ldots$. & 39,621 & 4.5 \\
\hline Northwest ........... & 5,476 & 0.6 \\
\hline U.S. Total $\ldots \ldots \ldots \ldots$ & 883,934 & 100.0 \\
\hline
\end{tabular}

Note: Totals may not equal sum of components because of independent rounding.

Source: Energy Information Administration, Coal Industry Annual 1993, DOE/EIA-0584(93) (Washington, DC, December 1994), pp. 90-102.

were the sources for 14 percent and 12 percent, respectively, of total domestic coal distribution. The Rockies accounted for only about 5 percent of the coal distributed domestically in 1993. This region is included in the following analysis because it is the primary Western source of bituminous coal used by electric utilities in the Midwest.

The five coal supply regions examined in this analysis accounted for about four-fifths of total domestic coal distribution in 1993. The other regions were excluded from the regional analysis because they account for a small proportion of total coal distribution, and their coal is used locally, is largely committed to a single utility under a long-term contract, and/or is not shipped by rail. Southern Appalachian (essentially Alabama) coal is mostly used by Alabama Power Co., exported, or used by Alabama steel mills. Texas and Louisiana lignite is consumed at nearby power plants because of its low heat content and high moisture content (making it uneconomical and hazardous for long-distance shipment). North Dakota lignite is used primarily at minemouth power plants and the Great Plains coal gasification facility. Most of the coal from the Southwest Region (Arizona and New Mexico) is used within the State or is shipped by coal slurry pipeline and private railroad.

Between 1988 and 1993, high-sulfur coal production regions lost domestic market share to low-sulfur coal supply regions. Most of this change took place in 1993. The most significant change was the increase in the Powder River Basin's share of coal shipments, from 24 percent in 1988 to 28 percent in 1993 (Table 4). Central Appalachia's share rose less, from 23 percent to 24 percent. Over the same period, Northern Appalachia's share fell from 17 percent to 14 percent, and the Illinois Basin's share fell from 15 percent to 12 percent. Changes were even greater for rail-shipped coal. The Powder River Basin was the source of 40 percent of rail-shipped coal in 1993, up from 33 percent in 1988. Over the same period, the Illinois Basin's rail-shipped share fell from 13 percent to 8 percent.

Railroads are the predominant transporters of coal from most of the coal supply regions, particularly those in the West. In 1993, railroads accounted for 85 percent of the coal distributed domestically from the Powder River Basin and 66 percent of the coal from the Rockies, as well as 69 percent of Central Appalachian coal (Table 5). Between 1988 and 1993, rail gained market share from other transportation modes in the West (up by 8 percent in the Powder River Basin and by 7 percent in the Rockies) and lost market share in the East (down by 16 percent in the Illinois basin, 7 percent in Central Appalachia, and 4 percent in Northern Appalachia). ${ }^{3}$

\section{Distribution Between Supply and Demand Regions}

In 1993, by far the greatest volume of domestic coal shipments occurred between the Central Appalachia supply region and the South Atlantic demand region (Table 6). Coal traffic between these regions exceeded 100 million tons, reflecting the high demand of electric utilities in the South Atlantic Region for low-sulfur, high-Btu coal and the proximity of the Central Appalachian coalfields.

Two other demand regions received more than 70 million tons of coal from a single supply region. Excluding its indigenous supplies of lignite, the West South Central Region (primarily Texas) received virtually all of its coal (77 million tons) from Wyoming's Powder River Basin. The West North Central Region also

\footnotetext{
${ }^{3}$ Energy Information Administration, Coal Industry Annual 1993, DOE/EIA-0584(93) (Washington, DC, December 1994), pp. 111-120, and Coal Distribution January-December 1988, DOE/EIA-0125(88/4Q) (Washington, DC, March 1989), p. 17.
} 
Table 4. Supply Region Shares of Domestic Coal Distribution, 1988-1993

\begin{tabular}{|c|c|c|c|c|c|c|}
\hline \multirow{3}{*}{ Supply Region } & \multicolumn{6}{|c|}{ All Coal } \\
\hline & \multicolumn{6}{|c|}{ Share of Total Tonnage (percent) } \\
\hline & 1988 & 1989 & 1990 & 1991 & 1992 & 1993 \\
\hline Northern Appalachia $\ldots \ldots \ldots \ldots$ & 16.5 & 16.6 & 16.3 & 15.5 & 15.4 & 13.5 \\
\hline Central Appalachia $\ldots \ldots \ldots \ldots$ & 22.8 & 20.4 & 22.8 & 21.9 & 22.7 & 23.9 \\
\hline Illinois Basin $\ldots \ldots \ldots \ldots \ldots$ & 15.2 & 15.2 & 15.3 & 14.5 & 14.5 & 12.0 \\
\hline Powder River Basin & 23.7 & 23.6 & 24.0 & 26.1 & 25.4 & 27.9 \\
\hline Rockies $\ldots \ldots \ldots \ldots \ldots \ldots$ & 3.7 & 4.0 & 4.1 & 4.1 & 4.1 & 4.5 \\
\hline Other $\ldots \ldots \ldots \ldots \ldots \ldots \ldots$ & 18.2 & 18.2 & 17.5 & 17.8 & 17.9 & 18.2 \\
\hline \multirow[t]{2}{*}{ U.S. Total $\ldots \ldots \ldots \ldots \ldots$} & 100.0 & 100.0 & 100.0 & 100.0 & 100.0 & 100.0 \\
\hline & \multicolumn{6}{|c|}{ Rail-Shipped Coal } \\
\hline Northern Appalachia . ........ & 10.5 & 10.3 & 9.9 & 9.4 & 9.3 & 7.9 \\
\hline Central Appalachia...$\ldots \ldots \ldots$ & 29.2 & 28.8 & 28.5 & 27.1 & 27.8 & 27.4 \\
\hline Illinois Basin . . . . . . . . . . & 12.9 & 12.7 & 12.2 & 11.1 & 11.4 & 8.3 \\
\hline Powder River Basin $\ldots \ldots \ldots \ldots$ & 33.2 & 33.3 & 33.8 & 36.8 & 36.1 & 39.5 \\
\hline Rockies $\ldots \ldots \ldots \ldots \ldots \ldots$ & 4.0 & 4.4 & 4.5 & 4.5 & 4.6 & 4.9 \\
\hline Other.$\ldots \ldots \ldots \ldots \ldots \ldots$ & 10.3 & 10.4 & 11.1 & 11.1 & 10.8 & 12.0 \\
\hline U.S. Total $\ldots \ldots \ldots \ldots \ldots \ldots$ & 100.0 & 100.0 & 100.0 & 100.0 & 100.0 & 100.0 \\
\hline
\end{tabular}

Notes: U.S. total for 1989 includes tonnage for which the origin (supply region) is unknown. Totals may not equal sum of components due to independent rounding.

Sources: Energy Information Administration, Coal Industry Annual 1993, DOE/EIA-0584(93) (Washington, DC, December 1994), pp. 90-102 and 111-120; Quarterly Coal Report October-December 1992, DOE/EIA-0121(92/4Q) (Washington, DC, May 1993) pp. 29-33; Coal Distribution January-December 1990, DOE/EIA-0125(90/4Q) (Washington, DC, April 1991), p. 25; Coal Distribution January-December 1988, DOElElA-0125(88/4Q) (Washington, DC, March 1989), pp. 28-30.

Table 5. Domestic Coal Distribution by Supply Region and Transportation Mode, 1993

\begin{tabular}{|c|c|c|c|c|c|}
\hline \multirow[b]{2}{*}{ Supply Region } & \multirow{2}{*}{$\begin{array}{l}\text { Total Tonnage } \\
\text { (thousand } \\
\text { short tons) }\end{array}$} & \multicolumn{4}{|c|}{ Percent of Total } \\
\hline & & Rail & Barge $^{a}$ & Truck & Other \\
\hline Northern Appalachia . & 119,648 & 34.8 & 24.0 & 27.1 & 14.1 \\
\hline Central Appalachia .. & 211,197 & 68.7 & 20.5 & 5.4 & 5.4 \\
\hline Illinois Basin $\ldots \ldots \ldots \ldots \ldots \ldots \ldots$ & 105,956 & 41.3 & 36.2 & 19.2 & 3.3 \\
\hline Powder River Basin & 246,534 & 84.6 & 3.3 & 1.5 & 10.6 \\
\hline Rockies $\ldots \ldots \ldots \ldots \ldots \ldots \ldots \ldots$ & 39,621 & 65.5 & 2.0 & 25.4 & 7.1 \\
\hline Other $\ldots \ldots \ldots \ldots \ldots \ldots \ldots \ldots \ldots$ & 160,980 & 39.6 & 2.0 & 23.4 & 35.0 \\
\hline U.S. Total $\ldots \ldots \ldots \ldots \ldots \ldots \ldots$ & 883,934 & 59.8 & 13.9 & 13.1 & 13.2 \\
\hline
\end{tabular}

ancludes shipments involving barge and any other transportation mode.

bIncludes Great Lakes, tidewater, conveyor, tramway, and slurry pipeline shipments.

Note: Totals may not equal sum of components because of independent rounding.

Source: Energy Information Administration, Coal Industry Annual 1993, DOE/EIA-0584(93) (Washington, DC, December 1994), pp.111-120. 
Table 6. Domestic Coal Distribution Between Selected Demand and Supply Regions, 1993 (Thousand Short Tons)

\begin{tabular}{|c|c|c|c|c|c|c|c|}
\hline \multirow[b]{2}{*}{ Demand Region } & \multicolumn{7}{|c|}{ Supply Region } \\
\hline & $\begin{array}{l}\text { Northern } \\
\text { Appalachia }\end{array}$ & $\begin{array}{c}\text { Central } \\
\text { Appalachia }\end{array}$ & $\begin{array}{l}\text { Illinois } \\
\text { Basin }\end{array}$ & $\begin{array}{l}\text { Powder } \\
\text { River } \\
\text { Basin }\end{array}$ & Rockies & Other ${ }^{\mathrm{a}}$ & $\begin{array}{c}\text { All } \\
\text { Regions }\end{array}$ \\
\hline Middle Atlantic . ...... & 51,211 & 12,717 & 0 & 0 & 0 & 493 & 64,421 \\
\hline East North Central .... & 35,880 & 51,690 & 50,999 & 53,489 & 2,892 & 1,393 & 196,343 \\
\hline West North Central ..... & 376 & 705 & 9,384 & 71,052 & 1,253 & 33,567 & 116,337 \\
\hline South Atlantic ........ & 26,062 & 102,544 & 11,441 & 938 & 203 & 513 & 141,701 \\
\hline East South Central ..... & 1,816 & 39,129 & 33,841 & 495 & 711 & 21,065 & 97,057 \\
\hline West South Central ..... & 165 & 155 & 71 & 76,692 & 2,628 & 59,953 & 139,664 \\
\hline Mountain $\ldots \ldots \ldots$ & 243 & 238 & 0 & 41,428 & 28,953 & 38,338 & 109,200 \\
\hline U.S. Total $\ldots \ldots \ldots$. & 119,648 & 211,197 & 105,956 & 246,534 & 39,621 & 160,980 & 883,934 \\
\hline $\begin{array}{l}\text { aThe principal other coal } \\
\text { South Central Region; Texe } \\
\text { Notes: U.S. total include } \\
\text { Totals may not equal sum } \\
\text { Source: Energy Informa } \\
\text { 1994), pp. 90-102. }\end{array}$ & $\begin{array}{l}\text { ly source } \\
\text { the Wes } \\
\text { New Ens } \\
\text { nponents }\end{array}$ & $\begin{array}{l}\text { North } \mathrm{Da} \\
\text { th Central R } \\
\text { and Pacific } \\
\text { use of indep }\end{array}$ & $\begin{array}{l}\text { ta, for } \\
\text { ion; an } \\
\text { ensus D } \\
\text { dent ro }\end{array}$ & $\begin{array}{l}\text { st Nort } \\
\text { na and } \\
s \text { and } c\end{array}$ & $\begin{array}{l}\text { ral Res } \\
\text { lexico, } \\
\text { which }\end{array}$ & $\begin{array}{l}\text { Alabam } \\
\text { le Moun } \\
\text { destinati }\end{array}$ & $\begin{array}{l}\text { the East } \\
\text { legion. } \\
\text { unknown. }\end{array}$ \\
\hline
\end{tabular}

received most of its coal (71 million tons) from the Powder River Basin, reflecting its proximity to that area.

Although the East North Central Region received more coal than any other demand region in 1993 (196 million tons), it drew coal fairly equally from four of the major supply regions. Because of their central Midwest location, electric utilities in the East North Central Region can look to several coal mining regions for coal supplies, balancing advantages and disadvantages regarding heat content, sulfur content, minemouth price, and transportation cost.

The distribution of coal among supply and demand regions in 1993 is significantly different from the 1988 distribution, due to shifts from high-sulfur to lowsulfur coal supplies. Consumers in the Middle Atlantic Region shifted from Northern Appalachian to Central Appalachian coals. In 1993, 20 percent of the coal shipped to Mid-Atlantic consumers came from Central Appalachia, compared with only 12 percent in 1988 (Table 7). Thus, Central Appalachia's share of the Middle Atlantic market rose by 60 percent. Central Appalachia also gained market share in the South Atlantic and East South Central regions, primarily at the expense of Illinois Basin producers.
Electric utilities also substituted Powder River Basin coal for Illinois Basin coal. Between 1988 and 1993, the Powder River Basin's share of coal distributed to consumers in the West North Central Region rose from 50 percent to 61 percent, while the Illinois Basin's share fell from 17 percent to 8 percent. In the East North Central Region, the Powder River Basin's share rose from 19 percent to 27 percent, while the Illinois Basin's share fell from 32 percent to 26 percent.

\section{Sulfur Content of Coal Received by Electric Utilities}

Nationwide, the sulfur content of the coal received by electric utilities declined by 13 percent between 1988 and 1993, in terms of average sulfur content per million Btu (Table 8). The decline was greatest in the West North Central Region, where the average sulfur content fell by 36 percent. This decrease was due to a substantial decline in the use of high-sulfur Illinois coal by utilities in Kansas, Iowa, and Minnesota, along with the increased use of low-sulfur coal from Wyoming.

The average sulfur content of electric utility coal receipts also fell substantially (17 percent) in the East North Central Region. This change also resulted from 


\begin{tabular}{|c|c|c|c|c|c|c|}
\hline \multirow[b]{2}{*}{ Demand Region } & \multicolumn{6}{|c|}{ Supply Region } \\
\hline & $\begin{array}{l}\text { Northern } \\
\text { Appalachia }\end{array}$ & $\begin{array}{c}\text { Central } \\
\text { Appalachia }\end{array}$ & $\begin{array}{l}\text { Illinois } \\
\text { Basin }\end{array}$ & $\begin{array}{c}\text { Powder River } \\
\text { Basin }\end{array}$ & Rockies & Other ${ }^{a}$ \\
\hline \multicolumn{7}{|l|}{ Middle Atlantic } \\
\hline $1988 \ldots \ldots$ & 87.7 & 12.3 & 0 & 0 & 0 & 0 \\
\hline $1993 \ldots \ldots \ldots \ldots$ & 79.5 & 19.7 & 0 & 0 & 0 & 0.8 \\
\hline \multicolumn{7}{|l|}{ East North Central } \\
\hline $1988 \ldots \ldots \ldots \ldots$ & 20.4 & 28.9 & 31.9 & 18.7 & 0.1 & 0 \\
\hline $1993 \ldots \ldots \ldots \ldots$ & 18.3 & 26.3 & 26.0 & 27.2 & 1.5 & 0.7 \\
\hline \multicolumn{7}{|l|}{ West North Central } \\
\hline $1988 \ldots \ldots \ldots \ldots$ & 0.1 & 1.2 & 16.9 & 50.0 & 0.2 & 31.6 \\
\hline $1993 \ldots \ldots \ldots \ldots$ & 0.3 & 0.6 & 8.1 & 61.1 & 1.1 & 28.8 \\
\hline \multicolumn{7}{|l|}{ South Atlantic } \\
\hline $1988 \ldots \ldots \ldots \ldots \ldots$ & 22.9 & 65.7 & 11.0 & 0 & 0 & 0.4 \\
\hline $1993 \ldots \ldots \ldots \ldots$ & 18.4 & 72.4 & 8.1 & 0.7 & 0.1 & 0.3 \\
\hline \multicolumn{7}{|l|}{ East South Central } \\
\hline $1988 \ldots \ldots \ldots \ldots \ldots$ & 3.7 & 34.2 & 38.3 & 0 & 0 & 23.8 \\
\hline $1993 \ldots \ldots \ldots \ldots$ & 1.9 & 40.3 & $34.9^{-}$ & 0.5 & 0.7 & 21.7 \\
\hline \multicolumn{7}{|l|}{ West South Central } \\
\hline $1988 \ldots \ldots \ldots$ & 0.1 & 0.2 & 0.1 & 52.3 & 1.8 & 45.5 \\
\hline $1993 \ldots \ldots \ldots \ldots$ & 0.1 & 0.1 & 0.1 & 54.9 & 1.9 & 42.9 \\
\hline \multicolumn{7}{|l|}{ Mountain } \\
\hline $1988 \ldots \ldots$ & 0 & 0.3 & 0 & 41.1 & 26.9 & 31.7 \\
\hline $1993 \ldots \ldots \ldots \ldots$ & 0.2 & 0.2 & 0 & 37.9 & 26.5 & 35.2 \\
\hline \multicolumn{7}{|l|}{ United States } \\
\hline $1988 \ldots \ldots \ldots \ldots \ldots$ & 16.5 & 22.8 & 15.2 & 24.3 & 3.9 & 17.3 \\
\hline $1993 \ldots \ldots \ldots \ldots$ & 13.5 & 23.9 & 12.0 & 27.9 & 4.5 & 18.2 \\
\hline
\end{tabular}

aThe principal other coal supply sources are: North Dakota, for the West North Central Region; Alabama, for the East South Central Region; Texas, for the West South Central Region; and Arizona and New Mexico, for the Mountain Region.

Sources: Energy Information Administration, Coal Industry Annual 1993, DOE/EIA-0584(93) (Washington, DC, December 1994), pp. 90-102; and Coal Distribution January-December 1988, DOE/EIA-0125(88/4Q) (Washington, DC, March 1989), pp. 43-49.

the substitution of low-sulfur Western coals for higher sulfur Eastern coals. The region's receipts of Wyoming coal rose by 80 percent between 1988 and 1993.

Contrasting with the general decline in sulfur content, the average sulfur content for the coal received by utilities in the West South Central Region increased by 22 percent. This change reflected both increased use of Texas lignite by Texas utilities and the increasing average sulfur content of that lignite.
Except for the extraordinary decline in sulfur content of the coal received in the West North Central Region and the increase in the West South Central Region, the change in average sulfur content over the 1988 through 1993 period was correlated with each region's total nameplate generation capacity affected by Phase I of the CAAA90. The greater the affected capacity, the greater was the decline in the average sulfur content of coal receipts (Figure 3 ). 
Table 8. Average Btu and Sulfur Content of Coal Received by Electric Utilities, 1988 and 1993

\begin{tabular}{|c|c|c|c|c|c|}
\hline $\begin{array}{c}\text { Demand Region/ } \\
\text { Year }\end{array}$ & $\begin{array}{l}\text { Receipts } \\
\text { (thousand } \\
\text { short tons) }\end{array}$ & $\begin{array}{c}\text { Average } \\
\text { Btu } \\
\text { Per Pound }\end{array}$ & $\begin{array}{l}\text { Average } \\
\text { Sulfur Content } \\
\text { (pounds per } \\
\text { million Btu) }\end{array}$ & $\begin{array}{c}\text { Percent Change } \\
\text { in Sulfur } \\
\text { Content } \\
1988-1993\end{array}$ & $\begin{array}{l}\text { Nameplate } \\
\text { Capacity } \\
\text { Affected by } \\
\text { Phase } 1^{\mathrm{a}} \\
\text { (gigawatts) }\end{array}$ \\
\hline \multicolumn{6}{|l|}{ Middle Atlantic } \\
\hline $1988 \ldots \ldots \ldots \ldots$ & 51,532 & 12,403 & 1.63 & & \\
\hline $1993 \ldots \ldots \ldots \ldots$ & 46,511 & 12,556 & 1.57 & -3.7 & 10.4 \\
\hline \multicolumn{6}{|l|}{ East North Central } \\
\hline $1988 \ldots \ldots \ldots \ldots$ & 155,300 & 11,127 & 1.72 & & \\
\hline $1993 \ldots \ldots \ldots \ldots$ & 165,695 & 10,885 & 1.42 & -17.4 & 34.9 \\
\hline \multicolumn{6}{|l|}{ West North Central } \\
\hline $1988 \ldots \ldots \ldots \ldots$ & 99,540 & 8,710 & 1.16 & & \\
\hline $1993 \ldots \ldots \ldots \ldots$ & 101,896 & 8,366 & 0.74 & -36.2 & 7.9 \\
\hline \multicolumn{6}{|l|}{ South Atlantic } \\
\hline $1988 \ldots \ldots \ldots \ldots$ & 120,976 & 12,478 & 1.21 & -7.4 & 20.5 \\
\hline $1993 \ldots \ldots \ldots \ldots$ & 121,902 & 12,465 & 1.12 & & \\
\hline \multicolumn{6}{|l|}{ East South Central } \\
\hline $1988 \ldots \ldots \ldots \ldots$ & 73,868 & 11,912 & 1.74 & & \\
\hline $1993 \ldots \ldots \ldots \ldots$ & 86,677 & 11,988 & 1.63 & -6.3 & 15.2 \\
\hline \multicolumn{6}{|l|}{ West South Central } \\
\hline $1988 \ldots \ldots \ldots \ldots$ & 117,144 & 7,717 & 0.78 & & \\
\hline $1993 \ldots \ldots \ldots \ldots$ & 130,971 & 7,646 & 0.95 & 21.8 & 0 \\
\hline \multicolumn{6}{|l|}{ Mountain } \\
\hline $1988 \ldots \ldots \ldots \ldots$ & 97,184 & 9,737 & 0.56 & & \\
\hline $1993 \ldots \ldots \ldots \ldots$ & 103,137 & 9,751 & 0.56 & 0.0 & 0 \\
\hline \multicolumn{6}{|l|}{ U.S. Total } \\
\hline $1988 \ldots \ldots \ldots \ldots$ & 727,776 & 10,451 & 1.27 & & \\
\hline $1993 \ldots \ldots \ldots \ldots$ & 769,152 & 10,315 & 1.11 & -12.6 & 89.0 \\
\hline
\end{tabular}

${ }^{\text {a }}$ Phase I requirements of the Clean Air Act of 1990.

Note: U.S. Total includes the New England, Pacific Contiguous, and Pacific Noncontiguous Census regions.

Sources: Energy Information Administration, Cost and Quality of Fuels for Electric Utility Plants 1993, DOE/EIA-0191(93) (Washington, DC, July 1994), pp. 14, 30, and 44-48; Cost and Quality of Fuels for Electric Utility Plants 1988, DOE/EIA-0191(88) (Washington, DC, August 1989), pp. 71-75; and Acid Rain Compliance Strategies for the Clean Air Act Amendments of 1990, DOE/EIA-0582 (Washington, DC, March 1994), p. 3. 
Figure 3. Relationship Between Nameplate Generating Capacity Affected by Phase I and Percentage Change in Average Sulfur Content for Seven Coal Demand Regions

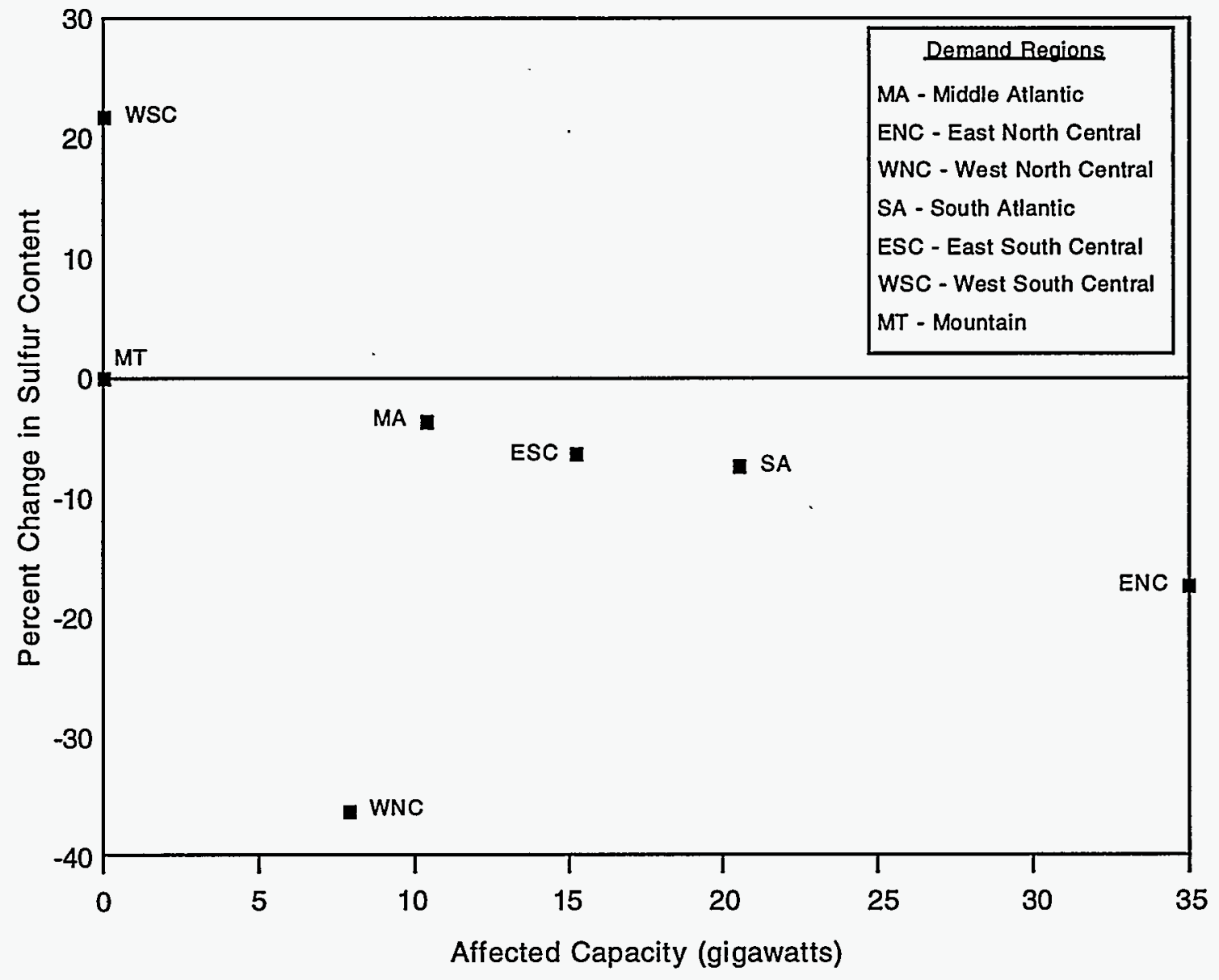

Notes: "Percentage Change in Average Sulfur Content" refers to the change between 1988 and 1993 in the average sulfur content per million Btu for coal received by electric utilities. Nameplate generating capacity is for electric utility plants affected by Phase I of the Clean Air Act Amendments of 1990.

Sources: Energy Information Administration, Cost and Quality of Fuels for Electric Utility Plants 1993, DOE/EIA-0191(93) (Washington, DC, July 1994), pp. 14, 30, and 44-48, and Cost and Quality of Fuels for Electric Utility Plants 1988, DOE-ElA0191 (88) (Washington, DC, August 1989), pp. 71-75. 


\section{Railroad Coal Transportation and Transportation Rates}

Railroad transportation is vital to most major U.S. coal consumers and producers. Nearly 60 percent of the coal shipped to domestic consumers in 1993 was transported by rail, not counting the coal shipped in combined railbarge movements (Table 2, Chapter 1). Railroad transportation is even more important in some of the Nation's coal demand regions, accounting for 71 percent of the coal delivered to consumers in the South Atlantic Region. Since shipping distance is longer for rail hauls than for other transportation modes, railroad transportation is also more important in terms of tonmiles than in terms of tons of coal hauled. Coal transportation is also important to the railroads. In 1993, coal accounted for 38 percent of the freight tonnage hauled by Class I railroads and 21 percent of their freight revenues. ${ }^{4}$

This section presents information on electric utility contract coal shipped by rail from 1988 through 1993, including sulfur content, distance shipped, and transportation rates. First, national trends are discussed. Then, changes in each relevant coal demand and supply region are examined.

\section{National Trends in Sulfur Content and Transportation Rates for Rail-Shipped Coal}

Between 1988 and 1993, the volume of "compliance coal $^{\prime 5}$ shipped by rail under electric utility contracts rose by 27 percent, while the volume of high-sulfur coal fell by 33 percent. As a result, by 1993, compliance coal accounted for 56 percent of the total, up from 46 percent in 1988 (Table 9). Over the same period, the share held by high-sulfur coal fell from 18 percent to 12 percent.

Generally, the lower the sulfur content of the coal, the greater the distance it was shipped. In 1993, compliance coal was shipped an average of 952 miles, while highsulfur coal was shipped an average of only 145 miles (Table 10). In part, this difference occurs because the low minemouth price of Western Region compliance coal offsets the cost of shipping it further distances. Another factor is that the electric utility plants using the high-sulfur coal reserves of the Illinois Basin

Table 9. Rail-Shipped Contract Coal Tonnage by Sulfur Category, 1988-1993

\begin{tabular}{|c|c|c|c|c|c|}
\hline \multirow[t]{2}{*}{ Year } & \multirow{2}{*}{$\begin{array}{l}\text { Tonnage } \\
\text { (million } \\
\text { short tons) }\end{array}$} & \multicolumn{4}{|c|}{ Percentage Distribution } \\
\hline & & Compliance & Low Sulfur & Medium Sulfur & High Sulfur \\
\hline 1988 & 232.7 & 45.9 & 27.4 & 8.5 & 18.2 \\
\hline $1989 \ldots$ & 231.0 & 46.8 & 24.9 & 10.6 & 17.6 \\
\hline $1990 \ldots \ldots \ldots \ldots \ldots \ldots$ & 266.2 & 42.2 & 30.5 & 9.8 & 17.5 \\
\hline $1991 \ldots \ldots \ldots \ldots \ldots \ldots$ & 265.1 & 45.5 & 29.5 & 9.0 & 16.0 \\
\hline $1992 \ldots \ldots \ldots \ldots \ldots \ldots \ldots$ & 244.8 & 48.1 & 24.5 & 10.5 & 16.9 \\
\hline $1993 \ldots \ldots \ldots \ldots \ldots \ldots \ldots$ & 242.5 & 55.8 & 24.0 & 8.5 & 11.7 \\
\hline
\end{tabular}

Notes: Compliance $=$ less than or equal to 0.6 pounds of sulfur per million Btu; Low Sulfur $=0.61$ to 1.25 pounds per million Btu; Medium Sulfur $=1.26$ to 1.67 pounds per million Btu; High Sulfur = greater than 1.67 pounds per million Btu. Percentages may not total 100 because of rounding.

Source: Energy Information Administration, Coal Transportation Rate Data Base.

\footnotetext{
${ }^{4}$ Association of American Railroads, Freight Commodity Statistics. Effective January 1, 1978, Class I railroads were defined as those with annual operating revenues of $\$ 50$ million or more. Subsequently adjusted for inflation, the cut-off currently exceeds $\$ 90$ million.

${ }^{5}$ Defined as coal with a sulfur content of 0.6 pounds of sulfur per million Btu of heat input or less, meeting the Phase II limit of 1.2 pounds of sulfur dioxide per million Btu of heat input.
} 
Table 10. Average Distance of Contract Coal Rail Shipments by Sulfur Category, 1988-1993 (Miles)

\begin{tabular}{cc|c|c|c|c}
\hline \multicolumn{1}{c|}{ Year } & All Coal & Compliance & Low Sulfur & Medium Sulfur & High Sulfur \\
\hline $1988 \ldots \ldots \ldots \ldots \ldots$ & 603.9 & 943.8 & 458.0 & 224.9 & 143.1 \\
$1989 \ldots \ldots \ldots \ldots \ldots$ & 603.7 & 943.5 & 462.7 & 211.6 & 127.0 \\
$1990 \ldots \ldots \ldots \ldots \ldots$ & 572.6 & 917.9 & 450.8 & 226.2 & 152.2 \\
$1991 \ldots \ldots \ldots \ldots$ & 591.7 & 937.1 & 439.6 & 214.8 & 157.2 \\
$1992 \ldots \ldots \ldots \ldots$ & 602.4 & 942.7 & 434.4 & 192.0 & 155.7 \\
$1993 \ldots \ldots \ldots \ldots$ & 671.3 & 952.3 & 459.4 & 191.2 & 145.1 \\
\hline
\end{tabular}

Notes: Compliance $=$ less than or equal to 0.6 pounds of sulfur per million Btu; Low Sulfur $=0.61$ to 1.25 pounds per million Btu; Medium Sulfur = 1.26 to 1.67 pounds per million Btu; High-Sulfur = greater than 1.67 pounds per million Btu.

Source: Energy Information Administration, Coal Transportation Rate Data Base.

generally are located close to the coal mines. Finally, the increased value placed upon compliance coal due to CAAA90 requirements means that it can be sold at a higher delivered price than other coals, enabling relatively high transportation costs to be absorbed.

The average shipping distance for all utility contract coal shipped by rail increased by 11 percent between 1988 and 1993, to 671 miles. The average shipping distance for medium-sulfur coal declined, and it changed little for the other sulfur content categories. The data indicate that the overall upward trend in shipping distance was due to the substitution of compliance coal (which has a high average shipping distance) for high-sulfur coal (with a low average shipping distance).

Coal and railroad industry publications of the past few years are replete with accounts of Powder River Basin coal being shipped great distances. Several electric utilities reported one-way coal hauls of between 1,000 and 1,500 miles. ${ }^{6}$ However, the data used in this report show that the average distance for rail shipments of compliance coal increased by less than 1 percent between 1988 and 1993, to 952 miles. Partly, the increase was slight because almost three-fourths of the new coal shipments from the Powder River Basin went to the contiguous West North Central Demand Region. Perhaps more recent (but as yet unavailable) data will show a greater increase in the average distance for compliance coal shipments. It is also possible that some of the reported long hauls are for spot purchases, rather than for contract coal shipments, or are multimodal, rather than all-rail, shipments.

\section{Rate per Ton}

Shipping distance has a significant impact on the cost of moving coal by rail. If all other factors remain constant, greater distance generally results in a higher transportation rate per ton of coal shipped. Because average shipping distance varies inversely with average sulfur content, the average transportation rate is substantially higher for compliance coal than for highsulfur coal. In 1993, the average transportation cost was $\$ 10.73$ per ton for compliance coal, compared with $\$ 3.94$ per ton for high-sulfur coal (Table 11). ${ }^{7}$

Railroad coal transportation rates declined substantially between 1988 and 1993. For contract coal shipments to electric utilities, the average rate fell to $\$ 8.93$ per ton, about four-fifths of its 1988 level. The average transportation rate fell fairly evenly across the different sulfur content categories, with the rates for compliance coal and high-sulfur coal falling by nearly the same percentage (about 26 percent). The average rate for all coal combined fell by less than the average for each of the sulfur categories, because compliance coal (with the highest transportation rate per ton) accounted for a greater proportion of the total over time, while the share of high-sulfur coal (with the lowest transportation rate) declined. These data indicate that the railroads generally did not take advantage of the increasing demand for compliance coal that resulted from CAAA90 by raising their rates.

The percentage decline in the average transportation cost per ton was greatest for contract coal shipments from Central Appalachia to utilities in the East South Central Region (Table 12). The decline was also

${ }^{6}$ Progressive Railroading (Chicago: Trade Press Publishing Company, July 1995), p. 47-49.

${ }^{7}$ Throughout this chapter, rates, prices, and costs have been adjusted for inflation by converting them to constant 1987 dollars. 
Table 11. Average Rate per Ton for Contract Coal Rail Shipments by Sulfur Category, 1988-1993 (1987 Dollars per Short Ton)

\begin{tabular}{c|c|c|c|c|c}
\hline Year & All Coal & Compliance & Low Sulfur & Medium Sulfur & High Sulfur \\
\hline $1988 \ldots \ldots \ldots \ldots \ldots$ & 11.08 & 14.39 & 10.75 & 8.26 & 5.36 \\
$1989 \ldots \ldots \ldots \ldots \ldots$ & 10.33 & 13.41 & 10.82 & 6.32 & 4.68 \\
$1990 \ldots \ldots \ldots \ldots \ldots$ & 9.83 & 13.37 & 9.14 & 7.29 & 4.39 \\
$1991 \ldots \ldots \ldots \ldots \ldots$ & 9.41 & 12.20 & 8.89 & 7.04 & 4.37 \\
$1992 \ldots \ldots \ldots \ldots \ldots$ & 8.89 & 11.66 & 8.48 & 5.88 & 4.06 \\
$1993 \ldots \ldots \ldots \ldots$ & 8.93 & 10.73 & 8.39 & 5.99 & 3.94 \\
\hline
\end{tabular}

Notes: Compliance $=$ less than or equal to 0.6 pounds of sulfur per million Btu; Low Sulfur $=0.61$ to 1.25 pounds per million Btu; Medium Sulfur = 1.26 to 1.67 pounds per million Btu; High-Sulfur = greater than 1.67 pounds per million Btu.

Source: Energy Information Administration, Coal Transportation Rate Data Base.

Table 12. Average Rate per Ton for Contract Coal Rail Shipments Between Selected Supply and Demand Regions, 1988 and 1993

(1987 Dollars per Ton)

\begin{tabular}{|c|c|c|c|c|c|}
\hline \multirow[b]{2}{*}{ Demand Region } & \multicolumn{5}{|c|}{ Supply Region } \\
\hline & $\begin{array}{c}\text { Northern } \\
\text { Appalachia }\end{array}$ & $\begin{array}{c}\text { Central } \\
\text { Appalachia }\end{array}$ & $\begin{array}{l}\text { Illinois } \\
\text { Basin }\end{array}$ & $\begin{array}{c}\text { Powder } \\
\text { River Basin }\end{array}$ & Rockies \\
\hline \multicolumn{6}{|l|}{ Middle Atlantic } \\
\hline $1988 \ldots \ldots \ldots \ldots \ldots \ldots \ldots \ldots$ & 11.99 & 19.58 & -- & -- & -- \\
\hline $1993 \ldots \ldots \ldots \ldots \ldots \ldots \ldots$ & 7.43 & 16.66 & -- & -- & -- \\
\hline Percent Change $\ldots \ldots \ldots \ldots$ & -38.0 & -14.9 & - & -- & -- \\
\hline \multicolumn{6}{|l|}{ East North Central } \\
\hline $1988 \ldots \ldots \ldots \ldots \ldots \ldots \ldots$ & 7.01 & 12.73 & 3.67 & 18.16 & $w$ \\
\hline $1993 \ldots \ldots \ldots \ldots \ldots \ldots \ldots$ & 5.47 & 10.31 & 2.49 & 11.73 & $w$ \\
\hline Percent Change $\ldots \ldots \ldots \ldots \ldots$ & -22.0 & -19.0 & -32.2 & -35.4 & -43.7 \\
\hline \multicolumn{6}{|l|}{ West North Central } \\
\hline $1988 \ldots \ldots \ldots \ldots \ldots \ldots \ldots$ & - & -- & 9.39 & 11.39 & -- \\
\hline $1993 \ldots \ldots \ldots \ldots \ldots \ldots \ldots$ & -- & -- & 5.21 & 9.07 & $w$ \\
\hline Percent Change $\ldots \ldots \ldots \ldots \ldots$ & -- & -- & -44.5 & -20.4 & -. \\
\hline \multicolumn{6}{|l|}{ South Atlantic } \\
\hline $1988 \ldots \ldots$ & 8.71 & 10.98 & -- & - & -- \\
\hline $1993 \ldots \ldots \ldots \ldots \ldots \ldots \ldots$ & 8.80 & 9.18 & 16.02 & -- & -- \\
\hline Percent Change $\ldots \ldots \ldots \ldots$ & 1.0 & -16.4 & -- & -. & -- \\
\hline \multicolumn{6}{|l|}{ East South Central } \\
\hline $1988 \ldots \ldots \ldots \ldots \ldots \ldots \ldots$ & -- & 13.71 & 3.55 & -- & -- \\
\hline $1993 \ldots \ldots \ldots \ldots \ldots \ldots \ldots$ & -- & 5.45 & 2.91 & - & w \\
\hline Percent Change $\ldots \ldots \ldots \ldots$. & -- & -60.2 & -18.0 & -- & - \\
\hline \multicolumn{6}{|l|}{ West South Central } \\
\hline $1988 \ldots \ldots \ldots \ldots \ldots \ldots \ldots$ & -- & -- & -- & 18.65 & w \\
\hline $1993 \ldots \ldots \ldots \ldots \ldots \ldots \ldots$ & -- & -- & -- & 13.23 & w \\
\hline Percent Change $\ldots \ldots \ldots \ldots$ & -- & -- & -- & -29.1 & -14.7 \\
\hline \multicolumn{6}{|l|}{ Mountain } \\
\hline $1988 \ldots \ldots \ldots \ldots \ldots \ldots \ldots$ & -- & -- & -- & 8.68 & 10.97 \\
\hline $1993 \ldots \ldots \ldots \ldots \ldots \ldots \ldots$ & -- & -- & -- & 5.23 & 7.91 \\
\hline Percent Change $\ldots \ldots \ldots \ldots$. & -- & -- & -- & -39.7 & -27.9 \\
\hline
\end{tabular}

$W=$ Withheld to avoid disclosure of confidential data.

-- = Not applicable.

Sources: Energy Information Administration, Coal Transportation Rate Data Base. 
relatively great for shipments from the Illinois Basin to the West North Central Region, and for shipments from the Rockies to the East North Central Region.

In contrast, the average transportation cost for shipments from Northern Appalachia to utilities in the South Atlantic Region rose by 1 percent. Also, the fall in transportation cost was relatively small (about 15 percent) for shipments from the Rockies to the West South Central Region, and for shipments from Central Appalachia to Middle Atlantic utilities.

Why did railroad coal transportation rates fall between 1988 and 1993, even though the average distance shipped increased? Basically, the drop resulted from the generally high degree of competition in the railroad and coal industries and the willingness of the two industries to cooperate in ways that benefit the industries themselves and their customers. Competition encourages coal producers to keep their delivered coal prices as low as possible in order to increase their sales volume and revenue. For coal markets to expand, transportation costs must be kept low. Another factor causing rail rates to decline was that utilities secured lower rates by increasing the use of their owned or leased rail cars, rather than railroad-owned cars.

Deregulation of the railroad industry in 1980 allowed railroads greater marketing and pricing flexibility. It also allowed the industry to restructure itself, through mergers and line abandonments. Costs were reduced as well through the downsizing of equipment and work forces. Costs fell even faster than rates, and some railroads actually began to see profits in an industry that had long been unprofitable. Free to negotiate contract transportation rates, railroads found that they could increase their net revenues substantially even when lowering their rates.

\section{Rate per Million Btu}

Coal producers have an interest in minimizing the transportation rate per ton, in order to keep the delivered cost of their coal as low as possible. However, electric utilities are more interested in the transportation rate per million Btu, since they buy coal for its heat content. This objective may lead a utility to purchase coal with a relatively high delivered price per ton if the heat content of the coal is also relatively high, because the delivered price per Btu will be lower.

Between 1988 and 1993, for contract coal shipments by rail, the trend in the average transportation rate per million Btu followed the same downward trend as the trend in the average rate per ton (Table 13). The magnitude of the change was somewhat less for the rate per million Btu (down by 17 percent) than for the rate per ton (down by nearly 20 percent). This difference is primarily due to the rapid growth of shipments from the Powder River Basin, where the average Btu content of the coal is relatively low, and the declining shipments of higher-Btu, high-sulfur coal.

\section{Transportation Cost as a Percentage of Delivered Price}

For rail-shipped contract coal, transportation cost accounted for nearly 50 percent of the delivered price of compliance coal in 1993, compared with about 15 percent of the delivered price of high-sulfur coal (Table 14). This contrast reflects the differences in the average shipping distance for the different coal types. As noted above, shipping distance varies inversely with the sulfur content of the coal. In particular, the average haul is much longer for compliance coal from Wyoming's Powder River Basin than for high-sulfur coal from the Illinois Basin.

Table 13. Average Rate per Million Btu for Contract Coal Rail Shipments by Sulfur Category, 1988-1993 (Cents per Million Btu in 1987 Dollars)

\begin{tabular}{|c|c|c|c|c|c|}
\hline Year & All Coal & Compliance & Low Sulfur & Medium Sulfur & High Sulfur \\
\hline $1988 \ldots \ldots \ldots \ldots$ & 51.6 & 74.5 & 45.8 & 35.8 & 23.6 \\
\hline $1989 \ldots \ldots \ldots \ldots$ & 48.5 & 70.5 & 45.9 & 27.6 & 20.6 \\
\hline $1990 \ldots$ & 46.0 & 71.4 & 39.5 & 31.1 & 19.1 \\
\hline $1991 \ldots$ & 44.1 & 65.1 & 37.9 & 30.0 & 19.0 \\
\hline $1992 \ldots$ & 41.8 & 61.5 & 36.3 & 25.2 & 17.7 \\
\hline $1993 \ldots \ldots \ldots \ldots$ & 43.0 & 57.1 & 36.5 & 25.8 & 17.1 \\
\hline
\end{tabular}

Notes: Compliance $=$ less than or equal to 0.6 pounds of sulfur per million Btu; Low Sulfur $=0.61$ to 1.25 pounds per million Btu; Medium Sulfur = 1.26 to 1.67 pounds per million Btu; High-Sulfur = greater than 1.67 pounds per million Btu.

Source: Energy Information Administration, Coal Transportation Rate Data Base. 
Table 14. Transportation Cost as a Percentage of Delivered Price for Contract Coal Rail Shipments by Sulfur Category, 1988-1993

\begin{tabular}{cc|c|c|c|c|c}
\hline \multicolumn{2}{c|}{ Year } & All Coal & Compliance & Low Sulfur & Medium Sulfur & High Sulfur \\
\hline $1988 \ldots \ldots \ldots \ldots \ldots$ & 32.8 & 47.6 & 28.1 & 22.7 & 15.3 \\
$1989 \ldots \ldots \ldots \ldots \ldots$ & 32.4 & 47.6 & 29.6 & 17.8 & 14.3 \\
$1990 \ldots \ldots \ldots \ldots \ldots$ & 32.0 & 50.2 & 25.9 & 21.0 & 14.6 \\
$1991 \ldots \ldots \ldots \ldots \ldots$ & 32.3 & 49.2 & 25.6 & 20.8 & 15.3 \\
$1992 \ldots \ldots \ldots \ldots$ & 32.6 & 48.4 & 26.3 & 18.8 & 15.2 \\
$1993 \ldots \ldots \ldots \ldots$ & 35.5 & 47.9 & 27.9 & 21.5 & 15.2 \\
\hline
\end{tabular}

Notes: Compliance $=$ less than or equal to 0.6 pounds of sulfur per million Btu; Low Sulfur $=0.61$ to 1.25 pounds per million Btu; Medium Sulfur = 1.26 to 1.67 pounds per million Btu; High-Sulfur = greater than 1.67 pounds per million Btu.

Source: Energy Information Administration, Coal Transportation Rate Data Base.

As Powder River Basin coal was substituted for Illinois Basin coal from 1988 through 1993, rail transportation cost became a larger proportion of average delivered price, overall. By 1993, transportation cost accounted for 36 percent of the average delivered price, compared with 33 percent in 1988. For compliance coal, the ratio of transportation cost to delivered price fell from 50 percent in 1990 to 48 percent in 1993, as transportation rates declined more than coal prices. The ratio remained quite stable for high-sulfur coal, and there was no clear trend for other coals.

\section{Rate per Ton-Mile}

As noted above, coal transportation cost (i.e., the transportation rate per ton of coal shipped) largely depends on how far the coal is shipped. Changes in the rate per ton reflect changes in shipping distance and in the efficiency of shipping logistics, as well as in operating efficiency. To isolate changes in operating efficiency that result from technological, managerial, communications, and other improvements, it is necessary to adjust for changes in the distance shipped. When comparing rates in different regions or across different coal types, one may also wish to adjust for differences in shipping distance. This adjustment can be made by looking at changes in the average transportation rate per ton per mile the coal is shipped, or the average rate per ton-mile.

The average rate per ton-mile is substantially lower for compliance and low-sulfur coals than for other coals (Table 15). In part, this difference is due to the greater distance they are shipped, compared to other coals, because fixed costs that do not vary with distance are spread over a greater number of miles. Also, western compliance and low-sulfur coals generally are hauled over flat terrain, using highly efficient unit train

Table 15. Average Rate per Ton-Mile for Contract Coal Rail Shipments by Sulfur Category, 1988-1993 (Mills per Ton-Mile in 1987 Dollars)

\begin{tabular}{cc|c|c|c|c|c}
\hline \multicolumn{1}{c|}{ Year } & All Coal & Compliance & Low Sulfur & Medium Sulfur & High Sulfur \\
\hline $1988 \ldots \ldots \ldots \ldots \ldots$ & 19.1 & 15.6 & 23.7 & 35.3 & 38.9 \\
$1989 \ldots \ldots \ldots \ldots \ldots$ & 17.7 & 14.5 & 23.2 & 29.6 & 36.5 \\
$1990 \ldots \ldots \ldots \ldots \ldots$ & 17.5 & 14.7 & 21.0 & 27.5 & 30.6 \\
$1991 \ldots \ldots \ldots \ldots \ldots$ & 16.7 & 13.8 & 20.4 & 27.4 & 30.0 \\
$1992 \ldots \ldots \ldots \ldots$ & 15.1 & 12.4 & 20.4 & 29.4 & 26.6 \\
$1993 \ldots \ldots \ldots \ldots$ & 13.6 & 11.3 & 19.2 & 30.7 & 27.0 \\
\hline
\end{tabular}

Notes: Compliance $=$ less than or equal to 0.6 pounds of sulfur per million Btu; Low Sulfur $=0.61$ to 1.25 pounds per million Btu; Medium Sulfur = 1.26 to 1.67 pounds per million Btu; High-Sulfur = greater than 1.67 pounds per million Btu. One mill equals 0.1 cent.

Source: Energy Information Administration, Coal Transportation Rate Data Base. 
systems. ${ }^{8}$ The relatively large capacity and long distance of unit train shipments from western mines tend to reduce the cost per ton-mile. Costs are also comparatively low for western railroads because they serve relatively few, large coal mines, whereas eastern railroads serve hundreds of small mines.

Between 1988 and 1993, the average rate per ton-mile for rail-shipped contract coal fell by 29 percent, from about 19 mills (or 1.9 cents) to 14 mills (1.4 cents). This drop compares with a 20-percent decline in the average rate per ton, as average shipping distance increased over the period. The fall in the rate per ton-mile reflects the increasing efficiency of rail transportation resulting from technological improvements in equipment (such as more powerful locomotives and lighter rail cars with greater capacity), personnel downsizing (e.g., switching to smaller crews), and improved communications. It is also partly due to a decline in short-distance, high-cost (per ton-mile) movements from Northern Appalachia and the Illinois Basin, combined with an increase in long-distance, low-cost movements from the Powder River Basin.

For compliance coal, the average rate per ton-mile fell by 28 percent between 1988 and 1993. This decrease reflects the intense competition between the Burlington Northern and Chicago and Northwestern railroads for shipments from the Powder River Basin, where coal production has grown rapidly in recent years. For highsulfur coal, the average rate per ton-mile fell by 31 percent. This decrease results from the substantial decline in the amount of high-sulfur coal shipped from mines in Northern Appalachia, much of which had been transported at very high rates per ton-mile. The fall in the average rate per ton-mile was substantially less for the other sulfur content categories.

For the contract coal shipments included in the CTRDB, the percentage decline in the average rate per ton-mile between 1988 and 1993 was greatest for shipments from the Powder River Basin and the Rockies to utilities in the East North Central Region (Table 16). Apparently, the efficiency of these long haul rail movements rose substantially over the period. The decline in the average rate per ton-mile was much less for the short distance rail movements from Northern Appalachia to the Middle Atlantic Region, from Northern Appalachia and the Illinois Basin to the East North Central Region, and from the Powder River Basin to relatively nearby utilities in the Mountain Region.

\section{Demand Region Comparisons for Rail Transportation}

Several important changes in railroad coal transportation at the national level were the result of shifts from the use of high-sulfur coal to the use of compliance coal. Basically, this situation occurred because the different types of coal come from different mining regions and go to electric utilities that are affected by or respond to clean air legislation in different ways. This section examines changes in rail shipments and transportation rates for electric utilities in each of the major coal demand regions (Figure 1, Chapter 1).

\section{Middle Atlantic Region}

When compared to the other coal demand regions, Middle Atlantic Region electric utility coal consumption and transportation are unusual. Nuclear generation is relatively high in the region, so that only 42 percent of total net generation in 1993 was coal-fired, compared with a national average of 57 percent. ${ }^{9}$ Similarly, only 43 percent of the region's coal receipts were hauled by rail, compared with a national average of 60 percent. Truck transportation is more important here than in the other regions, and barge transportation is also significant.

Practically all of the coal burned by the region's electric utility plants comes from Northern Appalachia, and most of it is medium- to high-sulfur coal. Many of the region's coal-fired plants affected by Phase I of CAAA90 have flue gas scrubbers or plan to install them. Therefore, their demand for low sulfur coal has fallen rather than risen.

Rail shipments of contract coal to utilities in the region amounted to 13 million tons in 1993, about the same level as in 1988 (Table 17). Shipments of high-sulfur coal increased by 55 percent between 1988 and 1993, while low-sulfur shipments fell by 93 percent. These developments may have been due to the growing price differential between the two coal types, as well as the increased use of scrubbers. Medium-sulfur coal shipments increased by 16 percent, to 55 percent of the total.

\footnotetext{
${ }^{8} \mathrm{~A}$ unit train operation is an uninterrupted movement of a single commodity from a single source to a single destination. Typically, coal unit trains are sets of at least 100 rail cars, hauled by three to six locomotives, moving coal over a distance of between 250 miles (for eastern origins) and 1,500 miles (for western origins).

${ }^{9}$ Energy Information Administration, Electric Power Annual 1993, DOE/ELA-0348(93) (Washington, DC, December 1994 ), pp. $33-35$.
} 
Table 16. Average Rate per Ton-Mile for Contract Coal Rail Shipments Between Selected Supply and Demand Regions, 1988 and 1993

(Mills per Ton-Mile in 1987 Dollars)

\begin{tabular}{|c|c|c|c|c|c|}
\hline \multirow[b]{2}{*}{ Demand Region } & \multicolumn{5}{|c|}{ Supply Region } \\
\hline & $\begin{array}{c}\text { Northem } \\
\text { Appalachia }\end{array}$ & $\begin{array}{c}\text { Central } \\
\text { Appalachia }\end{array}$ & $\begin{array}{l}\text { Illinois } \\
\text { Basin }\end{array}$ & $\begin{array}{l}\text { Powder } \\
\text { River Basin }\end{array}$ & Rockies \\
\hline \multicolumn{6}{|l|}{ Middle Atlantic } \\
\hline $1988 \ldots \ldots \ldots \ldots \ldots \ldots \ldots$ & 3.2 & 2.7 & - & -- & -- \\
\hline $1993 \ldots \ldots \ldots \ldots \ldots \ldots$ & 3.1 & 2.3 & -- & -- & - \\
\hline Percent Change $\ldots \ldots \ldots \ldots \ldots$ & -3.1 & -14.8 & -- & -- & -- \\
\hline \multicolumn{6}{|l|}{ East North Central } \\
\hline $1988 \ldots \ldots \ldots \ldots \ldots \ldots \ldots$ & 2.5 & 3.1 & 3.5 & 1.5 & $w$ \\
\hline $1993 \ldots \ldots \ldots \ldots \ldots \ldots$ & 2.3 & 2.2 & 3.2 & 0.9 & $w$ \\
\hline Percent Change $\ldots \ldots \ldots \ldots \ldots$ & -8.0 & -29.0 & -8.6 & -40.0 & -42.1 \\
\hline \multicolumn{6}{|l|}{ West North Central } \\
\hline $1988 \ldots \ldots \ldots \ldots \ldots \ldots \ldots$ & -- & -- & 2.8 & 1.4 & -- \\
\hline $1993 \ldots \ldots \ldots \ldots \ldots \ldots \ldots$ & -- & -- & 3.3 & 1.0 & w \\
\hline Percent Change ............ & -- & -- & 17.9 & -28.6 & -- \\
\hline \multicolumn{6}{|l|}{ South Atlantic } \\
\hline $1988 \ldots \ldots \ldots \ldots \ldots \ldots \ldots$ & 5.3 & 2.6 & -- & - & -- \\
\hline $1993 \ldots \ldots \ldots \ldots \ldots \ldots \ldots$ & 3.3 & 2.1 & -- & -- & -- \\
\hline Percent Change...$\ldots \ldots \ldots$ & -37.7 & -19.2 & -- & -- & -- \\
\hline \multicolumn{6}{|l|}{ East South Central } \\
\hline $1988 \ldots \ldots \ldots \ldots \ldots \ldots \ldots$ & -- & 1.5 & 2.5 & -- & -- \\
\hline $1993 \ldots \ldots \ldots \ldots \ldots \ldots \ldots$ & -- & 1.1 & 2.1 & -- & - \\
\hline Percent Change ........... & -- & -26.7 & -16.0 & -- & -- \\
\hline \multicolumn{6}{|l|}{ West South Central } \\
\hline $1988 \ldots \ldots \ldots \ldots \ldots \ldots \ldots$ & -- & -- & -- & 1.4 & $w$ \\
\hline $1993 \ldots \ldots \ldots \ldots \ldots \ldots$ & -- & -- & -- & 1.1 & w \\
\hline Percent Change $\ldots \ldots \ldots \ldots$ & -- & - & -- & -21.4 & -14.3 \\
\hline \multicolumn{6}{|l|}{ Mountain } \\
\hline $1988 \ldots \ldots \ldots \ldots \ldots \ldots \ldots$ & -. & -- & -- & 1.9 & 2.9 \\
\hline $1993 \ldots \ldots \ldots \ldots \ldots \ldots$ & $\cdots$ & -- & -- & 1.8 & 2.2 \\
\hline Percent Change ........... & $\ldots$ & -- & -- & -5.3 & -24.1 \\
\hline
\end{tabular}

$W=$ Withheld to avoid disclosure of confidential data.

$--=$ Not applicable.

Note: One mill equals 0.1 cent.

Sources: Energy Information Administration, Coal Transportation Rate Data Base.

The average distance for contract coal rail movements to utilities in the region was relatively low (258 miles in 1993). The average distance fell by 16 percent from 1988 to 1993, as shipments of compliance coal from Central Appalachia declined. Partly due to this decrease in the average length of haul, the average rail transportation rate per million Btu fell by 37 percent. The average rate per ton-mile fell by 5 percent, to 30 mills ( 3 cents) per ton-mile. This rate was higher than for any other region examined in this report, and more than twice the national average. However, because of the high average heat content of the coal, the rate on a cents per million Btu basis was significantly below the national average. In 1993, transportation cost accounted for 27 percent of the average delivered coal price, down from 32 percent in 1988. 
Table 17. Selected Statistics for Contract Coal Shipments by Rail to Electric Utilities in the Middle Atlantic Region, 1988 and 1993

\begin{tabular}{|c|c|c|c|}
\hline Data Elemènt & 1988 & 1993 & $\begin{array}{l}\text { Percent } \\
\text { Change }\end{array}$ \\
\hline \multicolumn{4}{|l|}{ Tonnage Shipped by Rail (million short tons) } \\
\hline Compliance Coal ... & 1.5 & 1.3 & -13.3 \\
\hline Low-Sulfur Coal $\ldots \ldots \ldots \ldots \ldots \ldots \ldots \ldots \ldots \ldots \ldots \ldots \ldots \ldots \ldots$ & 2.7 & 0.2 & -92.6 \\
\hline Medium-Sulfur Coal & 6.4 & 7.4 & 15.6 \\
\hline High-Sulfur Coal . ............. & 2.9 & 4.5 & 55.2 \\
\hline 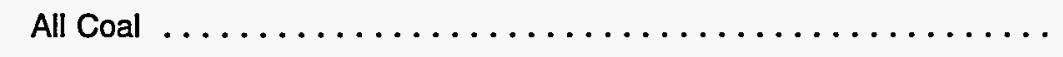 & 13.5 & 13.4 & -0.7 \\
\hline Average Distance Shipped (miles) $\ldots \ldots \ldots \ldots \ldots \ldots \ldots$ & 307.3 & 257.6 & -16.2 \\
\hline Average Transportation Rate per Million Btu (1987 cents) $\ldots \ldots \ldots \ldots$ & 51.6 & 32.4 & -37.2 \\
\hline Average Transportation Cost as a Percentage of Delivered Price ....... & 32.3 & 27.1 & -16.1 \\
\hline Average Transportation Rate per Ton-Mile (mills in 1987 dollars) .. & 31.0 & 29.6 & -4.5 \\
\hline
\end{tabular}

Notes: Compliance $=$ less than or equal to 0.6 pounds of sulfur per million Btu; Low Sulfur $=0.61$ to 1.25 pounds per million Btu; Medium Sulfur = 1.26 to 1.67 pounds per million Btu; High-Sulfur = greater than 1.67 pounds per million Btu. One mill equals 0.1 cent.

Source: Energy Information Administration, Coal Transportation Rate Data Base.

\section{East North Central Region}

The East North Central Region includes the high-sulfur coal supply (production) States of Illinois, Indiana, and Ohio along with Wisconsin and Michigan, which have sought to control sulfur dioxide emissions for many years. Changes in this region set the national trends in coal distribution, because many of the region's utilities have been substituting compliance coal for the highsulfur coal indigenous to the region. Far more coal is distributed to the region than to any other coal demand region, and electricity generating units within the region accounted for 35 percent of the nameplate capacity affected by Phase I of CAAA90.

Rail contract shipments of compliance coal to utilities in the East North Central Region rose by 39 percent between 1988 and 1993, while high-sulfur coal receipts fell by 38 percent (Table 18). The average distance of rail coal shipments to the region's utilities increased by 44 percent, to 649 miles, as compliance coal from the Powder River Basin increasingly displaced Mllinois Basin coal.

Despite this substantial increase in shipping distance, the average transportation rate per million Btu declined by 12 percent from 1988 to 1993, as rates for rail shipments from the Powder River Basin fell from about $\$ 18$ per ton in 1988 to $\$ 12$ per ton in 1993 (in constant 1987 dollars). Nevertheless, transportation cost ac- counted for 31 percent of the average delivered price in 1993, up from 25 percent in 1988, indicating that minemouth prices for this coal fell even faster than transportation rates. The average transportation rate per ton-mile declined by 43 percent, reflecting the competitiveness and dramatic productivity gains of Western railroads over this period.

\section{West North Central Region}

Utilities in the West North Central Region, which includes many of the Great Plains States, rely heavily on rail-shipped coal. Even in 1988, the region received 23 million tons of compliance coal- 63 percent of all its rail-shipped contract coal-from the Powder River Basin (Table 19). Within the region, Missouri utilities burn the most coal and are affected to the greatest extent by Phase I of the CAAA90.

In 1993, the region's utilities received about 42 million tons of compliance coal under contract by rail. This total was more than the amount received by any other demand region. Virtually all of this coal came from the Powder River Basin, while half a million tons came from the Rockies. Receipts of compliance coal grew by 80 percent between 1988 and 1993-far more than in any other demand region. By 1993, more than threefourths of the region's total rail-shipped contract coal receipts were compliance coal from the Powder River Basin. 
Table 18. Selected Statistics for Contract Coal Shipments by Rail to Electric Utilities in the East North Central Region, 1988 and 1993

\begin{tabular}{|c|c|c|c|}
\hline Data Element & 1988 & 1993 & $\begin{array}{l}\text { Percent } \\
\text { Change }\end{array}$ \\
\hline \multicolumn{4}{|l|}{ Tonnage Shipped by Rail (million short tons) } \\
\hline Compliance Coal ..... & 18.0 & 25.0 & 38.9 \\
\hline 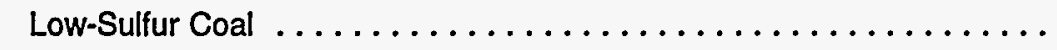 & 14.8 & 9.2 & -37.8 \\
\hline Medium-Sulfur Coal & 2.3 & 5.9 & 156.5 \\
\hline High-Sulfur Coal ...... & 28.1 & 17.4 & -38.1 \\
\hline 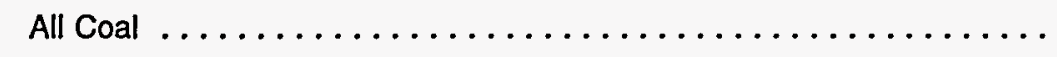 & 63.2 & 56.4 & -10.8 \\
\hline Average Distance Shipped (miles) $\ldots \ldots \ldots \ldots \ldots$ & 452.4 & 649.1 & 43.5 \\
\hline Average Transportation Rate per Million Btu (1987 cents) & 42.3 & 37.4 & -11.6 \\
\hline Average Transportation Cost as a Percentage of Delivered Price ...... & 25.4 & 30.9 & 21.7 \\
\hline Average Transportation Rate per Ton-Mile (mills in 1987 dollars) . . . . . . & 20.5 & 11.9 & -42.0 \\
\hline
\end{tabular}

Notes: Compliance $=$ less than or equal to 0.6 pounds of sulfur per million Btu; Low Sulfur $=0.61$ to 1.25 pounds per million Btu; Medium Sulfur = 1.26 to 1.67 pounds per million Btu; High-Sulfur = greater than 1.67 pounds per million Btu. One mill equals 0.1 cent.

Source: Energy Information Administration, Coal Transportation Rate Data Base.

Table 19. Selected Statistics for Contract Coal Shipments by Rail to Electric Utilities in the West North Central Region, 1988 and 1993

\begin{tabular}{|c|c|c|c|}
\hline Data Element & 1988 & 1993 & $\begin{array}{l}\text { Percent } \\
\text { Change }\end{array}$ \\
\hline \multicolumn{4}{|l|}{ Tonnage Shipped by Rail (million short tons) } \\
\hline Compliance Coal .... & 23.0 & 41.5 & 80.4 \\
\hline Low-Sulfur Coal ....... & 9.9 & 7.3 & -26.3 \\
\hline Medium-Sulfur Coal $\ldots$. & 2.4 & 2.2 & -8.3 \\
\hline High-Sulfur Coal $\ldots \ldots \ldots \ldots \ldots \ldots \ldots \ldots \ldots \ldots \ldots \ldots \ldots$ & 1.3 & 2.5 & 92.3 \\
\hline All Coal $\ldots \ldots \ldots \ldots \ldots \ldots \ldots \ldots \ldots \ldots$ & 36.6 & 53.5 & 46.2 \\
\hline Average Distance Shipped (miles) $\ldots \ldots \ldots \ldots \ldots \ldots \ldots$ & 762.2 & 806.2 & 5.8 \\
\hline Average Transportation Rate per Million Btu (1987 cents) . . . . . . . . & 64.1 & 49.6 & -22.6 \\
\hline Average Transportation Cost as a Percentage of Delivered Price ...... & 55.2 & 56.5 & 2.4 \\
\hline Average Transportation Rate per Ton-Mile (mills in 1987 dollars) . . . . . . & 14.5 & 10.8 & -25.5 \\
\hline
\end{tabular}

Notes: Compliance $=$ less than or equal to 0.6 pounds of sulfur per million Btu; Low Sulfur $=0.61$ to 1.25 pounds per million Btu; Medium Sulfur = 1.26 to 1.67 pounds per million Btu; High-Sulfur = greater than 1.67 pounds per million Btu. One mill equals 0.1 cent.

Source: Energy Information Administration, Coal Transportation Rate Data Base.

Because Powder River Basin coal was the predominant source of the region's coal throughout the period, the average shipping distance did not change much between 1988 and 1993. Partly for the same reason, the change in the average transportation rate per million Btu was smaller than for any other demand region.

Because of the low Btu value of Powder River Basin coal and the long distance the coal is shipped to utilities in the West North Central Region, the average transportation rate per million Btu is substantially higher than in any other demand region, and transportation accounts for more than half of the delivered price. Shipping distance increased slightly between 1988 and 1993, but the average transportation rate per tonmile fell by one-fourth, reflecting the decline in rail rates from the Powder River Basin. By 1993, the average rate per ton-mile reached 11 mills (1.1 cents) per ton- 
mile. This was lower than the rate in any other demand region examined, and substantially below the national average of 14 mills (1.4 cents) per ton-mile.

\section{South Atlantic Region}

The South Atlantic Region includes many of the lowsulfur coal fields of Central Appalachia, as well as encompassing the coastal States from Delaware to Florida. Railroads moved more than 70 percent of the coal distributed to the region in 1993, although barge transportation is available in parts of the region.

Electric utilities in the South Atlantic Region are by far the largest consumers of low-sulfur (as opposed to compliance) coal; they draw largely on low-sulfur coal reserves within the region. Low-sulfur coal accounted for 70 percent of the contract coal shipped to the utilities by rail in 1993, up from 59 percent in 1988
(Table 20). This increased share was not due to an increase in low-sulfur tonnage, but to a substantial decline in receipts of high-sulfur coal from Northern Appalachia. The amount of contract coal transported by rail to utilities in the South Atlantic Region fell between 1988 and 1993, due to a shift toward spot purchases and increased coal imports.

The average shipping distance increased by 19 percent between 1988 and 1993, even though reductions occurred in the amount of medium- and high-sulfur coal transported to the region from Northern Appalachia. The transportation portion of the average delivered price rose slightly, to 26 percent, even though the average transportation rate per million Btu fell by 12 percent. These figures indicate that utilities paid lower (inflation-adjusted) minemouth prices for their coal in 1993 than in 1988. The average transportation rate per ton-mile fell by 25 percent, slightly less than the national average for rail shipments of contract coal.

Table 20. Selected Statistics for Contract Coal Shipments by Rail to Electric Utilities in the South Atlantic Region, 1988 and 1993

\begin{tabular}{|c|c|c|c|}
\hline Data Element & 1988 & 1993 & $\begin{array}{l}\text { Percent } \\
\text { Change }\end{array}$ \\
\hline \multicolumn{4}{|l|}{ Tonnage Shipped by Rail (million short tons) } \\
\hline Compliance Coal ..... & 8.4 & 8.1 & -3.6 \\
\hline Low-Sulfur Coal ..... & 30.8 & 30.6 & -0.6 \\
\hline Medium-Sulfur Coal $\ldots \ldots \ldots \ldots \ldots$ & 7.0 & 4.7 & -32.9 \\
\hline High-Sulfur Coal . . . . . . . . . . . . & 6.4 & 0.3 & -95.3 \\
\hline All Coal $\ldots \ldots \ldots \ldots \ldots \ldots \ldots \ldots \ldots \ldots$ & 52.6 & 43.7 & -16.9 \\
\hline Average Distance Shipped (miles) ............. & 337.5 & 401.6 & 19.0 \\
\hline Average Transportation Rate per Million Btu (1987 cents) . . . . . . . . & 40.8 & 36.2 & -11.3 \\
\hline Average Transportation Cost as a Percentage of Delivered Price ....... & 24.2 & 26.1 & 7.9 \\
\hline Average Transportation Rate per Ton-Mile (mills in 1987 dollars) $\ldots \ldots \ldots$ & 30.5 & 22.8 & -25.2 \\
\hline
\end{tabular}

Notes: Compliance $=$ less than or equal to 0.6 pounds of sulfur per million Btu; Low Sulfur $=0.61$ to 1.25 pounds per million Btu; Medium Sulfur = 1.26 to 1.67 pounds per million Btu; High-Sulfur = greater than 1.67 pounds per million Btu. One mill equals 0.1 cent.

Source: Energy Information Administration, Coal Transportation Rate Data Base.

\section{East South Central Region}

Situated between the South Atlantic Coast States and the Mississippi River, the East South Central Region includes coal fields in three distinct areas: Central Appalachia, Southern Appalachia, and the Illinois Basin. Only 11 million tons of contract coal went to the region's utilities by rail in 1993 (Table 21); barge transportation is more important here than in the other regions, and truck transportation is also significant.

The largest share of the rail shipments (4 million tons) was compliance coal, primarily from Alabama, in Southern Appalachia. ${ }^{10}$ However, between 1988 and

${ }^{10}$ Shipments of compliance coal from the Rockies began in 1993 , but were relatively insignificant. 
Table 21. Selected Statistics for Contract Coal Shipments by Rail to Electric Utilities in the East South Central Region, 1988 and 1993

\begin{tabular}{|c|c|c|c|}
\hline Data Element & 1988 & 1993 & $\begin{array}{l}\text { Percent } \\
\text { Change }\end{array}$ \\
\hline \multicolumn{4}{|l|}{ Tonnage Shipped by Rail (million short tons) } \\
\hline Compliance Coal $\ldots \ldots \ldots \ldots \ldots \ldots \ldots \ldots \ldots \ldots \ldots \ldots \ldots \ldots \ldots$ & 3.5 & 4.3 & 22.9 \\
\hline Low-Sulfur Coal $\ldots \ldots \ldots \ldots \ldots \ldots \ldots \ldots \ldots \ldots \ldots \ldots$ & 1.1 & 3.1 & 181.8 \\
\hline Medium-Sulfur Coal $\ldots \ldots \ldots \ldots \ldots \ldots \ldots \ldots \ldots \ldots$ & 1.8 & 0.4 & -77.8 \\
\hline High-Sulfur Coal $\ldots \ldots \ldots \ldots \ldots \ldots \ldots \ldots \ldots \ldots \ldots$ & 3.0 & 3.3 & 10.0 \\
\hline 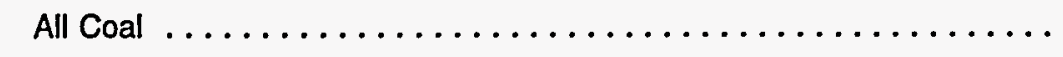 & 9.4 & 11.1 & 18.1 \\
\hline Average Distance Shipped (miles) $\ldots \ldots \ldots \ldots \ldots \ldots \ldots \ldots$ & 313.3 & 270.3 & -13.7 \\
\hline Average Transportation Rate per Million Btu (1987 cents) . . . . . . . & 26.5 & 16.7 & -37.0 \\
\hline Average Transportation Cost as a Percentage of Delivered Price ...... & 14.1 & 11.7 & -17.0 \\
\hline Average Transportation Rate per Ton-Mile (mills in 1987 dollars) . . . . . . & 19.9 & 14.7 & -26.1 \\
\hline
\end{tabular}

Notes: Compliance $=$ less than or equal to 0.6 pounds of sulfur per million Btu; Low Sulfur $=0.61$ to 1.25 pounds per million Btu; Medium Sulfur = 1.26 to 1.67 pounds per million Btu; High-Sulfur = greater than 1.67 pounds per million Btu. One mill equals 0.1 cent.

Source: Energy Information Administration, Coal Transportation Rate Data Base.

1993, low-sulfur coal shipments (also primarily from Southern Appalachia) nearly tripled. Medium-sulfur coal shipments nearly ceased, while the Illinois Basin replaced Southern Appalachia as the source of about 3 million tons of high-sulfur coal.

The average length of haul was relatively low and fell by 14 percent between 1988 and 1993. The average transportation rate per million Btu fell by 37 percent over the same period, reflecting not only the shorter average distance, but also a substantial decline in the average rate per ton-mile. The average rate per ton-mile was low compared to rates East of the Mississippi in general, probably because of stiff competition from low barge rates. Transportation cost accounted for 12 percent of the average delivered coal price in 1993-down from 14 percent in 1988, and far lower than in any other region.

\section{West South Central Region}

The West South Central Region includes Texas and Louisiana, both of which have lignite reserves. Much of the region's electricity is produced at minemouth power plants, situations in which the electric utilities control mining, transportation (usually conveyor), and power production. In 1993, 39 million tons of rail-shipped coal was delivered to power plants in the region under contracts included in the database for this report (Table 22) ${ }^{11}$ This amount was nearly the same as in 1988, and in both years, all of the contract coal shipped was compliance coal. Virtually all of this coal came from the Powder River Basin (except for about 2 million tons from the Rockies). The average shipping distance was almost 1,200 miles-longer than the distance for any other region, but a decline from 1988. Other than a significant percentage increase in shipments from the Rockies, there was little change in coal sources or types between 1988 and 1993. None of the generating units in the region are affected by Phase I of the CAAA90.

Dramatic changes occurred in rail transportation rates for shipments to the West South Central Region. The average rate per million Btu fell by 28 percent, as both the average shipping distance and the average rail rate per ton-mile declined. The rate per ton-mile was one of the lowest of any region, illustrating the low cost of long-distance rail coal transportation in the West. On average, transportation cost accounted for 54 percent of the delivered coal price in 1993, down from 64 percent in 1988. The relatively large impact of transportation cost on delivered price indicates both the low average minemouth price for Powder River Basin coal and the long distance the coal is shipped.

\footnotetext{
"In 1993, 140 million tons of coal was delivered to the West South Central Region. Of this, 133 million tons was delivered to electric utilities, and 96 million tons was delivered by rail. (Energy Information Administration, Quarterly Coal Report, October- December 1994, DOE/EIA-0121(94/4Q) (Washington, DC, May 1995), pp. 22-30.
} 
Table 22. Selected Statistics for Contract Coal Shipments by Rail to Electric Utilities in the West South Central Region, 1988 and 1993

\begin{tabular}{|c|c|c|c|}
\hline Data Element & 1988 & 1993 & $\begin{array}{l}\text { Percent } \\
\text { Change }\end{array}$ \\
\hline \multicolumn{4}{|l|}{ Tonnage Shipped by Rail (million short tons) } \\
\hline Compliance Coal ..... & 39.6 & 38.8 & -2.0 \\
\hline Low-Sulfur Coal $\ldots \ldots \ldots \ldots \ldots \ldots$ & 0 & 0 & -- \\
\hline Medium-Sulfur Coal $\ldots \ldots \ldots \ldots \ldots$ & 0 & 0 & - \\
\hline High-Sulfur Coal $\ldots \ldots \ldots \ldots \ldots \ldots \ldots \ldots \ldots \ldots \ldots \ldots \ldots \ldots$ & 0 & 0 & -- \\
\hline All Coal $\ldots \ldots \ldots \ldots \ldots \ldots \ldots \ldots \ldots \ldots \ldots$ & 39.6 & 38.8 & -2.0 \\
\hline Average Distance Shipped (miles) $\ldots \ldots \ldots \ldots \ldots \ldots \ldots \ldots$ & $1,254.6$ & $1,191.2$ & -5.1 \\
\hline Average Transportation Rate per Million Btu (1987 cents) . . . . . & 105.7 & 76.4 & -27.7 \\
\hline Average Transportation Cost as a Percentage of Delivered Price ....... & 63.5 & 53.8 & -15.3 \\
\hline Average Transportation Rate per Ton-Mile (mills in 1987 dollars) . . . . . . & 14.2 & 11.4 & -19.7 \\
\hline
\end{tabular}

Notes: Compliance $=$ less than or equal to 0.6 pounds of sulfur per million Btu; Low Sulfur $=0.61$ to 1.25 pounds per million Btu; Medium Sulfur $=1.26$ to 1.67 pounds per million Btu; High-Sulfur = greater than 1.67 pounds per million Btu. One mill equals 0.1 cent.

Source: Energy Information Administration, Coal Transportation Rate Data Base.

\section{Mountain Region}

The Mountain Region includes the important coalproducing areas of the Powder River Basin in Wyoming and Montana, the Rockies in Colorado and Utah, and the Southwest (Arizona and New Mexico). In 1993, 22 million tons of contract coal were shipped by rail from these coal-producing areas to power plants in the region (Table 23). Nearly half of this came from the Powder River Basin, while 7 million tons came from the Southwest and about 5 million tons came from the Rockies. Most of the coal was compliance coal.

Table 23. Selected Statistics for Contract Coal Shipments by Rail to Electric Utilities in the Mountain Region, 1988 and 1993

\begin{tabular}{|c|c|c|c|}
\hline Data Element & 1988 & 1993 & $\begin{array}{l}\text { Percent } \\
\text { Change }\end{array}$ \\
\hline \multicolumn{4}{|l|}{ Tonnage Shipped by Rail (million short tons) } \\
\hline Compliance Coal $\ldots \ldots \ldots \ldots$. & 12.6 & 15.0 & 19.0 \\
\hline Low-Sulfur Coal ............... & 4.4 & 6.8 & 54.5 \\
\hline Medium-Sulfur Coal $\ldots \ldots \ldots \ldots \ldots$ & 0 & 0 & -- \\
\hline High-Sulfur Coal $\ldots \ldots \ldots \ldots \ldots \ldots \ldots \ldots \ldots \ldots \ldots \ldots \ldots \ldots \ldots \ldots \ldots$ & 0 & 0 & -- \\
\hline All Coal $\ldots \ldots \ldots \ldots \ldots \ldots \ldots \ldots$ & 17.0 & 21.8 & 28.2 \\
\hline Average Distance Shipped (miles) $\ldots \ldots \ldots \ldots \ldots \ldots \ldots \ldots$ & 340.3 & 305.2 & -10.3 \\
\hline Average Transportation Rate per Million Btu (1987 cents) & 44.4 & 30.3 & -31.8 \\
\hline Average Transportation Cost as a Percentage of Delivered Price ....... & 36.1 & 29.6 & -18.0 \\
\hline Average Transportation Rate per Ton-Mile (mills in 1987 dollars) . . . . . & 25.2 & 21.7 & -13.9 \\
\hline
\end{tabular}

Notes: Compliance $=$ less than or equal to 0.6 pounds of sulfur per million Btu; Low Sulfur $=0.61$ to 1.25 pounds per million Btu; Medium Sulfur = 1.26 to 1.67 pounds per million Btu; High-Sulfur = greater than 1.67 pounds per million Btu. One mill equals 0.1 cent.

Source: Energy Information Administration, Coal Transportation Rate Data Base. 
None of the power plants in the Mountain Region are affected by Phase I of CAAA90. Other than significant growth in shipments from the Southwest and a shift from compliance to low-sulfur coal (which increased from about one-fourth to about one-third of the total), there was little change in rail-shipped contract coal distribution between 1988 and 1993. However, as in most of the other regions, there was a substantial decline in rail transportation rates. The average rate per million Btu fell by 32 percent, as both the average shipping distance and the average rate per ton-mile declined.

Most of the coal produced in the Mountain Region is shipped to electric utilities in other regions. In general, the average shipping distance for the coal mined in this region is long and the rate per ton-mile is low. However, for the coal delivered to utilities within the region, the distance is relatively short and the rate per ton-mile is high.

\section{Supply Region Comparisons for Rail Transportation}

This section examines changes from 1988 through 1993 in tonnage, sulfur content, and transportation rates for electric utility contract coal shipped by rail from each of the major coal supply regions (Figure 2, Chapter 1).

\section{Northern Appalachia}

Northern Appalachian coal deposits consist primarily of medium- to high-sulfur coal. Between 1988 and 1993, as the demand for high-sulfur coal declined, the region's rail shipments of high-sulfur contract coal to electric utilities fell by 51 percent, causing a 31-percent decline in its total rail shipments of contract coal (Table 24).

In 1993, the average distance of these rail movements was 281 miles, 22 percent longer than in 1988. Nevertheless, the average transportation rate per ton declined by 14 percent. The average rate per ton-mile fell by 30 percent over the same period, the largest decline for any of the coal supply regions. This fall may have been due to a substantial reduction in high-cost (per tonmile) short rail movements, as railroads abandoned unprofitable short lines. ${ }^{12}$ Another possible reason is that railroads were pressured to reduce rates in order to stem the decline in their shipments of high-sulfur coal.

Transportation cost accounted for 26 percent of the average delivered price for the contract coal shipped

Table 24. Selected Statistics for Utility Contract Coal Shipments by Rail Originating in Northern Appalachia, 1988 and 1993

\begin{tabular}{|c|c|c|c|}
\hline Data Element & 1988 & 1993 & $\begin{array}{l}\text { Percent } \\
\text { Change }\end{array}$ \\
\hline \multicolumn{4}{|l|}{ Tonnage Shipped by Rail (million short tons) } \\
\hline Compliance Coal ...... & 0.5 & 0.6 & 20.0 \\
\hline Low-Sulfur Coal $\ldots \ldots \ldots \ldots \ldots \ldots$ & 9.3 & 4.6 & -50.5 \\
\hline$\ldots \ldots \ldots \ldots \ldots \ldots \ldots \ldots \ldots \ldots \ldots \ldots \ldots \ldots \ldots \ldots$ & 13.5 & 13.6 & 0.7 \\
\hline High-Sulfur Coal $\ldots \ldots \ldots \ldots \ldots \ldots$ & 13.2 & 6.5 & -50.8 \\
\hline All Coal $\ldots \ldots \ldots \ldots \ldots \ldots \ldots$ & 36.5 & 25.3 & -30.7 \\
\hline Average Distance Shipped (miles) ...... & 230.5 & 280.6 & 21.7 \\
\hline Average Transportation Rate per Ton (1987 dollars) . . . . . . . . . & 9.18 & 7.91 & -13.8 \\
\hline Average Transportation Cost as a Percentage of Delivered Price ....... & 22.8 & 25.7 & 12.7 \\
\hline Average Transportation Rate per Ton-Mile (mills in 1987 dollars) $\ldots \ldots \ldots$ & 40.1 & 27.9 & -30.4 \\
\hline
\end{tabular}

Notes: Compliance $=$ less than or equal to 0.6 pounds of sulfur per million Btu; Low Sulfur $=0.61$ to 1.25 pounds per million Btu; Medium Sulfur = 1.26 to 1.67 pounds per million Btu; High-Sulfur = greater than 1.67 pounds per million Btu. One mill equals 0.1 cent.

Source: Energy Information Administration, Coal Transportation Rate Data Base.

${ }^{12}$ Generally, the rate per ton varies directly with distance and the rate per ton-mile varies inversely with distance. 
from Northern Appalachia by rail in 1993. Despite the decline in the average transportation cost, this was a higher proportion of the delivered price than in 1988, because minemouth prices for Northern Appalachia's high-sulfur fell dramatically over the period.

\section{Central Appalachia}

Central Appalachia-particularly southern West Virginia and eastern Kentucky-is the primary source of low-sulfur and compliance coals in the Eastern United States. These coal reserves are much closer than Powder River Basin compliance coals to the major coal-burning utilities of the Midwest and Southeast. However, Central Appalachian minemouth prices are substantially higher, partly because of the coal's higher Btu content and other properties that make it valuable for metallurgical production processes and for export. Also, mining costs are much higher for Central Appalachian coals than for Powder River Basin and other Western coals.

Compared with the other coal supply regions, Central Appalachia saw little change in rail-shipped contract coal distribution between 1988 and 1993 (Table 25). Overall tonnage was virtually the same, although slightly less coal was shipped to utilities in the East
North Central Region and more to utilities in the South Atlantic Region. These changes, along with new shipments to New England, resulted in a slight increase in the average distance the coal was shipped.

Changes in the cost of shipping this coal were more significant. Both the average rate per ton and the average rate per ton-mile fell by about one-fifth between 1988 and 1993. However, as minemouth coal prices fell faster than the average transportation rate per ton, transportation cost accounted for a slightly larger share of the delivered price in 1993 than in 1988.

\section{Illinois Basin}

The coal reserves of the Illinois Basin are typically high in sulfur content. High-sulfur coal accounted for 79 percent of the contract coal shipped from the region by rail in 1993 (Table 26). This share was down from 82 percent in 1988, as shipments of high-sulfur coal fell by 20 percent. Shipments to utilities in the East North Central demand region (which includes much of the Illinois Basin area) fell by 33 percent, as many of those utilities turned increasingly to Powder River Basin compliance coal. This region had more total nameplate capacity at generating units affected by Phase I of CAAA90 than any other.

Table 25. Selected Statistics for Utility Contract Coal Shipments by Rail Originating in Central Appalachia, 1988 and 1993

\begin{tabular}{|c|c|c|c|}
\hline Data Element & 1988 & 1993 & $\begin{array}{l}\text { Percent } \\
\text { Change }\end{array}$ \\
\hline \multicolumn{4}{|l|}{ Tonnage Shipped by Rail (million short tons) } \\
\hline Compliance Coal .. & 14.8 & 13.4 & -9.5 \\
\hline Low-Sulfur Coal ..... & 33.1 & 34.4 & 3.9 \\
\hline Medium-Sulfur Coal . . & * & 0.4 & -- \\
\hline High-Sulfur Coal . . . . . & 0.9 & 0 & -100.0 \\
\hline All Coal & 48.9 & 48.2 & -1.4 \\
\hline Average Distance Shipped (miles) $\ldots \ldots \ldots \ldots \ldots$ & 447.2 & 450.1 & 0.6 \\
\hline Average Transportation Rate per Ton (1987 dollars) . . . . . . . . . & 11.74 & 9.43 & -19.7 \\
\hline Average Transportation Cost as a Percentage of Delivered Price ....... & 26.3 & 26.9 & 2.3 \\
\hline Average Transportation Rate per Ton-Mile (mills in 1987 dollars) . . . & 26.0 & 20.8 & -20.0 \\
\hline
\end{tabular}

- Less than 100,000 short tons.

Notes: Compliance $=$ less than or equal to 0.6 pounds of sulfur per million Btu; Low Sulfur $=0.61$ to 1.25 pounds per million Btu; Medium Sulfur = 1.26 to 1.67 pounds per million Btu; High-Sulfur = greater than 1.67 pounds per million Btu. One mill equals 0.1 cent.

Source: Energy Information Administration, Coal Transportation Rate Data Base. 
Table 26. Selected Statistics for Utility Contract Coal Shipments by Rail Originating in the Illinois Basin, 1988 and 1993

\begin{tabular}{|c|c|c|c|}
\hline Data Element & 1988 & 1993 & $\begin{array}{l}\text { Percent } \\
\text { Change }\end{array}$ \\
\hline \multicolumn{4}{|l|}{ Tonnage Shipped by Rail (million short tons) } \\
\hline Compliance Coal ...... & 0.2 & 0.2 & 0.0 \\
\hline Low-Sulfur Coal . .................. & 3.7 & 1.2 & -67.6 \\
\hline Medium-Sulfur Coal $\ldots \ldots \ldots \ldots \ldots$. & 2.0 & 4.4 & 120.0 \\
\hline High-Sulfur Coal & 27.2 & 21.7 & -20.2 \\
\hline All Coal $\ldots \ldots \ldots \ldots \ldots \ldots \ldots \ldots$ & 33.1 & 27.5 & -16.9 \\
\hline Average Distance Shipped (miles) $\ldots \ldots \ldots \ldots \ldots \ldots \ldots \ldots \ldots$ & 113.7 & 97.0 & -14.7 \\
\hline Average Transportation Rate per Ton (1987 dollars) ....... & 3.90 & 2.87 & -26.4 \\
\hline Average Transportation Cost as a Percentage of Delivered Price ....... & 12.1 & 11.1 & -8.3 \\
\hline Average Transportation Rate per Ton-Mile (mills in 1987 dollars) . . . . . . . & 33.6 & 30.2 & -10.1 \\
\hline
\end{tabular}

Notes: Compliance $=$ less than or equal to 0.6 pounds of sulfur per million Btu; Low Sulfur $=0.61$ to 1.25 pounds per million Btu; Medium Sulfur = 1.26 to 1.67 pounds per million Btu; High-Sulfur = greater than 1.67 pounds per million Btu. One mill equals 0.1 cent.

Source: Energy Information Administration, Coal Transportation Rate Data Base.

Rail hauls of coal from Illinois Basin mines are far shorter than shipments of coal from the other supply regions. In 1993, contract coal from the Basin was shipped an average of only 97 miles by rail, down from 114 miles in 1988. Partly because of this decline in mileage, the average transportation rate per ton fell by 26 percent between 1988 and 1993. Because of the relatively short hauls, the average transportation rate (or cost) per ton was far lower than in the other coal supply regions. For the same reason, the average rate per ton-mile was higher than in any other supply region.

Finally, largely because of the short and declining average length of rail haul, transportation cost accounted for a relatively small and declining percentage of the average delivered price of the contract coal shipments from mines in the region. On average, transportation cost as a percentage of delivered price fell from 12 percent in 1988 to 11 percent in 1993.

\section{Powder River Basin}

The Powder River Basin is the Nation's premier source of compliance coal. Its abundant coal deposits are extremely thick and relatively close to the surface, making them inexpensive to mine by surface methods. Therefore, minemouth prices are low relative to prices of other coals, although this advantage is offset to some extent by the relatively low Btu content of Powder River Basin coals. Coal from the southern portion of the basin, in Wyoming, has the lowest sulfur content. Coal from the northern end of the basin, in Montana, generally has more sulfur and less heat content. Also, the transportation infrastructure is less developed in the northern end than in the southern part of the Basin.

The Powder River Basin also leads all regions in the amount of coal distributed domestically, accounting for 28 percent of the total in 1993. It also accounted for 40 percent of all coal shipped by rail to domestic consumers, as 85 percent of its coal was moved by rail.

The region stands out in many respects. Besides producing the greatest overall tonnage and the greatest compliance coal tonnage, it has the longest average shipping distance, the highest ratio of transportation cost to delivered price (on a per ton basis), and the lowest average transportation rate per ton-mile.

Powder River Basin coal producers and the railroads serving the region benefitted greatly from the increased demand for compliance coal that resulted from clean air legislation. Between 1988 and 1993, contract rail shipments of Powder River Basin compliance coal grew by 31 percent, to more than 100 million tons (Table 27). Compliance coal represented 89 percent of the coal shipped in 1993-up from 84 percent in 1988-and lowsulfur coal accounted for the remainder.

Although some Powder River Basin coal is being shipped almost to the East Coast, the average shipping 
Table 27. Selected Statistics for Utility Contract Coal Shipments by Rail Originating in the Powder River Basin, 1988 and 1993

\begin{tabular}{|c|c|c|c|}
\hline Data Element & 1988 & 1993 & $\begin{array}{l}\text { Percent } \\
\text { Change }\end{array}$ \\
\hline \multicolumn{4}{|l|}{ Tonnage Shipped by Rail (million short tons) } \\
\hline Compliance Coal .. & 80.2 & 104.8 & 30.7 \\
\hline Low-Sulfur Coal $\ldots \ldots \ldots \ldots \ldots \ldots$ & 15.3 & 12.3 & -19.6 \\
\hline Medium-Sulfur Coal & 0 & 0 &.- \\
\hline$\ldots \ldots \ldots \ldots \ldots \ldots \ldots \ldots \ldots \ldots \ldots$ & 0 & 0 & -- \\
\hline All Coal & 95.5 & 117.1 & 20.0 \\
\hline Average Distance Shipped (miles) & $1,031.6$ & $1,030.6$ & -0.1 \\
\hline Average Transportation Rate per Ton (1987 dollars) & 14.85 & 10.56 & -28.9 \\
\hline Average Transportation Cost as a Percentage of Delivered Price ....... & 58.4 & 56.2 & -3.8 \\
\hline Average Transportation Rate per Ton-Mile (mills in 1987 dollars) . . . . . . & 14.5 & 10.6 & -26.9 \\
\hline
\end{tabular}

Notes: Compliance $=$ less than or equal to 0.6 pounds of sulfur per million Btu; Low Sulfur $=0.61$ to 1.25 pounds per million Btu; Medium Sulfur = 1.26 to 1.67 pounds per million Btu; High-Sulfur = greater than 1.67 pounds per million Btu. One mill equals 0.1 cent.

Source: Energy Information Administration, Coal Transportation Rate Data Base.

distance for contract rail movements to utilities fell slightly between 1988 and 1993. The decline occurred primarily because power plants in the West North Central Region have become the principal consumers of Powder River Basin coal, whereas more distant demand regions account for a declining share of the total. In 1993, about 40 percent of the contract coal shipped by rail from the Powder River Basin went to utilities in the West North Central Region, up from about 35 percent in 1988. Between 1988 and 1993, the West North Central Region replaced the West South Central Region as the principal destination for Powder River Basin coal.

Reflecting the long average shipping distance, the average transportation rate per ton for contract coal rail shipments from the Powder River Basin is quite high, while the average rate per ton-mile is lower than in any other region. Transportation cost accounted for 56 percent of the delivered price of coal from the Powder River Basin in 1993, slightly lower than in 1988. Between 1988 and 1993, the average rate per ton fell by 29 percent and the average rate per ton-mile fell by 27 percent. This decline in transportation rates reflects the technological improvements and efficiency gains of western railroads in the face of excess coal transportation capacity, excess coal production capacity, and intense competition. Excess coal production and transportation capacity resulted from the large investments that were made after the oil crises of the 1970's and the failure of coal demand to grow as rapidly as had been expected. By 1994, however, growth in shipments led to congestion problems in the southern Powder River Basin. Substantial capacity investments are now being made in this and other areas.

\section{Rockies}

While most utilities affected by Phase I of the CAAA90 appear to be turning to the Powder River Basin for supplies of compliance coal, others are securing supplies from the Rockies-specifically, from the Uinta Basin of Colorado and Utah. Utilities in the Midwest and the Southeast have contracted for supplies of this bituminous coal, which has a higher Btu content than Powder River Basin subbituminous coal and can be burned more readily in existing boilers that were designed for bituminous coal.

Only 8 million tons of contract coal were shipped from the Rockies by rail in 1993 (Table 28), while much of the coal shipped to distant markets from this region used multimode (combined rail/barge) movements. All of the rail-shipped coal was compliance coal, and most of it (5 million tons) was hauled to utilities in the Mountain Demand Region, which includes Colorado and Utah. Nearly 2 million tons was shipped to the West South Central Region in 1993, and shipments to the East North Central Region more than doubled between 1988 and 1993 . 
Table 28. Selected Statistics for Utility Contract Coal Shipments by Rail Originating in the Rockies, 1988 and 1993

\begin{tabular}{|c|c|c|c|}
\hline Data Element & 1988 & 1993 & $\begin{array}{l}\text { Percent } \\
\text { Change }\end{array}$ \\
\hline \multicolumn{4}{|l|}{ Tonnage Shipped by Rail (million short tons) } \\
\hline Compliance Coal $\ldots \ldots \ldots \ldots \ldots \ldots$ & 6.0 & 7.7 & 28.3 \\
\hline Low-Sulfur Coal ............... & 0 & 0 & -- \\
\hline Medium-Sulfur Coal $\ldots \ldots \ldots \ldots \ldots \ldots \ldots \ldots \ldots \ldots \ldots \ldots \ldots \ldots \ldots \ldots \ldots$ & 0 & 0 & -- \\
\hline 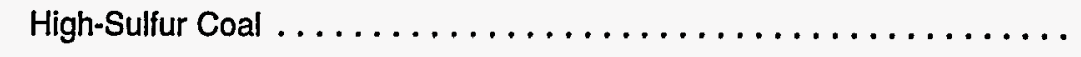 & 0 & 0 & -- \\
\hline All Coal $\ldots \ldots \ldots \ldots \ldots \ldots \ldots \ldots \ldots$ & 6.0 & 7.7 & 28.3 \\
\hline Average Distance Shipped (miles) $\ldots \ldots \ldots \ldots \ldots$ & 692.3 & 740.0 & 6.9 \\
\hline Average Transportation Rate per Ton (1987 dollars) $\ldots \ldots \ldots \ldots \ldots \ldots$ & 14.13 & 11.25 & -20.4 \\
\hline Average Transportation Cost as a Percentage of Delivered Price ....... & 37.6 & 38.9 & 3.5 \\
\hline Average Transportation Rate per Ton-Mile (mills in 1987 dollars) . . . . . . & 20.4 & 14.7 & -27.9 \\
\hline
\end{tabular}

Notes: Compliance $=$ less than or equal to 0.6 pounds of sulfur per million Btu; Low Sulfur $=0.61$ to 1.25 pounds per million Btu; Medium Sulfur = 1.26 to 1.67 pounds per million Btu; High-Sulfur = greater than 1.67 pounds per million Btu. One mill equals 0.1 cent.

Source: Energy Information Administration, Coal Transportation Rate Data Base.

Rail shipments of compliance coal from the Rockies to the Midwest are expected to increase significantly because of low backhaul rates ${ }^{13}$ offered by the Southern Pacific and the potential for rail traffic congestion in the Powder River Basin. Highly productive longwall mining methods are used in the Rockies, and the extent to which the region's markets expand will depend partly on how rapidly and for how long productivity increases. Productivity gains lower production costs, which in turn allows the coal to be sold at lower prices. $^{14}$

Even though the average shipping distance for rail movements of contract coal from the Rockies increased by 7 percent between 1988 and 1993, the average transportation rate per ton declined by 20 percent. The average rate per ton-mile fell by 28 percent. Transportation cost accounted for 39 percent of the average delivered price in 1993, almost the same proportion as in 1988.

\section{Changes for Coal Received at Phase I-Affected Boilers}

One way of examining the impact of Phase I of CAAA90 and other clean air legislation on domestic coal distribution and rail transportation rates is to compare changes in sulfur content and transportation rates for coal distributed to boilers affected by Phase I with the changes for all boilers (affected and unaffected by Phase I). For the contract coal that was shipped by rail to electric utilities, the changes for the Phase Iaffected boilers were typically much greater than the general changes.

Between 1988 and 1993, receipts of rail-shipped compliance coal at Phase I-affected boilers increased by 130 percent, while the increase for all boilers was only 27 percent (Table 29). In contrast, receipts of high-sulfur coal at Phase I-affected boilers fell by about half, while receipts at all boilers fell only one-third.

Over the same period, average shipping distance increased by 77 percent for Phase I-affected boilers, but only 11 percent for all boilers. This difference indicates that it was the Phase I-affected utilities that switched from nearby high-sulfur Northern Appalachia and Illinois Basin coals, primarily to distant Powder River Basin compliance coals. The average rail transportation rate per ton-mile fell by a greater percent for Phase Iaffected boilers, because the rate per ton-mile is much lower for long-distance unit train shipments from the Powder River Basin than it is for short-haul rail movements in the East and Midwest.

\footnotetext{
${ }^{13}$ The Southern Pacific is hauling metallurgical coal and iron ore to Geneva Steel in Provo, Utah, and offering low rates for hauling coal on the eastbound return of the trains.

${ }^{14}$ For a description, history, and economic analysis of longwall mining, see the Energy Information Administration report, Longwall Mining, DOE/EIA-TR-0588 (Washington, DC, March 1995).
} 
Table 29. Changes in Rail-Shipped Contract Coal Transportation Between 1988-1993, Phase l-Affected Boilers Compared to All Boilers

\begin{tabular}{c|c|c}
\hline Transportation Element & $\begin{array}{c}\text { Phase I- } \\
\text { Affected } \\
\text { Boilers }\end{array}$ & $\begin{array}{c}\text { All } \\
\text { Boilers }\end{array}$ \\
\hline
\end{tabular}

Compliance Coal Receipts

(million short tons)

$\begin{array}{llrr}1988 \ldots \ldots \ldots \ldots \ldots \ldots \ldots \ldots \ldots & 5.6 & 106.9 \\ 1993 \ldots \ldots \ldots \ldots \ldots \ldots \ldots \ldots \ldots & 12.8 & 135.4 \\ \text { Percent Change } \ldots \ldots \ldots \ldots \ldots \ldots & 130.0 & 26.7\end{array}$

High-Sulfur Coal Receipts

(million short tons)

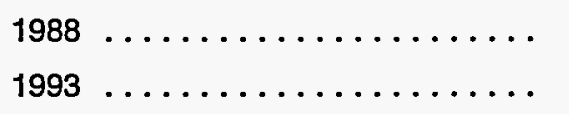

42.5

$1993 \ldots \ldots \ldots \ldots \ldots \ldots \ldots$

Percent Change ............ $\quad-52.3$

Average Shipping Distance (miles)

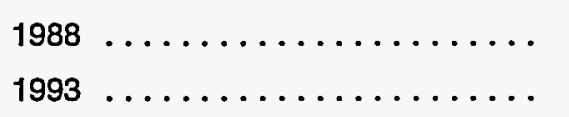

Percent Change ............

Average Transportation Rate per Ton

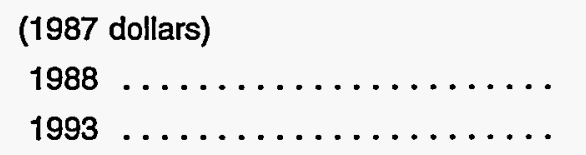

$\begin{array}{rr}6.3 & 11.1 \\ 6.1 & 8.9 \\ -4.0 & -19.4\end{array}$

Percent Change ............ $\quad-4.0 \quad-19.4$

Average Transportation Rate per

Ton-Mile (mills in 1987 dollars)

\begin{tabular}{llrr}
$1988 \ldots \ldots \ldots \ldots \ldots \ldots \ldots \ldots \ldots$ & 30.2 & 19.1 \\
$1993 \ldots \ldots \ldots \ldots \ldots \ldots \ldots \ldots \ldots \ldots$ & 15.7 & 13.6 \\
Percent Change $\ldots \ldots \ldots \ldots \ldots \ldots$ & -48.0 & -28.8 \\
\hline
\end{tabular}

Source: Energy Information Administration, Coal Transportation Rate Data Base.

However, the average rail transportation rate per ton fell by only 4 percent for the Phase I-affected boilers, compared to a 19-percent decline for all boilers. The reason is that the average shipping distance increased more for the Phase I-affected units, because they switched to distant supply sources. The longer the distance shipped, the higher was the transportation cost per ton.

\section{Summary}

Part I of this report examined changes in coal distribution and transportation rates from 1988 through 1993 (the latest year for which the necessary data were available). Before drawing conclusions from the analysis, it should be noted that 1993 was not a typical year for coal production and transportation. Miner strikes reduced production from mines in the Illinois Basin and Appalachia, leading to increased demand for Western coals. In addition, severe flooding in the Midwest disrupted normal distribution patterns.

Generally, these factors may have intensified the coal distribution changes that could be expected to result from Phase I of the CAAA90. The exact extent to which the changes described in this chapter were influenced by these extraordinary factors in 1993 is unknown. However, an examination of preliminary coal production and distribution data for 1994 and the first half of 1995 indicate that the distribution trends shown in this report not only continued through 1994, but appear to have intensified during the first half of 1995. Also, the strikes and floods should not have had much of an effect on coal transportation rates, because most of these rates had already been established by contract before these events occurred.

The increasing demand for low-sulfur coal and the declining demand for high-sulfur coal is not surprising. However, it may be surprising that electric utilities concentrated their demand on compliance coal (which meets the sulfur dioxide emissions limitations of Phase II) so soon. The demand for Powder River Basin (Wyoming) compliance coal seems to have exceeded expectations, while the demand for Central Appalachian low sulfur coal fell rather flat. Partly, these events may have been due to the strikes and floods of 1993. Partly, they may have been due to a strategy adopted by some utilities of burning compliance coal early, to build up emissions allowances for use in Phase II. Basically, however, they were largely due to the dramatic fall in western rail rates, as well as the decline in Powder River Basin coal prices.

Whatever the reasons, the Powder River Basin's share of domestic coal distribution rose from 24 percent in 1988 to 28 percent in 1993, and Central Appalachia's share increased from 23 percent to 24 percent. ${ }^{15}$ In the high-sulfur coal areas, Northern Appalachia's share fell

\footnotetext{
${ }^{15}$ Part of the shift toward low-sulfur Central Appalachian coal may have been due to low minemouth prices at some of the region's highly efficient longwall mines. For information on longwall mines, see Energy Information Administration, Longwall Mining, DOE/EIATR-0588 (Washington, DC, March 1995).
} 
from 17 percent to 14 percent, while the Illinois Basin's share fell from 15 percent to 12 percent.

Northern Appalachian producers lost market share to Central Appalachia in the Middle Atlantic demand region. Illinois Basin producers were squeezed on two sides. Primarily, they lost market share to the Powder River Basin in the East North Central and West North Central demand regions, which together accounted for 35 percent of U.S. coal receipts in 1993. They also lost market share to Central Appalachia in the South Atlantic and East South Central demand regions.

Nationwide, the average sulfur content of the coal received by electric utilities fell by 13 percent between 1988 and 1993. The largest decline-36 percent-was in the West North Central Region, where utilities shifted from high-sulfur Illinois Basin coal to Powder River Basin compliance coal. Across demand regions, the change in sulfur content was positively correlated with the amount of generating capacity affected by Phase I. That is, the greater the region's affected generating capacity, the greater was the decline in the average sulfur content of the coal burned by its utilities.

The average distance for rail shipments of contract coal increased by 11 percent between 1988 and 1993 (Figure 4). It is commonly thought that coal generally is being shipped longer distances because Powder River Basin coal is being burned by electric utilities farther and farther east of the Mississippi River. For contract coal shipped by rail, however, the average length of haul for coal from the Powder River Basin was slightly shorter in 1993 than in 1988. The average distance for shipments of compliance coal from all regions taken together increased by less than 1 percent. Apparently, the increase in average distance for all rail-shipped contract coal was due to the increasing amount of compliance coal shipped from the Powder River Basin (typically associated with long hauls) and the declining amount of high-sulfur coal shipped from the Illinois Basin (typically associated with short hauls). That is, the length of individual hauls did not increase but more coal was being shipped on long hauls, while less was being moved on short hauls.

One of the most important questions raised about the effects of CAAA90 is whether the increased demand for compliance coal and low-sulfur coal would result in higher rail transportation rates for shipments of those coals. The data analyzed in this chapter show that, as of the end of 1993, this had not happened.

Nationally, the average transportation rate per ton-mile fell by 29 percent between 1988 and 1993. This drop
Figure 4. Average Distance, Rate per Ton, and Rate per Ton-Mile for Contract Coal Rail Shipments, 1988-1993
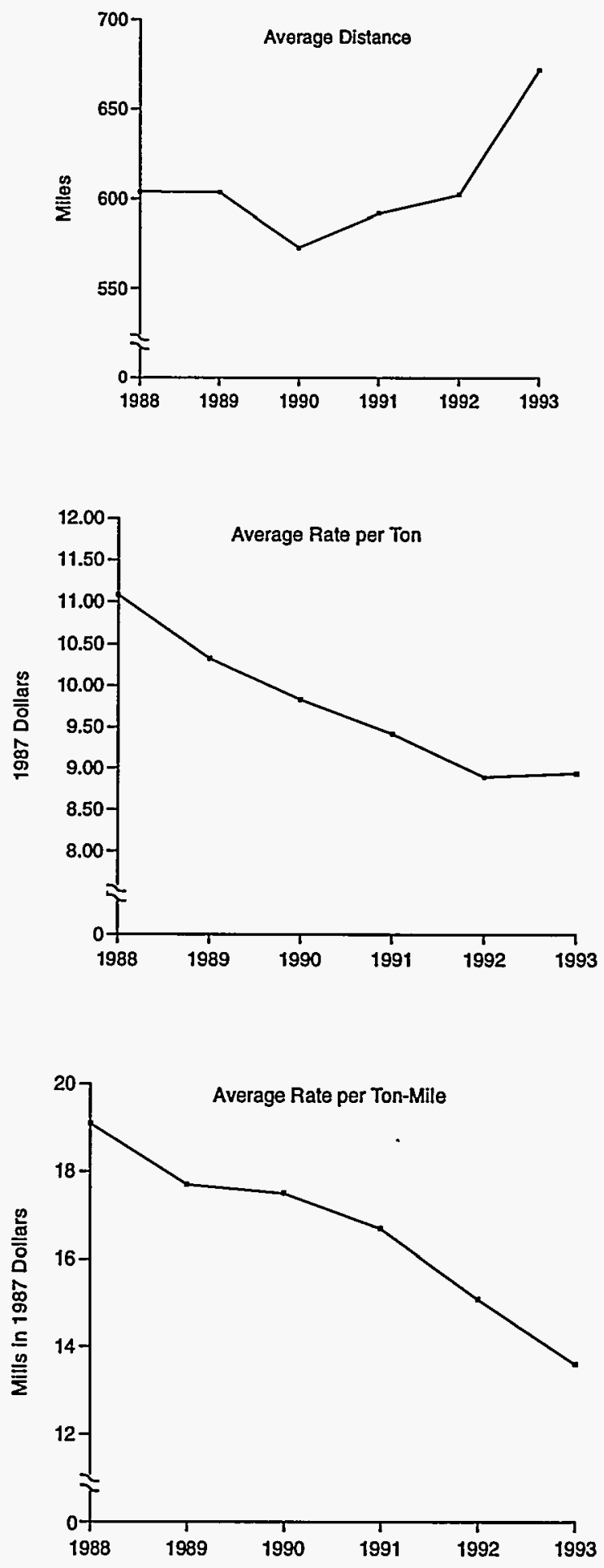

Note: One mill equals 0.1 cent.

Source: Energy Information Administration, Coal Transportation Rate Data Base 
reflects the dramatic productivity gains of railroads, particularly in the West, as well as the displacement of Illinois Basin coal (with a high average transportation cost per ton-mile) by Powder River Basin coal (with a low average rate per ton-mile). Furthermore, the average rate per ton-mile fell for each of the sulfur categories and for each of the major coal demand and supply regions.

Nationally, even though the average shipping distance increased, the average transportation rate per ton for rail-shipped contract coal fell to about four-fifths of its 1988 level. It fell for all sulfur categories (by about onefourth for compliance coal), and for every major supply region. The average transportation rate per million Btu of the coal's heating potential fell for shipments to each major demand region.

Overall, transportation cost accounted for 36 percent of the average delivered price of rail-shipped contract coal in 1993, up from 33 percent in 1988. This increase occurred because average coal prices fell by a greater percentage than did average transportation rates. The basic reason is the shift from eastern high-sulfur bituminous coals (with relatively high minemouth prices and short shipping distances) to western low-sulfur subbituminous coals (with relatively low minemouth prices and long shipping distances). For compliance coal, transportation cost as a percentage of the delivered price declined between 1990 and 1993, as transportation rates fell more than coal prices for Powder River Basin coal.

Transportation cost as a percentage of delivered price varies greatly across different coal demand and supply regions, because it is greatly influenced by shipping distance. For example, in 1993, transportation costs accounted for 57 percent of the average price for contract coal delivered to electric utilities in the West North Central Region, but for only 12 percent of the price for coal delivered to utilities in the East South Central Region. On the supply side, transportation costs accounted for 56 percent of the delivered price of coal originating in the Powder River Basin, but only for 11 percent of the delivered price of coal originating in the Illinois Basin. Between 1988 and 1993, the proportion of delivered price represented by transportation cost increased in those regions where average shipping distance increased, and decreased in those regions where average shipping distance decreased.

The changes in coal distribution and railroad transportation rates were concentrated on the electric utilities that were directly affected by Phase I of CAAA90, indicating that clean air legislation may have been the primary cause of the changes. Between 1988 and 1993, receipts of contract compliance coal at Phase I-affected units increased by 130 percent, while the increase for all boilers was only 27 percent. In contrast, the decline in high-sulfur contract coal receipts was much greater for Phase I-affected units. The average shipping distance for contract coal delivered to affected generating units increased by 77 percent, compared to an 11-percent increase for all units. Because of the greater increase in shipping distance, the average contract coal transportation cost for the units affected by Phase I fell by only 4 percent, compared to a 19-percent drop for all units.

The findings presented above indicate that the CAAA90 requirements have already had some impact on coal distribution patterns, and that they have not led to higher rail transportation rates so far (although the increased average shipping distance attenuated the decline in rail rates that resulted from efficiency gains). However, the changes in coal distribution and transportation rates described in this chapter have captured the effects of more than Phase I of CAAA90. They also reflect previous Federal and State clean air legislation. In addition, the switch from high-sulfur Northern Appalachian and Illinois Basin coals to low-sulfur Western coals may have been largely due to the falling minemouth prices and transportation rates for coal shipped from the West. Perhaps some midwestern utilities would have switched to Powder River Basin coals even without the sulfur dioxide emissions limitations of CAAA90. Changes in distribution patterns were also affected to some extent by the coal miners' strikes and floods of 1993.

In the future, other factors may have greater impacts on coal transportation than CAAA90. These include future technological improvements and productivity gains in rail transportation. Another important factor is the point at which rising demand, particularly in the Powder River Basin, will lead to rail congestion and equipment shortages that will require large investments and increased rates. ${ }^{16}$ The development of policies for

\footnotetext{
${ }^{16}$ Substantial rail congestion occurred in the southern Powder River Basin in 1994 and the first part of 1995, due to unexpectedly high coal demand. Utilities rebuilt their stockpiles after the strikes and floods of 1993, weather conditions increased the demand for electricity, and utility strategies for compliance with CAAA90 increased the demand for Powder River Basin coal. The railroads serving the region have added track, equipment, and personnel. These actions, along with cooperation among the railroads, is expected to resolve this congestion problem by the end of 1995 .
} 
limiting air toxics and carbon dioxide emissions will affect utilities' plans for compliance with Phase II of CAAA90. Finally, electric utility deregulation could result in the concentration of power production at plants with the lowest costs, shifting demand to different regions. 



\section{Part II}

\section{Electric Utility Contract Coal Transportation Trends, 1979-1993}





\section{Electric Utility Contract Coal Transportation Trends, 1979-1993}

Coal is the energy source used by electric utilities to generate more than one-half of the electricity needed in the Nation. Electric utilities accounted for 88 percent of total U.S. coal consumption in $1993 .{ }^{17}$ Because coal is the mainstay fuel of power generation and is also important to the coal transportation industry's financial wellbeing, generally it is in the interest of electric utilities, coal mining companies, and transportation firms (all of which must make substantial capital investments) to enter into long-term contracts. ${ }^{18}$ Coal supply contracts provide improved security of coal supplies, particularly when specific coal types and qualities are required. Usually, electric utilities initiate coal transportation contract negotiations with the railroads and coordinate coal supply and transportation contracts to meet the utilities' needs. Coal transportation contracts are also advantageous to utilities because they customize rate structures and services and usually provide discounts for large volumes.
Part II of this report examines national and regional trends from 1979 through 1993 in electric utility coal supply contracts, particularly in the number of contracts, the coal tonnage under contract, and the modes of transportation used to ship the coal to the utility plants. The following sections also discuss trends in the average contract duration, the average distance shipped, the average transportation rate per ton, the average transportation cost as a percentage of delivered price, and the average rate per ton-mile. Trends are examined for rail, barge, truck, and multimodal (primarily combined rail/barge) shipments, as well as for total reported contract coal shipments. Trends are examined for three coal supply regions and four coal demand regions. The regions are wider and fewer than those used in Part I of this report, to facilitate analysis of the numerous data elements, and to be consistent with an earlier Energy Information Administration report that examined utility contract coal transportation trends from 1979 through $1987 .^{19}$

\footnotetext{
${ }^{17}$ Energy Information Administration, Coal Industry Annual 1993, DOE/EIA-0584(93) (Washington, DC, December 1994$)$, p. 121.

${ }^{18}$ Transactions in which coal is obtained by the utility under purchase orders or contracts with a duration of 1 year or more are referred to as contract purchases.

${ }^{19}$ Energy Information Administration, Trends in Contract Coal Transportation 1979-1987, DOE/EIA-0549 (Washington, DC, September 1991).
} 


\section{National Trends}

The number of electric utility coal supply contracts increased by 13 percent from 1979 to 1993, with most of the increase occurring after 1987 (Table 30). The coal tonnage shipped under these contracts rose by 19 percent over the same period. It reached a peak of 458 million tons in 1991, and then fell to 418 million tons in 1993.

Table 30. Number of Utility Coal Contracts, Contract Tonnage, and Average Tonnage per Contract, 1979-1993

\begin{tabular}{|c|c|c|c|}
\hline Year & $\begin{array}{l}\text { Number of } \\
\text { Contracts }\end{array}$ & $\begin{array}{c}\text { Contract } \\
\text { Tonnage } \\
\text { (million } \\
\text { short tons) }\end{array}$ & $\begin{array}{c}\text { Average } \\
\text { Tonnage per } \\
\text { Contract } \\
\text { (thousand } \\
\text { short tons) }\end{array}$ \\
\hline 1979 & 499 & 353.7 & 708.7 \\
\hline $1980 \ldots \ldots$ & 499 & 383.1 & 767.8 \\
\hline $1981 \ldots$ & 502 & 355.4 & 707.9 \\
\hline $1982 \ldots$. & 474 & 380.0 & 801.6 \\
\hline $1983 \ldots \ldots$ & 479 & 381.6 & 796.7 \\
\hline $1984 \ldots \ldots$ & 490 & 440.6 & 899.3 \\
\hline $1985 \ldots \ldots$ & 501 & 438.7 & 875.6 \\
\hline $1986 \ldots$ & 496 & 423.0 & 852.8 \\
\hline $1987 \ldots \ldots$ & 480 & 421.7 & 878.6 \\
\hline $1988 \ldots \ldots$ & 530 & 436.1 & 822.9 \\
\hline $1989 \ldots \ldots$ & 545 & 433.6 & 795.6 \\
\hline $1990 \ldots$ & 567 & 446.4 & 787.2 \\
\hline $1991 \ldots \ldots$ & 583 & 457.7 & 785.1 \\
\hline $1992 \ldots \ldots$ & 582 & 440.8 & 757.4 \\
\hline $1993 \ldots \ldots$ & 565 & 418.0 & 739.9 \\
\hline
\end{tabular}

Source: Energy Information Administration, Coal Transportation Rate Data Base.

The average number of tons shipped per contract reached a peak of 899,000 tons in 1984 and a second peak of 879,000 tons in 1987 . This number fell steadily after 1987-at first, because the number of contracts increased and then, because the total tonnage of contract coal decreased.

\section{Trends in Transportation Modes}

When deciding the appropriate method for transporting coal from the mine to the power plant, an electric utility considers the availability of transportation facilities and transportation rates for alternative transportation modes. Service reliability is another important consideration.

Railroads hauled 55 percent of the coal distributed in the United States in 1993, and 61 percent of the coal delivered to electric utilities. ${ }^{20}$ Water transport provides the major competition to railways for long-haul shipments because it is an efficient, low-cost method of moving coal to market. About 22 percent of coal shipments to domestic consumers was shipped by water (rivers, the Great Lakes, and tidewater) in 1993. Generally, where barge transportation is available, this mode is the most economical way to transport coal. Where water transportation is not available, coal is usually shipped by railroad for long hauls and by truck for relatively short distances. The coal may be moved by conveyor or tramway rather than by truck if the power plant is near the coal mine. Also, small amounts of coal ( 5 million tons in 1993) are moved by slurry pipeline.

Railroads continued to be the principal movers of contract coal to electric utilities from 1979 through 1993, accounting for 58 percent of the total in 1993 (Table 31, Figure 5). Contract coal moved by barge steadily increased from 1988 through 1991, as barges took market share from railroads and the trucking industry. More powerplants were built with direct river access, and more waterfront facilities were constructed for coal storage and blending. Trucks' share of the contract coal market rose steadily from 1979 through 1986, then fell as contract coal shipments by rail and barge increased. The share of multimodal movements (primarily rail combined with barge) remained in the range of 8 to 11 percent between 1979 and 1993. Each of these transportation modes is discussed below.

\footnotetext{
${ }^{20}$ Energy Information Administration, Coal Industry Annual 1993, DOE/EIA-0584(93) (Washington, DC, December 1994), p. 120, and Form EIA-6, "Coal Distribution Report."
} 
Table 31. Utility Contract Coal Tonnage by Transportation Mode, 1979-1993

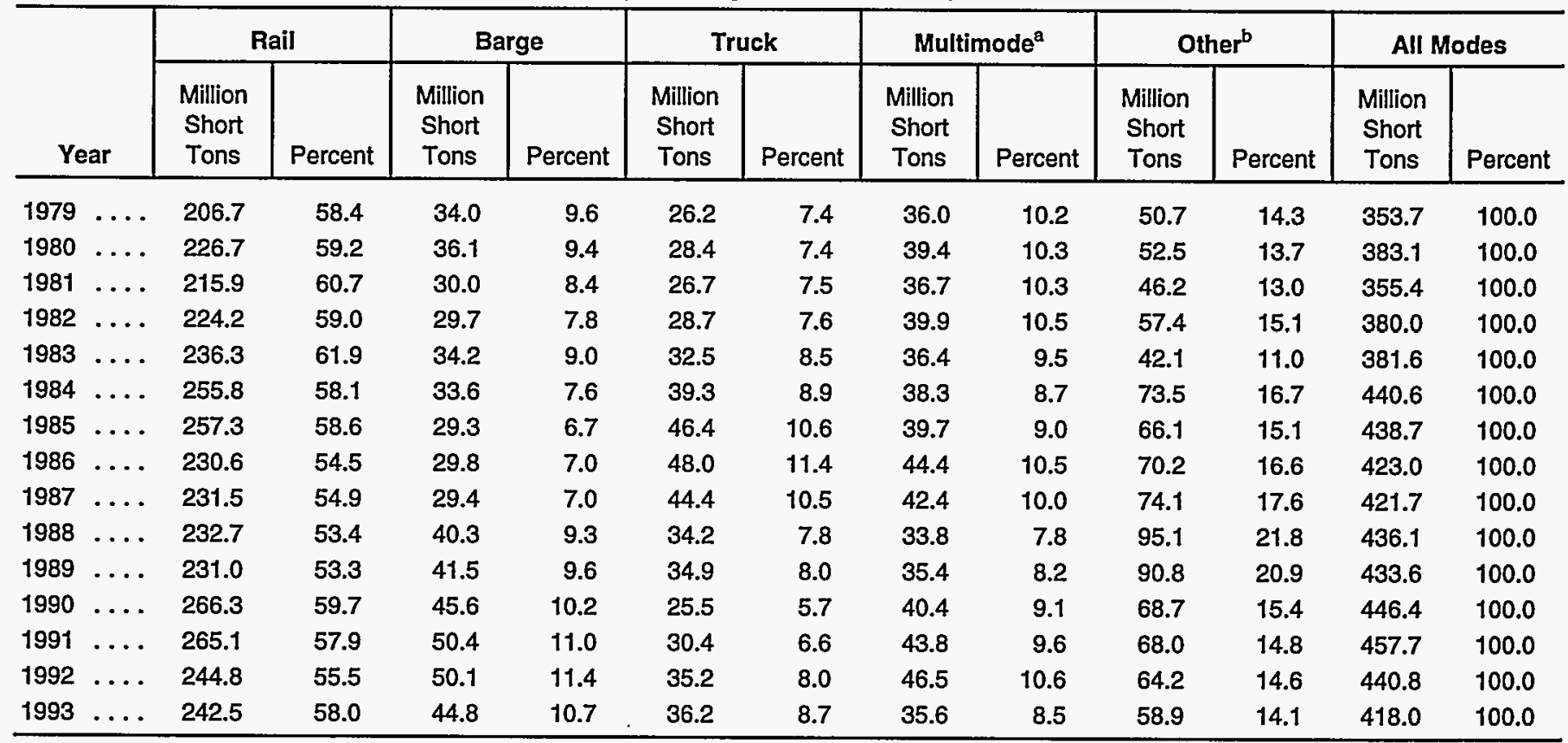

ancludes shipments that use any combination of rail, barge, and collier transportation.

bincludes conveyor, tramway, slurry pipeline, and shipments for which mode is unknown.

Source: Energy Information Administration, Coal Transportation Rate Data Base.

Figure 5. Modal Shares of Utility Contract Coal Tonnage, 1979, 1986, and 1993

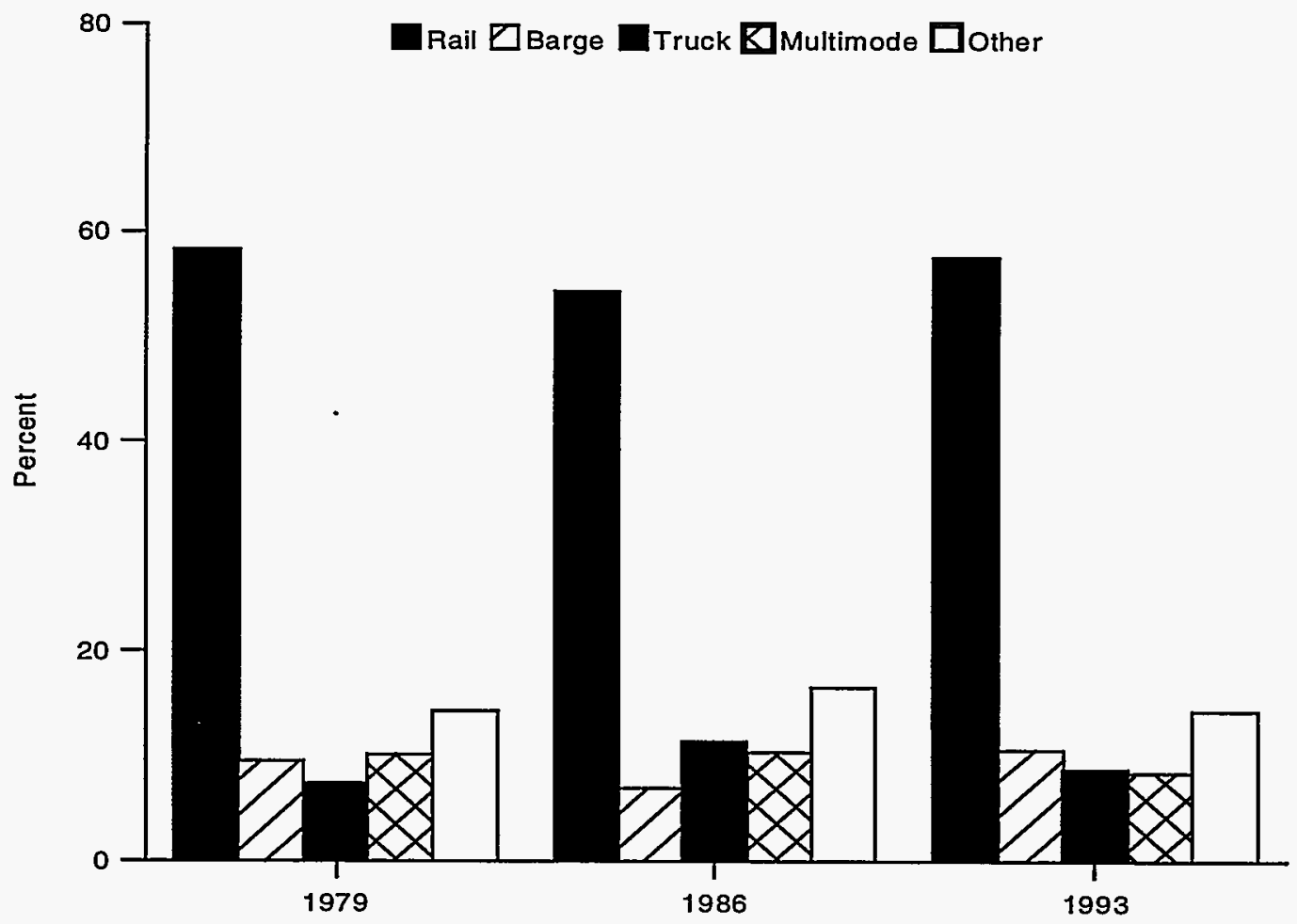

Note: "Other" includes conveyor, tramway, slurry pipeline, and shipments for which mode is unknown.

Source: Energy Information Administration, Coal Transportation Rate Data Base. 


\section{Railroads}

For the railroads, perhaps no other commodity is transported as efficiently as coal. In 1993, coal accounted for 25 percent of rail carloads, more than 38 percent of railroad tonnage, and more than 21 percent (amounting to almost $\$ 6.5$ billion) of freight revenues for Class I railroads. ${ }^{21}$

Coal is in large measure responsible for the rebirth of the railroad industry in recent years. Several factors contribute to the profitability of coal for railroads:

- Margins on coal traffic are wider than for other commodities because handling costs and related claims and insurance are far lower for coal than for other traffic. ${ }^{22}$

- Seventy-five to 80 percent of the coal transported by rail moves in highly efficient unit trains. ${ }^{23} \mathrm{~A}$ unit train can stretch for 2 miles and number 120 to 150 coal cars, carrying up to 15,000 tons. ${ }^{24}$ In 1993, unit trains accounted for 92 percent of the ton-miles for coal transportation. ${ }^{25}$

- Railroad car ownership costs have been estimated at about $\$ 1.00$ per ton. ${ }^{26}$ About 63 percent of all coal transported by rail is shipped in utility- or producer-owned cars, thereby reducing costs to the railroads. ${ }^{27}$ Utilities own or lease 30 percent of the total coal car fleet. Moreover, they often use aluminum cars, which allow heavier loadings than steel cars. All of these factors contribute to lowering rail rates.

- Utilities and coal producers have made substantial investments in efficient terminal loading and unloading facilities, which contribute to reducing railroad costs. ${ }^{28}$

- As railroads install more alternating current (AC) traction locomotives, the costs to move coal will come down further. Where heavy coal trains may require the use of five direct current locomotive units, for example, the same load can be pulled by only three AC locomotives. ${ }^{29}$

In 1993, the five largest coal-hauling railroads accounted for 85 percent of the industry's total coal movements. The industry leader, CSX Transportation, originated 1.47 million carloads of coal, or about 24 percent of total rail coal movements. Burlington Northern originated 1.368 million carloads of coal in 1993, followed by Norfolk Southern (1.116 million carloads), and Conrail (497,000 car loads). The eastern railroads' market share was hurt in 1993 by the lengthy strikes at Appalachian and Midwestern coal fields.

Although railroads were the predominant transporters of contract coal from 1979 through 1993, the amount of contract coal they shipped declined significantly in the late 1980's. The 1990's brought a rise in both the tonnage and the percentage of contract coal shipped by rail. By 1993, the railroads' share was 58 percent, virtually the same as in 1979.

\section{Barges}

The largest waterway commodity in terms of both tons transported and ton-miles hauled is coal. The inland waterway system provides about 11,000 miles of routes for shallow draft commercial vessels, and accounts for over 90 percent of U.S. internal waterborne commerce in terms of tons and ton-miles. ${ }^{30}$ Two-thirds of the power plants affected by the Clean Air Act Amendments of 1990 are located on the inland and intracoastal waterways. ${ }^{31}$

In general, tow boats push a total of 15 to 20 barges. However, a group of 15 barges must be split in order to navigate many of the smaller locks. On the other hand, in the deep waters of the lower Mississippi, 40 barges may be towed. Barges are essentially doubleskinned, steel boxes designed to be unloaded rapidly by cranes equipped with clamshell buckets or continuous belt buckets. Barges are assembled into an

\footnotetext{
${ }^{21}$ Revenues are in nominal dollars. A Class I railroad is defined as one with annual revenues greater than $\$ 92$ million. The threshold is indexed to inflation, starting from a 1978 threshold of $\$ 50$ million (Railway Age, February 1995, p. 25).

${ }^{22}$ Standard and Poor's Industry Surveys, Railroads \& Trucking (December 8, 1994), p. R19.

23"Captive Electric Utility Coal Traffic and Railroad Monopolistic Pricing," Edison Electric Institute, revised August 1985, p. 9.

${ }^{24}$ Standard \& Poor's Industry Surveys, Railroads and Trucking (December 8, 1994), p. R19.

${ }^{25}$ Based on the Interstate Commerce Commission Waybill Sample.

${ }^{26}$ Thomas Jaremko, Vice President, Marketing, GE Capital Railcars.

${ }^{27}$ Based on the Interstate Commerce Commission Waybill Sample.

${ }^{28}$ "Captive Electric Utility Coal Traffic and Railroad Monopolistic Pricing," Edison Electric Institute, revised August 1985, p. 9.

${ }^{29}$ Standard \& Poor's Industry Surveys, Railroads and Trucking (December 8, 1994), p. R19.

${ }^{30}$ U.S. Army Corps of Engineers, The 1992 Inland Waterway Review, IWR Report 92-R-7 (Fort Belvoir, VA, October 1992).

${ }^{31}$ Joe Lema, "Coal Transporters Face Rising Power Demands," Coal, August 1994, pp. 29-31.
} 
"integrated tow" with an underwater configuration similar to that of a single vessel. Barge hulls are shaped to facilitate this design. The leading barges in the towing vehicle usually have raked bows to reduce drag, and the other barges have squared bows to provide an efficient towing design. ${ }^{32}$

The chief selling point of barge service is price, which is about half that of rail service. Barges are twice as fuel-efficient as railroads and can operate with fewer crew members per haul. Additionally, barge operators spend relatively modest sums on the upkeep of their infrastructure. Barge carriers pay a user fee which contributes to the upkeep of the inland and intracoastal waterways, a task performed by the Army Corps of Engineers. Barge carriers can also achieve enormous economies of scale. For example, a coal tow can carry as much as 60,000 tons, the equivalent of as many as five unit trains. Recently, barge operators have increased their use of computer and communications technology and have cut empty tows through improved fleet management. ${ }^{33}$

Susceptibility to weather is barge transportation's chief limitation. Icing conditions limit the length of the transport season, while periodic droughts lower water depths and force cuts in tow size and lightening of loads. Floods, which were severe in 1993, can also halt or restrict barge movements. In addition, barge rates for coal transportation fluctuate with the availability of barges, which changes according to the demand for barges to haul grain. ${ }^{34}$

The amount of contract coal transported by barge increased dramatically in 1988 to 40 million tons from 29 million tons in 1987. Continuing increases, to 50 million tons in 1992, indicate that barges have taken market share from contract railroad movements. The tonnage of contract coal moved by barge (and its share of the total) fell in 1993, but this was principally due to the effects of widespread flooding. The upward trend in barge transportation is expected to resume.

\section{Trucks}

About 116 million tons of coal distributed to domestic consumers moved by truck in 1993, giving trucks a 13- percent share of the coal transportation market. ${ }^{35}$ Another 150 million tons of coal was handled by truck at some intermediate point in the distribution process, typically a haul to a preparation plant or to a transshipment point where the load continued on rail, barge, or ocean vessel. The average length of a truck haul of coal was about 50 miles, although distances could run up to 300 miles. $^{36}$

After representing a high of 11 percent of the movements of contract coal in 1986, the truck industry share fell to a low of 6 percent in 1990. Primarily, trucks lost market share to barges in the East and conveyors in the West. However, from 1990 through 1993, truck shipments of contract coal increased by 42 percent, while the tonnage shipped by each of the other modes declined. As a result, by 1993, truck shipments accounted for 9 percent of the total. Truck shipments of contract coal grew between 1990 and 1993 partly because of a shift from railroads to trucks for hauls of Illinois Basin coal to midwestern utilities.

Growth in truck transportation of coal is restricted by poor economies of longer hauls: a single truck can carry just 20 to 35 tons, compared to 100 to 120 tons per railcar. Federal regulations restrict gross vehicle weights on the interstate highway system to a maximum of 80,000 pounds. Six-axle trucks weighing up to 120,000 pounds are allowed on local roads in some States. ${ }^{37}$

\section{Multimodal Transportation}

Multimodal transportation is defined as the transportation of coal using a combination of rail and barge or rail and collier (coal ship) to move a coal shipment from the mine to an electric utility plant. Multimodal differs from intermodal transportation. Intermodal shipments are movements in a trailer or container on rail flatcars that begin or end with transport by either a motor carrier or an ocean shipping line. Intermodal freight is primarily consumer goods and light industrial products. Only a few coal shippers are utilizing rail intermodal services.

The percentage of coal transported by multimodal shipments annually ranged from 8 to 10 percent for the period from 1979 to 1993 . The tonnage shipped by

\footnotetext{
${ }^{32}$ International Atomic Energy Agency, "Railroads and Exports: Effects of Clean Air Act Amendments of 1990," (1991).

${ }^{33}$ Standard and Poor's Industry Surveys, Railroads \& Trucking (December 8, 1994), p. R20.

${ }^{34}$ Standard and Poor's Industry Surveys, Railroads \& Trucking (December 8, 1994), p. R20.

${ }^{35}$ Energy Information Administration, Coal Industry Annual 1993, DOE/ELA-0584(93) (Washington, DC, December 1994 ), p. 120.

${ }^{36}$ Standard and Poor's Industry Surveys, Railroads $\mathcal{E}$ Trucking (December 8, 1994), p. R20.

${ }^{37}$ Standard and Poor's Industry Surveys, Railroads \& Trucking (December 8, 1994), p. R19.
} 
multimodal transportation increased by 29 percent between 1979 and 1992; however, the total tonnage shipped in 1993 dropped sharply, by 23 percent, from the amount shipped in 1992. Rail-to-barge shipments are very common in the Midwest, particularly for coal coming from Illinois and Central and Northern Appalachia. A reduction in demand for high-sulfur coal from these regions, brought on by the requirements of the Clean Air Act Amendments of 1990 to reduce sulfur emissions, has significantly reduced multimodal traffic. This effect was exacerbated by the floods of 1993, which disrupted multimodal coal movements.

\section{Other Modes}

Conveyor belts (generally used at minemouth power plants), coal slurry pipelines, and tramways (used for short movements) are also methods of transporting coal. Coal moved by these methods and in shipments for which the transportation mode was unknown accounted for 14 percent of the contract coal delivered to utilities in 1993. This percentage was the same as in 1979, but lower than the peak of 22 percent in 1988. Only one coal slurry pipeline is operating in the United States, from the Black Mesa Mine in Arizona to the Mohave Generating Station in Nevada, carrying 4.8 million tons of slurry over 273 miles.

\section{Trends in Contract Duration}

The duration of a coal supply contract may range from less than 1 year to more than 30 years. For this report, contract agreements of less than 1 year are classified as spot purchases and those of 1 year or longer are classified as contract sales.

The greatest impact of railroad deregulation enacted by the Railroad Revitalization and Regulatory Reform Act of 1976 and the Staggers Rail Act of 1980 was to give railroads the ability to establish long-term contracts. During the 1980 's, railroads sought long-term contracts, quarterly rate escalation, and high minimum volumes to address the risk of the increased capital investment that was needed to improve rail transportation. $.^{38} \mathrm{De}-$ regulation of the utility industry, cogeneration, and shifts in regional coal markets resulting from the Clean Air Act Amendments of 1990 also provided new market influences and uncertainties. Railroads responded to these market forces by tailoring the terms and conditions set forth in new coal contracts to meet the customers' needs.

Market forces also had an impact on existing long-term contracts for coal transportation. Typically, the cost of contract coal is not substantially affected by short-term volatility in the coal markets caused by events such as strikes or extremely hot summers. However, in the early 1990 's, the average cost of contract coal fell due to contracts being adjusted and renegotiated to reflect current market conditions. Several reasons accounted for the continuing decrease in the delivered cost of contract coal. Some utilities found it economical to pay a fee to "buy out" older contracts and increase purchases under newer, less expensive contracts. Also, the cost of coal under some contracts is adjusted quarterly or annually according to changes in inflation-related indices, while some contracts are periodically opened for renegotiation. Because the cost of coal in general was decreasing for the past several years, renegotiation of contracts or index-related adjustments usually resulted in reductions in the cost of coal delivered under contract to electric utilities. In addition, several electric utilities were able to reduce the cost of transporting the coal to the power plant. This was often done either by renegotiation of contracts or by increasing competition among carriers. ${ }^{39}$

During the period between 1979 and 1985, more than half of the coal shipped under electric utility contracts included in the Coal Transportation Rate Date Base (CTRDB) was covered by medium-term contracts between 11 and 30 years; however, from 1986 on, the percentage of total tonnage shipped under mediumterm contracts declined as utilities switched to shortterm contracts of 10 years or less because of expectations of falling coal prices and the need for flexibility to meet the requirements of clean air legislation (Table 32). The coal shipped under long-term contracts (more than 30 years) varied from one-fourth to one-third of the total, showing no clear trend over the period from 1979 to 1993 . The percentage of total tonnage rose, for shortterm contracts, to 34 percent in 1993 from a low of 18 percent in 1983.

The average contract duration followed a cyclical pattern between 1979 and 1993, reaching a high of 24 years in 1988 and dropping to a low of 20 years in 1993 (Table 33). The average contract duration for the coal

\footnotetext{
${ }^{38}$ Kathleen M. Ferguson, Burlington Northern R.R. Co., "Railroad Marketing to the Electric Utility Customer," presented at the Electric Power Research Institute Fuel Seminar, Baltimore, MD, October 7 and 8, 1987.

${ }^{39}$ Energy Information Administration, Cost \& Quality of Fuels for Electric Utility Plants 1993, DOE/EIA-0191(93) (Washington, DC, July 1994), p. 5.
} 
Table 32. Distribution of Contract Coal Tonnage by Contract Duration, 1979-1993

\begin{tabular}{|c|c|c|c|c|c|c|c|c|}
\hline & \multirow[b]{3}{*}{ Year } & \multicolumn{6}{|c|}{ Contract Duration } & \multirow{3}{*}{$\begin{array}{c}\begin{array}{c}\text { All } \\
\text { Contracts }\end{array} \\
\begin{array}{c}\text { Tonnage } \\
\text { (million } \\
\text { short tons) }\end{array}\end{array}$} \\
\hline & & \multicolumn{2}{|c|}{$\begin{array}{c}\text { Short-Term } \\
\text { (10 Years or Less) }\end{array}$} & \multicolumn{2}{|c|}{$\begin{array}{l}\text { Medium-Term } \\
\text { (11-30 Years) }\end{array}$} & \multicolumn{2}{|c|}{$\begin{array}{c}\text { Long-Term } \\
\text { (More Than } 30 \text { Years) }\end{array}$} & \\
\hline & & $\begin{array}{l}\text { Tonnage } \\
\text { (million } \\
\text { short tons) }\end{array}$ & $\begin{array}{c}\text { Percent of } \\
\text { Total }\end{array}$ & $\begin{array}{c}\text { Tonnage } \\
\text { (million } \\
\text { short tons) }\end{array}$ & $\begin{array}{c}\text { Percent of } \\
\text { Total }\end{array}$ & $\begin{array}{c}\text { Tonnage } \\
\text { (million } \\
\text { short tons) }\end{array}$ & $\begin{array}{c}\text { Percent of } \\
\text { Total }\end{array}$ & \\
\hline 1980 & $\ldots \ldots$ & 79.7 & 20.8 & 207.3 & 54.1 & 96.2 & 25.1 & 383.1 \\
\hline 1981 & $\ldots \ldots$ & 73.5 & 20.7 & 184.7 & 52.0 & 97.3 & 27.4 & 355.4 \\
\hline 1982 & $\ldots \ldots$ & 70.1 & 18.4 & 196.5 & 51.7 & 113.4 & 29.8 & 380.0 \\
\hline 1983 & $\ldots \ldots$ & 69.2 & 18.1 & 198.1 & 51.9 & 114.3 & 30.0 & 381.6 \\
\hline 1984 & $\ldots \ldots$ & 95.4 & 21.7 & 229.0 & 52.0 & 116.2 & 26.4 & 440.6 \\
\hline 1988 & $\ldots \ldots$ & 85.2 & 19.5 & 207.2 & 47.5 & 143.7 & 33.0 & 436.1 \\
\hline 1989 & $\ldots \ldots$ & 88.8 & 20.5 & 201.0 & 46.4 & 143.8 & 33.2 & 433.6 \\
\hline 1990 & $\ldots \ldots$ & 119.2 & 26.7 & 210.1 & 47.1 & 117.0 & 26.2 & 446.4 \\
\hline 1991 & $\ldots \ldots$ & 131.7 & 28.8 & 208.5 & 45.5 & 117.6 & 25.7 & 457.7 \\
\hline 1992 & $\ldots \ldots$ & 135.4 & 30.7 & 182.1 & 41.3 & 123.3 & 28.0 & 440.8 \\
\hline 1993 & $\ldots \ldots$ & 140.1 & 33.5 & 160.1 & 38.3 & 117.9 & 28.2 & 418.0 \\
\hline
\end{tabular}

Source: Energy Information Administration, Coal Transportation Rate Data Base.

Table 33. Average Duration of Utility Coal Contracts, 1979-1993 (Years)

\begin{tabular}{|c|c|c|c|c|c|c|c|}
\hline & & Rail & Barge & Truck & Multimode $e^{b}$ & Other ${ }^{c}$ & All Modes \\
\hline 1979 & $\ldots \ldots \ldots \ldots$ & 20.3 & 21.2 & 19.4 & 16.2 & 31.1 & 21.4 \\
\hline 1980 & $\ldots \ldots \ldots \ldots$ & 20.9 & 20.3 & 20.2 & 17.3 & 31.0 & 21.8 \\
\hline 1981 & $\ldots \ldots \ldots \ldots$ & 21.4 & 19.4 & 22.4 & 18.5 & 32.3 & 22.4 \\
\hline 1982 & $\ldots \ldots \ldots$ & 21.6 & 22.0 & 22.9 & 18.3 & 32.5 & 23.0 \\
\hline 1983 & $\ldots \ldots \ldots \ldots$ & 21.8 & 22.0 & 22.4 & 19.8 & 33.2 & 23.0 \\
\hline 1984 & $\ldots \ldots \ldots \ldots$ & 22.2 & 16.1 & 25.5 & 19.0 & 20.3 & 21.4 \\
\hline 1985 & $\ldots \ldots \ldots$ & 21.8 & 15.1 & 24.6 & 18.4 & 22.5 & 21.4 \\
\hline 1986 & $\ldots \ldots \ldots$ & 21.8 & 17.1 & 26.3 & 21.3 & 20.3 & 21.7 \\
\hline 1987 & $\ldots \ldots \ldots$ & 21.4 & 17.1 & 26.1 & 21.4 & 22.1 & 21.7 \\
\hline 1988 & $\ldots \ldots \ldots$ & 22.0 & 17.6 & 28.5 & 21.0 & 28.9 & 23.5 \\
\hline $19 \dot{89}$ & $\ldots \ldots \ldots$ & 21.8 & 18.3 & 28.9 & 20.0 & 29.1 & 23.4 \\
\hline 1990 & $\ldots \ldots \ldots \ldots$ & 19.3 & 15.9 & 21.7 & 19.6 & 33.2 & 21.3 \\
\hline 1991 & $\ldots \ldots \ldots$ & 19.3 & 15.2 & 18.9 & 18.7 & 33.0 & 20.8 \\
\hline 1992 & $\ldots \ldots \ldots$ & 18.5 & 16.1 & 22.0 & 19.7 & 31.1 & 20.5 \\
\hline 1993 & $\ldots \ldots \ldots \ldots$ & 18.1 & 16.5 & 22.1 & 19.4 & 30.4 & 20.1 \\
\hline
\end{tabular}

Includes shipments that use any combination of rail, barge, and collier transportation.

bincludes conveyor, tramway, slurry pipeline, and shipments for which mode is unknown.

Note: Average duration refers to utility coal supply (not transportation) contracts and is weighted by tonnage shipped.

Source: Energy Information Administration, Coal Transportation Rate Data Base. 
moved by rail followed the same pattern. The average contract duration for barge shipments declined and was lower than for any other transportation mode after 1984. On the other hand, the average duration of coal supply contracts for the coal moved by truck increased from 19 to 29 years between 1979 and 1989. Then it dropped sharply to 22 years in 1990 and remained near that level through 1993.

\section{Trends in Shipping Distance}

After several years of oscillation, the average distance contract coal was shipped increased by 32 percent between 1987 and 1993 (Figure 6). Much of that increase occurred in 1992 and 1993 when the average distance rose due to a large increase in the demand for Western low-sulfur coal, which often is shipped long distances to utilities affected by the Clean Air Act Amendments of 1990. Basically, these changes reflected the long-term upward trend in the average distance of rail shipments, which rose by 40 percent between 1979 and 1993 (Table 34). The large increase in average distance in 1993 also was partly due to the severe floods of 1993, which necessitated some circuitous routing.

The average distance for coal shipped by barge reached its highest level in 1987. Then it fell by 22 percent between 1987 and 1993, partly because of a decrease in the amount of contract coal shipped by barge from Illinois Basin mines to power plants in the South.

The average distance for truck shipments varied from year to year, but there was a long-term downward trend. Between 1979 and 1993, the average distance for

Figure 6. Average Distance Shipped per Ton for Utility Contract Coal Tonnage by Transportation Mode, 1979-1993

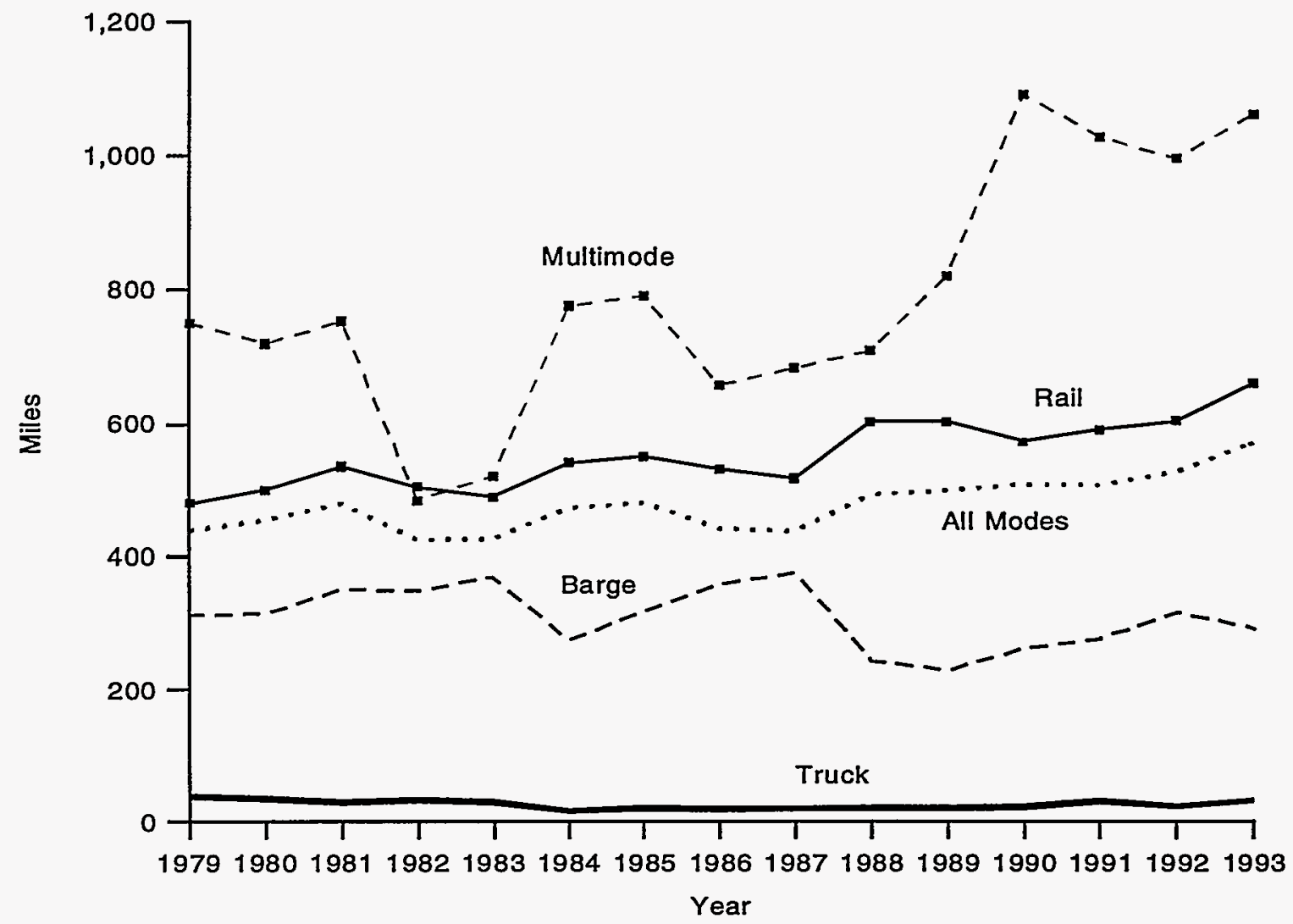

Source: Energy Information Administration, Coal Transportation Rate Data Base. 
Table 34. Average Distance Shipped per Ton for Utility Contract Coal by Transportation Mode, 1979-1993 (Miles)

\begin{tabular}{|c|c|c|c|c|c|c|c|}
\hline & Year & Rail & Barge & Truck & Multimode $\mathrm{a}^{\mathrm{a}}$ & Other ${ }^{b}$ & All Modes \\
\hline 1979 & $\ldots$ & 479.2 & 313.5 & 38.2 & 751.2 & 47.5 & 437.7 \\
\hline 1980 & $\ldots \ldots \ldots \ldots$ & 499.4 & 314.1 & 35.0 & 720.1 & 52.5 & 453.7 \\
\hline 1981 & $\ldots \ldots \ldots \ldots$ & 534.5 & 351.5 & 29.5 & 753.4 & 57.7 & 478.4 \\
\hline 1982 & $\ldots \ldots \ldots \ldots$ & 503.7 & 349.6 & 32.8 & 483.5 & 61.4 & 423.6 \\
\hline 1983 & $\ldots \ldots \ldots \ldots$ & 488.7 & 369.7 & 29.0 & 520.3 & 83.8 & 425.9 \\
\hline 1984 & $\ldots \ldots \ldots \ldots$ & 539.9 & 275.1 & 15.9 & 776.1 & 32.0 & 472.4 \\
\hline 1985 & $\ldots \ldots \ldots \ldots$ & 550.0 & 318.2 & 20.3 & 791.1 & 32.0 & 480.1 \\
\hline 1986 & • & 530.6 & 359.2 & 18.8 & 658.0 & 63.9 & 441.1 \\
\hline 1987 & $\ldots \ldots \ldots$ & 517.0 & 376.4 & 20.0 & 684.0 & 49.4 & 437.3 \\
\hline 1988 & $\ldots \ldots \ldots \ldots$ & 603.8 & 243.8 & 21.0 & 709.9 & 70.8 & 492.0 \\
\hline 1989 & $\ldots \ldots \ldots$ & 603.7 & 229.2 & 20.6 & 821.1 & 65.8 & 498.8 \\
\hline 1990 & $\ldots$ & 572.6 & 262.2 & 21.9 & $1,090.8$ & 40.0 & 507.9 \\
\hline 1991 & $\ldots \ldots \ldots$ & 591.7 & 277.1 & 31.1 & $1,027.6$ & 41.7 & 506.6 \\
\hline 1992 & $\ldots \ldots \ldots \ldots$ & 602.4 & 317.2 & 23.0 & $1,015.5$ & 58.7 & 529.1 \\
\hline 1993 & $\ldots \ldots \ldots$ & 671.3 & 292.8 & 32.0 & $1,053.5$ & 63.2 & 576.1 \\
\hline
\end{tabular}

ancludes shipments that use any combination of rail, barge, and collier transportation.

bincludes conveyor, tramway, slurry pipeline, and shipments for which mode is unknown.

Source: Energy Information Administration, Coal Transportation Rate Data Base.

truck shipments fell by 16 percent. As small producers have left an industry where much of the coal moved by truck came from small producers, an increasing portion of truck hauls have transported coal to barge loading points. ${ }^{40}$ The increase in truck shipment distance in 1993 may have been due to the heavy floods, which caused some substitution of truck for barge transportation.

In 1993, the average distance for multimodal contract coal shipments was 1,054 miles, which was about 40 percent greater than in 1979. Partly, this increase was due to the increased rail/barge shipments from Western (primarily Powder River Basin) mines to power plants in the Midwest and South.

\section{Trends in Transportation Rates}

Coal transportation rates often are a significant factor in determining the profitability of a particular coal region. Low rates can expand market penetration into new areas, and conversely, high rates can prompt utility consumers to look to competing coal regions, while consumers with dual-fired boilers may consider switching to natural gas. ${ }^{41}$ Utilities have also secured rate reductions through credible threats to build rail spurs that would give them access to a competing railroad or barge connection. Competition (whether from another railroad, another transportation mode, or a different coal source), the possibility of a load to haul back to the origination point, and the ability to handle additional business are all factors affecting coal transportation rates. The transportation rate also depends on whether or not the utility provides transportation equipment, such as coal cars.

\section{Trends in Average Rate per Ton}

Even though, on average, contract coal was shipped nearly one-third farther in 1993 than in 1979, the average cost of shipping that coal fell by 23 percent, from $\$ 10.11$ to $\$ 7.83$ per ton (Table 35, Figure 7). Between its 1984 peak and 1993, the average transportation rate per ton fell by 34 percent, due to the beneficial impact of transportation deregulation on efficiency and productivity, increasing competition for electric utility coal contracts, and increasing intra- and intermodal transportation competition. Generally, transportation rates fell for each transportation mode.

\footnotetext{
${ }^{40}$ Standard \& Poor's, Industry Surveys, Railroads and Trucking, (November 4, 1993), p. 70.

${ }^{41}$ Coal Transportation Report (Washington: Fieldston Publications, Inc., March 20, 1995), p. 8.
} 
Table 35. Average Utility Contract Coal Transportation Rate per Ton by Transportation Mode, 1979-1993 (1987 Dollars per Short Ton)

\begin{tabular}{|c|c|c|c|c|c|c|c|}
\hline & Year & Rail & Barge & Truck & Multimode ${ }^{a}$ & Other & All Modes \\
\hline 1979 & & 10.80 & 2.73 & 6.85 & 16.00 & 2.63 & 10.11 \\
\hline 1980 & $\ldots \ldots \ldots$ & 11.21 & 2.91 & 6.50 & 16.58 & 2.18 & 10.38 \\
\hline 1981 & $\ldots \ldots \ldots$ & 12.22 & 3.89 & 8.08 & 17.12 & 2.65 & 11.48 \\
\hline 1982 & $\ldots \ldots \ldots$ & 12.36 & 3.51 & 6.58 & 14.73 & 2.55 & 11.14 \\
\hline 1983 & $\ldots \ldots \ldots$ & 12.48 & 3.68 & 5.31 & 16.80 & 3.44 & 11.33 \\
\hline 1984 & $\ldots \ldots \ldots$ & 13.31 & 5.00 & 5.49 & 19.54 & 2.18 & 11.84 \\
\hline 1985 & $\ldots \ldots \ldots$ & 12.04 & 3.19 & 3.42 & 18.14 & 1.73 & 10.72 \\
\hline 1986 & $\ldots \ldots \ldots$ & 11.00 & 2.88 & 4.31 & 13.61 & 2.74 & 9.45 \\
\hline 1987 & $\ldots \ldots \ldots$ & 10.31 & 2.85 & 4.03 & 11.82 & 2.85 & 8.65 \\
\hline 1988 & $\ldots \ldots \ldots$ & 11.08 & 2.70 & 3.44 & 16.33 & 3.13 & 10.01 \\
\hline 1989 & $\ldots \ldots \ldots$ & 10.33 & 2.79 & 3.02 & 15.73 & 4.14 & 9.43 \\
\hline 1990 & $\ldots \ldots \ldots$ & 9.83 & 2.24 & 3.71 & 12.92 & 1.65 & 8.56 \\
\hline 1991 & .......... & 9.41 & 2.27 & 4.06 & 11.68 & 1.61 & 8.04 \\
\hline 1992 & $\ldots \ldots \ldots$ & 8.89 & 3.04 & 3.64 & 10.85 & 1.81 & 7.83 \\
\hline 1993 & $\ldots \ldots \ldots$ & 8.93 & 2.81 & 3.56 & 10.63 & 1.88 & 7.83 \\
\hline
\end{tabular}

ancludes shipments that use any combination of rail, barge, and collier transportation.

Source: Energy Information Administration, Coal Transportation Rate Data Base.

Figure 7. Average Utility Contract Coal Transportation Rate per Ton by Transportation Mode, 1979-1993

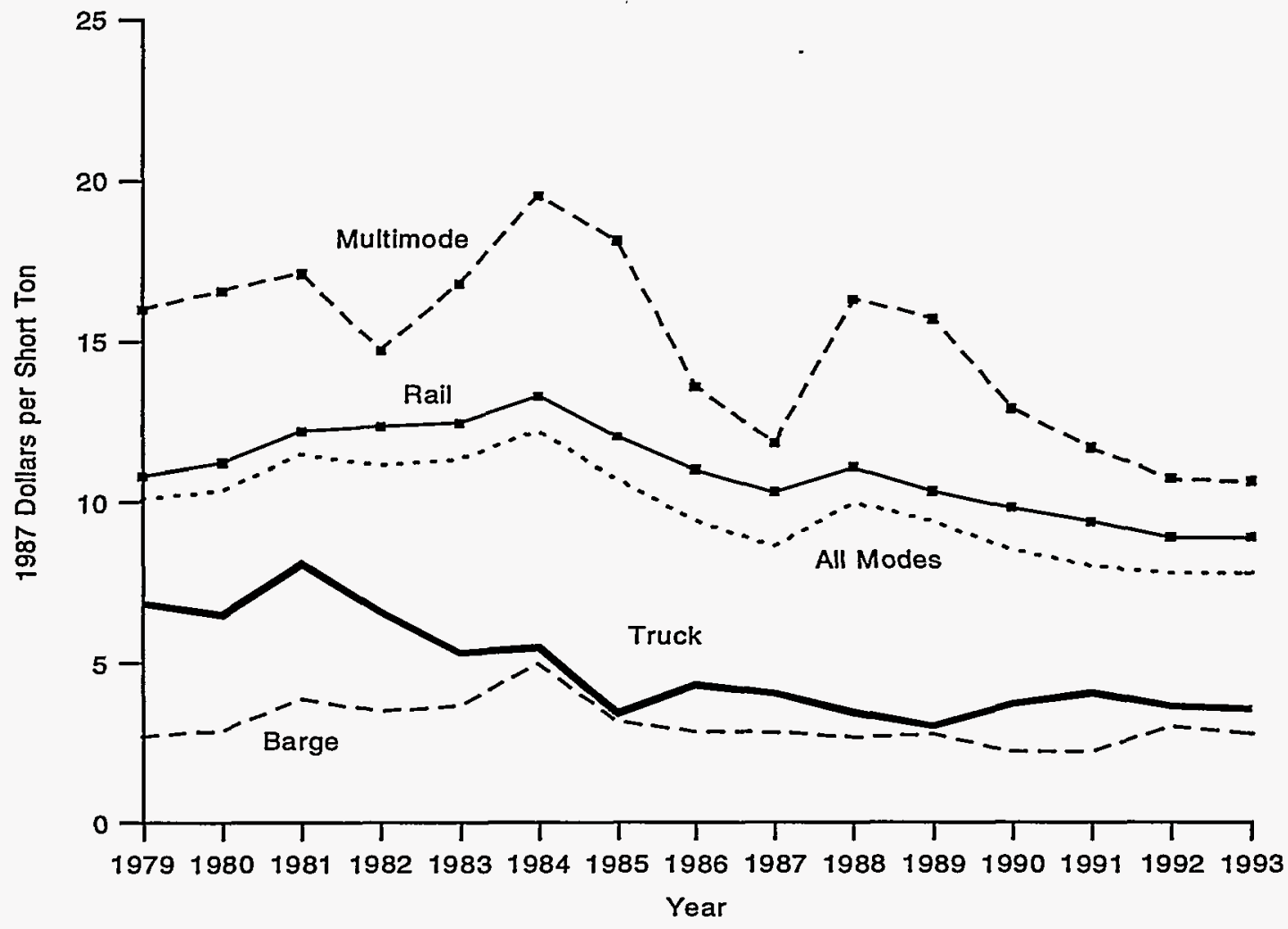

Source: Energy Information Administration, Coal Transportation Rate Data Base. 
Over the past few decades, numerous railroads merged to create new single-line, long-haul corridors. These mergers, which involved merging rail systems "end-toend," made traffic movements faster and more reliable by reducing switching from one line to another and cut freight rates by eliminating circuitous joint hauls, which inflate costs and lengthen transit times. Today's mergers, primarily undertaken to attract more freight by offering extended single-line hauls, permit some nearterm cost savings. ${ }^{42}$

Changes in average transportation costs are of interest primarily because they affect the delivered price of coal. During 1979 through 1993, the cost of transporting contract coal to the utilities accounted for 25 to 31 percent of the delivered price (Table 36, Figure 8). In 1988, the average transportation cost rose sharply, to 31 percent of the average delivered price, because of an increase in the average distance the coal was shipped. It remained near that level through 1993, as delivered coal prices fell at about the same rate as transportation cost.

\section{Table 36. Utility Contract Coal Transportation Cost as a Percentage of Delivered Price, 1979-1993}

\begin{tabular}{|c|c|c|}
\hline & Year & Percent \\
\hline 1979 & $\ldots \ldots \ldots \ldots \ldots \ldots$ & 24.9 \\
\hline 1980 & $\ldots \ldots \ldots \ldots \ldots \ldots \ldots$ & 25.2 \\
\hline 1981 & $\ldots \ldots \ldots \ldots \ldots \ldots \ldots$ & 27.3 \\
\hline 1982 & $\ldots \ldots \ldots \ldots \ldots \ldots \ldots$ & 25.6 \\
\hline 1983 & $\ldots \ldots \ldots \ldots \ldots \ldots$ & 27.2 \\
\hline 1984 & $\ldots \ldots \ldots \ldots \ldots \ldots$ & 29.0 \\
\hline 1985 & $\ldots \ldots \ldots \ldots \ldots$ & 26.6 \\
\hline 1986 & $\ldots \ldots \ldots \ldots \ldots$ & 25.3 \\
\hline 1987 & $\ldots \ldots \ldots \ldots \ldots \ldots \ldots$ & 25.0 \\
\hline 1988 & $\ldots \ldots \ldots \ldots \ldots \ldots \ldots \ldots$ & 30.7 \\
\hline 1989 & $\ldots \ldots \ldots \ldots \ldots \ldots$ & 30.7 \\
\hline 1990 & $\ldots \ldots \ldots \ldots \ldots \ldots$ & 28.9 \\
\hline 1991 & $\ldots \ldots \ldots \ldots \ldots \ldots$ & 28.3 \\
\hline 1992 & $\ldots \ldots \ldots \ldots \ldots \ldots$ & 29.4 \\
\hline 1993 & $\ldots \ldots \ldots \ldots \ldots \ldots$ & 31.2 \\
\hline
\end{tabular}

Source: Energy Information Administration, Coal Transportation Rate Data Base.

\section{Trends in Average Rate per Ton-Mile}

As shown above, the average transportation rate per ton for contract coal fell significantly between 1979 and
1993, even though the average shipping distance increased. This decrease was possible only because of a decline in the average rate per ton-mile, or the cost of transporting each ton of coal per mile of movement. Between 1979 and 1993, the average rate per ton-mile for contract coal shipments fell by 42 percent (Table 37 ). One reason for the decline was the increase in the average shipping distance. Generally, as shipping distance increases, the average transportation cost per ton-mile declines because fixed costs that do not vary with distance (such as administrative costs) are spread over a greater number of ton-miles.

Another important reason for the decline in the average rate per ton-mile was the significant increase in competition in the railroad and trucking industries in the 1980 's, following their deregulation. In particular, the railroads rationalized their structure by selling or abandoning unprofitable lines, undertaking mergers that made coal movements more efficient, and reducing their personnel. These actions led to productivity increases that allowed the railroads to reduce rates. In the 1990 's, measures to increase productivity and reduce costs turned toward technological advancements in locomotives and coal cars (allowing more coal to be hauled by fewer locomotives), improvements in equipment and track utilization, faster unloading, and improvements in communications and coordination.

Cost cutting in coal transportation between 1988 and 1993 was spurred by the existence of excess capacity in the coal mining and coal transportation industries, combined with the increasing pressure on electric utilities to control their costs by searching for low-cost coal supplies. The predominant strategy of the railroads was to reduce their rates so that coal producers could ship coal to more distant markets and increase the amount of coal delivered to electric utilities.

The decline in coal transportation rates (and the increase in the shipping distance) was greatest for coal shipped from Western coal mines. Partly because of reductions in minemouth coal prices and coal transportation rates, and partly because of the increased demand for low-sulfur coal that resulted from the Clean Air Act Amendments of 1990, Western coal is being shipped to 23 States, compared to 15 States in 1980. Coal transportation rates from the Powder River Basin are about half of what they were in the $1970{ }^{\prime} \mathrm{s}^{43}$

Between 1979 and 1993, the average rate per ton-mile fell for all transportation modes. The greatest decline

\footnotetext{
${ }^{42}$ Standard and Poor's Industry Surveys, Railroads \& Trucking (December 8, 1994), p. R15.

${ }^{43}$ Speech by Nick Moros, Senior Vice President of Sales and Marketing, Cyprus Amax Coal, reported in Coal Outlook, October 10, 1994, pp. 1, 2.
} 


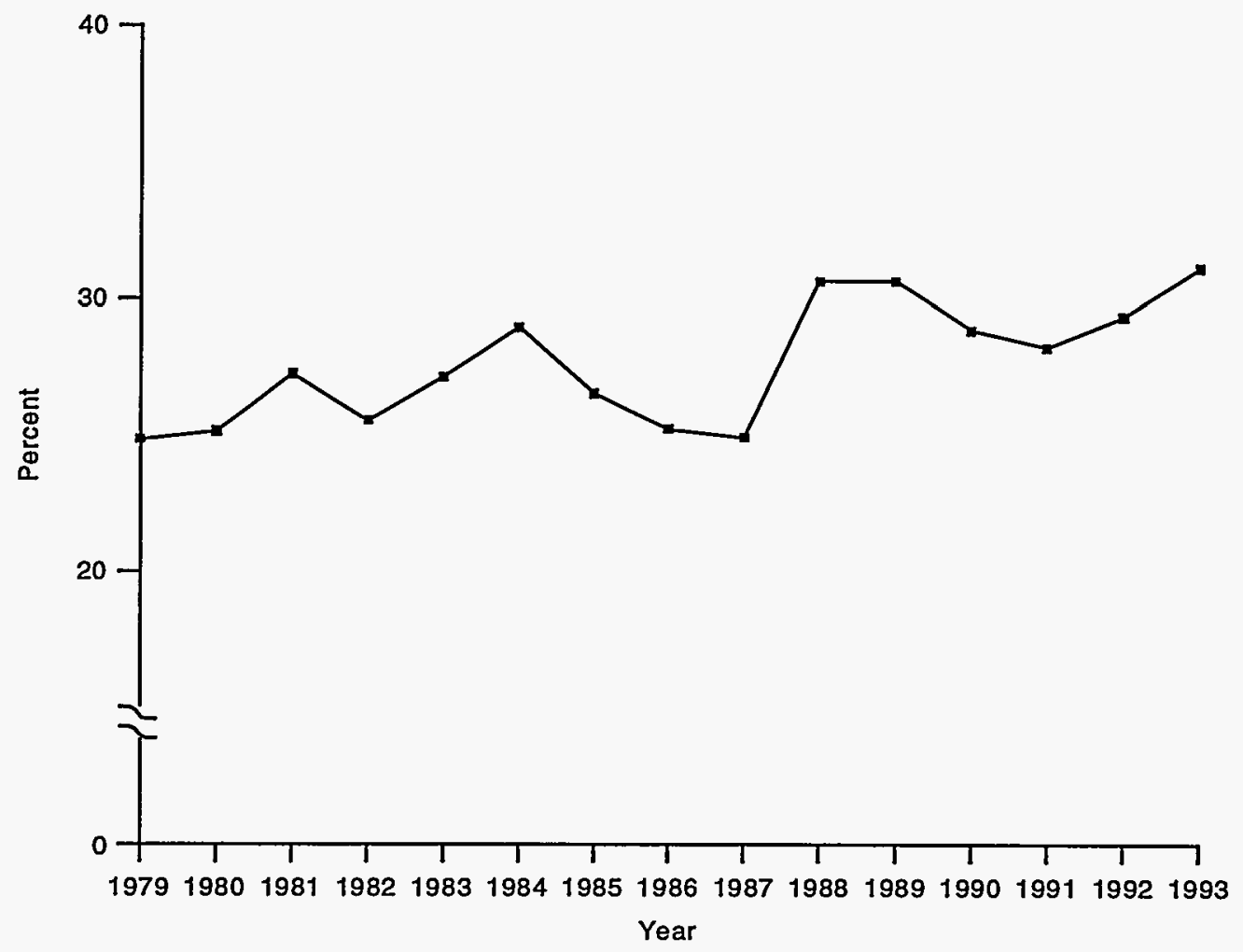

Source: Energy Information Administration, Coal Transportation Rate Data Base.

Table 37. Average Utility Contract Coal Transportation Rate per Ton-Mile by Transportation Mode, 1979-1993 (Mills in 1987 Dollars)

\begin{tabular}{|c|c|c|c|c|c|c|c|}
\hline & Year & Rail & Barge & Truck & Multimode $^{\mathrm{a}}$ & Other & All Modes \\
\hline 1979 & $\ldots \ldots$ & 22.4 & 12.2 & 99.5 & 21.4 & 32.1 & 22.1 \\
\hline 1980 & $\ldots \ldots \ldots \ldots \ldots$ & 22.6 & 12.4 & 98.0 & 22.5 & 30.7 & 22.5 \\
\hline 1981 & $\ldots \ldots \ldots \ldots \ldots$ & 23.2 & 14.7 & 130.1 & 22.6 & 32.2 & 23.1 \\
\hline 1982 & $\ldots \ldots \ldots \ldots$ & 24.7 & 13.7 & 118.0 & 30.4 & 24.9 & 25.5 \\
\hline 1983 & $\ldots \ldots \ldots \ldots$ & 24.7 & 14.2 & 120.6 & 30.5 & 21.1 & 25.3 \\
\hline 1984 & $\ldots \ldots \ldots \ldots$ & 26.2 & 19.6 & 291.8 & 24.1 & 38.5 & 26.1 \\
\hline 1985 & $\ldots \ldots \ldots \ldots \ldots$ & 23.4 & 10.6 & 117.1 & 23.1 & 38.1 & 23.0 \\
\hline 1986 & $\ldots \ldots \ldots \ldots$ & 23.6 & 9.7 & 173.5 & 24.5 & 19.6 & 23.7 \\
\hline 1987 & $\ldots \ldots \ldots \ldots \ldots$ & 22.5 & 9.2 & 162.0 & 22.0 & 27.6 & 22.6 \\
\hline 1988 & $\ldots \ldots \ldots \ldots \ldots$ & 19.1 & 9.0 & 158.1 & 19.3 & 17.9 & 18.9 \\
\hline 1989 & $\ldots \ldots \ldots \ldots \ldots$ & 17.7 & 9.9 & 149.3 & 16.8 & 27.2 & 17.6 \\
\hline 1990 & $\ldots \ldots \ldots \ldots \ldots$ & 17.5 & 8.2 & 146.7 & 12.1 & 27.0 & 16.3 \\
\hline 1991 & $\ldots \ldots \ldots \ldots$ & 16.7 & 7.8 & 97.1 & 11.3 & 25.1 & 15.4 \\
\hline 1992 & $\ldots \ldots \ldots \ldots$ & 15.1 & 8.1 & 109.8 & 10.6 & 24.1 & 13.9 \\
\hline 1993 & $\ldots \ldots \ldots \ldots \ldots$ & 13.6 & 8.0 & 84.2 & 10.0 & 21.6 & 12.9 \\
\hline
\end{tabular}

Includes shipments that use any combination of rail, barge, and collier transportation.

Note: One mill equals 0.1 cent. In computing the average rate per ton-mile, shipments for which the rate, distance, or tonnage was not reported were not used. Therefore, the average in this table cannot be replicated by using the summary information in Tables 5 and 6 , which utilized all available data.

Source: Energy Information Administration, Coal Transportation Rate Data Base. 
(53 percent) was for multimodal shipments, partly because the average shipping distance increased more for this category than for any other transportation mode. In addition, there were substantial improvements in the methods and equipment for transferring coal from rail cars to barges.

\section{Summary}

As minemouth coal prices declined and electric utilities turned toward more distant sources (particularly the Powder River Basin) for low-sulfur coal, the importance of coal transportation costs increased. In 1993, coal transportation costs represented 31 percent of the average delivered price of the contract coal shipped to electric utilities, compared with 25 percent in 1979.

Of the 418 million tons of contract coal delivered to electric utilities in 1993, 58 percent was delivered by rail and 11 percent by barge. Truck hauls and multimodal (principally rail/barge) movements each accounted for 9 percent of the total. Of the remainder, most was moved from the mine to the power plant by conveyor. Generally, between 1979 and 1993, railroads lost a small part of their market share to barges and trucks.

Between 1979 and 1993, largely because of increased shipments of Powder River Basin coal to midwestern power plants, the average shipping distance for contract coal rose by 32 percent, to 576 miles. Multimodal movements increased by 40 percent, to 1,054 miles.

Despite this increase in shipping distance, the average cost for transporting each ton of contract coal fell by 23 percent between 1979 and 1993. As shipping distance increased, the average transportation cost per ton-mile (i.e., the average cost of shipping one ton one mile) declined by 42 percent. Basically, the fall in coal transportation costs was due to the emergence of strong competition among transporters (especially railroads), among different transportation modes, and among coal producers in various coal-producing regions. Strong competition led to technological and organizational improvements that increased efficiency and productivity, leading to lower costs and lower rates. 


\section{Regional Comparisons}

The national coal transportation trends discussed in the previous chapter result from, but mask, different coal production, consumption, and transportation trends in various parts of the Nation. This chapter uses the Coal Transportation Rate Data Base (CTRDB) to reveal significant regional differences in electric utility contract coal transportation methods, contract duration, distance shipped, transportation rates, and transportation trends.

Comparisons are made for four broad coal demand regions (Northeast, Midwest, South, and West), each a combination of several Census Divisions (Figure 9). Each demand region's CTRDB statistics represent the coal that was delivered to that region, and the regions may be viewed as coal consumption regions. Comparisons are also made for three coal supply regions (Appalachia, Interior, and Western), which group the major U.S. coalfields. Generally, the statistics for these supply regions represent the coal shipments that originated in the region, and the regions may be viewed as coal production regions. For both the demand and the supply regions, the statistics are compared for 1979, 1986, and 1993, to capture regional trends.

\section{Demand Regions}

The Midwest was the destination for more of the contract coal included in the CTRDB than any other demand region. In 1993, 181 million tons of this coal was delivered to electric utilities in the region (Table 38). This represented 43 percent of the total, down from 48 percent in 1979. Shipments to utilities in the South grew rapidly between 1979 and 1986, and by 1993 they represented 32 percent of the total. For the 1979 through 1993 period, shipments to utilities in the West grew most rapidly, reaching 18 percent of the total (up from 14 percent in 1979). The Northeast's share of the national total declined from 9 percent to 8 percent over the same period.

\section{Transportation Modes}

Railroads were the predominant contract coal transporters in all regions in all 3 years, with two exceptions.
Conveyors were the primary mode for moving coal from the mine to the power plant in the West in 1993, and trucks hauled slightly more coal than railroads to electric utilities in the West in 1986 (Table 38). In the West, less than one-third of the coal was moved by rail in 1993. At the other extreme, 71 percent of the coal delivered to utilities in the South was transported by rail.

In the Northeast, nearly half of the contract coal transported to electric utilities was moved by rail in 1993, up from 35 percent in 1979. Multimodal shipments also increased, to 9 percent of the total. The percentage moved by truck fell from 17 percent in 1979 to 10 percent in 1993. Barge's share fell from 29 percent in 1979 to 21 percent in 1986, and then recovered to 25 percent in 1993. This share was higher than in any other region, although the absolute tonnage of coal shipped by barge was greatest in the South. The shift toward rail and multimodal transportation in the Northeast may have been partly due to the significant decline in rail rates over the period.

Railroads hauled 61 percent of the contract coal received by utilities in the Midwest in 1993, virtually the same share as in 1979. Multimodal (primarily rail/ barge) movements accounted for 14 percent of the total in 1993, down from 16 percent in 1978. Over the same period, barges and trucks each gained about 2 percent in market share. Railroads lost some market share between 1979 and 1986, when increasing amounts of coal were delivered by relatively short truck and barge movements from Appalachia, but regained market share between 1986 and 1993, when long-distance shipments from the West increased.

Railroad coal transportation was more important for utilities in the South than in any other region, as 71 percent of their 1993 contract coal deliveries were by rail. Railroads lost part of their market share between 1979 and 1986, but more than regained it by 1993. Barges also gained market share, delivering 17 million tons of contract coal to utilities in the South in 1993. This represented 13 percent of total contract coal shipments to the region and 38 percent of U.S. barge movements of contract coal. Meanwhile, truck and multimodal movements declined. 
Figure 9. Demand Regions

West

Midwest
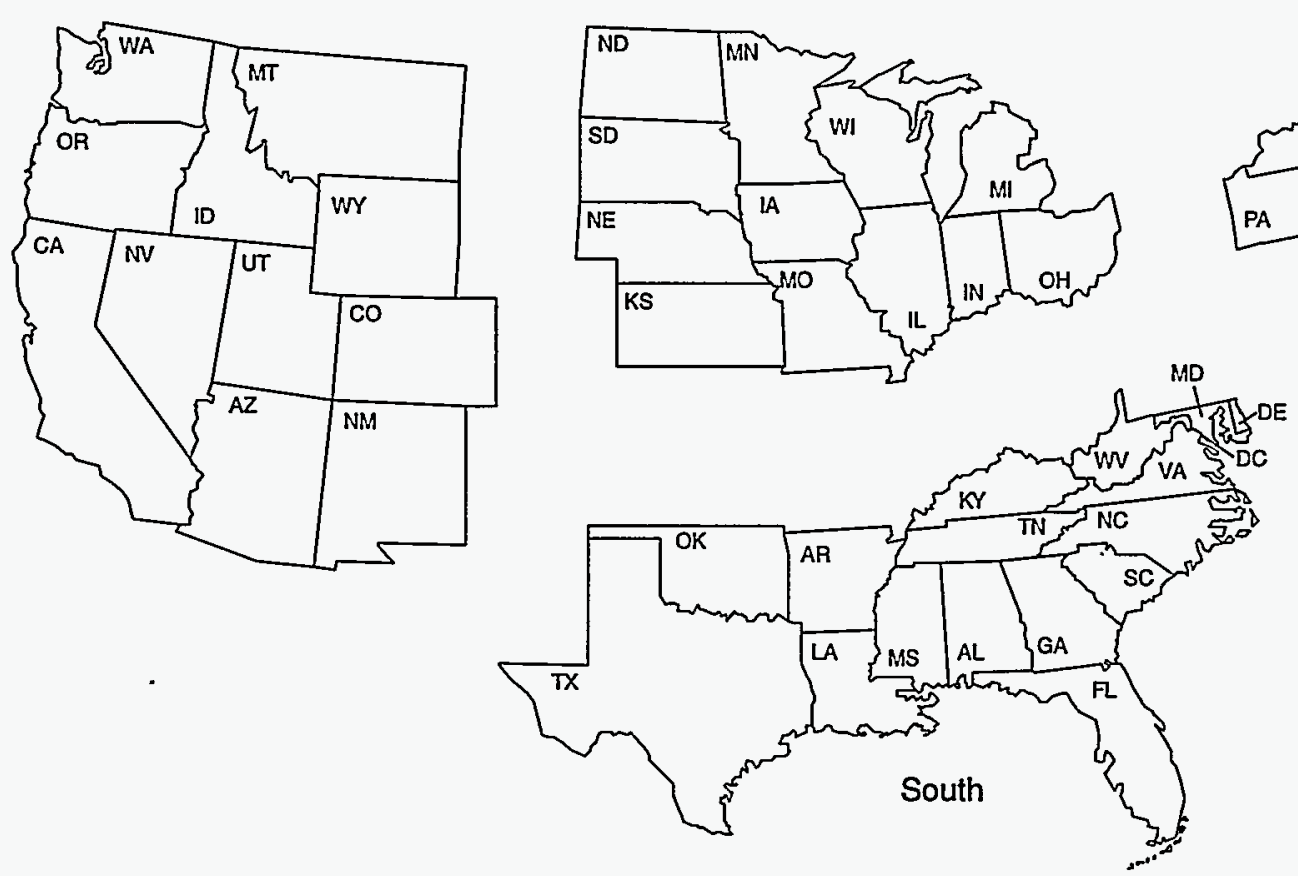

Northeast

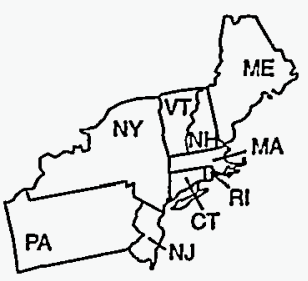

\section{Demand Regions}

$\begin{array}{ll}\text { Northeast } & \text { Midwest } \\ \text { Connecticut } & \text { Illinois } \\ \text { Maine } & \text { Indiana } \\ \text { Massachusetts } & \text { lowa } \\ \text { New Hampshire } & \text { Kansas } \\ \text { New Jersey } & \text { Michigan } \\ \text { New York } & \text { Minnesota } \\ \text { Pennsylvania } & \text { Missouri } \\ \text { Rhode Island } & \text { Nebraska } \\ \text { Vermont } & \text { North Dakota } \\ & \text { Ohio } \\ & \text { South Dakota } \\ & \text { Wisconsin }\end{array}$

South

Alabama

Arkansas

Delaware

District of Columbia

Florida

Georgia

Kentucky

Louisiana

Maryland

Mississippi

North Carolina

Oklahoma

South Carolina

Tennessee

Texas

Virginia

West Virginia
West

Arizona

California

Colorado

Idaho

Montana

Nevada

New Mexico

Oregon

Utah

Washington

Wyoming 
Table 38. Utility Contract Coal Tonnage by Demand Region and Transportation Mode, 1979, 1986, and 1993

\begin{tabular}{|c|c|c|c|c|c|c|}
\hline \multirow[b]{2}{*}{$\begin{array}{l}\text { Demand Region/ } \\
\text { Mode of Transportation }\end{array}$} & \multicolumn{2}{|c|}{1979} & \multicolumn{2}{|c|}{1986} & \multicolumn{2}{|c|}{1993} \\
\hline & $\begin{array}{l}\text { Tonnage } \\
\text { (million } \\
\text { short tons) }\end{array}$ & $\begin{array}{l}\text { Percent } \\
\text { of Total }\end{array}$ & $\begin{array}{l}\text { Tonnage } \\
\text { (million } \\
\text { short tons) }\end{array}$ & $\begin{array}{l}\text { Percent } \\
\text { of Total }\end{array}$ & $\begin{array}{l}\text { Tonnage } \\
\text { (million } \\
\text { short tons) }\end{array}$ & $\begin{array}{l}\text { Percent } \\
\text { of Total }\end{array}$ \\
\hline \multicolumn{7}{|l|}{ Northeast } \\
\hline Rail............... & 10.6 & 35.1 & 8.8 & 37.1 & 15.5 & 48.9 \\
\hline Barge $\ldots \ldots \ldots \ldots \ldots$ & 8.8 & 29.4 & 4.9 & 20.8 & 8.0 & 25.1 \\
\hline Truck .............. & 5.1 & 17.1 & 3.9 & 16.6 & 3.2 & 10.0 \\
\hline Multimode $^{a} \ldots \ldots \ldots \ldots$ & 1.6 & 5.4 & 2.5 & 10.3 & 2.7 & 8.6 \\
\hline Other $\ldots \ldots \ldots \ldots \ldots$ & 3.9 & 13.0 & 3.6 & 15.2 & 2.3 & 7.4 \\
\hline Region Total $\ldots \ldots \ldots$ & 30.1 & 100.0 & 23.7 & 100.0 & 31.7 & 100.0 \\
\hline \multicolumn{7}{|l|}{ Midwest } \\
\hline Rail ................ & 102.2 & 60.3 & 102.2 & 58.6 & 110.9 & 61.4 \\
\hline Barge $\ldots \ldots \ldots \ldots \ldots$ & 15.1 & 8.9 & 17.8 & 10.2 & 19.9 & 11.0 \\
\hline Truck $\ldots \ldots \ldots \ldots \ldots$ & 9.9 & 5.8 & 11.3 & 6.5 & 12.6 & 6.9 \\
\hline Multimode $^{\mathrm{a}} \ldots \ldots \ldots \ldots$ & 26.2 & 15.5 & 28.5 & 16.3 & 25.0 & 13.8 \\
\hline Other $\ldots \ldots \ldots \ldots \ldots$ & 16.0 & 9.5 & 14.6 & 8.4 & 12.4 & 6.8 \\
\hline Region Total $\ldots \ldots \ldots$ & 169.4 & 100.0 & 174.4 & 100.0 & 180.8 & 100.0 \\
\hline \multicolumn{7}{|l|}{ South } \\
\hline 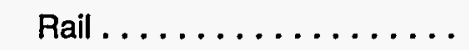 & 70.8 & 68.4 & 98.1 & 59.9 & 93.7 & 70.8 \\
\hline Barge $\ldots \ldots \ldots \ldots \ldots$ & 10.1 & 9.8 & 7.0 & 4.3 & 16.9 & 12.8 \\
\hline Truck .............. & 5.5 & 5.3 & 10.3 & 6.3 & 3.2 & 2.4 \\
\hline Multimode $^{\mathrm{a}} \ldots \ldots \ldots \ldots$ & 8.2 & 7.9 & 13.5 & 8.2 & 7.8 & 5.9 \\
\hline Other $\ldots \ldots \ldots \ldots \ldots$ & 8.9 & 8.6 & 35.0 & 21.4 & 10.7 & 8.1 \\
\hline Region Total $\ldots \ldots \ldots$ & 103.6 & 100.0 & 163.9 & 100.0 & 132.4 & 100.0 \\
\hline \multicolumn{7}{|l|}{ West } \\
\hline 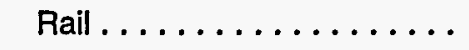 & 23.1 & 45.7 & 21.5 & 35.3 & 22.3 & 30.5 \\
\hline Barge $\ldots \ldots \ldots \ldots \ldots$ & -- & -- & -- & - & -- & -- \\
\hline Truck $\ldots \ldots \ldots \ldots \ldots$ & 5.7 & 11.3 & 22.5 & 36.9 & 17.3 & 23.7 \\
\hline Multimode $^{\mathrm{a}} \ldots \ldots \ldots \ldots$ & -- & -- & -- & - & - & - \\
\hline Other $^{b} \ldots \ldots \ldots \ldots \ldots$ & 21.8 & 43.1 & 16.9 & 27.8 & 33.5 & 45.8 \\
\hline Region Total $\ldots \ldots \ldots$ & 50.6 & 100.0 & 60.9 & 100.0 & 73.2 & 100.0 \\
\hline \multicolumn{7}{|l|}{ United States } \\
\hline Rail $\ldots \ldots \ldots \ldots \ldots \ldots$ & 206.7 & 58.4 & 230.6 & 54.5 & 242.5 & 58.0 \\
\hline Barge $\ldots \ldots \ldots \ldots \ldots$ & 34.0 & 9.6 & 29.8 & 7.0 & 44.8 & 10.7 \\
\hline Truck $\ldots \ldots \ldots \ldots \ldots$ & 26.2 & 7.4 & 48.0 & 11.4 & 36.2 & 8.7 \\
\hline Multimode $^{\mathrm{a}} \ldots \ldots \ldots \ldots$ & 36.0 & 10.2 & 44.4 & 10.5 & 35.6 & 8.5 \\
\hline Otherb $\ldots \ldots \ldots \ldots \ldots$ & 50.7 & 14.3 & 70.2 & 16.6 & 58.9 & 14.1 \\
\hline Region Total $\ldots \ldots \ldots$ & 353.7 & 100.0 & 423.0 & 100.0 & 418.0 & 100.0 \\
\hline
\end{tabular}

Includes shipments that use any combination of rail, barge, and collier transportation.

bIncludes conveyor, tramway, slurry pipeline, and shipments for which mode is unknown.

-- = Not applicable.

Source: Energy Information Administration, Coal Transportation Rate Data Base. 
For the contract coal delivered to electric utilities in the West, the transportation market is more evenly shared among the various transportation modes (excluding barge, which is unavailable in the West) than in any other region. Western power plants are often located at mine sites and the coal is moved to the plant by conveyor. In 1993, conveyors and the Black Mesa coal slurry pipeline (both included in the "other" mode category) accounted for 46 percent of the coal shipments to utilities in the West. In the same year, trains and trucks accounted for about 31 percent and 24 percent of the total, respectively. Between 1979 and 1993, rail's share fell by one-third, while trucks' share more than doubled.

\section{Contract Duration}

The average duration of electric utility coal supply contracts differs widely among the demand regions. It also changes substantially from year to year, as utilities, within the bounds of contract provisions, take less coal under their contracts when spot prices are lower, and shift their contract purchases to contracts with relatively low prices.

The distribution of contract coal deliveries across different contract duration categories is more stable for utilities in the Northeast than in any other demand region. In 1993, 50 percent of the region's deliveries were under short-term contract, 39 percent were under medium-term contract, and 11 percent were under long-term contract (Table 39). The most significant change in that region occurred between 1986 and 1993, when utilities shifted purchases from long-term contracts (which had relatively high average prices at a time when coal prices were falling) to medium-term contracts.

Table 39. Distribution of Utility Contract Coal Tonnage by Contract Duration and Demand Region, 1979,1986 , and 1993

\begin{tabular}{|c|c|c|c|c|c|c|c|}
\hline \multirow[b]{3}{*}{$\begin{array}{c}\text { Year/ } \\
\text { Demand Region }\end{array}$} & \multicolumn{6}{|c|}{ Contract Duration } & \multirow{3}{*}{$\begin{array}{c}\begin{array}{c}\text { All } \\
\text { Contracts }\end{array} \\
\begin{array}{c}\text { Tonnage } \\
\text { (million } \\
\text { short tons) }\end{array}\end{array}$} \\
\hline & \multicolumn{2}{|c|}{$\begin{array}{c}\text { Short-Term } \\
\text { (10 Years of Less) }\end{array}$} & \multicolumn{2}{|c|}{$\begin{array}{l}\text { Medium-Term } \\
\text { (11-30 Years) }\end{array}$} & \multicolumn{2}{|c|}{$\begin{array}{c}\text { Long-Term } \\
\text { (More Than } 30 \text { Years) }\end{array}$} & \\
\hline & $\begin{array}{l}\text { Tonnage } \\
\text { (million } \\
\text { short tons) }\end{array}$ & $\begin{array}{l}\text { Percent } \\
\text { of Total }\end{array}$ & $\begin{array}{l}\text { Tonnage } \\
\text { (million } \\
\text { short tons) }\end{array}$ & $\begin{array}{l}\text { Percent } \\
\text { of Total }\end{array}$ & $\begin{array}{l}\text { Tonnage } \\
\text { (million } \\
\text { short tons) }\end{array}$ & $\begin{array}{l}\text { Percent } \\
\text { of Total }\end{array}$ & \\
\hline \multicolumn{8}{|l|}{1979} \\
\hline Northeast & 14.6 & 48.4 & 10.5 & 35.0 & 5.0 & 16.6 & 30.1 \\
\hline Midwest $\ldots . .$. & 25.6 & 15.1 & 117.7 & 69.5 & 26.1 & 15.4 & 169.4 \\
\hline South ........ & 28.9 & 27.9 & 58.2 & 56.2 & 16.6 & 16.0 & 103.6 \\
\hline West ......... & 7.3 & 14.4 & 2.9 & 5.8 & 40.4 & 79.8 & 50.6 \\
\hline United States .. & 76.3 & 21.6 & 189.3 & 53.5 & 88.0 & 24.9 & 353.7 \\
\hline \multicolumn{8}{|l|}{1986} \\
\hline Northeast .... & 12.6 & 53.0 & 7.4 & 31.3 & 3.7 & 15.6 & 23.7 \\
\hline Midwest $\ldots . \ldots$ & 31.6 & 18.1 & 104.6 & 60.0 & 38.2 & 21.9 & 174.4 \\
\hline South ........ & 67.3 & 41.1 & 67.4 & 41.1 & 29.2 & 17.8 & 163.9 \\
\hline West .......... & 0.2 & 0.3 & 7.3 & 12.1 & 53.4 & 87.6 & 60.9 \\
\hline United States .. & 111.7 & 26.4 & 186.8 & 44.2 & 124.5 & 29.4 & 423.0 \\
\hline \multicolumn{8}{|l|}{1993} \\
\hline Northeast .... & 15.9 & 50.1 & 12.2 & 38.6 & 3.6 & 11.3 & 31.7 \\
\hline Midwest & 68.1 & 37.7 & 68.9 & 38.1 & 43.8 & 24.2 & 180.8 \\
\hline South ....... & 41.2 & 31.1 & 62.6 & 47.3 & 28.6 & 21.6 & 132.4 \\
\hline West ......... & 14.9 & 20.3 & 16.5 & 22.5 & 41.8 & 57.2 & 73.2 \\
\hline United States . . & 140.1 & 33.5 & 160.1 & 38.3 & 117.9 & 28.2 & 418.0 \\
\hline
\end{tabular}

Source: Energy Information Administration, Coal Transportation Rate Data Base. 
In the Midwest, there was a dramatic shift between 1986 and 1993, from medium-term contracts to shortterm contracts. As a result, the proportion of coal shipped under medium-term contracts in the Midwest more closely resembled that share in other regions, rather than being unusually high, as in 1979 and 1986.

In the South, there were substantial swings in the coal tonnage delivered under short-term and medium-term contracts. Purchases shifted from medium-term contracts to short-term contracts between 1979 and 1986, and then shifted back between 1986 and 1993.

The proportion of coal delivered under long-term contract was much higher in the West than in the other demand regions. The preference for long-term contracts reflects the practice of siting large power plants near mines in the West, a situation that, in turn, results from the high cost per million Btu of transporting low-Btu Western coal. Once the plant is built, coal supply options are extremely limited. If the utility does not secure coal supplies through a long-term contract, it may own the coal supplies, i.e., the mine is "captive" to the utility.

Nevertheless, utilities in the West reduced their reliance on long-term contracts significantly between 1986 and 1993. During that time, the proportion of coal shipments that were delivered under long-term contract fell from 88 percent to 57 percent. This was probably due to the development of excess coal production capacity at Western mines and the substantial decline in rail transportation rates, which gave utilities more flexibility in obtaining coal supplies.

In 1993, the average contract duration (weighted by the annual coal tonnage shipped under the contract) ranged from 11 years for shipments to utilities in the Northeast to 29 years for shipments to utilities in the West (Table 40). Between 1979 and 1993, the average contract duration declined in all demand regions except the South. The change was greatest in the Northeast, where the average duration fell by 28 percent.

\section{Average Distance Shipped}

Generally, the transportation mode is a good indicator of shipping distance. The shortest movements are for conveyors, followed by trucks, barges, and trains. The longest shipments are multimodal, usually combining rail and barge transportation. In 1993, the average distance for the coal shipped under electric utility
Table 40. Average Utility Contract Duration by Demand Region and Transportation Mode, 1979, 1986, and 1993 (Years)

\begin{tabular}{|c|c|c|c|}
\hline $\begin{array}{l}\text { Demand } \\
\text { Region/Mode of } \\
\text { Transportation }\end{array}$ & 1979 & 1986 & 1993 \\
\hline \multicolumn{4}{|l|}{ Northeast } \\
\hline Rail ... & 13.5 & 8.2 & 7.8 \\
\hline Barge $\ldots \ldots \ldots$ & 19.2 & 17.8 & 19.9 \\
\hline Truck ......... & 5.0 & 5.7 & 11.8 \\
\hline Multimode $^{\mathrm{a}} \ldots \ldots$ & 6.0 & 5.1 & 4.1 \\
\hline Other $^{b} \ldots \ldots \ldots$ & 32.3 & 32.2 & 13.0 \\
\hline Region Average . & 15.8 & 13.1 & 11.3 \\
\hline \multicolumn{4}{|l|}{ Midwest } \\
\hline Rail ... & 20.2 & 22.6 & 17.1 \\
\hline Barge $\ldots .$. & 19.5 & 16.2 & 15.5 \\
\hline Truck ......... & 24.9 & 20.8 & 19.5 \\
\hline Multimode $^{\mathrm{a}} \ldots \ldots$ & 17.5 & 25.9 & 23.3 \\
\hline Other ${ }^{b} \ldots$. & 31.0 & 28.9 & 28.1 \\
\hline Region Average . & 21.0 & 22.9 & 18.7 \\
\hline \multicolumn{4}{|l|}{ South } \\
\hline Rail. & 17.6 & 19.6 & 20.8 \\
\hline Barge $\ldots \ldots \ldots$ & 25.5 & 19.2 & 16.1 \\
\hline Truck ......... & 8.3 & 18.6 & 8.6 \\
\hline Multimode $^{\mathrm{a}} \ldots \ldots$ & 13.8 & 14.5 & 12.0 \\
\hline Other $^{b} \ldots \ldots \ldots$ & 22.3 & 5.7 & 21.2 \\
\hline Region Average . & 18.0 & 16.1 & 19.4 \\
\hline \multicolumn{4}{|l|}{ West } \\
\hline Rail........... & 31.8 & 34.0 & 18.7 \\
\hline Barge $\ldots \ldots \ldots$ & -- & -- & -- \\
\hline Truck $\ldots \ldots \ldots$. & 33.4 & 36.1 & 28.1 \\
\hline Multimode $^{\mathrm{a}} \ldots \ldots$ & -- & -. & -- \\
\hline Other $^{b} \ldots \ldots \ldots$ & 34.5 & 38.9 & 35.4 \\
\hline Region Average . & 33.2 & 36.2 & 28.6 \\
\hline \multicolumn{4}{|l|}{ United States } \\
\hline Rail . . . . . . . . & 20.3 & 21.8 & 18.1 \\
\hline Barge $\ldots \ldots \ldots$. & 21.2 & 17.1 & 16.5 \\
\hline Truck .......... & 19.4 & 26.3 & 22.0 \\
\hline Multimode $^{\mathrm{a}} \ldots \ldots$ & 16.1 & 21.3 & 19.4 \\
\hline Other $\ldots . . . \ldots$ & 31.1 & 19.9 & 30.4 \\
\hline U.S. Average ... & 21.4 & 21.6 & 20.1 \\
\hline
\end{tabular}

ancludes shipments that use any combination of rail, barge, and collier transportation.

bIncludes conveyor, tramway, slurry pipeline, and shipments for which mode is unknown.

$--=$ Not applicable.

Source: Energy Information Administration, Coal Transportation Rate Data Base. 
contracts ranged from 8 miles for conveyor ${ }^{44}$ movements in the South to 1,249 miles for multimodal shipments to utilities in the Midwest (Table 41). The average distance for all modes combined was about 675 miles for shipments to utilities in the Midwest, 660 miles for shipments to the South, 278 miles for shipments to utilities in the Northeast, and 169 miles for shipments to power plants in the West, where short haul conveyor and truck movements predominate.

Between 1979 and 1993, the average shipping distance increased in all demand regions. The percentage increase was greatest in the South, where average distance rose by 40 percent, largely due to a shift toward low-sulfur Western coal supplies. It was smallest (12 percent) in the West, where coal is obtained from mines within the region. Average shipping distance increased by about one-third in both the Northeast and the Midwest.

In the Northeast, the average distance for multimodal movements rose by 47 percent between 1979 and 1993, while the average distance for barge movements fell by 8 percent. Average trucking distance declined between 1979 and 1993, and then increased by 86 percent from 1986 to 1993.

For the contract coal shipped to utilities in the Midwest, the average distance of rail hauls increased by 36 percent between 1979 and 1993, and the average distance of multimodal movements rose by 43 percent. These changes reflected the increase in shipments of low-sulfur Western coal to utilities in the Midwest. Average distances for shorter-haul barge and truck movements were about the same in 1993 as in 1979.

For shipments to utilities in the West, the average length of rail hauls increased by 61 percent between 1979 and 1993, while the average distance of truck movements fell by 59 percent, with most of these changes occurring between 1979 and 1986. There was little change for each of these modes between 1986 and 1993, but the average distance for all modes combined rose by 44 percent because of the decline in the percentage of coal that was shipped short distances by truck.

\section{Transportation Rate per Ton}

Coal transportation cost depends largely on three factors: the amount of coal shipped, the distance the coal is shipped, and the transportation mode used (which itself is often determined by the first two
Table 41. Average Distance Shipped per Ton for Utility Contract Coal by Demand Region and Transportation Mode, 1979, 1986, and 1993 (Miles)

\begin{tabular}{|c|c|c|c|}
\hline $\begin{array}{l}\text { Demand } \\
\text { Region/Mode of } \\
\text { Transportation }\end{array}$ & 1979 & 1986 & 1993 \\
\hline \multicolumn{4}{|l|}{ Northeast } \\
\hline Rail $\ldots \ldots \ldots \ldots$ & 330.1 & 360.2 & 345.6 \\
\hline Barge $\ldots \ldots \ldots$ & 69.8 & 78.9 & 64.4 \\
\hline Truck & 70.4 & 45.1 & 84.0 \\
\hline Multimode $^{\text {a }} \ldots \ldots$ & 521.9 & 723.1 & 766.1 \\
\hline Other $^{b} \ldots \ldots \ldots$ & -- & -- & -- \\
\hline Region Average . & 213.2 & 294.7 & 278.2 \\
\hline \multicolumn{4}{|l|}{ Midwest } \\
\hline Rail .. & 533.9 & 492.0 & 726.1 \\
\hline$\ldots \ldots$ & 240.3 & 205.9 & 241.6 \\
\hline Truck & 35.7 & 27.8 & 34.9 \\
\hline Multimode $^{\mathrm{a}}$ & 875.7 & 758.2 & 1249.0 \\
\hline Other ${ }^{b}$. & 7.8 & 5.8 & 10.0 \\
\hline Region Average . & 507.6 & 444.0 & 675.2 \\
\hline \multicolumn{4}{|l|}{ South } \\
\hline Rail ...... & 490.2 & 609.4 & 725.2 \\
\hline Barge ... & 695.4 & 949.8 & 540.1 \\
\hline Truck ... & 2.9 & 10.0 & 34.0 \\
\hline Multimode $\mathrm{a}^{\mathrm{a}}$ & 355.6 & 497.1 & 497.6 \\
\hline Other $\ldots$ & 9.6 & 8.5 & 7.5 \\
\hline Region Average & 472.1 & 569.6 & 659.7 \\
\hline \multicolumn{4}{|l|}{ West } \\
\hline Rail . & 204.0 & 315.4 & 328.6 \\
\hline Barge $\ldots \ldots \ldots$ & -- & -. & -- \\
\hline Truck $\ldots \ldots \ldots$ & 31.9 & 13.1 & 13.1 \\
\hline Multimode $^{\mathrm{a}} \ldots$ & -- & -- & -- \\
\hline Other ${ }^{b} \ldots$. & 88.4 & 98.1 & 86.6 \\
\hline Region Average & 151.0 & 117.7 & 169.4 \\
\hline \multicolumn{4}{|l|}{ United States } \\
\hline Rail ..... . & 479.2 & 530.6 & 671.3 \\
\hline Barge $\ldots \ldots$ & 313.5 & 359.2 & 292.8 \\
\hline Truck .. & 38.2 & 18.8 & 32.0 \\
\hline Multimode $^{\mathrm{a}}$ & 751.2 & 658.0 & 1053.5 \\
\hline Other $\ldots$ & 47.5 & 63.9 & 63.2 \\
\hline U.S. Average $\ldots$ & 437.7 & 441.1 & 576.1 \\
\hline
\end{tabular}

ancludes shipments that use any combination of rail, barge, and collier transportation.

blncludes conveyor, tramway, slurry pipeline, and shipments for which mode is unknown.

-- = Not applicable.

Source: Energy Information Administration, Coal Transportation Rate Data Base.

\footnotetext{
${ }^{44}$ Conveyor movements are included in the "other" mode category.
} 
factors). In 1993, the average transportation cost for contract coal delivered to electric utilities ranged from $\$ 4.67$ per ton in the West to $\$ 9.50$ per ton in the South (Table 42, Figure 10). Transportation from mines to power plants in the West is characterized by short-haul conveyor and truck movements. Transportation to utilities in the South is dominated by long-distance rail hauls from Appalachian and, increasingly, Western mines.

When individual transportation modes are distinguished, differences in transportation cost are even wider, ranging from $\$ 1.61$ per ton for barge shipments to utilities in the Midwest to $\$ 13.27$ per ton for multimodal shipments in the Northeast. Barge transportation is inherently less costly than train or multimodal transportation, and barge movements to utilities in the Midwest are relatively short. On the other hand, the average shipping distance for multimodal movements is much longer than for other transportation modes.

Between 1979 and 1993, the average contract coal transportation cost per ton fell in all demand regions except the West, where it rose by 1 percent, due to a shift from short truck movements to longer rail movements. Transportation cost fell for most modes, with the exception of barge shipments to utilities in the Northeast, barge and multimodal shipments to utilities in the South, and rail shipments to utilities in the West. The cost increases in these regions for rail and multimodal movements were due to increases in average shipping distance. For contract coal shipments to the South, the average transportation cost rose as shipping distance increased between 1979 and 1986. The average rate per ton came back down between 1986 and 1993, as rail and barge rates fell.

Primarily, because of the regional differences in shipping distance, the transportation component of delivered coal prices varies from region to region. For electric utilities in the Northeast, where the average shipping distance for coal receipts is relatively short, transportation cost represented about one-quarter of the average delivered price (Table 43). For utilities in the Midwest, where many utilities receive coal from distant mines, transportation cost represented nearly one-third of the average delivered price.

Between 1979 and 1993, the transportation component of delivered coal prices increased in all four demand regions, reflecting the increases in the distance the coal was shipped. The increase was by far the greatest for utilities in the South, where transportation cost as a proportion of average delivered price rose from 20
Table 42. Average Utility Contract Coal Transportation Rate per Ton by Demand Region and Transportation Mode, 1979, 1986, and 1993 (1987 Dollars per Short Ton)

\begin{tabular}{|c|c|c|c|}
\hline $\begin{array}{l}\text { Demand } \\
\text { Region/Mode of } \\
\text { Transportation }\end{array}$ & 1979 & 1986 & 1993 \\
\hline \multicolumn{4}{|l|}{ Northeast } \\
\hline Rail ........... & 11.64 & 11.27 & 9.15 \\
\hline Barge $\ldots \ldots \ldots \ldots$ & 1.73 & 1.58 & 2.32 \\
\hline Truck ......... & 9.01 & 5.30 & 6.65 \\
\hline Multimode $^{\mathrm{a}} \ldots \ldots$ & 20.79 & 18.64 & 13.27 \\
\hline Other $\ldots$ & - & -- & - \\
\hline Region Average . & 9.40 & 8.40 & 8.18 \\
\hline \multicolumn{4}{|l|}{ Midwest } \\
\hline Rail ........... & 11.54 & $7.81^{\prime}$ & 8.29 \\
\hline Barge ......... & 2.71 & 2.46 & 1.61 \\
\hline Truck .......... & 6.76 & 2.79 & 3.38 \\
\hline Multimode $^{\mathrm{a}}$ & 18.14 & 16.10 & 10.94 \\
\hline Other $r^{b} .$. & 1.00 & 0.01 & .90 \\
\hline Region Average . & 11.25 & 8.08 & 7.41 \\
\hline \multicolumn{4}{|l|}{ South } \\
\hline Rail ........... & 11.16 & 14.42 & 10.43 \\
\hline Barge $\ldots \ldots \ldots$. & 3.42 & 5.35 & 4.61 \\
\hline Truck ......... & 6.28 & 4.34 & 2.41 \\
\hline Multimode $^{\mathrm{a}}$ & 8.24 & 6.71 & 8.75 \\
\hline Other ${ }^{b} . .$. & 3.95 & -- & -- \\
\hline Region Average . & 9.90 & 12.76 & 9.50 \\
\hline \multicolumn{4}{|l|}{ West } \\
\hline Rail .......... & 4.59 & 7.51 & 5.91 \\
\hline Truck ......... & 5.45 & 5.07 & 3.71 \\
\hline Other $^{b} \ldots \ldots \ldots$ & 4.44 & 3.42 & 2.52 \\
\hline Region Average . & 4.63 & 5.05 & 4.67 \\
\hline \multicolumn{4}{|l|}{ United States } \\
\hline Rail...... & 10.80 & 11.00 & 8.93 \\
\hline Barge $\ldots \ldots \ldots$ & 2.73 & 2.88 & 2.81 \\
\hline Truck ......... & 6.85 & 4.31 & 3.56 \\
\hline Multimode $^{\mathrm{a}}$ & 16.00 & 13.61 & 10.66 \\
\hline Other ${ }^{b} \ldots$ & 2.63 & 2.74 & 1.88 \\
\hline U.S. Average . . & 10.11 & 9.45 & 7.83 \\
\hline
\end{tabular}

Includes shipments that use any combination of rail, barge, and collier transportation.

' Includes conveyor, tramway, slurry pipeline, and shipments for which mode is unknown.

-- = Not applicable.

Source: Energy Information Administration, Coal Transportation Rate Data Base. 
Figure 10. Average Utility Contract Coal Transportation Rate per Ton by Demand Region, 1979, 1986, and 1993

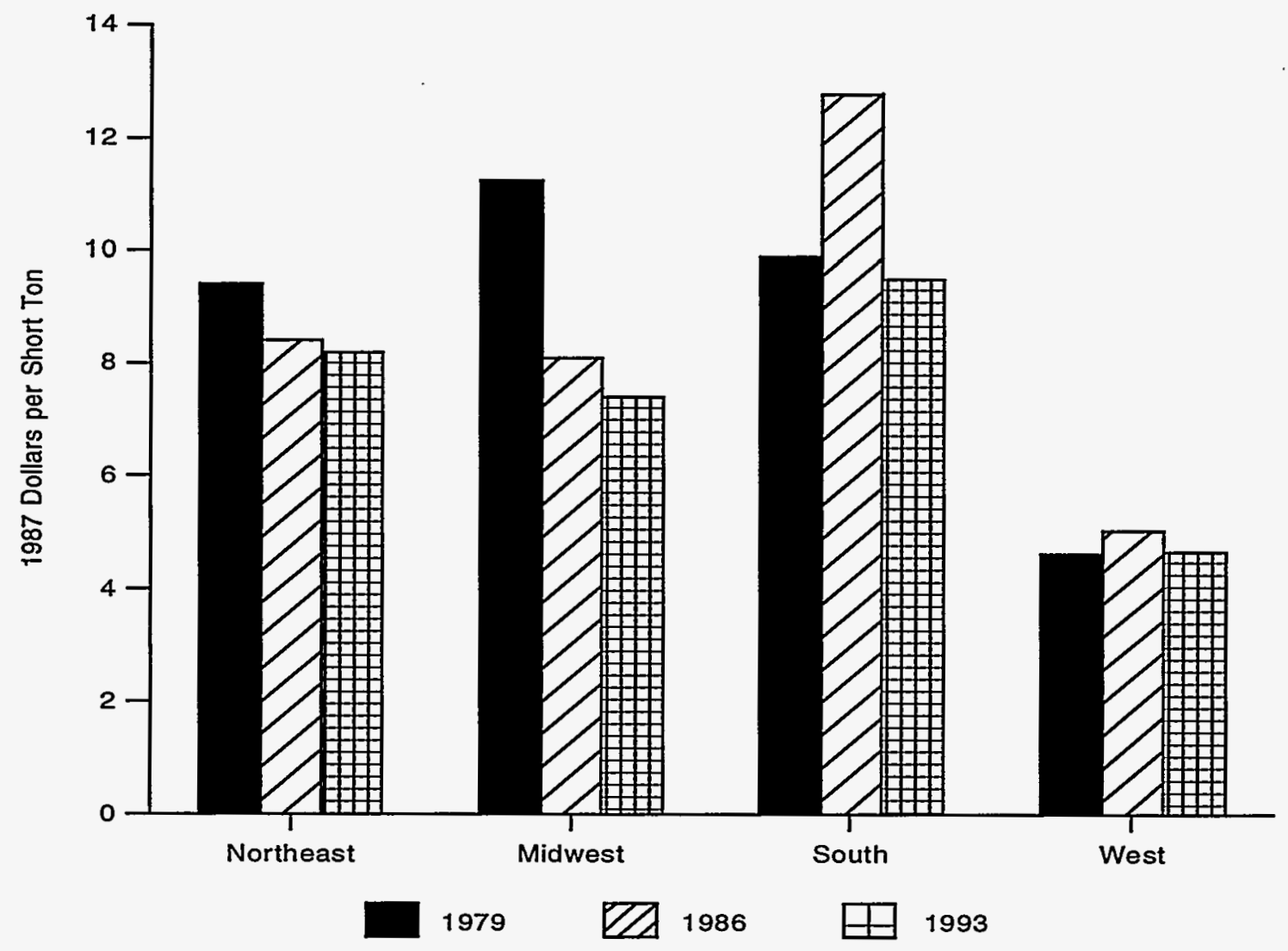

Source: Energy Information Administration, Coal Transportation Rate Data Base.

Table 43. Utility Contract Coal Transportation Cost as a Percentage of Delivered Price by Demand Region, 1979-1993

(Percent)

\begin{tabular}{l|c|c|c|c|c|c|c|c|c|c|c|c|c|c|c}
\hline Demand Region & 1979 & 1980 & 1981 & 1982 & 1983 & 1984 & 1985 & 1986 & 1987 & 1988 & 1989 & 1990 & 1991 & 1992 & 1993 \\
\hline Northeast ...... & 19.5 & 19.8 & 22.5 & 19.1 & 24.8 & 30.3 & 25.7 & 19.0 & 19.3 & 25.9 & 25.9 & 26.0 & 24.5 & 24.1 & 25.6 \\
Midwest ....... & 28.1 & 28.3 & 31.1 & 29.0 & 30.4 & 30.4 & 26.4 & 21.8 & 21.5 & 32.3 & 33.6 & 29.2 & 29.4 & 30.0 & 32.9 \\
South ........ & 19.9 & 20.7 & 22.3 & 22.3 & 22.9 & 28.6 & 26.6 & 30.8 & 30.7 & 28.8 & 27.7 & 29.3 & 28.5 & 29.5 & 30.6 \\
West ......... & 24.0 & 25.2 & 26.7 & 23.2 & 22.1 & 22.6 & 27.1 & 21.1 & 21.3 & 32.3 & 32.3 & 24.6 & 23.7 & 25.9 & 26.6 \\
United States .. & 24.9 & 25.2 & 27.3 & 25.6 & 27.2 & 29.0 & 26.6 & 25.3 & 25.0 & 30.7 & 30.7 & 28.9 & 28.3 & 29.4 & 31.2 \\
\hline
\end{tabular}

Source: Energy Information Administration, Coal Transportation Rate Data Base. 
percent in 1979 to 31 percent in 1993. This 55-percent increase was primarily due to a 40 -percent increase in average shipping distance over the same period.

\section{Transportation Rate per Ton-Mile}

Since the average shipping distance for contract coal increased between 1979 and 1993, the decline in the average transportation rate per ton was possible only because of a substantial reduction in the average cost of shipping the coal each mile. Between 1979 and 1993, the average rate per ton-mile (for all modes combined) fell for deliveries to electric utilities in all demand regions (Table 44, Figure 11). The decline was greatest in the Midwest (a 48-percent fall), followed by the South (38 percent), and the Northeast (36 percent). In the West, the average rate per ton-mile fell by only 8 percent. The decline was smaller partly because of an increase in high-cost truck shipments. Average rates fell for all modes in all regions, except for barge movements to utilities in the Northeast and truck hauls to utilities in the West.

In 1993, the average contract coal transportation rate per ton-mile ranged from 7 mills ( 0.7 cent) for barge shipments to electric utilities in the Midwest to 198 mills (20 cents) for truck hauls to power plants in the West. For all transportation modes combined, the average rate per ton-mile was lowest in the Midwest, which had lower rail, barge, truck, and multimodal rates than any other demand region. In the Northeast and the West, the average rate per ton-mile for all modes combined was more than twice the average for the Midwest.

Barge rates were relatively high in the Northeast, where they rose substantially between 1986 and 1993, while truck rates were relatively high in the West. ${ }^{45}$ For rail transportation, the average rate per ton-mile was highest in the Northeast and the West, where the average shipping distances were relatively short. The average rate per ton-mile was substantially lower in the Midwest and the South, where rail hauls were relatively long.

In fact, the average shipping distance appears to be the primary reason for the interregional difference in the average rate per ton-mile. Generally, the longer the shipping distance, the lower is the rate per ton-mile. Primarily, this is because, as shipping distance increases, fixed costs (i.e., costs that do not vary with distance) are spread over more ton-miles. Other factors that may
Table 44. Average Utility Contract Coal Transportation Rate Per Ton-Mile by Demand Region and Transportation Mode, 1979, 1986, and 1993 (Mills in 1987 Dollars)

\begin{tabular}{|c|c|c|c|}
\hline Demand Region & 1979 & 1986 & 1993 \\
\hline \multicolumn{4}{|l|}{ Northeast } \\
\hline Rail ............. & 34.0 & 35.9 & 25.2 \\
\hline Barge $\ldots \ldots \ldots \ldots$ & 31.7 & 20.0 & 42.1 \\
\hline Truck $\ldots \ldots \ldots \ldots$ & 80.3 & 92.3 & 19.0 \\
\hline Multimode $^{\mathrm{a}} \ldots \ldots \ldots$ & 38.9 & 30.1 & 17.3 \\
\hline Other $^{b} \ldots \ldots \ldots \ldots$ & $\ldots$ & - & - \\
\hline Region Average . . . . & 36.8 & 34.2 & 23.4 \\
\hline \multicolumn{4}{|l|}{ Midwest } \\
\hline Rail ... & 21.0 & 25.2 & 11.3 \\
\hline Barge $\ldots \ldots \ldots \ldots$ & 10.6 & 10.4 & 6.6 \\
\hline Truck $\ldots \ldots \ldots \ldots$ & 90.6 & 85.0 & 68.0 \\
\hline Multimode $^{\mathrm{a}} \ldots \ldots \ldots$ & 20.3 & 25.9 & 8.8 \\
\hline Other $\ldots \ldots \ldots \ldots$ & 131.5 & -- & 99.3 \\
\hline Region Average . . . . & 20.7 & 24.5 & 10.7 \\
\hline \multicolumn{4}{|l|}{ South } \\
\hline Rail $\ldots \ldots \ldots \ldots$ & 23.5 & 21.8 & 14.7 \\
\hline Barge $\ldots \ldots \ldots \ldots$ & 11.8 & 7.7 & 7.5 \\
\hline Truck $\ldots \ldots \ldots$ & 713.3 & 306.1 & 72.2 \\
\hline Multimode $^{\mathrm{a}} \ldots \ldots \ldots$ & 24.3 & 19.9 & 16.0 \\
\hline Other $^{b} \ldots \ldots \ldots$ & -- & - &.- \\
\hline Region Average . . . . & 22.9 & 21.1 & 14.2 \\
\hline \multicolumn{4}{|l|}{ West } \\
\hline Rail .... & 22.5 & 34.1 & 20.8 \\
\hline Barge $\ldots \ldots \ldots \ldots$ & - & -- & -- \\
\hline Truck $\ldots \ldots \ldots$ & 170.9 & 271.4 & 198.2 \\
\hline Multimode $^{\mathrm{a}} \ldots \ldots \ldots$ & -- & - & -- \\
\hline Other $\ldots \ldots \ldots \ldots$ & 26.0 & 19.6 & 19.3 \\
\hline Region Average .... & 25.5 & 44.7 & 23.6 \\
\hline \multicolumn{4}{|l|}{ United States } \\
\hline Rail . . . . . . . . . . & 22.4 & 23.6 & 13.6 \\
\hline Barge $\ldots \ldots \ldots \ldots$ & 12.2 & 9.7 & 8.0 \\
\hline Truck ........... & 99.5 & 173.5 & 84.2 \\
\hline Multimode $^{\mathrm{a}} \ldots \ldots \ldots$ & 21.4 & 24.5 & 10.0 \\
\hline Other ${ }^{b} \ldots \ldots \ldots$ & 32.1 & 19.6 & 21.6 \\
\hline U.S. Total . . . . . . . & 22.1 & 23.7 & 12.9 \\
\hline
\end{tabular}

ancludes shipments that use any combination of rail, barge, and collier transportation.

bIncludes conveyor, tramway, slurry pipeline, and shipments for which mode is unknown.

-- = Not applicable.

Note: In computing the average rate per ton-mile, shipments for which the rate, distance, or tonnage were not reported were not used. Therefore, the average in this table cannot be $r \in$, licated by using the data in the average rate per ton and average distance tables, which utilized all available data.

Source: Energy Information Administration, Coal Transportation Rate Data Base.

\footnotetext{
${ }^{45}$ The average rate per ton-mile was particularly high for shipments to utilities in the West in 1986 because a large amount of coal was moved by truck.
} 
Figure 11. Average Utility Contract Coal Transportation Rate per Ton-Mile by Demand Region, 1979,1986 , and 1993

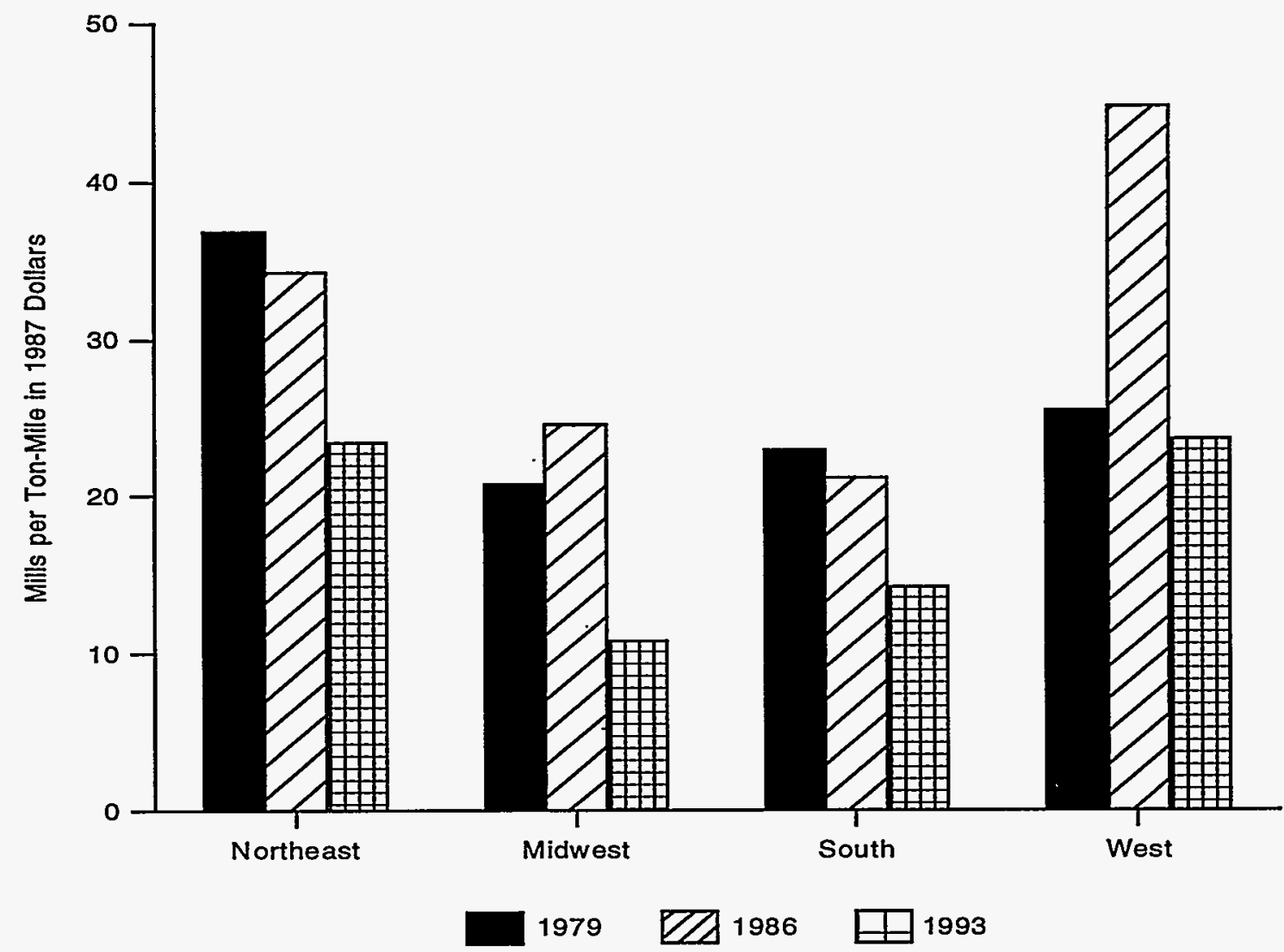

Source: Energy Information Administration, Coal Transportation Rate Data Base.

account for interregional differences in the average rate per ton-mile include differences in transportation fuel prices, the degree of intra- and inter-modal competition, and the strength of coal demand.

\section{Supply Regions}

The previous section of this chapter examined statistics for the contract coal that was shipped to electric utilities in various coal demand regions. Now the analysis turns to examining differences in contract coal transportation methods and rates for the contract coal that was shipped from three broad coal supply regions: Appalachia, the Interior Region, and the Western Region (Figure 12).

In 1979, 354 million tons of contract coal was delivered to electric utilities nationwide (Table 45). Utilities received 43 percent of their contract coal from Appalachia, 35 percent from the Western Region, and 22 percent from the Interior Region. By 1993, 51 percent of the contract coal delivered to utilities came from the Western Region, while the Interior region's share fell to 12 percent and Appalachia's share fell to 37 percent. This dramatic change illustrates the degree to which electric utilities shifted from the high- and mediumsulfur coals of the Interior and Appalachian regions to Western low-sulfur coals. Between 1979 and 1993, shipments of contract coal from the Western Region grew by 71 percent, while shipments from the Interior Region declined by 37 percent.

\section{Transportation Modes}

Rail was the predominant transportation mode for the contract coal shipments from all three supply regions, in all 3 years examined. In 1993, railroads hauled 64 percent of the coal from the Western Region, 56 percent of the coal from the Interior Region, and 50 percent of the coal from Appalachia. Conveyors, tramways, and coal slurry pipelines formed the second-largest group 
Figure 12. Supply Regions

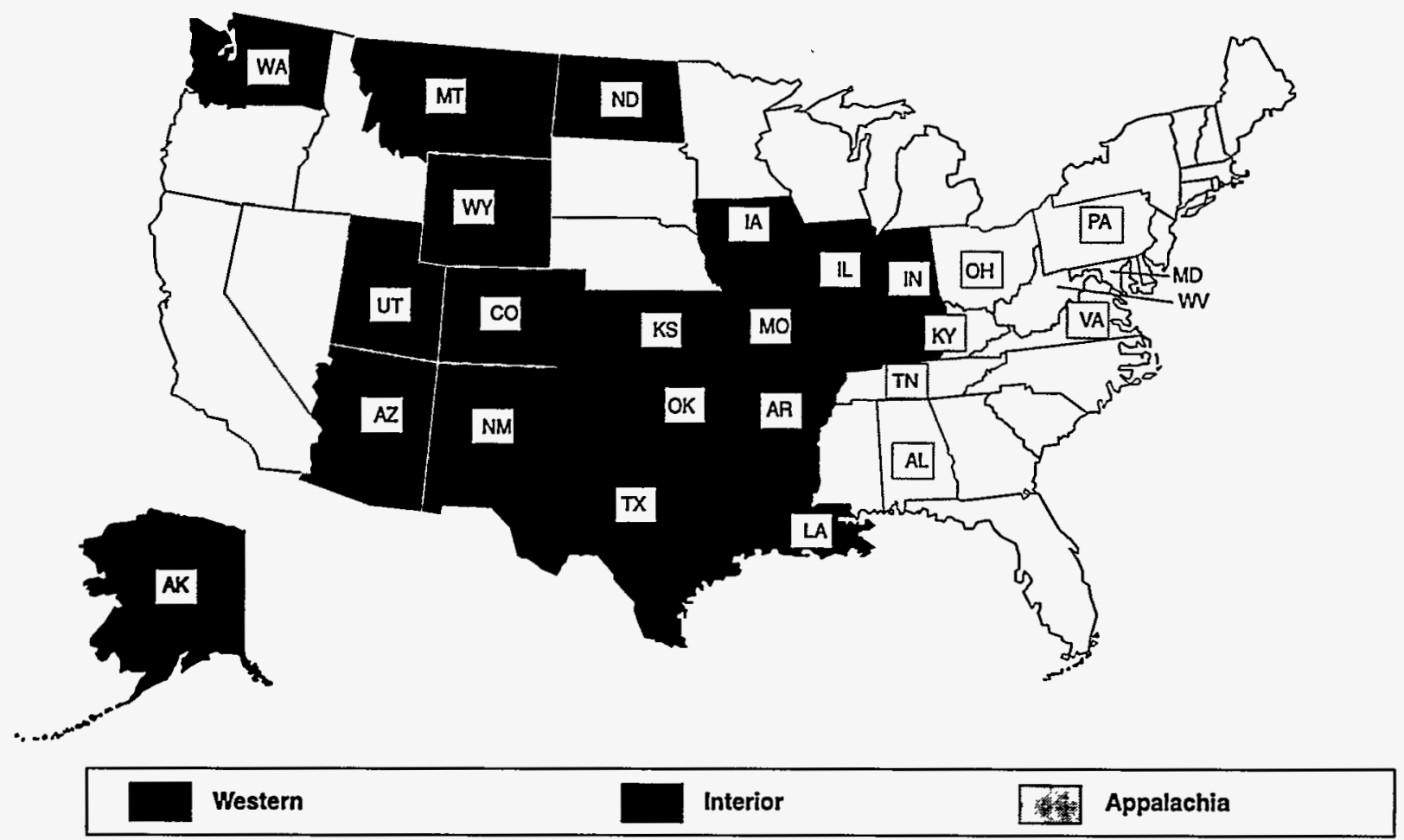

\section{Supply Regions}

\section{Appalachia}

Alabama

Kentucky, east

Maryland

Ohio

Pennsylvania

Tennessee

Virginia

West Virginia

\section{Interior}

Arkansas

Illinois

Indiana

lowa

Kansas

Kentucky, west

Louisiana

Missouri

Oklahoma

Texas

\section{Western}

Alaska

Arizona

Colorado

Montana

New Mexico

North Dakota

Utah

Washington

Wyoming of transporters (moving 14 percent of the contract coal, primarily 38 million tons in the Western Region). Barges were the third-largest transporters, moving about one-fifth of the contract coal supplied by both Appalachia and the Interior Region. Truck and multimodal movements each accounted for 9 percent of the U.S. total.
For the contract coal supplied by mines in Appalachia, rail and multimodal shipments (and their share of the region's total contract coal shipments) increased between 1979 and 1986, and then fell from 1986 through 1993. Barges lost market share between 1979 and 1986, but more than regained it by 1993. The shares of trucks and "other" transporters declined during both periods. 
Table 45. Utility Contract Coal Tonnage by Supply Region and Transportation Mode, 1979, 1986, and 1993

\begin{tabular}{|c|c|c|c|c|c|c|}
\hline \multirow[b]{2}{*}{ Supply Region } & \multicolumn{2}{|c|}{1979} & \multicolumn{2}{|c|}{1986} & \multicolumn{2}{|c|}{1993} \\
\hline & $\begin{array}{l}\text { Tonnage } \\
\text { (million } \\
\text { short tons) }\end{array}$ & $\begin{array}{l}\text { Percent } \\
\text { of Total }\end{array}$ & $\begin{array}{l}\text { Tonnage } \\
\text { (million } \\
\text { short tons) }\end{array}$ & $\begin{array}{l}\text { Percent } \\
\text { of Total }\end{array}$ & $\begin{array}{l}\text { Tonnage } \\
\text { (million } \\
\text { short tons) }\end{array}$ & $\begin{array}{l}\text { Percent } \\
\text { of Total }\end{array}$ \\
\hline \multicolumn{7}{|l|}{ Appalachia } \\
\hline Rail $\ldots \ldots \ldots \ldots \ldots \ldots$ & 72.0 & 47.6 & 97.4 & 54.8 & 78.8 & 50.5 \\
\hline Barge $\ldots \ldots \ldots \ldots \ldots \ldots$ & 23.9 & 15.8 & 18.7 & 10.5 & 34.6 & 22.2 \\
\hline Truck $\ldots \ldots \ldots \ldots \ldots \ldots \ldots$ & 15.0 & 9.9 & 15.3 & 8.6 & 11.0 & 7.0 \\
\hline Multimode $^{\mathrm{a}} \ldots \ldots \ldots \ldots \ldots$ & 17.0 & 11.2 & 21.4 & 12.1 & 15.1 & 9.7 \\
\hline$\ldots \ldots \ldots \ldots$ & 23.5 & 15.5 & 25.0 & 14.1 & 16.7 & 10.7 \\
\hline Region Total $\ldots \ldots \ldots \ldots \ldots$. & 151.4 & 100.0 & 177.7 & 100.0 & 156.2 & 100.0 \\
\hline \multicolumn{7}{|l|}{ Interior } \\
\hline Rail $\ldots \ldots \ldots \ldots \ldots \ldots \ldots$ & 52.6 & 67.1 & 44.6 & 47.0 & 27.6 & 55.5 \\
\hline Barge $\ldots \ldots \ldots \ldots \ldots \ldots$ & 10.1 & 12.9 & 11.1 & 11.7 & 10.2 & 20.5 \\
\hline Truck $\ldots \ldots \ldots \ldots \ldots \ldots$ & 4.0 & 5.1 & 9.0 & 9.5 & 5.3 & 10.7 \\
\hline Multimode $^{\mathrm{a}} \ldots \ldots \ldots \ldots \ldots \ldots$ & 6.2 & 8.0 & 8.1 & 8.6 & 2.1 & 4.2 \\
\hline Other $^{b} \ldots \ldots \ldots \ldots \ldots \ldots \ldots$ & 5.4 & 6.9 & 21.9 & 23.2 & 4.5 & 9.0 \\
\hline Region Total ............. & 78.4 & 100.0 & 94.8 & 100.0 & 49.6 & 100.0 \\
\hline \multicolumn{7}{|l|}{ Western } \\
\hline Rail .... & 82.1 & 66.3 & 88.7 & 58.9 & 136.1 . & 64.1 \\
\hline Truck $\ldots \ldots \ldots \ldots \ldots \ldots$ & 7.2 & 5.8 & 23.7 & 15.8 & 20.0 & 9.4 \\
\hline Multimode $^{\mathrm{a}}$ & 12.8 & 10.3 & 14.8 & 9.9 & 18.4 & 8.7 \\
\hline Other ${ }^{b} \ldots \ldots \ldots \ldots \ldots \ldots$ & 21.8 & 17.6 & 23.3 & 15.5 & 37.8 & 17.8 \\
\hline Region Total $\ldots \ldots \ldots \ldots \ldots$ & 123.9 & 100.0 & 150.5 & 100.0 & 212.2 & 100.0 \\
\hline \multicolumn{7}{|l|}{ United States } \\
\hline Rail ........ & 206.7 & 58.4 & 230.6 & 54.5 & 242.5 & 58.0 \\
\hline Barge $\ldots \ldots \ldots \ldots \ldots \ldots$ & 34.0 & 9.6 & 29.8 & 7.0 & 44.8 & 10.7 \\
\hline Truck $\ldots \ldots \ldots \ldots \ldots \ldots$ & 26.2 & 7.4 & 48.0 & 11.4 & 36.2 & 8.7 \\
\hline Multimode $^{\mathrm{a}} \ldots \ldots \ldots \ldots \ldots \ldots$ & 36.0 & 10.2 & 44.4 & 10.5 & 35.6 & 8.5 \\
\hline Other ${ }^{b} \ldots$ & 50.7 & 14.3 & 70.2 & 16.6 & 58.9 & 14.1 \\
\hline U.S. Total $\ldots \ldots \ldots \ldots \ldots \ldots$ & 353.7 & 100.0 & 423.0 & 100.0 & 418.0 & 100.0 \\
\hline
\end{tabular}

aIncludes shipments that use any combination of rail, barge, and collier transportation.

bIncludes conveyor, tramway, slurry pipeline, and shipments for which mode is unknown.

Source: Energy Information Administration, Coal Transportation Rate Data Base.

For the contract coal shipped from the Interior Region, rail shipments declined by about half between 1979 and 1993, and their share of the total fell from 67 percent to 56 percent. Over the same period, barge and truck shipments increased slightly, but their market shares rose significantly as total contract coal shipments from the region fell.
For the contract coal shipped from Western mines, railroads lost market share to trucks between 1979 and 1986 , but regained nearly all of it by 1993 . Although the tonnage transported in multimodal and "other" movements increased, their shares of the total declined or rose only slightly during both periods. 


\section{Contract Duration}

Long-term contracts were much more prevalent for coal supplied from the Western Region than from the other supply regions. This is because, in the West, coal mines and transportation infrastructure generally were not built unless long-term contracts were in hand. In 1993, 44 percent of the contract coal shipped from the Western Region was under long-term contract, compared with 9 percent in Appalachia and 20 percent in the Interior Region (Table 46). At the other end of the duration spectrum, coal under short-term contract was relatively important for shipments from Appalachia and the Interior Region.

Over time, an increasing proportion of the coal from all three supply regions was shipped under short-term contract. By 1993, 34 percent of the total contract tonnage was under short-term contract, compared with 22 percent in 1979. Between 1979 and 1993, excess coal production capacity arose, transportation options increased, and long-term contract prices became relatively high as other coal prices fell. As a result, even coal shipped from Western mines was covered increasingly by short-term contracts, and less by long-term contracts.

In 1993, the average contract duration (weighted by the annual coal tonnage shipped under the contract) was 25 years for shipments from the Western Region, compared with 15 years for Appalachian coal and 16 years for coal from the Interior Region (Table 47). Between 1979 and 1993, the average contract duration declined in all three supply regions. The change was greatest in the Interior Region, where the average duration fell by 22 percent.

\section{Average Distance Shipped}

Part of the increase in the average distance for contract coal shipments between 1979 and 1993 was due to the shift in supply sources from the Interior Region (where

Table 46. Utility Contract Coal Tonnage by Contract Duration and Supply Region, 1979, 1986, and 1993

\begin{tabular}{|c|c|c|c|c|c|c|c|}
\hline \multirow[b]{3}{*}{ Year/Supply Region } & \multicolumn{6}{|c|}{ Contract Duration } & \multirow{3}{*}{$\begin{array}{c}\text { All } \\
\text { Contracts } \\
\begin{array}{c}\text { Tonnage } \\
\text { (million } \\
\text { short tons) }\end{array}\end{array}$} \\
\hline & \multicolumn{2}{|c|}{$\begin{array}{c}\text { Short-Term } \\
\text { (10 Years or Less) }\end{array}$} & \multicolumn{2}{|c|}{$\begin{array}{l}\text { Medium-Term } \\
\text { (11-30 Years) }\end{array}$} & \multicolumn{2}{|c|}{$\begin{array}{l}\text { Long-Term } \\
\text { (More Than } 30 \text { Years) }\end{array}$} & \\
\hline & $\begin{array}{l}\text { Tonnage } \\
\text { (million } \\
\text { short tons) }\end{array}$ & $\begin{array}{l}\text { Percent } \\
\text { of Total }\end{array}$ & $\begin{array}{c}\text { Tonnage } \\
\text { (million } \\
\text { short tons) }\end{array}$ & $\begin{array}{l}\text { Percent } \\
\text { of Total }\end{array}$ & $\begin{array}{l}\text { Tonnage } \\
\text { (million } \\
\text { short tons) }\end{array}$ & $\begin{array}{l}\text { Percent } \\
\text { of Total }\end{array}$ & \\
\hline \multicolumn{8}{|l|}{1979} \\
\hline Appalachia & 48.6 & 32.1 & 82.3 & 54.4 & 20.5 & 13.6 & 151.4 \\
\hline Interior $\ldots \ldots \ldots \ldots$ & 9.5 & 12.1 & 54.9 & 70.1 & 14.0 & 17.8 & 78.4 \\
\hline Western .......... & 18.3 & 14.7 & 52.1 & 42.1 & 53.5 & 43.2 & 123.9 \\
\hline United States $\ldots \ldots$. & 76.3 & 21.6 & 189.3 & 53.5 & 88.0 & 24.9 & 353.7 \\
\hline \multicolumn{8}{|l|}{1986} \\
\hline Appalachia ........ & 76.6 & 43.1 & 82.6 & 46.5 & 18.5 & 10.4 & 177.7 \\
\hline Interior $\ldots \ldots \ldots \ldots$ & 30.4 & 32.1 & 46.8 & 49.3 & 17.6 & 18.6 & 94.8 \\
\hline Western .......... & 4.6 & 3.1 & 57.5 & 38.2 & 88.5 & 58.8 & 150.5 \\
\hline United States...$\ldots$ & 111.7 & 26.4 & 186.8 & 44.2 & 124.5 & 29.4 & 423.0 \\
\hline \multicolumn{8}{|l|}{1993} \\
\hline Appalachia....... & 68.6 & 44.0 & 73.6 & 47.2 & 13.9 & 8.9 & 156.2 \\
\hline Interior...$\ldots \ldots \ldots$ & 23.1 & 46.5 & 16.7 & 33.7 & 9.8 & 19.8 & 49.6 \\
\hline Western $\ldots \ldots \ldots \ldots$ & 48.3 & 22.8 & 69.7 & 32.9 & 94.2 & 44.4 & 212.2 \\
\hline United States $\quad . . \ldots \ldots$ & 140.1 & 33.5 & 160.1 & 38.3 & 117.9 & 28.2 & 418.0 \\
\hline
\end{tabular}

Source: Energy Information Administration, Coal Transportation Rate Data Base. 
Table 47. Average Utility Contract Duration by Supply Region and Transportation Mode, 1979, 1986, and 1993

(Years)

\begin{tabular}{|c|c|c|c|}
\hline Supply Region & 1979 & 1986 & 1993 \\
\hline \multicolumn{4}{|l|}{ Appalachia } \\
\hline 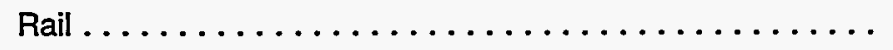 & 15.3 & 15.2 & 11.9 \\
\hline 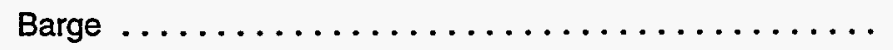 & 21.0 & 17.7 & 18.4 \\
\hline Truck $\ldots \ldots \ldots \ldots \ldots \ldots \ldots \ldots \ldots \ldots \ldots \ldots \ldots \ldots \ldots$ & 9.9 & 11.2 & 12.6 \\
\hline Multimode $^{\mathrm{a}} \ldots \ldots \ldots \ldots \ldots \ldots \ldots \ldots \ldots \ldots \ldots \ldots \ldots \ldots$ & 13.1 & 13.2 & 11.9 \\
\hline 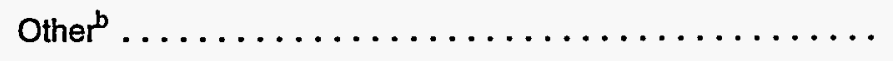 & 28.9 & 18.8 & 23.9 \\
\hline Region Average $\ldots \ldots \ldots \ldots \ldots \ldots \ldots \ldots \ldots$ & 17.5 & 15.4 & 14.7 \\
\hline \multicolumn{4}{|l|}{ Interior } \\
\hline 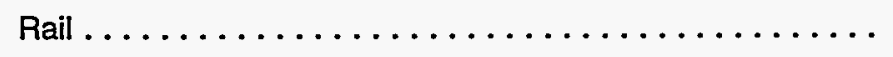 & 21.1 & 22.3 & 19.7 \\
\hline 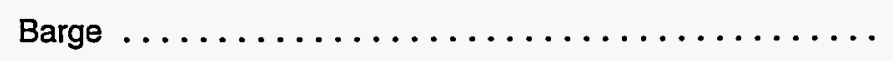 & 21.7 & 16.2 & 10.1 \\
\hline Truck $\ldots \ldots \ldots \ldots \ldots \ldots \ldots \ldots \ldots \ldots \ldots \ldots$ & 18.8 & 22.4 & 9.6 \\
\hline Multimode $^{a} \ldots \ldots \ldots \ldots \ldots \ldots \ldots \ldots \ldots \ldots \ldots$ & 14.2 & 21.2 & 14.3 \\
\hline 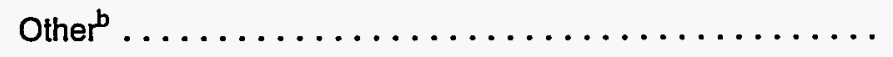 & 26.8 & 7.3 & 17.4 \\
\hline Region Average $\ldots \ldots \ldots \ldots \ldots \ldots \ldots \ldots \ldots$ & 20.9 & 18.0 & 16.2 \\
\hline \multicolumn{4}{|l|}{ Western } \\
\hline Rail $\ldots \ldots \ldots \ldots \ldots \ldots \ldots \ldots \ldots \ldots \ldots \ldots \ldots \ldots \ldots \ldots$ & 24.1 & 28.9 & 21.3 \\
\hline 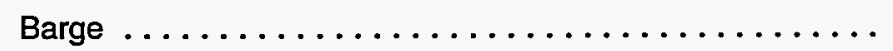 & -- & -- & -- \\
\hline Truck $\ldots \ldots \ldots \ldots \ldots \ldots \ldots \ldots \ldots \ldots \ldots \ldots \ldots \ldots \ldots \ldots \ldots \ldots \ldots$ & 39.4 & 37.5 & 30.4 \\
\hline 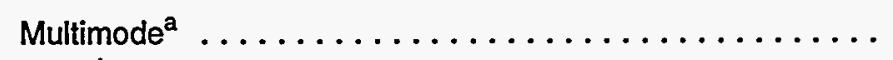 & 21.1 & 32.9 & 26.0 \\
\hline 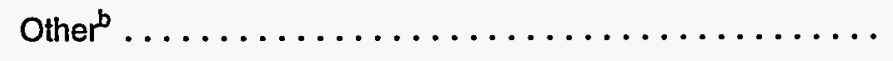 & 34.5 & 33.0 & 34.8 \\
\hline Region Average $\ldots \ldots \ldots \ldots \ldots \ldots \ldots \ldots \ldots$ & 26.5 & 31.3 & 25.0 \\
\hline \multicolumn{4}{|l|}{ United States } \\
\hline Rail ...... & 20.3 & 21.8 & 18.1 . \\
\hline 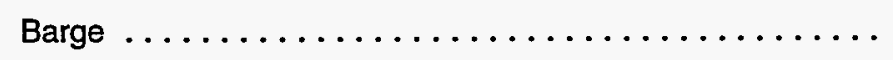 & 21.2 & 17.1 & $16.5^{\circ}$ \\
\hline 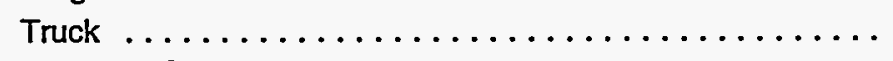 & 19.4 & 26.3 & 22.0 \\
\hline Multimode $^{\mathrm{a}} \ldots \ldots \ldots \ldots \ldots \ldots \ldots \ldots \ldots$ & 16.1 & 21.3 & 19.4 \\
\hline 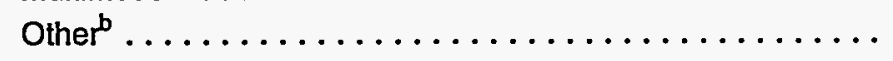 & 31.1 & 19.9 & 30.4 \\
\hline U.S. Average . . . . . . . . . . . . . . . . . . & 21.4 & 21.6 & 20.1 \\
\hline
\end{tabular}

ancludes shipments that use any combination of rail, barge, and collier transportation.

Includes conveyor, tramway, slurry pipeline, and shipments for which mode is unknown.

- = Not applicable.

Source: Energy Information Administration, Coal Transportation Rate Data Base.

the average shipping distance is relatively short) to the Western Region (where the average shipping distance is relatively long). However, part of the change was also due to the increased distance that coal was shipped from Appalachia and the Western Region.

As electric utilities turned toward low-sulfur coal to comply with State and Federal clean air laws, and as Western coal prices and transportation rates declined, Powder River Basin coal was shipped further towards the East and the South. The average distance for movements of contract coal from the Western Region increased from 769 miles in 1979 to 871 miles in 1993, an increase of 13 percent (Table 48). The average distance for multimodal shipments increased by 18 percent, to 1,569 miles.

Over the same period, the average shipping distance for contract coal from Appalachia rose from 260 miles to 324 miles. This 24-percent increase reflected a doubling 
Table 48. Average Distance Shipped Per Ton for Utility Contract Coal by Supply Region and Transportation Mode, 1979, 1986, and 1993 (Miles)

\begin{tabular}{|c|c|c|c|}
\hline Supply Region & 1979 & 1986 & 1993 \\
\hline \multicolumn{4}{|l|}{ Appalachia } \\
\hline Rail ........... & 333.6 & 335.9 & 386.6 \\
\hline Barge........ & 112.3 & 207.1 & 226.5 \\
\hline Truck ........... & 41.4 & 26.9 & 43.9 \\
\hline Multimode $^{\mathrm{a}} \ldots \ldots \ldots$ & 446.1 & 424.4 & 508.3 \\
\hline Other $^{b} \ldots \ldots \ldots$ & 8.2 & 7.0 & 10.0 \\
\hline Region Average $\ldots$ & 260.3 & 299.0 & 323.8 \\
\hline \multicolumn{4}{|l|}{ Interior } \\
\hline Rail . . . . . . . . . . & 158.4 & 158.9 & 97.3 \\
\hline Barge $\ldots . \ldots \ldots$. & 745.6 & 614.7 & 547.9 \\
\hline Truck .......... & 49.1 & 24.5 & 43.1 \\
\hline Multimode ${ }^{a}$ & 331.0 & 415.4 & 269.9 \\
\hline Other ${ }^{b}$. & -- & 7.5 & 7.5 \\
\hline Region Average ... & 244.4 & 231.9 & 173.9 \\
\hline \multicolumn{4}{|l|}{ Western } \\
\hline Rail . . . . . . . . . & 808.9 & 987.6 & 955.9 \\
\hline Barge $\ldots \ldots \ldots \ldots$ &.- & - & -- \\
\hline Truck ........... & 19.7 & 12.6 & 18.7 \\
\hline Multimode $^{\mathrm{a}} \ldots \ldots \ldots$ & $1,329.5$ & $1,422.2$ & $1,568.5$ \\
\hline Otherb. & 88.4 & 98.1 & 86.6 \\
\hline Region Average ... & 768.5 & 750.5 & 870.6 \\
\hline \multicolumn{4}{|l|}{ United States } \\
\hline Rail ....... & 479.2 & 530.6 & 671.3 \\
\hline Barge .... & 313.5 & 359.2 & 292.8 \\
\hline Truck ..... & 38.2 & 18.8 & 32.0 \\
\hline Multimode ${ }^{\mathrm{a}}$ & 751.2 & 658.0 & $1,053.5$ \\
\hline Other ${ }^{b} . .$. & 47.5 & 63.9 & 63.2 \\
\hline U.S. Average . . . . . . & 437.7 & 441.1 & 576.1 \\
\hline
\end{tabular}

Includes shipments that use any combination of rail, barge, and collier transportation.

'Includes conveyor, tramway, slurry pipeline, and shipments for which mode is unknown.

- = Not applicable.

Source: Energy Information Administration, Coal Transportation Rate Data Base.

in the average distance for barge movements, as well as a 16-percent increase in the average distance for rail shipments. Shipping distance increased as more of the region's coal was shipped to utilities in the South.
In contrast to these changes, the average distance for contract coal shipments from the Interior Region declined by 29 percent between 1979 and 1993. Primarily, this reflected a 39-percent fall in the average distance for rail hauls, from 158 miles to 97 miles. Most of the overall decline in average shipping distance occurred between 1986 and 1993, as reduced amounts of the region's high-sulfur coal were shipped to utilities in the South. Also, for shipments within or adjacent to the region, an increased proportion of the contract coal was delivered to utilities that were sited closer to the mines.

\section{Transportation Rate per Ton}

In 1993, the average transportation rate for the contract coal shipped from the Interior Region was $\$ 3.07$ per ton, compared to $\$ 6.91$ per ton for Appalachian coal and $\$ 9.76$ per ton for Western coal (Table 49, Figure 13). The low transportation cost for Interior Region coal was due primarily to the relatively short distance the coal was shipped, in particular, to the short rail hauls. Another important factor was the extensive use of lowcost barge transportation. The high transportation cost for shipments from the Western Region also reflected distance and transportation mode considerations. Average shipping distance for coal from the Western Region was much greater than for coal from the other supply regions. Barge transportation is not available in the West, although it is used in multimodal (rail/barge) shipments to other regions with waterways.

Between 1979 and 1993, the average transportation rate per ton fell substantially for shipments of contract coal from each of the three supply regions. Even though the average distance for shipments from the Western Region increased significantly between 1979 and 1993, the average transportation rate per ton fell by 36 percent. This was largely due to increased competition among the region's railroads and efficiency gains due to technological and operating improvements. Shorter average truck and conveyor movements also lowered transportation costs, as did efficiency gains in multimodal transportation.

For contract coal shipments from the Interior Region, the average rate per ton fell by 42 percent between 1979 and 1993, more than in any other supply region. Primarily, this decline was due to the substantial fall in the average distance the coal was shipped.

Average shipping distance increased for the contract coal shipped from Appalachia, so it was not a factor in the 19-percent fall in the average cost of transporting the coal from the region. The causal factors were the 
Table 49. Average Utility Contract Coal Transportation Rate Per Ton by Supply Region and Transportation Mode, 1979, 1986, and 1993 (1987 Dollars)

\begin{tabular}{|c|c|c|c|}
\hline Supply Region & 1979 & 1986 & 1993 \\
\hline \multicolumn{4}{|l|}{ Appalachia } \\
\hline Rail ............ & 10.44 & 11.03 & 8.77 \\
\hline Barge $: \ldots \ldots \ldots$ & 2.10 & 2.37 & 2.62 \\
\hline Truck $\ldots \ldots \ldots \ldots$ & 6.93 & 4.67 & 2.82 \\
\hline Multimode $^{\mathrm{a}} \ldots \ldots$ & 12.46 & 11.46 & 9.22 \\
\hline Other $^{b} \ldots \ldots \ldots \ldots$ & 1.58 & NA & 0.90 \\
\hline Region Average ... & 8.56 & 9.60 & 6.91 \\
\hline \multicolumn{4}{|l|}{ Interior } \\
\hline Rail ........... & 5.12 & 4.65 & 2.88 \\
\hline Barge .......... & 4.26 & 4.08 & 3.42 \\
\hline Truck .......... & 8.25 & 3.51 & 3.07 \\
\hline Multimode $^{a}$ & 7.33 & 5.72 & 4.23 \\
\hline Other $^{b} \ldots \ldots \ldots$ & -- & -- & $\ldots$ \\
\hline Region Average ... & 5.32 & 4.52 & 3.07 \\
\hline \multicolumn{4}{|l|}{ Western } \\
\hline Rail .... & 14.62 & 18.75 & 10.26 \\
\hline Barge $\ldots \ldots \ldots \ldots$ & -- & -- & .- \\
\hline$\ldots \ldots$ & 5.45 & 4.64 & 4.10 \\
\hline Multimode ${ }^{a}$ & 24.99 & 20.49 & 12.49 \\
\hline Other $^{b} \ldots \ldots \ldots \ldots$ & 4.44 & 2.74 & 2.52 \\
\hline Region Average ... & 15.24 & 13.59 & 9.76 \\
\hline \multicolumn{4}{|l|}{ United States } \\
\hline Rail ...... & 10.80 & 11.00 & 8.93 \\
\hline Barge . & 2.73 & 2.88 & 2.81 \\
\hline Truck & 6.85 & 4.31 & 3.56 \\
\hline Multimode $^{\mathrm{a}} \ldots \ldots \ldots$ & 16.00 & 13.61 & 10.63 \\
\hline Other ${ }^{b}$. & 2.63 & 2.75 & 1.88 \\
\hline U.S. Average . . . . . . & 10.11 & 9.45 & 7.83 \\
\hline
\end{tabular}

ancludes shipments that use any combination of rail, barge, and collier transportation.

'Includes conveyor, tramway, slurry pipeline, and shipments for which mode is unknown.

-- = Not applicable.

NA $=$ Not available.

Source: Energy Information Administration, Coal Transportation Rate Data Base.

substantial increase in low-cost barge movements and gains in rail transportation as rail rates were falling.

Between 1979 and 1993, the average cost for shipping each ton of contract coal declined for all transportation
Figure 13. Average Utility Contract Coal Transportation Rate per Ton by Supply Region, 1979, 1986, and 1993

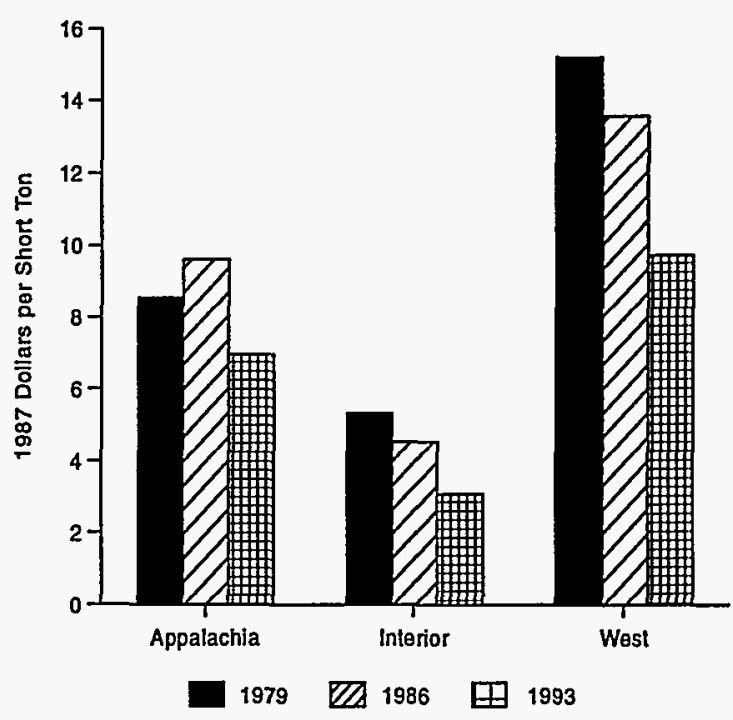

Source: Energy Information Administration, Coal Transportation Rate Data Base.

modes in every supply region, with one exception. The average transportation cost for barge movements from Appalachia increased by one-quarter, because the average shipping distance doubled.

Because of wide interregional differences in average shipping distance, transportation cost, and minemouth coal prices, coal transportation cost represents a very different proportion of the delivered price of the contract coal shipped from each of the three supply regions. In 1993, transportation cost accounted for 51 percent of the average delivered price for Western coal (Table 50). This percentage is high for two basic reasons: the relatively long distance Western coal is shipped, which increases the transportation cost, and the low cost of mining Western coal reserves, which lowers the minemouth price.

In contrast, for the contract coal shipped from the Interior Region, where the average shipping distance is much lower and minemouth prices are higher, transportation cost represented only 12 percent of the average delivered price. The proportion for Appalachian coal falls between the other two regions, with transportation cost representing 21 percent of the average delivered price in 1993. 
Table 50. Utility Contract Coal Transportation Cost as a Percentage of Delivered Price by Supply Region, 1979-1993

(Percent)

\begin{tabular}{l|c|c|c|c|c|c|c|c|c|c|c|c|c|c|c}
\hline Supply Region & 1979 & 1980 & 1981 & 1982 & 1983 & 1984 & 1985 & 1986 & 1987 & 1988 & 1989 & 1990 & 1991 & 1992 & 1993 \\
\hline Appalachian . . . . & 16.8 & 17.0 & 17.8 & 18.2 & 19.9 & 21.1 & 18.7 & 21.3 & 21.5 & 20.9 & 20.4 & 20.5 & 20.1 & 20.0 & 20.8 \\
Interior ........ & 13.9 & 13.6 & 14.7 & 13.7 & 14.5 & 17.1 & 12.7 & 13.2 & 13.4 & 12.6 & 11.9 & 12.2 & 13.7 & 12.6 & 12.3 \\
Wester . ...... & 51.7 & 50.8 & 51.7 & 50.0 & 48.9 & 49.5 & 50.1 & 45.4 & 45.2 & 58.8 & 58.3 & 54.1 & 52.5 & 52.4 & 50.9 \\
United States ... & 24.9 & 25.2 & 27.3 & 25.6 & 27.2 & 29.0 & 26.6 & 25.3 & 25.0 & 30.7 & 30.7 & 28.9 & 28.3 & 29.4 & 31.2 \\
\hline
\end{tabular}

Source: Energy Information Administration, Coal Transportation Rate Data Base.

For the contract coal shipped from Appalachia, the ratio of transportation cost to delivered price increased from 17 percent in 1979 to 21 percent in 1984, as the coal was shipped longer distances. Generally, the ratio held fairly steady between 1984 and 1993, as the increase in shipping distance moderated and transportation rates fell.

For the contract coal shipped from the Interior and Western regions, transportation cost represented a slightly lower percentage of the average delivered price in 1993 than in 1979. However, for the contract coal from the three supply regions combined, the ratio of transportation cost to delivered price increased from 25 percent in 1979 to 31 percent in 1993. This significant increase was due not only to the increased ratio in Appalachia, but also the substitution of Western coal (which has a high transportation cost component) for coal from the Interior Region (which has a much lower transportation cost component).

\section{Transportation Rate per Ton-Mile}

The average transportation rate per ton-mile for contract coal differs widely across the various coal supply regions and transportation modes. In 1993, the average rate ranged from 4 mills ( 0.4 cent) per ton-mile for barge shipments from mines in the Interior Region to 140 mills (14 cents) per ton-mile for truck shipments from Western mines (Table 51, Figure 14).

Rail rates are lowest for the coal shipped from the Western Region, since the longer distance of the shipments spreads the fixed costs over a greater number of ton-miles. Historically, rail transportation rates have been higher for Appalachian coal than for coal from the Interior Region. However, between 1986 and 1993, this situation was reversed, as Appalachian rates fell by 26 percent and Interior rates rose by 7 percent, due to changes in shipping distance. Interregional differences in the transportation rate per ton for truck and multimodal shipments also reflect differences in the average distance the coal was shipped.

Between 1979 and 1993 (principally, between 1986 and 1993), the average contract coal transportation rate per ton-mile fell for every transportation mode in each coal supply region. In most cases, this reflected increased average shipping distances. The percentage decline in the transportation rate was greatest for multimodal shipments from the Western Region. Rail rates also fell more for shipments of Western coal than for coal from Appalachia and the Interior Region. For all modes combined, the average rate per ton-mile fell by 41 percent in the Western Region, compared to 36-percent declines in each of the other coal supply regions.

\section{Summary}

In 1993, 43 percent of the contract coal was shipped to electric utilities in the Midwest and 32 percent went to utilities in the South. Between 1979 and 1993, shipments to utilities in the West grew most rapidly, reaching 18 percent of the total in 1993. Utilities in the Northeast received a relatively small and declining share of the total.

Railroads were the predominant contract coal transporters, especially in the South, where they hauled 71 percent of the contract coal to utilities in 1993. Barges hauled 25 percent of the contract coal to utilities in the Northeast, and 17 million tons (13 percent) of the coal to utilities in the South. Conveyor transportation was important in the West.

Shipping distance has a substantial impact on coal transportation costs: the greater the distance, the greater 
Table 51. Average Utility Contract Coal Transportation Rate per Ton-Mile by Supply Region and Transportation Mode, 1979, 1986, and 1993 (Mills in 1987 Dollars)

\begin{tabular}{|c|c|c|c|}
\hline Supply Region & 1979 & 1986 & 1993 \\
\hline \multicolumn{4}{|l|}{ Appalachia } \\
\hline Rail $\ldots \ldots \ldots \ldots$ & 32.1 & 30.4 & 22.5 \\
\hline Barge $\ldots \ldots \ldots \ldots$ & 19.0 & 12.1 & 10.3 \\
\hline Truck .......... & 83.3 & 105.8 & 38.4 \\
\hline Multimode $^{\mathrm{a}} \ldots \ldots \ldots$ & 29.1 & 30.2 & 17.1 \\
\hline Other $^{b} \ldots \ldots \ldots \ldots$ & 131.5 & -- & 99.3 \\
\hline Region Average . . . & 31.1 & 29.2 & 19.8 \\
\hline \multicolumn{4}{|l|}{ Interior } \\
\hline Rail . . . . . . . . . & 31.1 & 28.3 & 30.2 \\
\hline Barge $\ldots \ldots \ldots \ldots$ & 8.8 & 7.6 & 4.3 \\
\hline Truck ......... & 89.3 & 126.6 & 64.2 \\
\hline Multimode $^{a} \ldots \ldots \ldots$ & 19.9 & 15.4 & 16.4 \\
\hline Other $^{b} \ldots \ldots \ldots \ldots$ & - & - & - \\
\hline Region Average $\ldots$. & 24.2 & 22.6 & 15.4 \\
\hline \multicolumn{4}{|l|}{ Western } \\
\hline Rail ............ & 18.0 & 17.9 & 11.0 \\
\hline Barge $\ldots \ldots \ldots \ldots$ & -- & - & -- \\
\hline Truck $\ldots \ldots \ldots \ldots$ & 170.9 & 269.0 & 140.4 \\
\hline Multimode $^{a} \ldots \ldots \ldots$ & 18.3 & 17.3 & 8.1 \\
\hline Other $^{b} \ldots \ldots \ldots \ldots$ & 26.0 & 19.6 & 19.3 \\
\hline Region Average .... & 18.3 & 19.5 & 10.8 \\
\hline \multicolumn{4}{|l|}{ United States } \\
\hline Rail . . . . . . . . . . & 22.4 & 23.6 & 13.6 \\
\hline Barge ........... & 12.2 & 9.7 & 8.0 \\
\hline Truck ........... & 99.5 & 173.5 & 84.2 \\
\hline Multimode $^{a} \ldots \ldots \ldots$ & 21.4 & 24.5 & 10.0 \\
\hline Other $^{b} \ldots \ldots \ldots \ldots$ & 32.1 & 19.6 & 21.6 \\
\hline U.S. Average . . . . . . & 22.1 & 23.7 & 12.9 \\
\hline
\end{tabular}

ancludes shipments that use any combination of rail, barge, and collier transportation.

bincludes conveyor, tramway, slurry pipeline, and shipments for which mode is unknown.

- = Not applicable.

Note: In computing the average rate per ton-mile, shipments for which the rate, distance, or tonnage were not reported were not used. Therefore, the averages in this table cannot be replicated by using the data in the average rate per ton and average distance tables.

Source: Energy Information Administration, Coal Transportation Rate Data Base.
Figure 14. Average Utility Contract Coal Transportation Rate per Ton-Mile by Supply Region, 1979, 1986, and 1993

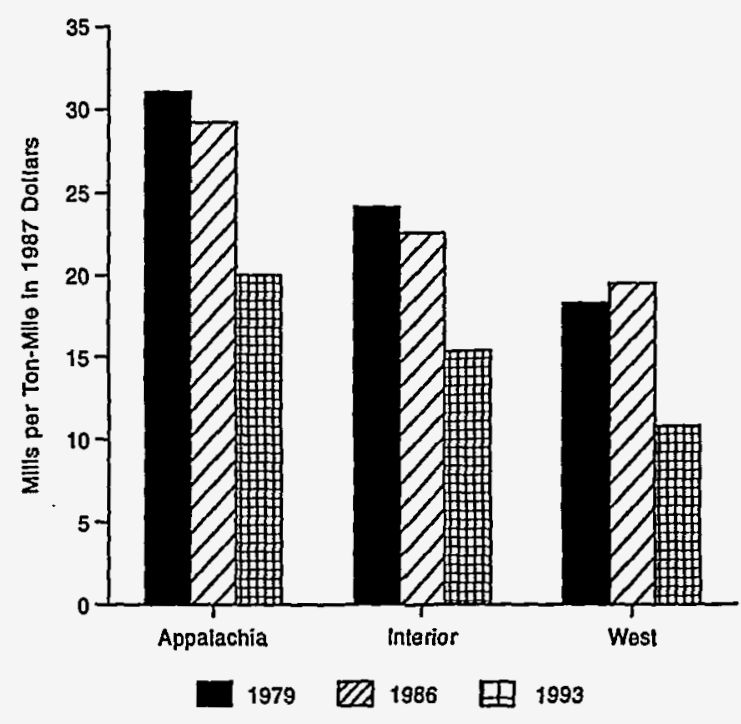

Source: Energy Information Administration, Coal Transportation Rate Data Base.

the transportation cost per ton. The greater the distance, the lower is the cost per ton-mile, because the fixed costs that do not vary with distance are spread over a greater number of miles. In 1993, for all transportation modes combined, the average shipping distance for contract coal was 675 miles for shipments to utilities in the Midwest, 660 miles to utilities in the South, 278 miles for deliveries to the Northeast, and 169 miles for deliveries to the West. Between 1979 and 1993, the average shipping distance increased in all of the demand regions.

Regional differences in coal transportation costs reflect the differences in the average shipping distance. The average cost per ton for shipping contract coal is highest for the coal going to utilities in South, generally in long-distance moves from Appalachia or the Western Region. The lowest cost per ton is for shipments to Western power plants, characterized by short conveyor, rail, or truck movements.

Between 1979 and 1993, the average contract coal transportation rate per ton increased slightly in the West, partly due to a shift from short truck hauls to longer rail movements. The average rate per ton fell in all other demand regions, as efficiency gains more than 
offset the increases in shipping distance. However, as coal prices fell faster than transportation rates, transportation cost represented an increasing percentage of the average delivered coal price in all demand regions.

Between 1979 and 1993, electric utilities shifted their contract coal purchases from the high- and mediumsulfur coals of the Interior and Appalachian regions to Western low-sulfur coals. By 1993, 51 percent of the contract coal delivered to electric utilities came from the Western Region, compared with 35 percent in 1979. Only 12 percent came from the Interior Region, down from 22 percent in 1979. Appalachia's share fell from 43 percent to 37 percent.

In 1993, more than half of the contract coal in each of the three supply regions was shipped by rail. Conveyors were the next most important coal movers for shipments from the Western Region, and barges were the second-largest coal transporters for shipments from Appalachia and the Interior Region.

In 1993, the average distance for contract coal shipments was 871 miles for coal from the Western Region, 324 miles for coal from Appalachia, and 174 miles for coal from the Interior Region. Between 1979 and 1993, the average distance for shipments from the Western Region rose by 13 percent, as Powder River Basin coal was shipped farther eastward and southward. The average distance for shipments from Appalachia increased by 24 percent, primarily because of longer barge movements to utilities in the South. In contrast, the average distance for shipments from the Interior Region fell by 29 percent, as less of the region's coal was shipped to utilities in the South.

In 1993, the average contract coal transportation rate was $\$ 3.07$ per ton for Interior coal, $\$ 6.91$ per ton for Appalachian coal, and $\$ 9.76$ per ton for Western coal (all in 1987 dollars). These rates reflected the regional differences in average shipping distance. Between 1979 and 1993, the average transportation rate fell for coal from each of the three supply regions, but for different reasons. In the Western Region, transportation rates fell primarily because of increased competition among railroads and the substantial productivity gains made by the railroads. In the Interior Region, the fall in the average rate per ton primarily was due to the decline in average shipping distance. In Appalachia, the fall in the average transportation rate was largely due to the increase in low-cost barge shipments.

In 1993, transportation cost accounted for 51 percent of the average delivered price for contract coal from the Western Region, 21 percent of the average delivered price for coal from Appalachia, and 12 percent of the average delivered price for coal from the Interior Region. The high transportation cost component for Western coal is due to its relatively low minemouth price as well as to the relatively long distance it is shipped. Between 1979 and 1993, the ratio of transportation cost to delivered price fell slightly for the contract coal shipped from the Interior and Western Regions, while it increased for shipments from Appalachia. 



\section{Distribution Patterns and Regional Profiles}

The previous chapter described contract coal transportation trends from two points of view: the region where the coal was burned by electric utilities and the region where the coal was produced. In this chapter, distribution patterns among the various supply and demand (or origin and destination) regions are examined. Significant differences or changes in contract coal shipments and transportation rates between pairs of supply and demand regions are discussed. Finally, contract coal transportation profiles are drawn for each of the four demand regions and three supply regions.

\section{Distribution Patterns}

\section{Contract Coal Tonnage}

The electric utility contract coal data illustrate the changing trends in coal distribution. Of the contract coal shipped in 1979, 169 million tons (nearly half of the total) went to utilities in the Midwest (Table 52). Most of that coal came from the Interior and Western supply regions. About one-fifth of the total was shipped from Appalachia to utilities in the South.

Between 1979 and 1986, rapid population growth and economic development in the South led to a substantial increase in electricity demand. By 1986, more contract coal was shipped from Appalachia to the South than between any other pair of supply and demand regions, bringing the South's contract coal receipts to 39 percent of the national total.

Between 1986 and 1993, electric utilities increased their purchases of low-sulfur coal to meet the sulfur dioxide emissions limits imposed by Federal and State clean air legislation. In particular, Midwestern utilities switched from the Interior Region's high-sulfur coal to low-sulfur coal from the Western Region. By 1993, Midwestern utilities obtained 55 percent of their contract coal from the Western Region, compared with 35 percent in 1986. Overall, the Western Region supplied 51 percent of the contract coal to utilities in 1993, replacing Appalachia as the leading supply region.

\section{Average Contract Duration}

Generally, coal supply contracts are of longer duration where electric utilities have few alternative supply sources for a power plant, or where large investments in mining facilities or transportation infrastructure would not be made without a secure market for the coal. Contracts tend to be shorter where there are numerous potential coal suppliers and purchasers. In 1993, the average contract duration ranged from 11 years for shipments from Appalachia to Northeast utilities to 31 years for shipments from Western mines to utilities in the South (Table 53).

Average contract duration was shorter in 1993 than in 1979 in all regions except the South, where the average contract duration increased from 18 to 19 years. Over time, Southern utilities took increasing proportions of their coal under long-term contracts with Western coal producers. Although Western utilities and other utilities that use Western coal continued to take more coal under long-term contract than consumers in any other region, the average contract duration for Western coals declined substantially between 1986 and 1993.

\section{Transportation Rate per Ton}

In 1993, the average transportation rate was highest for contract coal shipments from the Western Region to utilities in the South, at $\$ 13.43$ per ton (Table 54). This high transportation cost reflected the long distance the coal was shipped. In contrast, for the relatively short movements from Interior Region mines to Midwest utilities, the average rate was only $\$ 2.81$ per ton. The average transportation cost was also low in the West, where the distance from the mine to the power plant typically is short. These distribution data clearly show that shipping distance is the most important factor influencing the cost of transporting coal from the producer to the consumer.

Between 1979 and 1993, the average transportation rate per ton fell for shipments between every combination of supply and demand region (or origin-destination 
Table 52. Utility Contract Coal Tonnage Shipped Between Supply and Demand Regions, 1979, 1986, and 1993

(Million Short Tons)

\begin{tabular}{|c|c|c|c|c|c|}
\hline \multirow[b]{2}{*}{ Year/Supply Region } & \multicolumn{4}{|c|}{ Demand Region } & \multirow[b]{2}{*}{ U.S. Total } \\
\hline & Northeast & Midwest & South & West & \\
\hline \multicolumn{6}{|l|}{1979} \\
\hline Appalachia .... & 30.1 & 46.0 & 75.3 & -- & 151.4 \\
\hline Interior $\ldots \ldots \ldots \ldots \ldots \ldots \ldots \ldots$ & -- & 62.6 & 15.8 & - & 78.4 \\
\hline Western $\ldots \ldots \ldots$ & -- & 60.9 & 12.4 & 50.6 & 123.9 \\
\hline U.S. Total $\ldots \ldots \ldots \ldots \ldots \ldots \ldots$ & 30.1 & 169.4 & 103.6 & 50.6 & 353.7 \\
\hline \multicolumn{6}{|l|}{1986} \\
\hline Appalachia .. & 23.7 & 51.8 & 102.1 & -- & 177.7 \\
\hline Interior $\ldots \ldots \ldots \ldots \ldots \ldots \ldots \ldots$ & - & 61.2 & 33.6 & -- & 94.8 \\
\hline Western $\ldots \ldots \ldots \ldots \ldots \ldots \ldots$ & -- & 61.5 & 28.1 & 60.9 & 150.5 \\
\hline U.S. Total $\ldots \ldots \ldots \ldots \ldots \ldots \ldots$ & 23.7 & 174.4 & 163.9 & 60.9 & 423.0 \\
\hline \multicolumn{6}{|l|}{1993} \\
\hline Appalachia .. & 31.7 & 43.4 & 81.0 & -- & 156.2 \\
\hline Interior $\ldots \ldots \ldots \ldots \ldots \ldots \ldots \ldots$ & -- & 37.2 & 12.5 & -- & 49.6 \\
\hline Western $\ldots \ldots \ldots \ldots \ldots \ldots \ldots$ & -- & 100.2 & 38.8 & 73.2 & 212.2 \\
\hline U.S. Total $\ldots \ldots \ldots \ldots \ldots \ldots \ldots \ldots$ & 31.7 & 180.8 & 132.4 & 73.2 & 418.1 \\
\hline
\end{tabular}

$--=$ Not applicable.

Note: Totals may not equal sum of components because of independent rounding.

Source: Energy Information Administration, Coal Transportation Rate Data Base.

Table 53. Average Duration of Utility Coal Supply Contracts Between Supply and Demand Regions, 1979,1986 , and 1993

(Years)

\begin{tabular}{|c|c|c|c|c|c|}
\hline \multirow[b]{2}{*}{ Year/Supply Region } & \multicolumn{5}{|c|}{ Demand Region } \\
\hline & Northeast & Midwest & South & West & U.S. Total \\
\hline \multicolumn{6}{|l|}{1979} \\
\hline Appalachia $\ldots \ldots \ldots \ldots \ldots \ldots$ & 13.3 & 18.1 & 14.8 & -- & 15.4 \\
\hline Interior $\ldots \ldots \ldots \ldots \ldots \ldots \ldots$ & -- & 20.4 & 20.7 & - & 20.5 \\
\hline Western $\ldots \ldots \ldots \ldots$ & -- & 20.6 & 28.4 & 32.1 & 24.8 \\
\hline United States $\ldots \ldots \ldots \ldots \ldots \ldots$ & 13.3 & 20.0 & 17.6 & 32.1 & 19.8 \\
\hline \multicolumn{6}{|l|}{1986} \\
\hline Appalachia & 9.7 & 18.0 & 14.3 & -- & 14.9 \\
\hline Interior $\ldots \ldots \ldots \ldots \ldots \ldots \ldots$ & -- & 20.7 & 23.4 & -- & 21.3 \\
\hline$\ldots \ldots \ldots \ldots \ldots \ldots \ldots$ & -- & 27.8 & 30.5 & 35.1 & 30.9 \\
\hline United States $\ldots \ldots \ldots \ldots \ldots$ & 9.7 & 22.3 & 19.0 & 35.1 & 22.0 \\
\hline \multicolumn{6}{|l|}{1993} \\
\hline Appalachia $\ldots \ldots \ldots \ldots \ldots \ldots$ & 11.2 & 14.5 & 14.0 & -- & 13.5 \\
\hline Interior $\ldots \ldots \ldots \ldots \ldots \ldots \ldots$ & -- & 17.8 & 10.2 & -- & 16.1 \\
\hline Western..$\ldots \ldots \ldots \ldots \ldots \ldots$ & -- & 19.4 & 31.4 & 22.8 & 22.9 \\
\hline United States $\ldots \ldots \ldots \ldots \ldots \ldots$ & 11.2 & 18.0 & 19.3 & 22.8 & 18.4 \\
\hline
\end{tabular}

$--=$ Not applicable.

Source: Energy Information Administration, Coal Transportation Rate Data Base. 
Table 54. Average Utility Contract Coal Transportation Rate per Ton Between Supply and Demand Regions, 1979, 1986, and 1993 (1987 Dollars)

\begin{tabular}{|c|c|c|c|c|c|}
\hline \multirow[b]{2}{*}{ Year/Supply Region } & \multicolumn{4}{|c|}{ Demand Region } & \multirow[b]{2}{*}{ U.S. Total } \\
\hline & Northeast & Midwest & South & West & \\
\hline \multicolumn{6}{|l|}{1979} \\
\hline Appalachia $\ldots \ldots \ldots \ldots \ldots \ldots \ldots$ & 9.40 & 9.61 & 8.79 & -- & 9.12 \\
\hline Interior $\ldots \ldots \ldots \ldots \ldots \ldots \ldots \ldots$ & -- & 4.93 & 6.68 & -- & 5.32 \\
\hline Western $\ldots \ldots \ldots \ldots \ldots \ldots \ldots$ & -- & 18.55 & 20.01 & 4.69 & 15.86 \\
\hline U.S. Total $\ldots \ldots \ldots \ldots \ldots \ldots$ & 9.40 & 11.78 & 10.02 & 4.69 & 10.51 \\
\hline \multicolumn{6}{|l|}{1986} \\
\hline Appalachia $\ldots \ldots \ldots \ldots \ldots \ldots \ldots$ & 8.40 & 9.32 & 10.26 & -- & 9.60 \\
\hline Interior $\ldots \ldots \ldots \ldots \ldots \ldots \ldots \ldots$ & -- & 4.00 & 6.11 & -- & 4.52 \\
\hline Western $\ldots \ldots \ldots \ldots \ldots \ldots \ldots$ & - & 16.09 & 24.27 & 5.85 & 15.66 \\
\hline U.S. Total $\ldots \ldots \ldots \ldots \ldots \ldots \ldots$ & 8.40 & 8.25 & 12.76 & 5.85 & 9.77 \\
\hline \multicolumn{6}{|l|}{1993} \\
\hline Appalachia & 8.18 & 4.93 & 8.03 & -- & 7.22 \\
\hline Interior $\ldots \ldots \ldots \ldots \ldots \ldots \ldots \ldots$ & -- & 2.81 & 4.15 & -- & 3.07 \\
\hline Western $\ldots \ldots \ldots \ldots \ldots \ldots \ldots \ldots$ & -- & 10.46 & 13.43 & 5.39 & 10.21 \\
\hline U.S. Total $\ldots \ldots \ldots \ldots \ldots \ldots \ldots$ & 8.18 & 7.67 & 9.50 & 5.39 & 8.13 \\
\hline
\end{tabular}

-- = Not applicable.

Source: Energy Information Administration, Coal Transportation Rate Data Base.

pair), with one exception. The exception was for shipments from Western mines to utilities in the West, for which the average transportation rate rose from $\$ 4.69$ to $\$ 5.39$ per ton. In absolute terms, the decline was greatest ( $\$ 7$ to $\$ 8$ per ton) for shipments from the Western Region to utilities in the Midwest and the South. In percentage terms, the decline was greatest ( 49 percent) for shipments from Appalachia to utilities in the Midwest.

\section{Transportation Rate per Ton-Mile}

Generally, the transportation rate per ton-mile varies inversely with the distance the coal is shipped. Because some of the costs involved in coal transportation remain the same no matter how far the coal is shipped, it usually costs less per mile to transport coal long distances. In 1993, the average rate per ton-mile for transporting contract coal to electric utilities was lowest for shipments from Interior mines to utilities in the South and from Western Region mines to utilities in the Midwest, at less than 10 mills ( 1 cent) per ton-mile
(Table 55). In contrast to these movements, for which the distance is relatively long, the average rate was about 23 mills ( 2.3 cents) per ton-mile for shipments from Appalachian mines to nearby Northeastern utilities, and from Western mines to utilities in the West.

Between 1979 and 1993, the average contract coal transportation rate per ton-mile declined for shipments from each supply region to any of the demand regions. In percentage terms, the decline was greatest ( 57 percent) for shipments from the Interior Region to utilities in the South. This drop probably was partly due to the increased use of low-cost barge transportation. The fall in the rate per ton-mile was also relatively great (48 percent) for shipments from the Western Region to midwestern utilities, which also increased their use of barges. In fact, the decline in the average contract coal transportation cost per ton-mile was significant for shipments between all of the origin-destination pairs examined, except for shipments from the Western Region to utilities in the West, where high-cost truck transportation was used more extensively in 1993 than in 1979. 
Table 55. Average Utility Contract Coal Transportation Rate per Ton-Mile Between Supply and Demand Regions, 1979, 1986, and 1993

(Mills in 1987 Dollars)

\begin{tabular}{|c|c|c|c|c|c|}
\hline \multirow[b]{2}{*}{ Year/Supply Region } & \multicolumn{4}{|c|}{ Demand Region } & \multirow[b]{2}{*}{ U.S. Total } \\
\hline & Northeast & Midwest & South & West & \\
\hline \multicolumn{6}{|l|}{1979} \\
\hline Appalachia & 36.8 & 29.7 & 30.4 & -- & 31.1 \\
\hline Interior $\ldots \ldots \ldots \ldots \ldots \ldots \ldots \ldots$ & -- & 28.1 & 18.1 & -- & 24.2 \\
\hline Western $\ldots \ldots \ldots \ldots \ldots \ldots \ldots \ldots$ & -- & 18.2 & 16.5 & 25.5 & 18.3 \\
\hline U.S. Total $\ldots \ldots \ldots \ldots \ldots \ldots \ldots$ & 36.8 & 20.7 & 22.9 & 25.5 & 22.1 \\
\hline \multicolumn{6}{|l|}{1986} \\
\hline Appalachia & 34.2 & 28.6 & 28.2 & -- & 29.2 \\
\hline Interior $\ldots \ldots$. & -- & 28.9 & 15.8 & -- & 22.6 \\
\hline Western $\ldots \ldots \ldots \ldots \ldots \ldots \ldots \ldots$ & -- & 17.2 & 17.4 & 44.7 & 19.5 \\
\hline U.S. Total $\ldots \ldots \ldots \ldots \ldots \ldots \ldots$ & 34.2 & 24.5 & 21.1 & 44.7 & 23.7 \\
\hline \multicolumn{6}{|l|}{1993} \\
\hline Appalachia $\ldots \ldots \ldots \ldots \ldots \ldots \ldots$ & 23.4 & 18.0 & 19.4 & -- & 19.8 \\
\hline Interior $\ldots \ldots \ldots \ldots \ldots \ldots \ldots \ldots$ & - & 20.2 & 7.8 & -- & 15.4 \\
\hline Western $\ldots \ldots \ldots \ldots \ldots \ldots \ldots \ldots$ & -- & 9.5 & 11.4 & 23.6 & 10.8 \\
\hline U.S. Total $\ldots \ldots \ldots \ldots \ldots \ldots \ldots \ldots$ & 23.4 & 10.7 & 14.2 & 23.6 & 12.9 \\
\hline
\end{tabular}

$--=$ Not applicable.

Note: One mill $=0.1$ cent.

Source: Energy Information Administration, Coal Transportation Rate Data Base.

\section{Regional Profiles}

This section describes contract coal profiles for each of the four demand regions and three supply regions, covering the years 1979, 1986, and 1993. These profiles include the principal regions supplying or demanding the contract coal, the prevalent transportation modes, the average transportation rate per ton, and the average transportation rate per ton-mile. Significant changes in these factors that occurred between 1979 and 1993 are also discussed.

\section{Demand Regions}

\section{Northeast}

Electric utilities in the Northeast received all of their contract coal from Appalachia. From 30 million tons in 1979, their demand fell to 24 million tons in 1986, and then rebounded to 32 million tons in 1993. In 1993, about half of the coal was shipped by rail (up from 35 percent in 1979) and one-fourth was delivered by barge (down from 29 percent).
In 1993, the contract coal was shipped an average of 278 miles, compared with 213 miles in 1979 and 295 miles in 1986, reflecting changes in the average distance of rail shipments. The average transportation rate fell from $\$ 9.40$ per ton in 1979 to $\$ 8.18$ per ton in 1993 , as rail rates declined. Because coal prices fell faster than transportation costs, the transportation component of the average delivered price rose from 20 percent in 1979 to 26 percent in 1993. The transportation rate per tonmile fell by 36 percent between 1979 and 1993.

\section{Midwest}

More contract coal is shipped to the Midwest than to any other demand region. Being centrally located between the Appalachian, Interior, and Western coalfields, Midwestern utilities received substantial quantities of contract coal from each of the three major coal supply regions. However, between 1986 and 1993, Midwestern utilities made a pronounced switch from Interior Region coals to Western coals. In 1993, 55 percent of their contract coal was shipped from the Western Region, compared with 36 percent in 1986. There were no significant changes in transportation mode over the 
1979 through 1993 period. About 60 percent of the coal was shipped by rail, followed by multimodal shipments (14 percent of the total) and barge movements (11 percent).

From 508 miles in 1979, the average shipping distance fell to 444 miles in 1986. It then increased to 675 miles in 1993, as more coal was shipped to Midwestern utilities from the Western Region by rail and long multimodal (rail/barge) movements. Partly because of the longer shipping distances, as well as increased competition and productivity gains in the railroad industry, the average transportation rate per ton-mile fell by 48 percent between 1986 and 1993. As a result, despite the increase in the distance the coal was shipped, the average transportation cost fell from $\$ 8.08$ per ton in 1986 to $\$ 7.41$ per ton in 1993. Transportation cost represented 33 percent of the average delivered price in 1993, compared with 22 percent in 1986, because coal prices fell faster than transportation rates.

\section{South}

Contract coal shipments to electric utilities in the South increased by 29 million tons between 1979 and 1993, more than to any other region. In 1979, utilities in the South obtained 73 percent of their contract coal from Appalachia. By 1986, that percentage had fallen to 62 percent, as more coal was obtained from the Interior and Western supply regions. Between 1986 and 1993, utilities switched from Interior Region to Western coal supplies. By 1993, the Western Region supplied 29 percent of the contract coal shipped to utilities in the South, compared with 12 percent in 1979. Railroads were the principal transporters of contract coal to the region throughout the 1979 through 1993 period, moving 71 percent of the coal shipped in 1993. An additional 13 percent was transported by barge.

As utilities in the South received increasing amounts of Western coal, the average shipping distance for contract coal shipments to the region rose from 472 miles in 1979 to 660 miles in 1993. Partly because of the increase in shipping distance, the average transportation rate per ton-mile fell by 38 percent between 1979 and 1993. Most of this decline occurred between 1986 and 1993, and it brought the average cost of transporting contract coal to the South down from $\$ 12.76$ per ton in 1986 to $\$ 9.50$ per ton in 1993. In 1993, transportation cost represented 31 percent of the average delivered price of the contract coal shipped to utilities in the South. This proportion was about the same as in 1986, but substantially higher than in 1979, when minemouth coal prices were higher.

\section{West}

In percentage terms, the greatest growth in contract coal deliveries occurred in the West, where receipts increased by 45 percent between 1979 and 1993. All of the contract coal received by utilities in the West came from mines in the Western supply region. In 1993, 46 percent of the contract coal shipped to power plants in the West was moved by conveyor, tramway, and coal slurry pipeline. Primarily, these were conveyor movements at minemouth power plants. Another 31 percent of the total was shipped by rail, and 24 percent was hauled by truck.

Because of the concentration of minemouth power plants in the region, the average distance of contract coal shipments to utilities in the West is lower than for any other region. The average shipping distance increased between 1979 and 1993, primarily because of longer rail hauls, and the average transportation rate per ton-mile fell slightly. The average transportation rate per ton was virtually the same in 1993 as in 1979, but transportation cost represented 27 percent of the average delivered price, up from 24 percent in 1979, because of falling minemouth coal prices.

\section{Supply Regions}

\section{Appalachia}

Contract coal shipments from Appalachia increased from 151 million tons in 1979 to 178 million tons in 1986, but fell back to 156 million tons in 1993, as less Appalachian coal was delivered to utilities in the South. Even in 1993, however, 52 percent of the Appalachian contract coal was shipped to utilities in the South. Utilities in the Midwest and the Northeast received 28 percent and 20 percent of the total, respectively. Railroads transported half of the contract coal shipped from Appalachia in 1993, and about one-fifth was moved by barges.

Between 1979 and 1993, the average shipping distance for the contract coal from Appalachia rose by 25 percent, to 324 miles. The average shipping distance increased for all transportation modes. The average transportation rate per ton-mile fell by 36 percent over the same period. Therefore, despite the increased shipping distance, the average cost of transporting the contract coal from Appalachia fell from $\$ 8.56$ per ton in 1979 to $\$ 6.91$ per ton in 1993 . As minemouth coal prices fell faster than transportation rates, the transportation component of the average delivered price increased from 17 percent in 1979 to 21 percent in 1993. 


\section{Interior Region}

Between 1979 and 1986, contract coal shipments from the Interior Region to electric utilities in the South more than doubled, reaching 34 million tons. Shipments to utilities in the Midwest remained about the same, at about 60 million tons. Then, between 1986 and 1993, dramatic changes occurred, as shipments from the Interior Region to the South and the Midwest fell by 63 percent and 39 percent, respectively. Basically, this decline was the result of the fall in the demand for the region's high-sulfur coal. However, the coal miners' strikes and severe floods of 1993 also reduced the amount of coal shipped from the region in that year. As was the case for Appalachian coal, railroads were the principal transporters of contract coal from the Interior Region (hauling 56 percent of the total in 1993), followed by barges.

Because of the reduced shipments to utilities in the South, the average shipping distance for the contract coal from the Interior Region fell from 232 miles in 1986 to 174 miles in 1993. The average transportation rate per ton-mile fell by 36 percent over the same period, due to substantial declines in barge and truck rates and the increased proportion of the coal shipped by barge. Primarily because of the fall in average shipping distance, the cost of transporting the contract coal from the Interior Region fell from $\$ 5.32$ per ton in 1979 to $\$ 3.07$ per ton in 1993. In 1993, largely due to the short average shipping distance, transportation cost represented only 12 percent of the average delivered price, compared with 14 percent in 1979.

\section{Western Region}

While contract coal shipments from the Interior Region declined between 1979 and 1993, and shipments from
Appalachia grew modestly, shipments from the Western Region increased by 71 percent. In particular, shipments from the Western Region to electric utilities in the South more than tripled. Shipments to utilities in the Midwest also increased substantially. In 1993, 212 million tons of contract coal were shipped from the Western Region, making it the largest source of contract coal. All of the major coal transportation modes were used extensively to deliver this coal.

Throughout the period in question, the average shipping distance for the contract coal from the Western Region was much longer than for coal from the other supply regions, and it increased from 769 miles in 1979 to 871 miles in 1993 . Partly because of the long shipping distance, the average transportation rate per tonmile was quite low, and it decreased by 41 percent between 1979 and 1993. Over the same period, the average cost of shipping the contract coal from the Western Region fell by 36 percent, from $\$ 15.24$ to $\$ 9.76$ per ton. Because of the relatively long average shipping distance, this cost was substantially higher than for coal from Appalachia and the Interior Region. In 1993, transportation cost represented 51 percent of the average delivered price for the contract coal shipped from the Western Region. This proportion was about the same as it was in 1979, and it was much higher than the transportation cost component for coal from the other supply regions. 
Appendix A

Detailed Description of the Coal Transportation Rate Data Base 
. 


\section{Appendix A}

\section{Detailed Description of the Coal Transportation Rate Data Base}

Appendix A presents a detailed description of the Coal Transportation Rate Data Base (CTRDB), including its content and data sources, data reliability, data quality, relationship to other data systems and coverage, and data availability.

\section{History and Database Description}

The CTRDB is a comprehensive database that contains electric utility coal supply contract data and transportation-related data. The data for this system are originally collected by Federal Energy Regulatory Commission (FERC) on Form 580, "Interrogatory on Fuel and Energy Purchase Practices," to conduct reviews of utility fuel and energy purchase practices as mandated by the Public Utility Regulatory Policies Act of 1978 (Public Law 95-617), which amended Section 205 of the Federal Power Act of 1920. The survey is conducted every 2 years. It requires responses from all jurisdictional utilities that either operate at least one steamelectric generating station with a capacity of 50 megawatts or greater or have an ownership interest in a jointly-owned steam-electric station with a capacity of 50 megawatts or greater. Jurisdictional utilities are investor-owned utilities that sell electric power at wholesale to other utilities.

The CTRDB was originally developed to provide information on coal supply contracts, contract tonnage, contract expiration date, and transportation rate by mode for the Energy Information Administration (EIA) model used to project coal supply and transportation. Starting in 1985, coal contract information for 1983 was obtained from FERC. In 1986, all contract and transportation information was collected from the FERC 580 survey responses for the years 1984 and 1985. In 1987, a need for an historical analysis of transportation rates arose. At that point, FERC provided EIA with historical coal contract information from the FERC Form 580 for the years 1979 through 1982.
The CTRDB currently contains data for 1979 through 1993 and is updated as new data are collected in the FERC Form 580 survey. The system contains approximately 858 records for each year and represents about 135 investor-owned utilities. Investor-owned electric utilities may be independently operated or part of a holding company. The utilities are usually operating companies that provide basic services for the generation, transmission, and distribution of electricity. Investor-owned electric utilities currently operate in all States except Nebraska.

The FERC is not required to collect data from federally owned electric utilities, publicly owned utilities, municipalities, cooperatives, or nonjurisdictional utilities. The Tennessee Valley Authority (TVA), the largest federally owned power producer, with coal receipts of 40 million tons in 1993 and electric utility plants operating in Alabama, Kentucky, and Tennessee, is not required to report on the FERC 580. Texas Utilities Electric Co., a large nonjurisdictional utility that is not required to report on the FERC 580, had coal receipts of 31.5 million tons in 1993. Publicly owned utilities not reporting on the FERC 580 are concentrated in Arizona, California, Nebraska, Oregon, and Washington.

Because FERC Form 580 and thus the CTRDB excludes a significant portion (32 percent in 1993) of the contract coal consumed at and transported to U.S. electric utilities, an effort was made to improve the coverage of the CTRDB and to provide a more comprehensive view of transportation rates. The CTRDB was expanded to include aggregated rail revenue rates for the years 1988 through 1993 obtained from the Interstate Commerce Commission for regions not covered by FERC Form 580. The CTRDB was augmented by the inclusion of aggregated confidential data from FERC Form 580 and with derived transportation rates that were computed from known mine price and delivered price data. 
The records contained within the CTRDB are contractand route-oriented. For each utility plant receiving coal under a specific contract, the CTRDB provides an origin-to-destination record for every route over which that plant's coal flows. A contract record within the CTRDB can be broken down into four subsets of data fields: contract accounting and specification information, plant information, route information, and transportation mode information. A utility company within the database can have several coal supply contracts; one coal supply contract can serve several plants; an individual plant can receive coal from several mines on the same contract; and an individual plant can be covered by several different contracts.

The contract accounting and specification information consist of:

- Contract code

- Utility company code

- Utility name

- Contract sign data

- Contract expiration data

- Contract modification date

- Annual base tonnage contracted

- Btu contracted

- Sulfur content contracted

- Ash content contracted

- Moisture content contracted

- Contract/supplier name

- Mine name

- Origin State code

- Origin State name

- Origin county code

- Bureau of Mines district code

- Type of contract.

The plant-related data consist of:

- Plant code

- Plant name

- Plant location by State code and name

- Actual volume of coal shipped to the plant during year under survey

- Minemouth price of coal shipped to plant

- Delivered price of coal shipped to plant

- Btu content of actual coal shipments

- Actual sulfur content of shipments

- Actual ash content of shipments

- Actual moisture content of shipments

- Number of boilers targeted by the Clean Air Act.

Route and transportation mode related data consist of:

- Route number
- Number of links

- Total line-haul distance for the route

- Transportation mode for each route link

- Line-haul distance for each link

- Transportation rate for each link

- Transfer fees for route transshipment points

- Transshipment point name

- Railroad or barge company name.

Coal prices and transportation rate data may be reported in cents per million Btu, dollars per ton, and dollars per million Btu. Coal shipments and base contracted tons are in short tons. Sulfur and ash contents are in percent by weight. Heat content is reported in Btu per pound.

\section{Relationship to Other Data Systems and Coverage}

Since the CTRDB is drawn from the FERC Form 580 system survey, its data consistency and coverage can be described in the context of the FERC Form 580 and its relationship to other data systems. The FERC Form 580 survey population is a subpopulation within the survey population for FERC Form 423, "Monthly Report of Cost and Quality of Fuels for Electric Utilities." The FERC Form 580 covers jurisdictional utilities while FERC Form 423 covers all utilities, i.e., investor-owned utilities, federally owned utilities, municipalities, and cooperatives. The FERC Form 580 survey is conducted every 2 years, while the FERC Form 423 survey is conducted monthly. Furthermore, FERC Form 580 covers an average of 135 utilities and 259 plants per year, while FERC Form 423 covered approximately 235 utilities and 700 power plants in 1993. In addition, FERC Form 580 collects data for utility contract purchases only, whereas FERC Form 423 collects data for both utility contract purchases and spot purchases. Spot purchases are purchase orders to obtain coal for a period of less than 1 year.

Although both surveys collect data on utility contract purchases of coal, more utilities report contract purchases on the FERC Form 423 than on the FERC Form 580 , and thus, the coverage and the contract tonnage reported is higher than for the FERC Form 580. Contract tonnage was chosen as the variable to measure consistency of reporting for the two systems. Table A1 gives a comparison of the total contract tonnage for the FERC Form 580 utilities and plants as a percent of the FERC Form 423 total contract tonnage. The FERC Form 580 utilities and plants accounted for 68 to 75 percent of FERC Form 423 utility contract tonnage from 1979 to 1993. 
Table A1. Comparison of FERC Form $\mathbf{5 8 0}$ Contract Coal Tonnage and FERC Form 423 Contract Coal Tonnage, 1979-1993 (Million Short Tons)

\begin{tabular}{c|c|c|c}
\hline Year & $\begin{array}{c}\text { FERC } \\
\text { Form 423 }\end{array}$ & $\begin{array}{c}\text { FERC } \\
\text { Form 580 }\end{array}$ & Percent $^{\text {a }}$ \\
\hline $1979 \ldots \ldots$ & 485.1 & 353.7 & 72.9 \\
$1980 \ldots \ldots$ & 525.6 & 383.1 & 72.9 \\
$1981 \ldots \ldots$ & 503.4 & 355.4 & 70.6 \\
$1982 \ldots \ldots$ & 543.8 & 380.0 & 69.9 \\
$1983 \ldots \ldots$ & 523.6 & 381.6 & 72.9 \\
$1984 \ldots \ldots$ & 584.8 & 440.6 & 75.3 \\
$1985 \ldots \ldots$ & 592.4 & 438.7 & 74.1 \\
$1986 \ldots \ldots$ & 601.0 & 423.0 & 70.4 \\
$1987 \ldots \ldots$ & 610.2 & 421.7 & 69.1 \\
$1988 \ldots \ldots$ & 627.8 & 436.1 & 69.5 \\
$1989 \ldots \ldots$ & 620.9 & 433.6 & 69.8 \\
$1990 \ldots \ldots$ & 648.6 & 446.4 & 68.8 \\
$1991 \ldots \ldots$ & 655.5 & 457.7 & 69.8 \\
$1992 \ldots \ldots$ & 649.5 & 440.9 & 67.9 \\
$1993 \ldots \ldots$ & 616.0 & 418.0 & 67.9 \\
\hline
\end{tabular}

${ }^{\text {a}}$ FERC Form 580 tonnage as a percent of FERC Form 423 total contract tonnage.

Source: Federal Energy Regulatory Commission, FERC Form 580, "Interrogatory on Fuel and Energy Purchase Practices," and FERC Form 423, "Monthly Report of Cost and Quality of Fuels for Electric Utilities."

The total coal received at U.S. utilities, including tonnage from contract and spot purchases, amounted to 769.2 million tons in 1993, according to FERC Form 423. The 418.1 million tons of contract tonnage reported on the FERC Form 580 in 1993 was 54 percent of the FERC Form 423 coal receipts or total tonnage. The contract tonnage for the utilities missing from the FERC Form 580 survey along with the FERC Form 423 spot coal tonnage is shown in Table A2.

Survey population differences contribute to four sources of variations between the two systems' data series: (1) frame differences; (2) different reporting periods; (3) requirements based on electric generating station capacity (steam-electric generating station and peaking units with either 24 megawatts capacity or 50 megawatts capacity could have reported on either survey, depending on the requirements at the time); and (4) data reporting procedures, data recording, and processing procedures for the two systems.
Table A2. FERC Form 423 Contract and Spot Coal Tonnage Not Covered by FERC Form 580, 1979-1993 (Million Short Tons)

\begin{tabular}{cc|r|r}
\hline Year & Contract & Spot & Total \\
\hline $1979 \ldots \ldots$ & 121.6 & 69.6 & 191.2 \\
$1980 \ldots \ldots$ & 121.4 & 66.3 & 187.7 \\
$1981 \ldots \ldots \ldots$ & 119.7 & 74.4 & 194.1 \\
$1982 \ldots \ldots \ldots$ & 140.3 & 56.3 & 196.6 \\
$1983 \ldots \ldots$ & 142.0 & 66.0 & 208.0 \\
$1984 \ldots \ldots$ & 145.0 & 96.7 & 241.8 \\
$1985 \ldots \ldots$ & 158.3 & 71.8 & 230.1 \\
$1986 \ldots \ldots$ & 168.6 & 83.4 & 252.0 \\
$1987 \ldots \ldots$ & 179.5 & 108.4 & 287.9 \\
$1988 \ldots \ldots$ & 159.0 & 97.1 & 256.1 \\
$1989 \ldots \ldots$ & 166.6 & 128.9 & 295.5 \\
$1990 \ldots \ldots$ & 166.7 & 132.7 & 299.4 \\
$1991 \ldots \ldots$ & 171.0 & 109.7 & 280.7 \\
$1992 \ldots \ldots$ & 189.9 & 119.7 & 309.6 \\
$1993 \ldots \ldots$ & 189.1 & 146.3 & 335.4 \\
\hline
\end{tabular}

Source: Federal Energy Regulatory Commission, FERC Form 580, "Interrogatory on Fuel and Energy Purchase Practices," and FERC Form 423, "Monthly Report of Cost and Quality of Fuels for Electric Utilities."

\section{Data Reliability and Quality}

The FERC manages all quality control issues, mandates the type of data collected, and handeles nonresponses and respondent contact records for the FERC Form 580.

Quality assurance measures in the extraction of data from the FERC Form 580 responses are handled by the EIA. An effort is made to rectify coding errors, tabulation errors, keying errors, and problems of data interpretation. However, FERC 580 responses may contain estimates or averages of transportation rates for several shipments under one contract and estimates of volumes and distances of shipments, because the data are not collected primarily for input into the CTRDB.

The data are coded onto hard copy coding forms as reported by the respondents. The coded forms are then compared with the original responses to detect and correct transcription errors. Once a computer file has been created, the computer file is compared with the coded forms to detect and correct data entry errors. 
An error detection and correction program is used to detect and correct errors that escape manual screening. This program consists of a set of ranges and range checks for all quantitative data fields within the database. The range values were established in coordination with FERC personnel. When the database is evaluated using this program, values that fall outside of pre-established ranges are identified for investigation. Internal inconsistencies are corrected using a program that compares values from year to year to detect outliers based on the series of values. This program also resolved problems of record redundancy. Table presentations are also examined for regional and national transportation data consistencies. Data record printouts are reviewed and outliers are eliminated where deemed necessary.

For a few specific demand regions, supply regions, and/or transportation modes, time series data vary considerably from one year to the next. In most cases, this appears to be due to the small number of records for which transportation rate data were available for that particular region or transportation mode. In those cases, fluctuations in tonnage or rates for one contract could have a substantial influence on the regional average. This situation occurred most frequently for shipments from the "Other Western Interior" region and for shipments by truck and "other" transportation modes (primarily conveyors). Although the averages based on this "thin" data are included in the tables of this report, they were not used for any of the analyses upon which the report's conclusions are based.

\section{Data Availability}

The CTRDB data are based on public use data from the FERC 580 for the years 1979 through 1987 and both public use and confidential data for 1988 through 1993. For the years 1979 through 1987, data that were not available due to confidentiality consisted of coal transportation rate and coal minemouth price. Also, some records did not have complete data. To minimize the influence of missing data on statistical calculations, records with missing data were excluded from certain calculations. Furthermore, an effort was made to increase the availability of data through derivation in two ways: (1) When two of the three cost data elements were available, the third one was derived from the available data; i.e., if minemouth price and delivered price were available, the transportation rate was derived by subtracting the minemouth price from the delivered price; (2) certain FERC 580 confidential data were made available for the years 1988 through 1993 under an agreement between EIA and the FERC to use the confidential data only in an aggregated form.

The availability of data on coal transportation rate per ton, distance, and tonnage is important because these variables are used in the calculation of the average distance shipped, average transportation rate per ton, and average transportation rate per ton-mile. Tables $\mathrm{A3}$, $\mathrm{A} 4$, and $\mathrm{A} 5$ show the number of records omitted from the calculation of average distance shipped, average rate per ton, and average rate per ton-mile.

Table A3 shows the number of records omitted, along with the corresponding tonnage, in the calculation of average distance shipped shown in Table 34 of the report. The table also shows the number of records used and the corresponding tonnage. The last column of Table A3 shows that the proportion of tonnage represented by the average distance ranges from about 80 percent in 1979 to almost 88 percent in 1990 and 1991.

Table A4 shows similar data for the calculation of average rate per ton shown in Table 35 of the report. Of particular note is the decreasing proportion of tonnage represented in the tonnage calculations between 1979 and 1987, particularly in 1986 and 1987. An increase in tonnage represented in calculating the average transportation rate per ton was achieved for all years from 1979 through 1987 by deriving the rate from the two available data elements, minemouth price and delivered price, and adding confidential data for the years 1988 through 1993.

Table A5 shows how many records with rate data elements were available and how much tonnage was excluded in the calculation of average transportation rates per ton-mile shown in Table 37 of the report. Because the calculation of rate per ton-mile requires both distance and rate data elements, the tonnage represented in calculation of average rate per ton-mile is affected more than other calculations by missing data elements. The tonnage represented in the calculation of rate per ton-mile increased slightly due to the derived transportation rates for the period 1979 through 1987. 
Table A3. Data Elements Available for the Calculation of Average Distance Shipped, 1979-1993

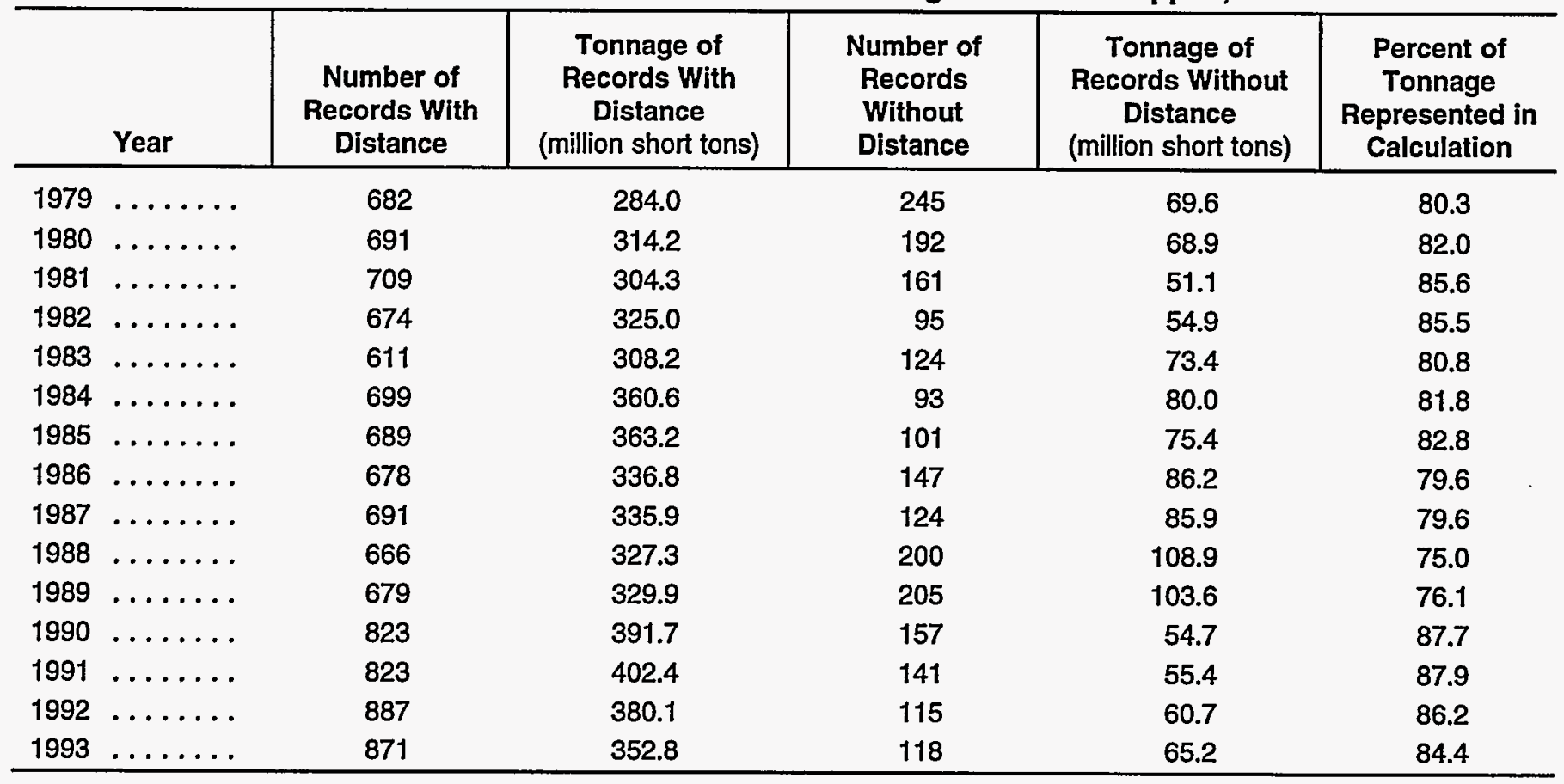

Source: Federal Energy Regulatory Commission, FERC Form 580, "Interrogatory on Fuel and Energy Purchase Practices."

Table A4. Data Elements Available for the Calculation of Average Transportation Rate per Ton, 1979-1993

\begin{tabular}{|c|c|c|c|c|c|c|}
\hline & Year & $\begin{array}{c}\text { Number of } \\
\text { Records } \\
\text { With Rate } \\
\end{array}$ & $\begin{array}{c}\text { Tonnage of } \\
\text { Records } \\
\text { With Rate } \\
\text { (million short tons) }\end{array}$ & $\begin{array}{c}\text { Number of } \\
\text { Records } \\
\text { Without Rate }\end{array}$ & $\begin{array}{c}\text { Tonnage of } \\
\text { Records } \\
\text { Without Rate } \\
\text { (million short tons) } \\
\end{array}$ & $\begin{array}{l}\text { Percent of } \\
\text { Tonnage } \\
\text { Represented in } \\
\text { Calculation } \\
\end{array}$ \\
\hline 1979 & $\ldots \ldots$ & 780 & 281.0 & 147 & 72.6 & 79.5 \\
\hline 1980 & $\ldots \ldots$ & 763 & 312.8 & 120 & 70.4 & 81.6 \\
\hline 1981 & $\ldots \ldots \ldots$ & 752 & 291.0 & 118 & 64.4 & 81.9 \\
\hline 1982 & $\ldots \ldots$ & 612 & 288.4 & 157 & 91.6 & 75.9 \\
\hline 1983 & $\ldots \ldots \ldots$ & 565 & 288.9 & 170 & 92.7 & 75.7 \\
\hline 1984 & $\ldots \ldots$ & 614 & 315.4 & 178 & 125.2 & 71.6 \\
\hline 1985 & $\ldots \ldots$ & 618 & 310.2 & 172 & 128.5 & 70.7 \\
\hline 1986 & $\ldots \ldots$ & 469 & 201.7 & 356 & 221.3 & 47.7 \\
\hline 1987 & $\ldots \ldots \ldots$ & 465 & 203.5 & 350 & 218.3 & 48.2 \\
\hline 1988 & $\ldots \ldots$ & 667 & 297.2 & 199 & 139.0 & 68.1 \\
\hline 1989 & $\ldots \ldots \ldots$ & 685 & 297.2 & 199 & 136.4 & 68.5 \\
\hline 1990 & $\ldots \ldots \ldots$ & 788 & 352.0 & 192 & 94.4 & 78.8 \\
\hline 1991 & $\ldots \ldots$ & 774 & 359.5 & 190 & 98.2 & 78.5 \\
\hline 1992 & $\ldots \ldots$ & 899 & 355.9 & 103 & 84.9 & 80.7 \\
\hline 1993 & $\ldots \ldots \ldots$ & 890 & 337.2 & 99 & 80.9 & 80.7 \\
\hline
\end{tabular}

Source: Federal Energy Regulatory Commission, FERC Form 580, "Interrogatory on Fuel and Energy Purchase Practices." 
Table A5. Data Elements Available for the Calculation of Average Transportation Rate per Ton-Mile, 1979-1993

\begin{tabular}{cc|c|c|c|c|c}
\hline & $\begin{array}{c}\text { Number of } \\
\text { Records } \\
\text { With Rate }\end{array}$ & $\begin{array}{c}\text { Tonnage of } \\
\text { Records } \\
\text { With Rate } \\
\text { (million short tons) }\end{array}$ & $\begin{array}{c}\text { Number of } \\
\text { Records } \\
\text { Without Rate }\end{array}$ & $\begin{array}{c}\text { Tonnage of } \\
\text { Records } \\
\text { Without Rate } \\
\text { (million short tons) }\end{array}$ & $\begin{array}{c}\text { Percent of } \\
\text { Tonnage } \\
\text { Represented in } \\
\text { Calculation }\end{array}$ \\
\hline $1979 \ldots \ldots \ldots$ & 626 & 257.6 & 301 & 96.1 & 72.8 \\
$1980 \ldots \ldots \ldots$ & 614 & 291.2 & 269 & 91.9 & 76.0 \\
$1981 \ldots \ldots \ldots$ & 632 & 277.7 & 238 & 77.7 & 78.1 \\
$1982 \ldots \ldots \ldots$ & 539 & 282.2 & 230 & 97.8 & 74.3 \\
$1983 \ldots \ldots \ldots$ & 491 & 259.6 & 244 & 122.1 & 68.0 \\
$1984 \ldots \ldots \ldots$ & 494 & 306.1 & 298 & 134.6 & 69.5 \\
$1985 \ldots \ldots \ldots$ & 572 & 305.4 & 218 & 133.3 & 69.6 \\
$1986 \ldots \ldots \ldots$ & 418 & 190.0 & 407 & 233.0 & 44.9 \\
$1987 \ldots \ldots \ldots$ & 421 & 192.6 & 394 & 229.2 & 45.7 \\
$1988 \ldots \ldots \ldots$ & 580 & 277.9 & 286 & 158.3 & 63.7 \\
$1989 \ldots \ldots \ldots$ & 594 & 280.4 & 290 & 153.1 & 64.7 \\
$1990 \ldots \ldots \ldots$ & 702 & 337.7 & 278 & 108.7 & 75.7 \\
$1991 \ldots \ldots \ldots$ & 694 & 344.9 & 270 & 112.8 & 75.3 \\
$1992 \ldots \ldots \ldots$ & 815 & 338.2 & 187 & 102.6 & 76.7 \\
$1993 \ldots \ldots \ldots$ & 803 & 320.4 & 186 & 97.6 & 76.7 \\
\hline
\end{tabular}

aissing data could be rate or distance or both. The corresponding tonnage is automatically excluded from the calculation when records are dropped from consideration.

Source: Federal Energy Regulatory Commission, FERC Form 580, "Interrogatory on Fuel and Energy Purchase Practices." 
Appendix B

Characteristics of Coal Supply Contracts Reported on the FERC Form $\mathbf{5 8 0}$ 


\section{Appendix B}

\section{Characteristics of Coal Supply Contracts Reported on the FERC Form $\mathbf{5 8 0}$}

Appendix B presents background information on the characteristics of coal supply contracts as they are reported on the Federal Energy Regulatory Commission (FERC) Form 580, "Interrogatory on Fuel and Energy Purchase Practices." Table B1 presents detailed information on individual coal supply contracts effective in 1993, organized by contract expiration date, electric utility company, and power plant.

Coal supply contracts are binding agreements, usually lasting 1 year or longer, between utility companies and coal producers and/or brokers. Coal supply contracts contain provisions that are binding upon the utility company and the vendor for the duration of the contract agreement. Typically, such provisions address:

1. Term or length of contract, possibly with contract extension provisions

2. Minimum quantity to be purchased

3. Source(s) of the coal and/or its quality characteristics
4. Base rate in terms of dollars per ton as of the effective date of the contract

5. Rate adjustment, which is used to adjust rates for inflation or deflation. Rate adjustment may be annual or quarterly and may be partial or total. It may be based on various indices, such as the gross domestic product (GDP) implicit price deflator. Adjustment may be aggregate or component-by-component, and may include adjustment for productivity change.

Other items addressed by the contract agreement are price, base quantity, quality specifications, quality incentives, quality penalties, supplier name, fuel production location, contract sign date, expiration date, and renewal and renegotiation options.

Coal supply contract information, including transportation- and shipment-related data, is listed in Table B1 for each plant receiving coal under contract reported on the FERC 580. Table B1 contains contracts, effective in 1993, that are to expire in 1995 and beyond. The data for 1993 contracts that expired in 1993 and 1994 are not shown. 
Table B1. Utility Contract Coal Shipments in 1993 by Expiration Date

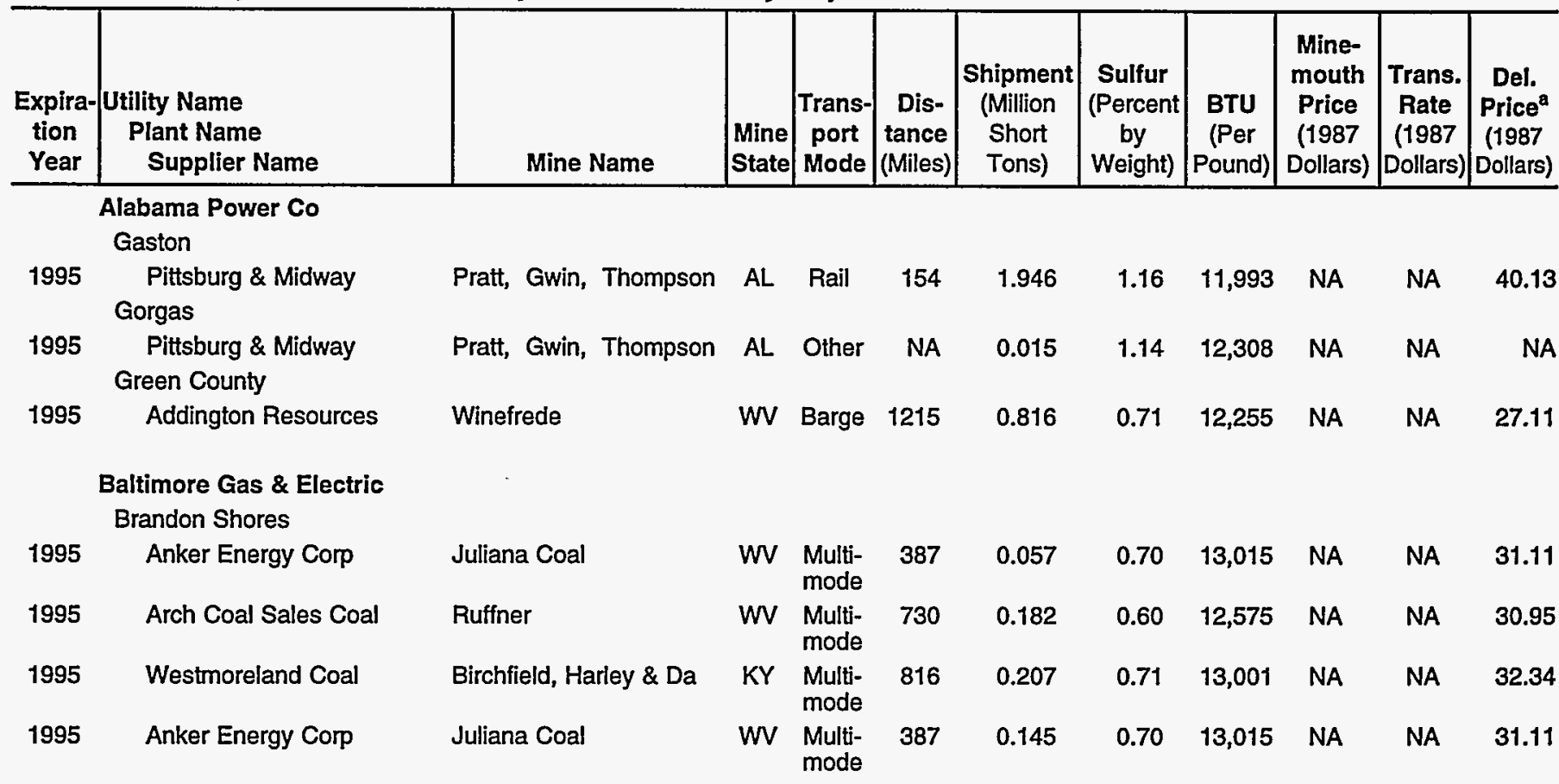

Cardinal Operating Co

Cardinal

1995

M.M. Coal Company

M.M. Coal Company

Various

OH Rail 23

0.126

$3.13 \quad 12,273 \quad N A$

NA $\quad 25.76$

Various

$\mathrm{OH}$ Truck 10

0.126

$3.1312,273$ NA NA

25.76

Central Illinois Light Co

Duck Creek

1995

Blue Diamond Coal Co

Leatherwood

KY Rail 760

0.009

$\begin{array}{llll}0.78 & 13,484 & \text { NA } & \text { NA }\end{array}$

39.15

E.D. Edwards

1995

Blue Diamond Coal Co

Leatherwood

KY Multi- 759

0.120

$0.7513,356 \quad N A \quad N A$

33.22

1995

Blue Diamond Coal Co

Leatherwood

KY Rail 727

0.120

$0.7513,356 \quad N A \quad N A$

33.22

Central Illinois Public

Service Co

Newton

1995

Atlas Minerals/Buck Indiana

IN Barg

66

0.084

0.5

$\begin{array}{lll}10,429 & 19.68 \quad 3.90\end{array}$

23.58

Cincinnati Gas \& Electric Co

Beckjord

\begin{tabular}{|c|c|c|c|c|c|c|c|c|c|c|c|}
\hline 1995 & Ashland Coal Inc & Various & KY & Barge & 135 & 1.195 & 0.96 & 11,776 & 33.92 & 1.47 & 35.40 \\
\hline 1995 & Ohio Valley & Pitt, Upper Freeport & $\mathrm{OH}$ & Other & NA & 0.018 & 4.23 & 12,434 & 18.85 & NA & 22.25 \\
\hline \multicolumn{12}{|c|}{ East Bend } \\
\hline 995 & $\begin{array}{l}\text { Ashland Coal Inc } \\
\text { iami Fort }\end{array}$ & Various & KY & Barge & 193 & 0.358 & 1.07 & 11,791 & 33.96 & 1.82 & 35.72 \\
\hline 1995 & Ashland Coal Inc & & KY & Barge & 173 & 0.222 & 0.73 & 12,090 & 27.43 & 1.77 & 29.10 \\
\hline
\end{tabular}

See notes at end of table. 
Table B1. Utility Contract Coal Shipment in 1993 by Expiration Date (Continued)

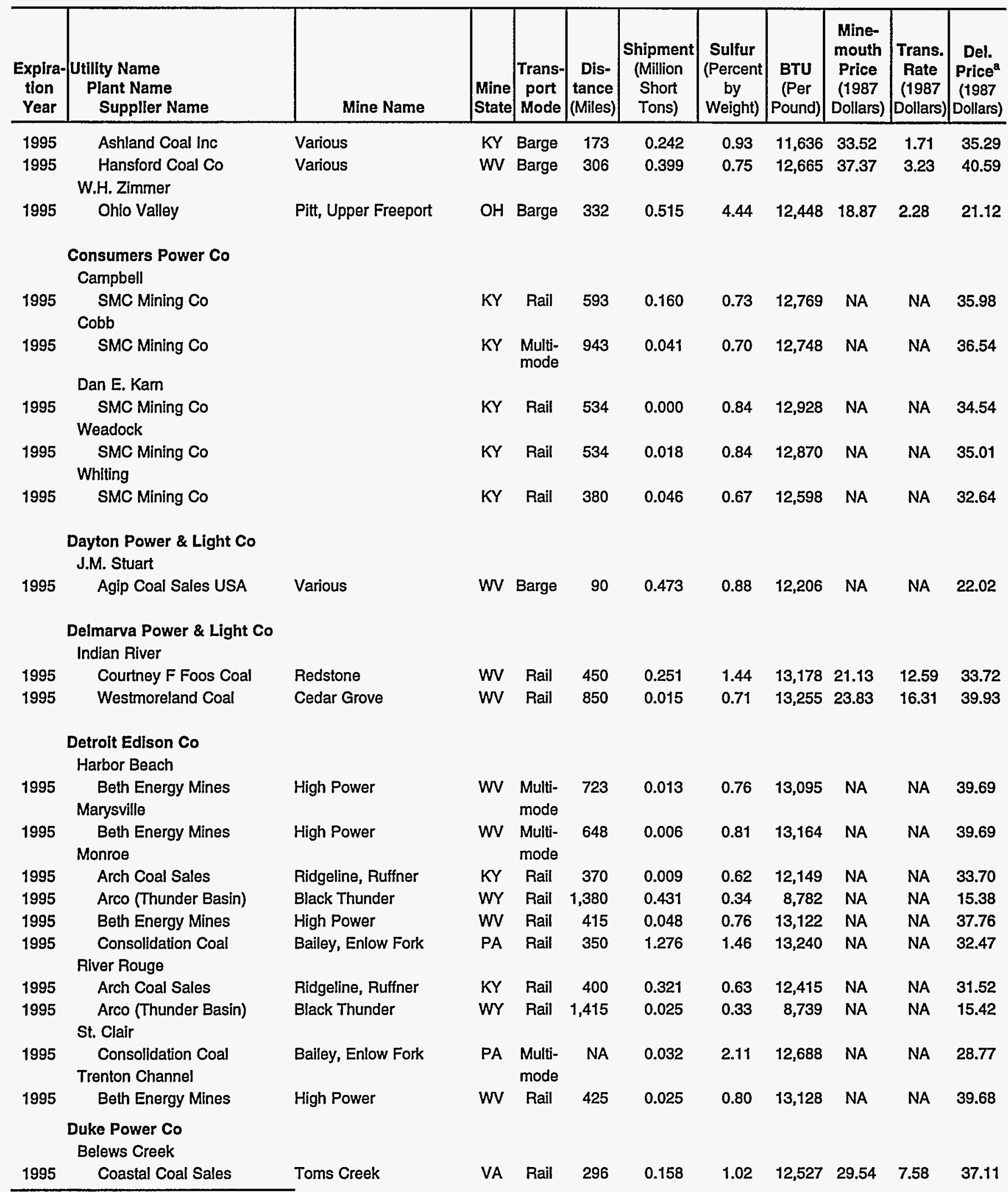

See notes at end of table. 
Table B1. Utility Contract Coal Shipment in 1993 by Expiration Date (Continued)

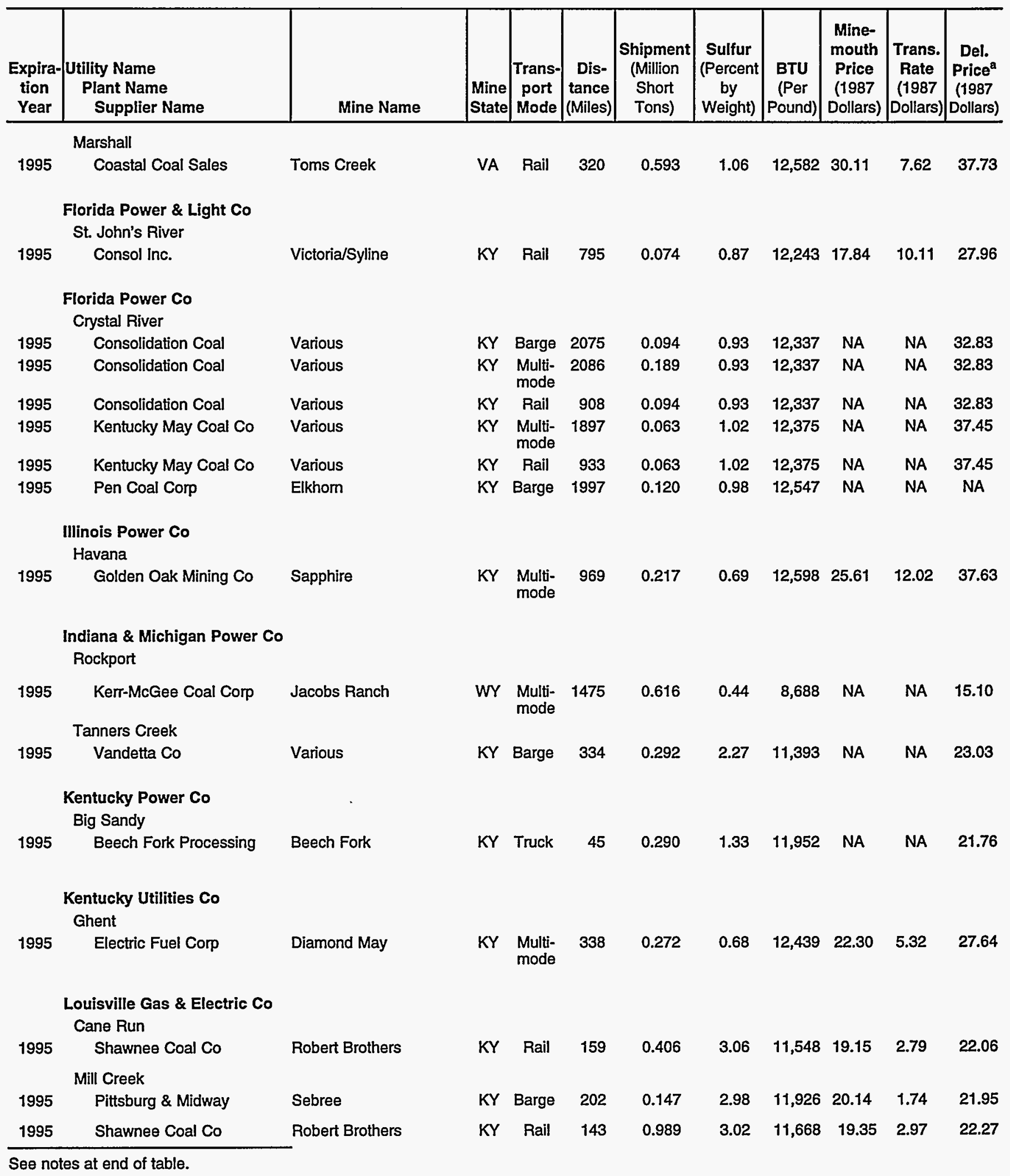


Table B1. Utility Contract Coal Shipment in 1993 by Expiration Date (Continued)

\begin{tabular}{|c|c|c|c|c|c|c|c|c|c|c|c|}
\hline \multicolumn{12}{|c|}{ Trimble County } \\
\hline 1995 & Pittsburg \& Midway & Sebree & KY & Barge & 257 & 0.173 & 3.02 & 12,068 & 20.38 & 1.81 & 22.14 \\
\hline \multicolumn{12}{|c|}{$\begin{array}{l}\text { Mississippi Power Co } \\
\text { Watson }\end{array}$} \\
\hline 1995 & Jader Fuel Co & Jader & IL & Barge & 1059 & 0.989 & 2.70 & 12,728 & NA & NA & 28.01 \\
\hline \multicolumn{12}{|c|}{$\begin{array}{l}\text { Missouri Public Service Co } \\
\text { Sibley }\end{array}$} \\
\hline \multicolumn{12}{|c|}{$\begin{array}{l}\text { Nevada Power Co } \\
\text { Reid Gardner }\end{array}$} \\
\hline 1995 & Soldier Creek Coal & Canyon & UT & Rail & 461 & 0.173 & 0.47 & 12,034 & 16.95 & 12.92 & 29.93 \\
\hline \multicolumn{12}{|c|}{$\begin{array}{l}\text { Northern States Power Co } \\
\text { Sherbume County }\end{array}$} \\
\hline 1995 & Thunder Basin Coal & Black Thunder & WY & Rail & 1100 & 2.198 & 0.34 & 8,775 & NA & NA & 19.04 \\
\hline 1995 & Westem Energy Co & & MT & Rail & 750 & 1.054 & 0.72 & 8,705 & NA & NA & 22.98 \\
\hline \multicolumn{12}{|c|}{$\begin{array}{l}\text { Ohio Power Co } \\
\text { Tidd }\end{array}$} \\
\hline \multicolumn{12}{|c|}{ Otter Tail Power Co } \\
\hline 1995 & Nerco Coal Corp & Spring Creek & MT & Rail & 833 & 0.282 & 0.31 & 9,235 & NA & NA & 18.25 \\
\hline \multicolumn{12}{|c|}{$\begin{array}{l}\text { Pennsylvania Electric Co } \\
\text { Conemaugh }\end{array}$} \\
\hline 1995 & Cooney Bros Coal Co & Cooney Bros & PA & Rail & 50 & 0.107 & 2.01 & 12,418 & NA & NA & 24.01 \\
\hline 1995 & Elton Coal Co & Various & PA & Rail & 50 & 0.303 & 2.19 & 12,380 & NA & NA & 23.97 \\
\hline 1995 & North Cambria Fuel & Indiana & PA & Rail & 28 & 0.300 & 2.13 & 12,456 & NA & NA & 24.11 \\
\hline 1995 & Summers Fuel Inc & Leslie & PA & Rail & 90 & 0.108 & 2.01 & 12,630 & NA & NA & 24.46 \\
\hline 1995 & United Eastern Coal & & PA & Rail & 28 & 0.207 & 2.12 & 12,403 & NA & NA & 23.84 \\
\hline \multicolumn{12}{|c|}{$\begin{array}{l}\text { Pennsylvania Power \& } \\
\text { Light Co }\end{array}$} \\
\hline \multicolumn{12}{|c|}{ Montour } \\
\hline 1995 & K \& J Coal Co & Various & PA & Rail & 194 & 0.239 & 2.02 & 12,504 & NA & NA & 29.54 \\
\hline
\end{tabular}


Table B1. Utility Contract Coal Shipment in 1993 by Expiration Date (Continued)

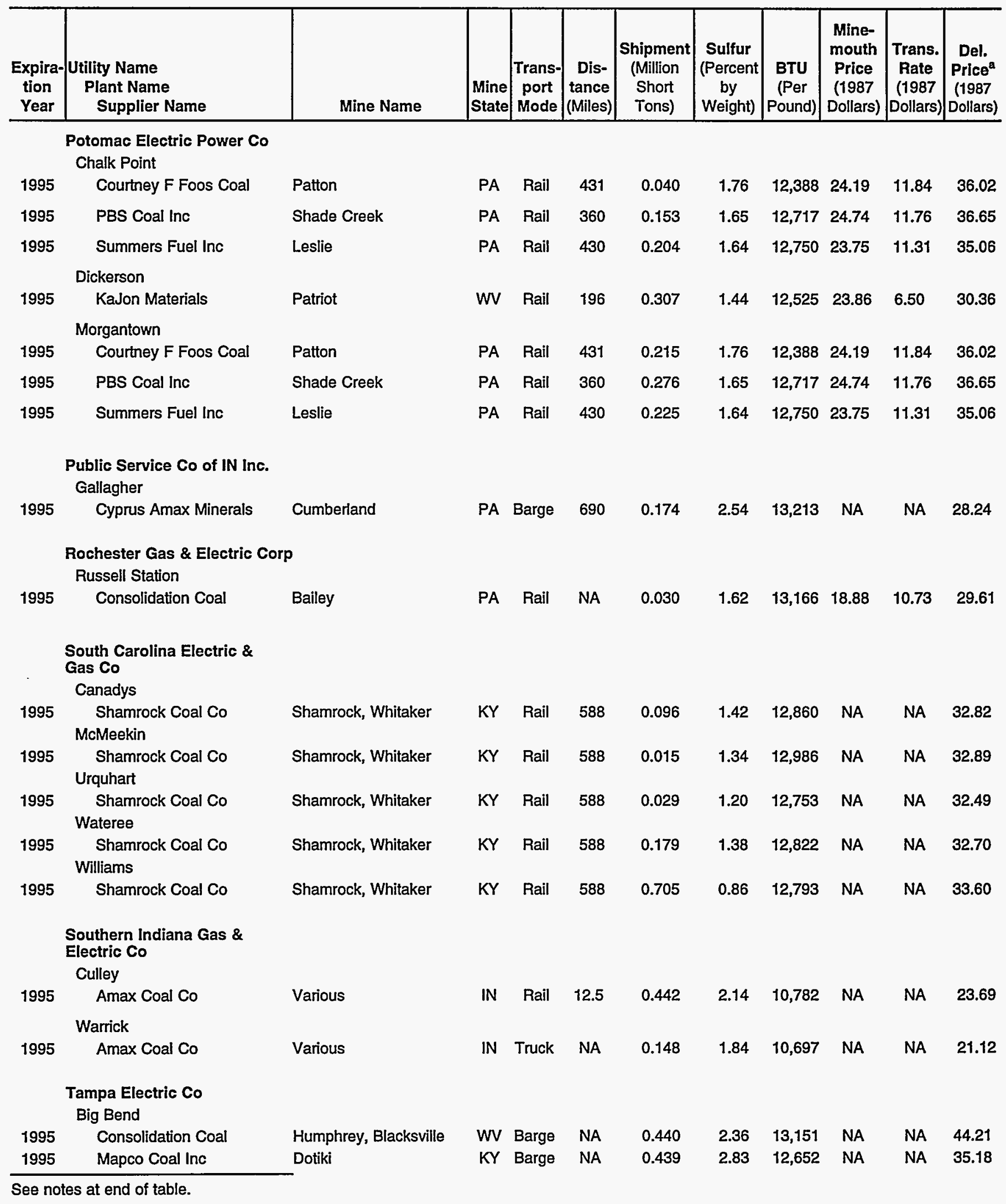


Table B1. Utility Contract Coal Shipment in 1993 by Expiration Date (Continued)

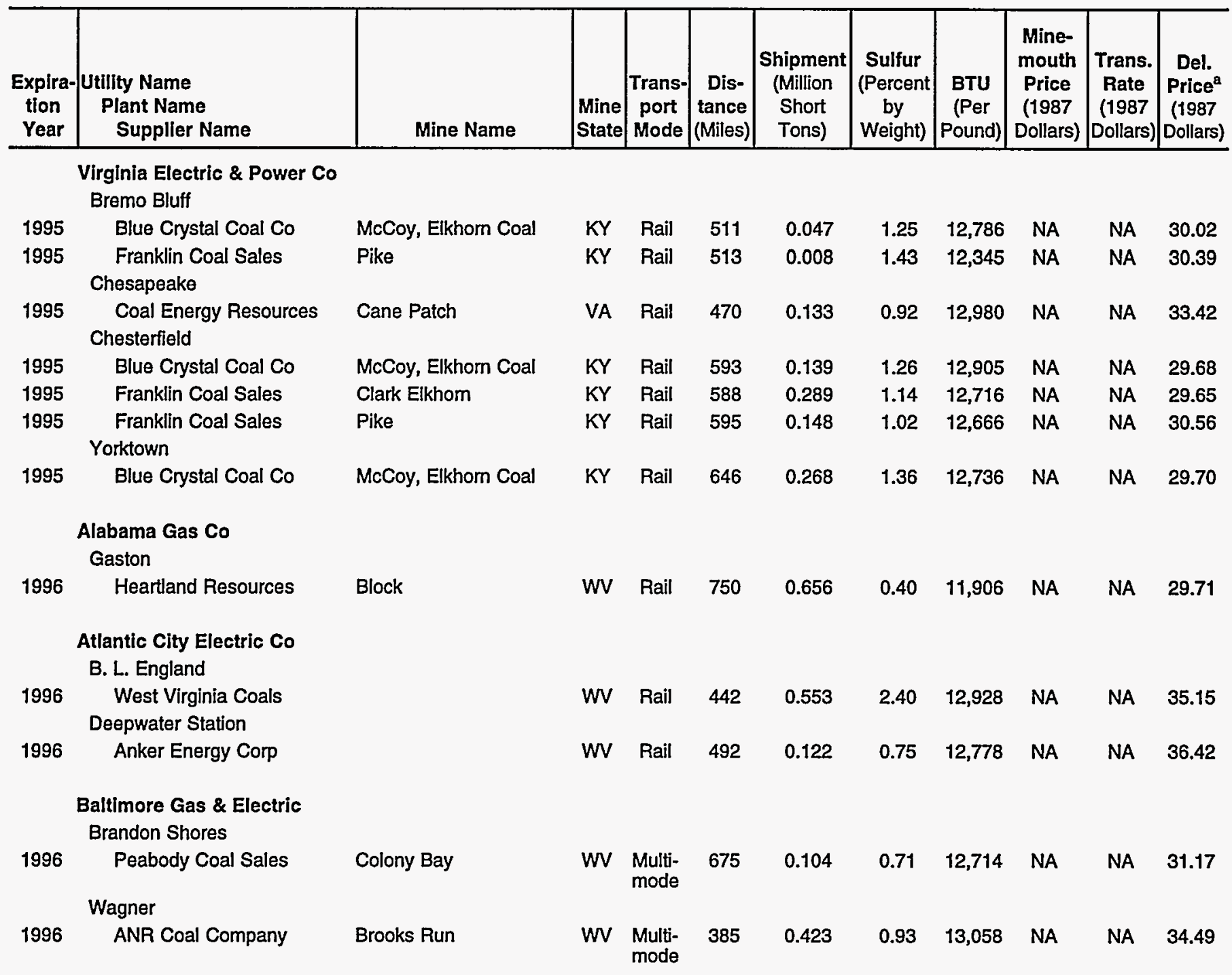

Carolina Power \& Light Co

Ashville

\begin{tabular}{|c|c|c|c|c|c|c|c|c|c|c|c|}
\hline 1996 & $\begin{array}{l}\text { Pyxis Coal Sales Co } \\
\text { Lee }\end{array}$ & Paramont & VA & Rail & 202 & 0.719 & 1.10 & 13,136 & NA & NA & 27.21 \\
\hline 1996 & $\begin{array}{l}\text { Agip Coal Inc } \\
\text { Mayo }\end{array}$ & Peuler & KY & Rail & 500 & 0.008 & 0.89 & 12,513 & NA & NA & 36.28 \\
\hline 1996 & $\begin{array}{l}\text { Agip Coal Inc } \\
\text { Roxboro }\end{array}$ & Peuler & KY & Rail & 328 & 0.131 & 0.67 & 12,749 & NA & NA & 34.18 \\
\hline 1996 & $\begin{array}{l}\text { Agip Coal Inc } \\
\text { Sutton }\end{array}$ & Peuler & $K Y$ & Rail & 328 & 0.856 & 1.07 & 12,305 & NA & NA & 33.23 \\
\hline 1996 & Agip Coal Inc & Peuler & $K Y$ & Rail & 544 & 0.009 & 0.85 & 12,077 & NA & NA & 36.39 \\
\hline
\end{tabular}

Central Hudson Gas \&

Electric Corp

Danskammer

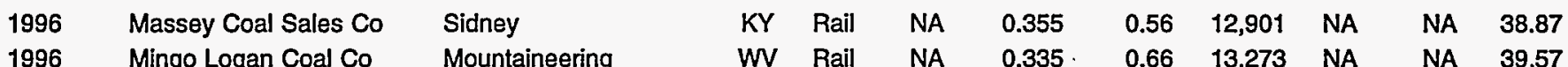

1996 Mingo Logan Coal Co

Mountaineering

WV Rail NA 0.335 .

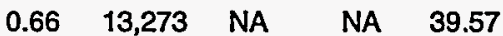

See notes at end of table. 
Table B1. Utility Contract Coal Shipment in 1993 by Expiration Date (Continued)

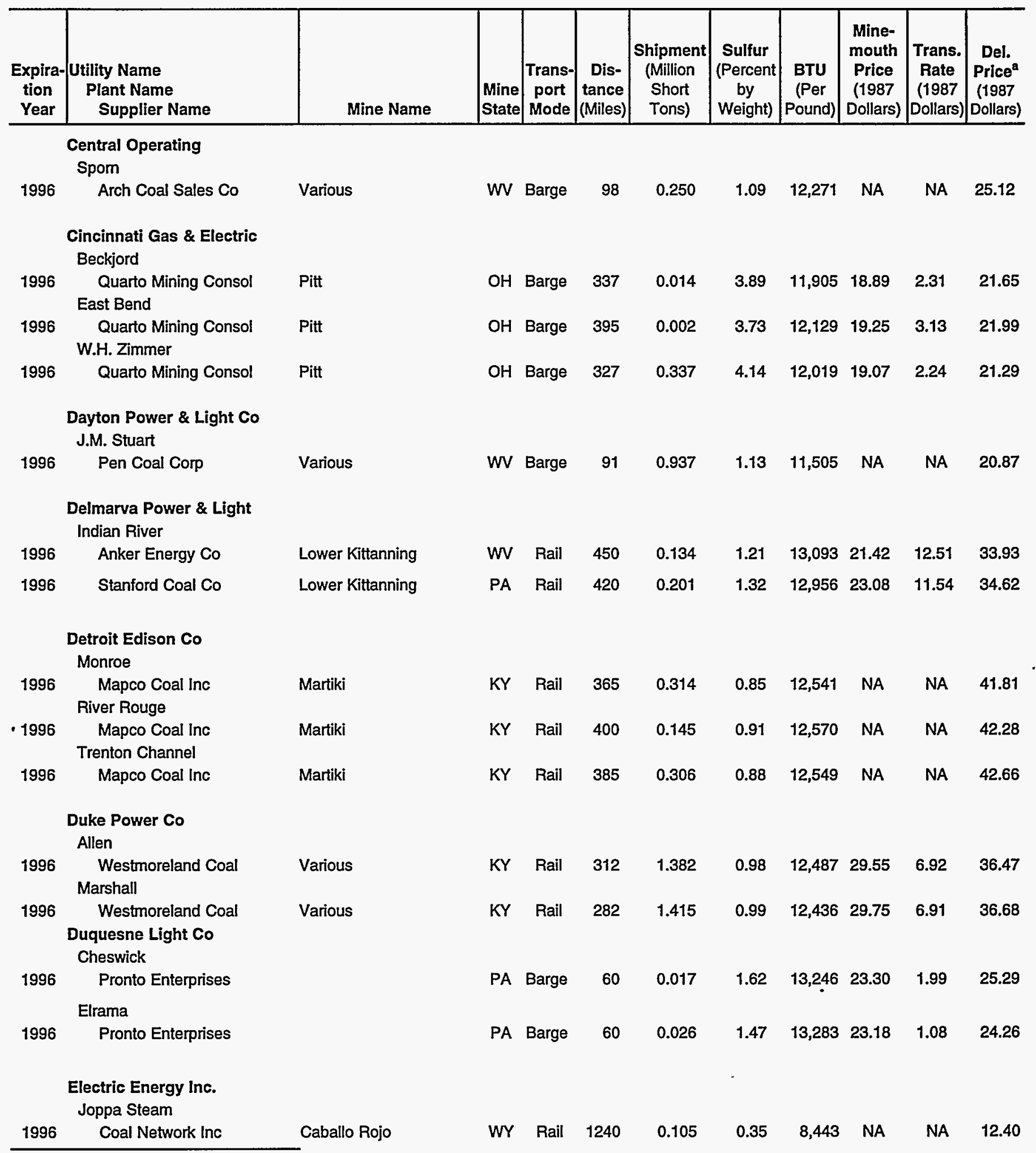

See notes at end of table. 
Table B1. Utility Contract Coal Shipment in 1993 by Expiration Date (Continued)

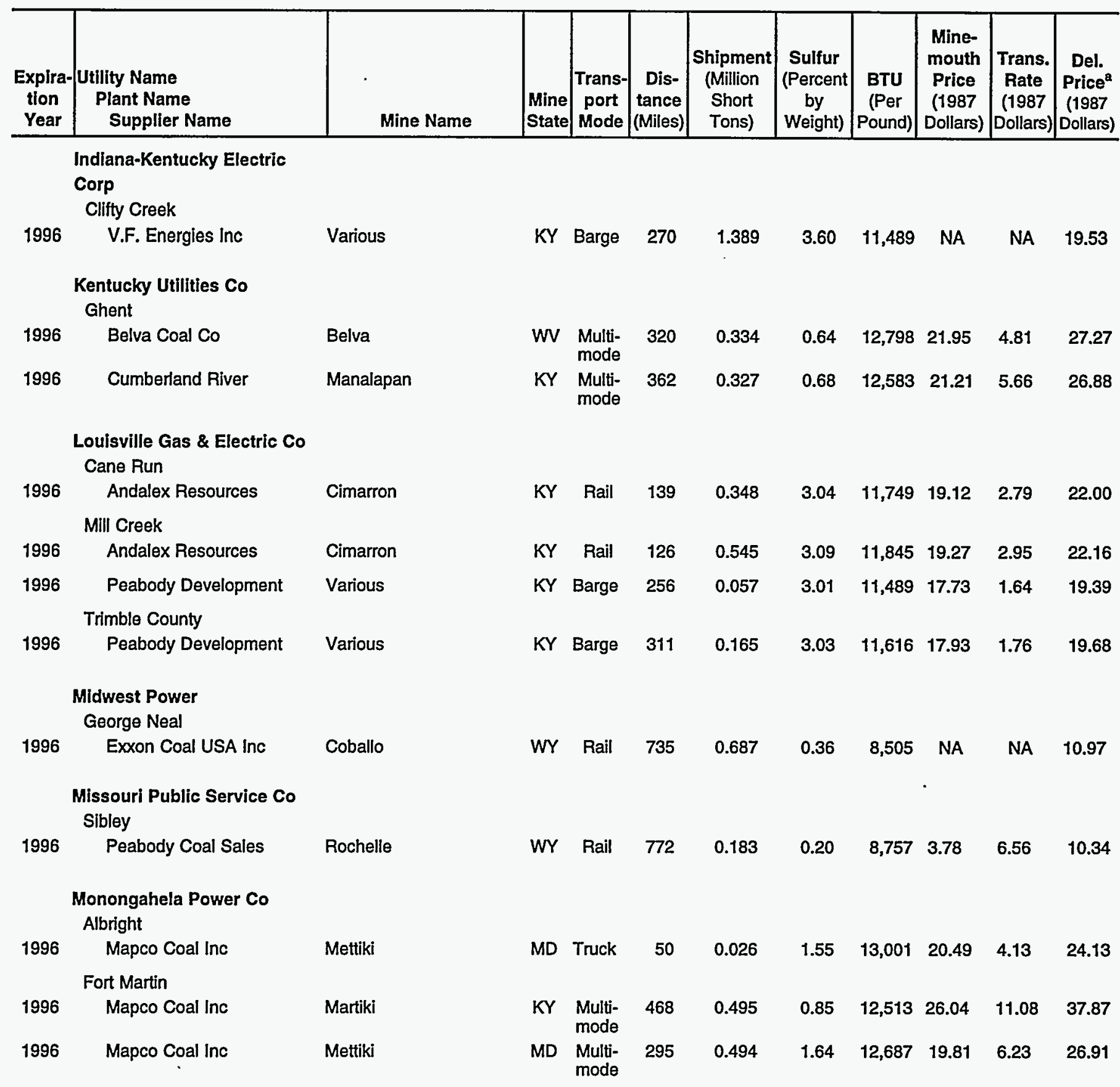

Public Service Co of

Colorado

Cameo

1996

Peabody Coal Sales

Cameo, Roadside

co Truck 0.5

0.243

$0.57 \quad 11,251 \quad$ NA

NA $\quad 16.47$

Public Service Co of

Indiana, Inc.

Wabash

1996 Little Sandy Coal Co

Pond Creek

IN Truck 40

0.020

$2.1411,090 \quad \mathrm{NA}$

NA

21.55 
Table B1. Utility Contract Coal Shipment in 1993 by Expiration Date (Continued)

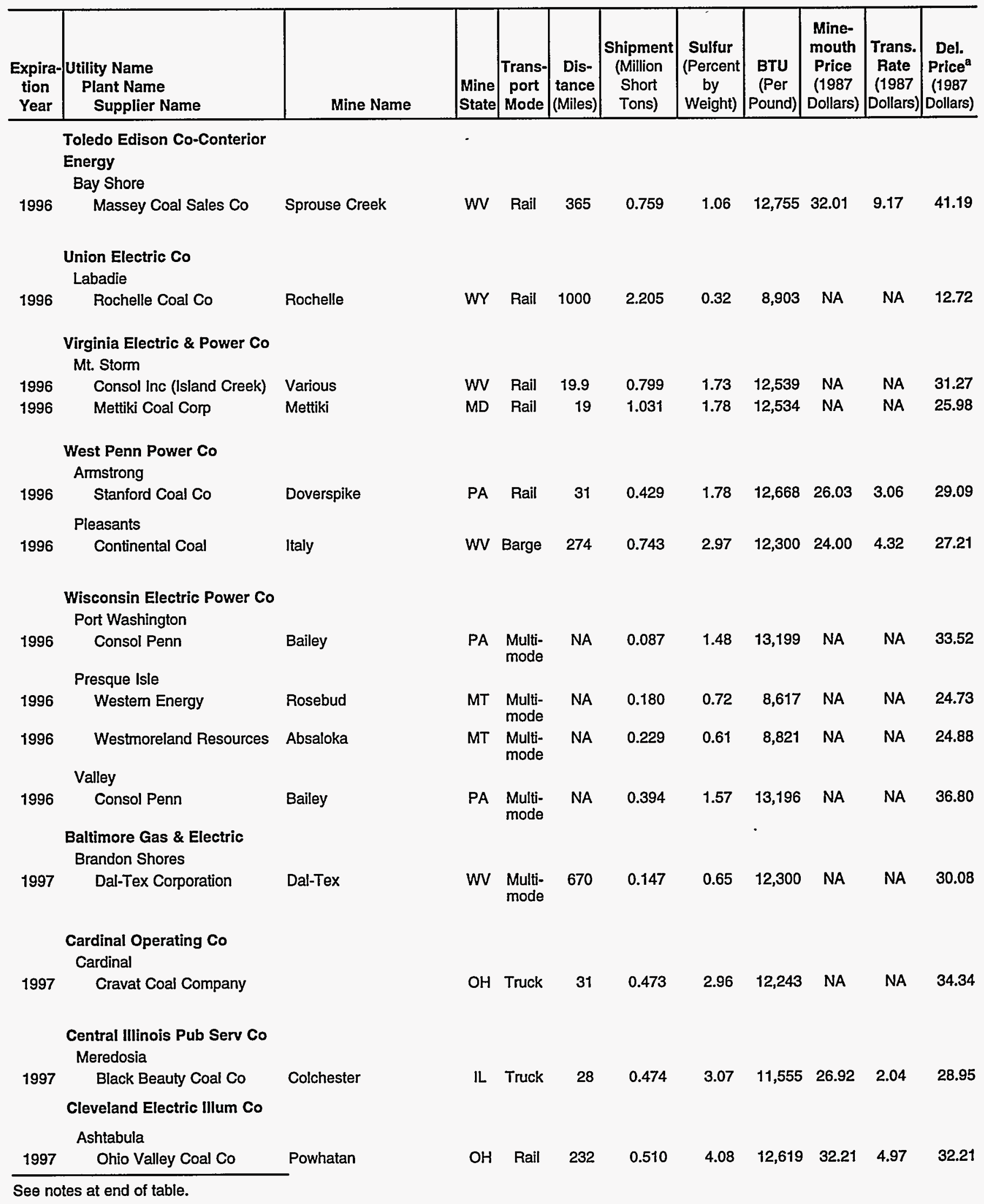


Table B1. Utility Contract Coal Shipment in 1993 by Expiration Date (Continued)

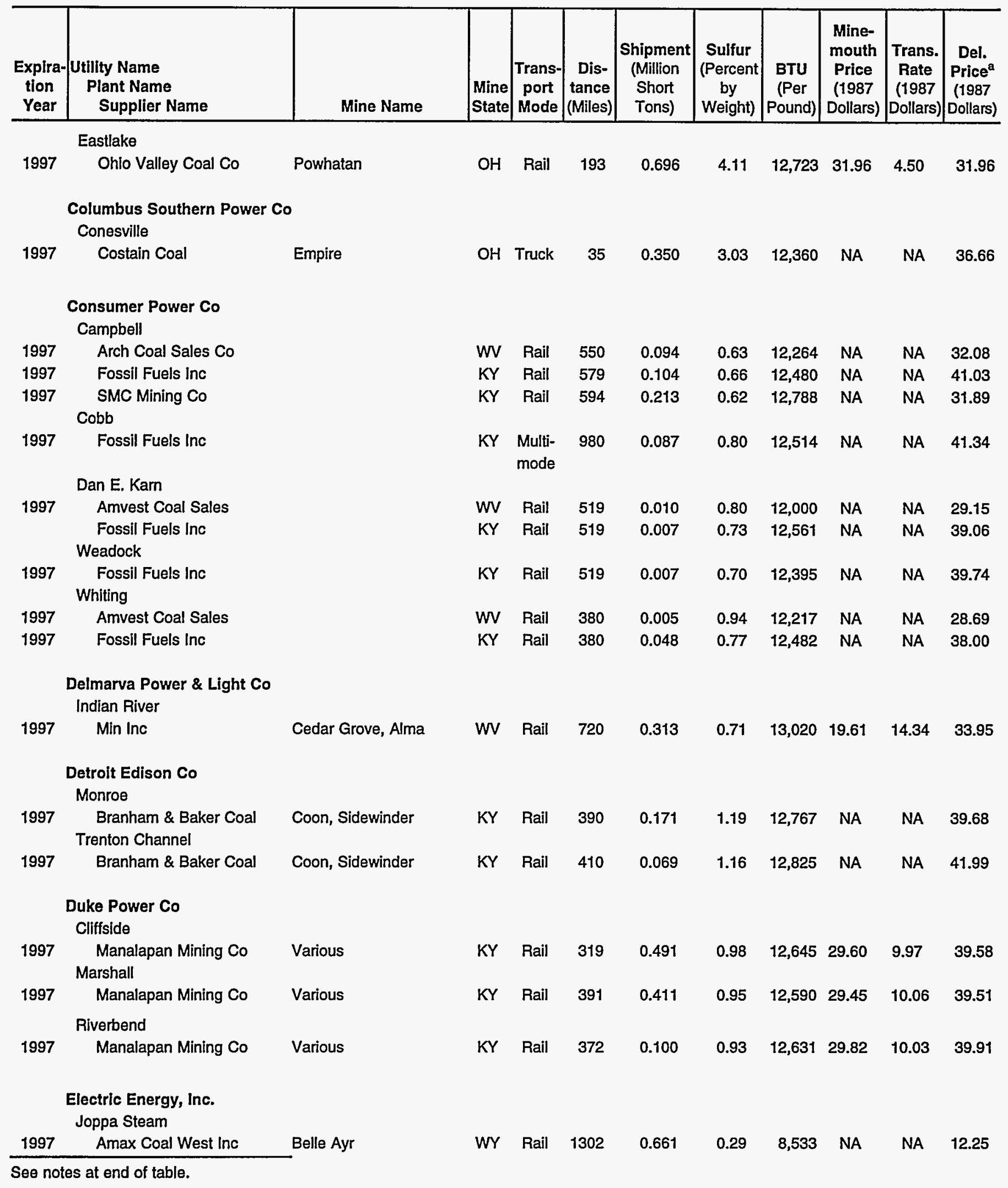


Table B1. Utility Contract Coal Shipment in 1993 by Expiration Date (Continued)

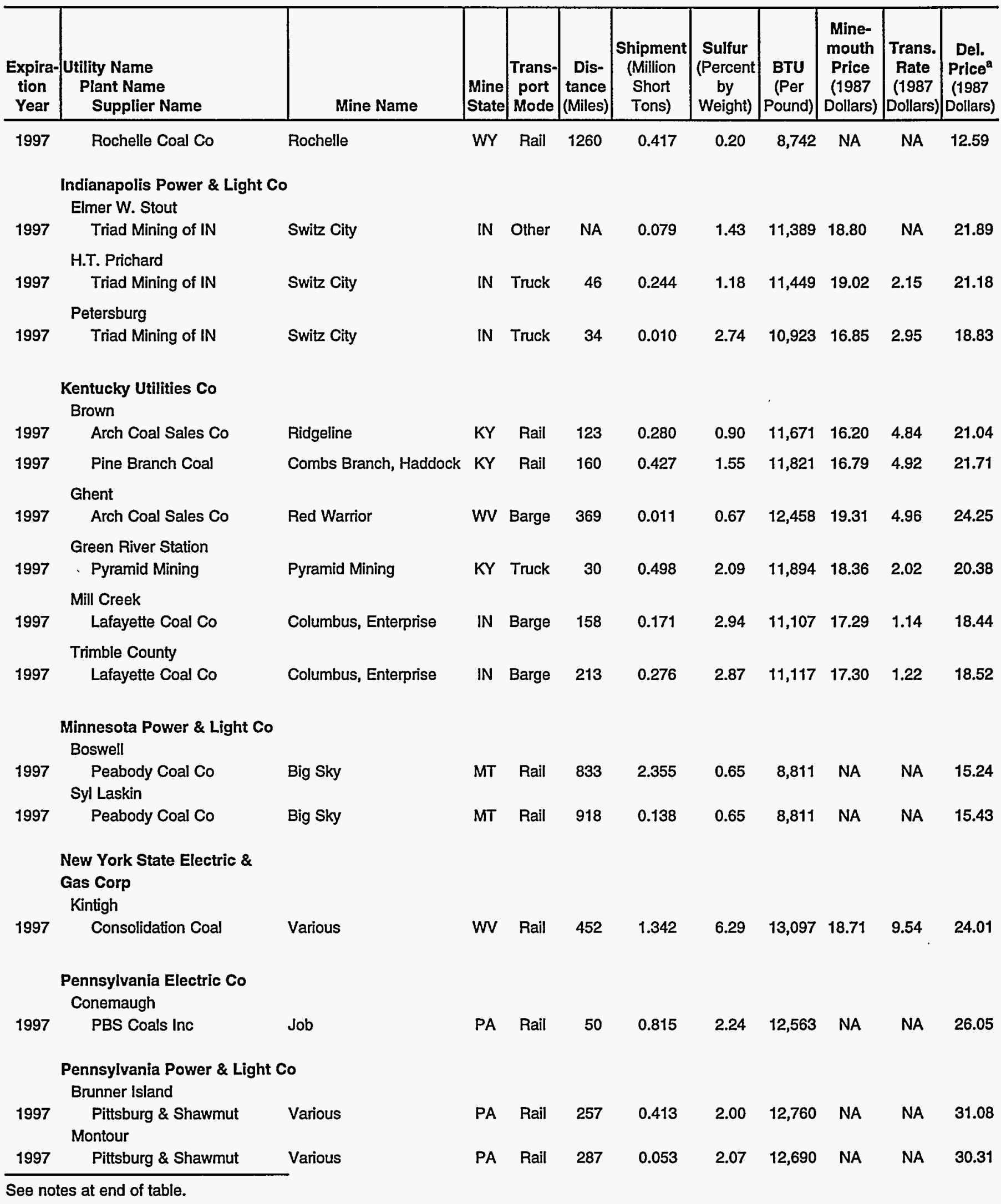


Table B1. Utility Contract Coal Shipment in 1993 by Expiration Date (Continued)

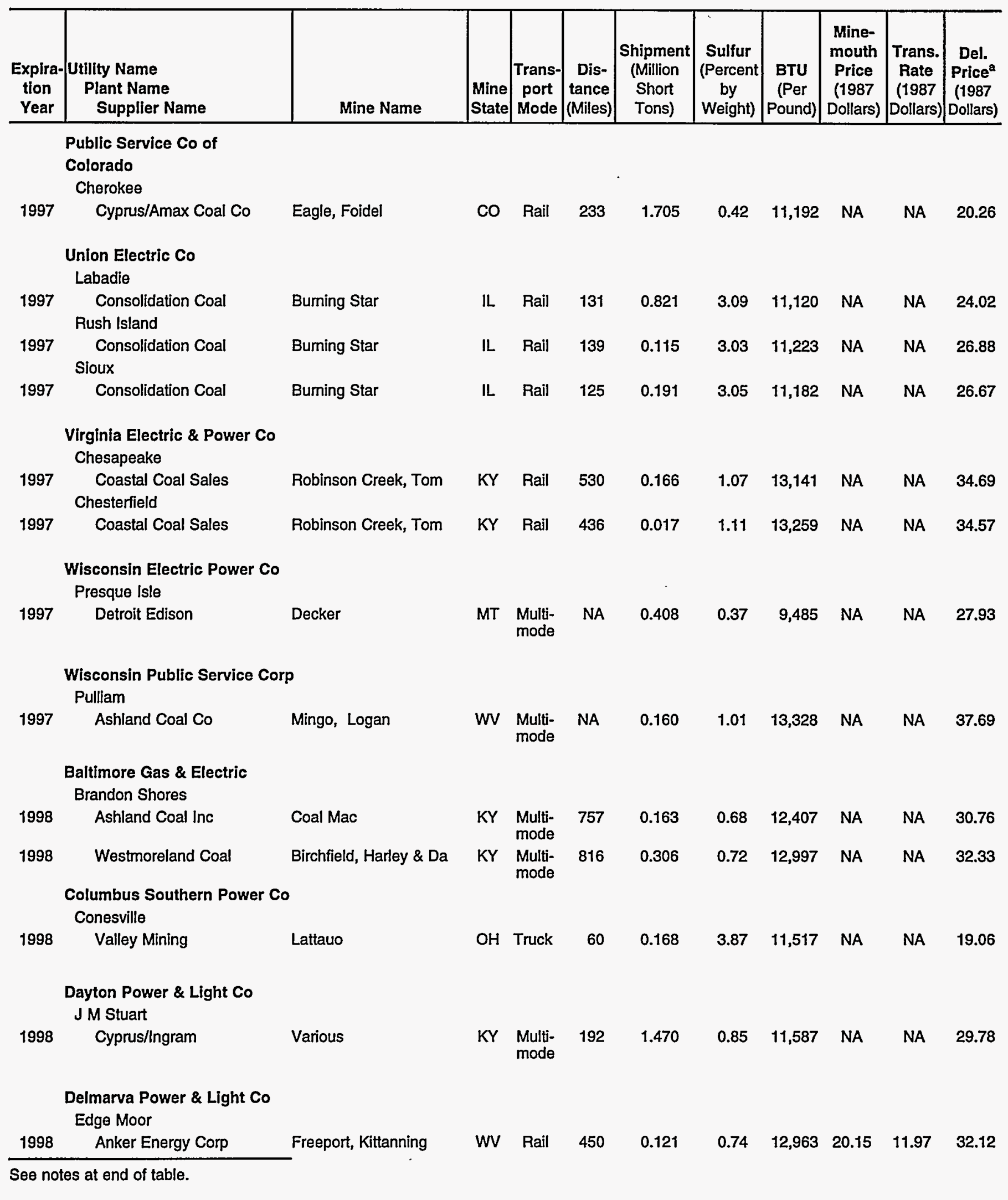


Table B1. Utility Contract Coal Shipment in 1993 by Expiration Date (Continued)

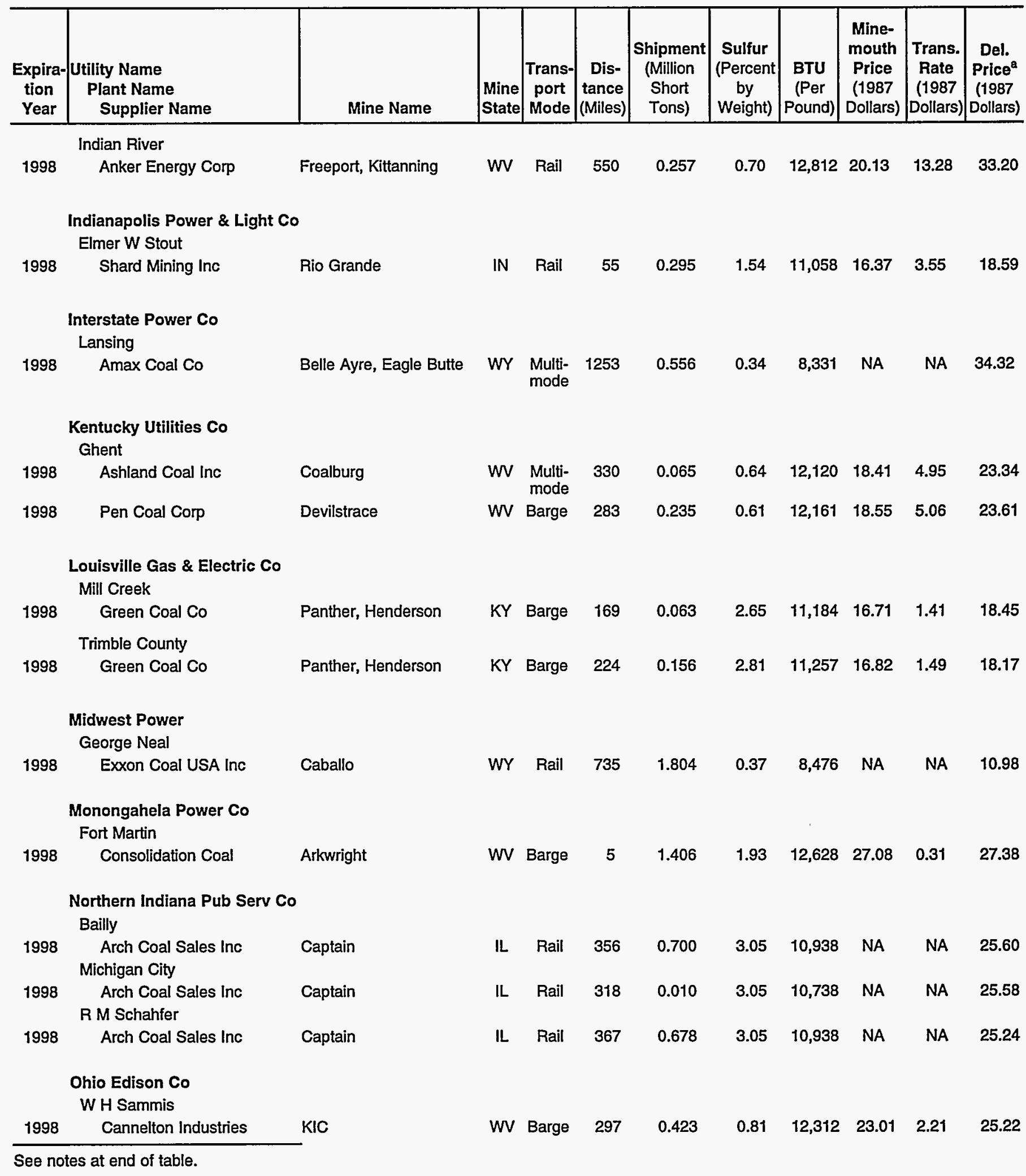


Table B1. Utility Contract Coal Shipment in 1993 by Expiration Date (Continued)

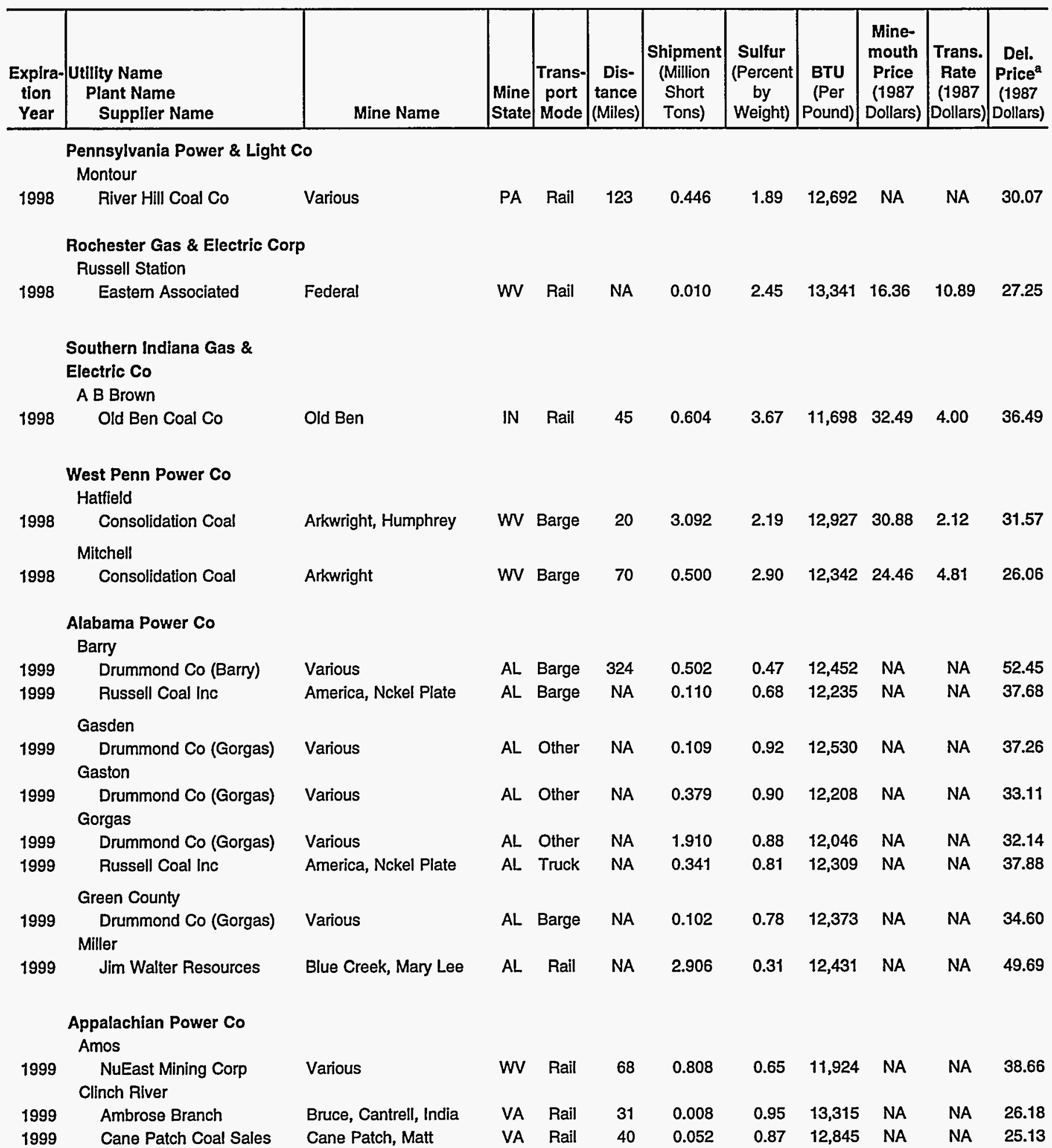

See notes at end of table. 
Table B1. Utility Contract Coal Shipment in 1993 by Expiration Date (Continued)

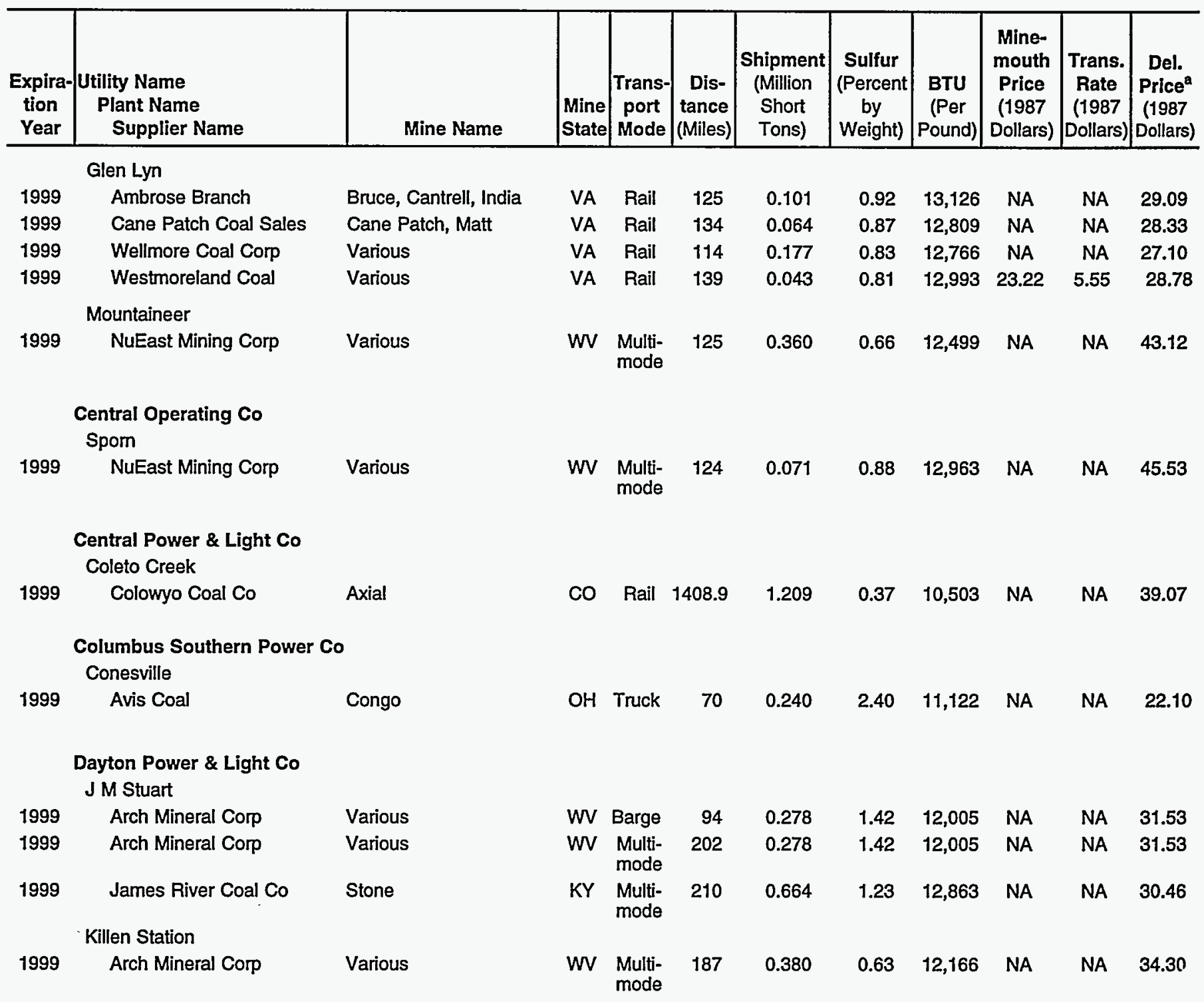

Electric Energy Inc.

Joppa Steam

1999 Arclar Coal Co

Big Ridge/llinois

0.214

$1.9712,363 \quad \mathrm{NA}$

NA 22.61

Florida Power Corp

Crystal River

1999 Golden Oak Mining Sapphire

KY Rail $930 \quad 1.444$

$0.70 \quad 12,992 \quad N A$

NA $\quad 36.30$

Illinois Power Co

Baldwin

1999 Arch Coal Sales

Various

IL $\quad$ Rail $\quad 25 \quad 1.764$

$2.96 \quad 10,919 \quad 20.94$

2.16

See notes at end of table. 
Table B1. Utility Contract Coal Shipment in 1993 by Expiration Date (Continued)

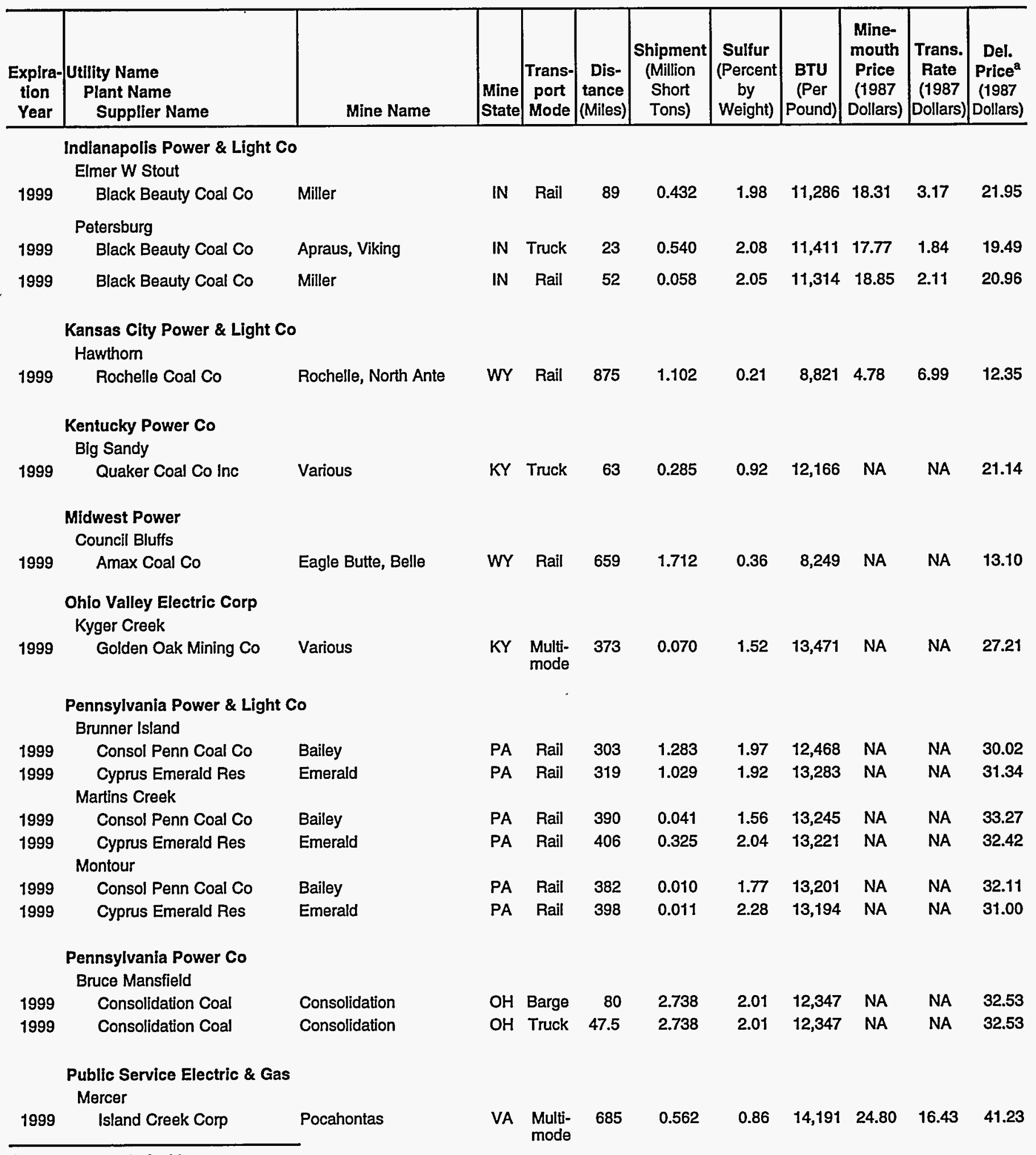

See notes at end of table. 
Table B1. Utility Contract Coal Shipment in 1993 by Expiration Date (Continued)

\begin{tabular}{|c|c|c|c|c|c|c|c|c|c|c|c|}
\hline $\begin{array}{c}\text { Expira- } \\
\text { tion } \\
\text { Year } \\
\end{array}$ & $\begin{array}{l}\text { Utility Name } \\
\text { Plant Name } \\
\text { Supplier Name }\end{array}$ & Mine Name & $\begin{array}{l}\text { Mine } \\
\text { State }\end{array}$ & \begin{tabular}{|c|} 
Trans- \\
port \\
Mode
\end{tabular} & $\begin{array}{c}\text { Dis- } \\
\text { tance } \\
\text { (Miles) }\end{array}$ & \begin{tabular}{|c} 
Shipment \\
(Million \\
Short \\
Tons)
\end{tabular} & $\begin{array}{c}\text { Sulfur } \\
\text { (Percent } \\
\text { by } \\
\text { Weight) }\end{array}$ & $\begin{array}{c}\text { BTU } \\
\text { (Per } \\
\text { Pound) }\end{array}$ & $\begin{array}{c}\text { Mine- } \\
\text { mouth } \\
\text { Price } \\
\text { (1987 } \\
\text { Dollars) }\end{array}$ & \begin{tabular}{|c} 
Trans. \\
Rate \\
(1987 \\
Dollars)
\end{tabular} & $\begin{array}{c}\text { Del. } \\
\text { Price } \\
(1987 \\
\text { Dollars) }\end{array}$ \\
\hline \multicolumn{12}{|c|}{$\begin{array}{l}\text { Tampa Electric Co } \\
\text { Gannon }\end{array}$} \\
\hline 1999 & Gatliff Coal Co & Various & KY & $\begin{array}{l}\text { Multi- } \\
\text { mode }\end{array}$ & NA & 1.064 & 1.14 & 12,744 & NA & NA & 45.61 \\
\hline 1999 & Gatliff Coal Co & Various & KY & Rail & 850 & 1.064 & 1.14 & 12,744 & NA & NA & 45.61 \\
\hline \multicolumn{12}{|c|}{$\begin{array}{l}\text { Alabama Power Co } \\
\text { Barry }\end{array}$} \\
\hline \multicolumn{12}{|c|}{ Miller } \\
\hline 2000 & Drummond Co (Miller) & Various & $A L$ & Other & NA & 1.703 & 0.32 & 12,327 & NA & NA & 62.72 \\
\hline \multicolumn{12}{|c|}{$\begin{array}{l}\text { Appalachian Power Co } \\
\text { Amos }\end{array}$} \\
\hline 2000 & Arch Coal Sales Co & Ruffner, Wylo & WV & Rail & 118 & 0.068 & 0.63 & 12,600 & NA & NA & 24.36 \\
\hline 2000 & $\begin{array}{l}\text { Pittston Coal Sales } \\
\text { Mountaineer }\end{array}$ & Elkay, Bandmill Not & WV & Rail & 107 & 0.094 & 0.67 & 12,493 & NA & NA & 25.05 \\
\hline 2000 & Arch Coal Sales Co & Ruffner, Wylo & WV & $\begin{array}{l}\text { Multi- } \\
\text { mode }\end{array}$ & 180 & 0.069 & 0.63 & 12,399 & NA & NA & 26.53 \\
\hline 2000 & Pen Coal Corp & Various & WV & Barge & 82 & 0.396 & 0.61 & 12,032 & NA & NA & 25.97 \\
\hline 2000 & Pittston Coal Sales & Elkay, Bandmill Not & WV & $\begin{array}{l}\text { Multi- } \\
\text { mode }\end{array}$ & 169 & 0.101 & 0.67 & 12,467 & NA & NA & 27.50 \\
\hline
\end{tabular}

Arizona Public Service Co

Cholla

2000 Pittsburgh \& Midway

McKinley

NM Rail $\quad 116 \quad 2.059$

$0.42 \quad 9,968 \quad 21.66$

$6.13 \quad 27.80$

Black Hills Power \& Light Co

Ben French

2000 Wyodak Resources Dev

$2000 \quad$ Kirk $\quad$ Wyodak Resources Dev Fort Union

WY Truck $135 \quad 0.123$

0.31

$8,113 \quad 7.38$

5.92

13.30

Neil Simpson

2000

Wyodak Resources Dev Fort Union

WY Truck 100

0.799

0.56

$\begin{array}{llll}7,966 & 8.52 & 6.03 & 14.55\end{array}$

Osage

2000

Wyodak Resources Dev Fort Union

WY Other NA

0.130

$\begin{array}{llll}0.56 & 8,113 & 8.62 \quad N A\end{array}$

8.62

WY Truck $\quad 58 \quad 0.232$

$\begin{array}{lllll}0.56 & 7,978 & 8.63 & 2.84 & 11.47\end{array}$

Cincinnati Gas \& Electric Co

W H Zimmer

2000 Addington Inc

Ohio

$\mathrm{OH}$ Barge 118

0.797

$\begin{array}{llll}3.19 & 11,709 & 19.27 & 1.84\end{array}$

21.12

Detroit Edison Co

Belle River

2000 Spring Creek Coal Co Spring Creek

Monroe

2000

Spring Creek Coal Co

Spring Creek

MT $\begin{gathered}\text { Multi- } \\ \text { mode }\end{gathered}$

$\begin{array}{lllll}0.36 & 9,337 & N A & N A & 19.27\end{array}$

$\begin{array}{lll}\text { MT Rail } & 1490 \quad 0.097\end{array}$

$0.318,823 \quad N A$

NA $\quad 19.06$

See notes at end of table. 
Table B1. Utility Contract Coal Shipment in 1993 by Expiration Date (Continued)

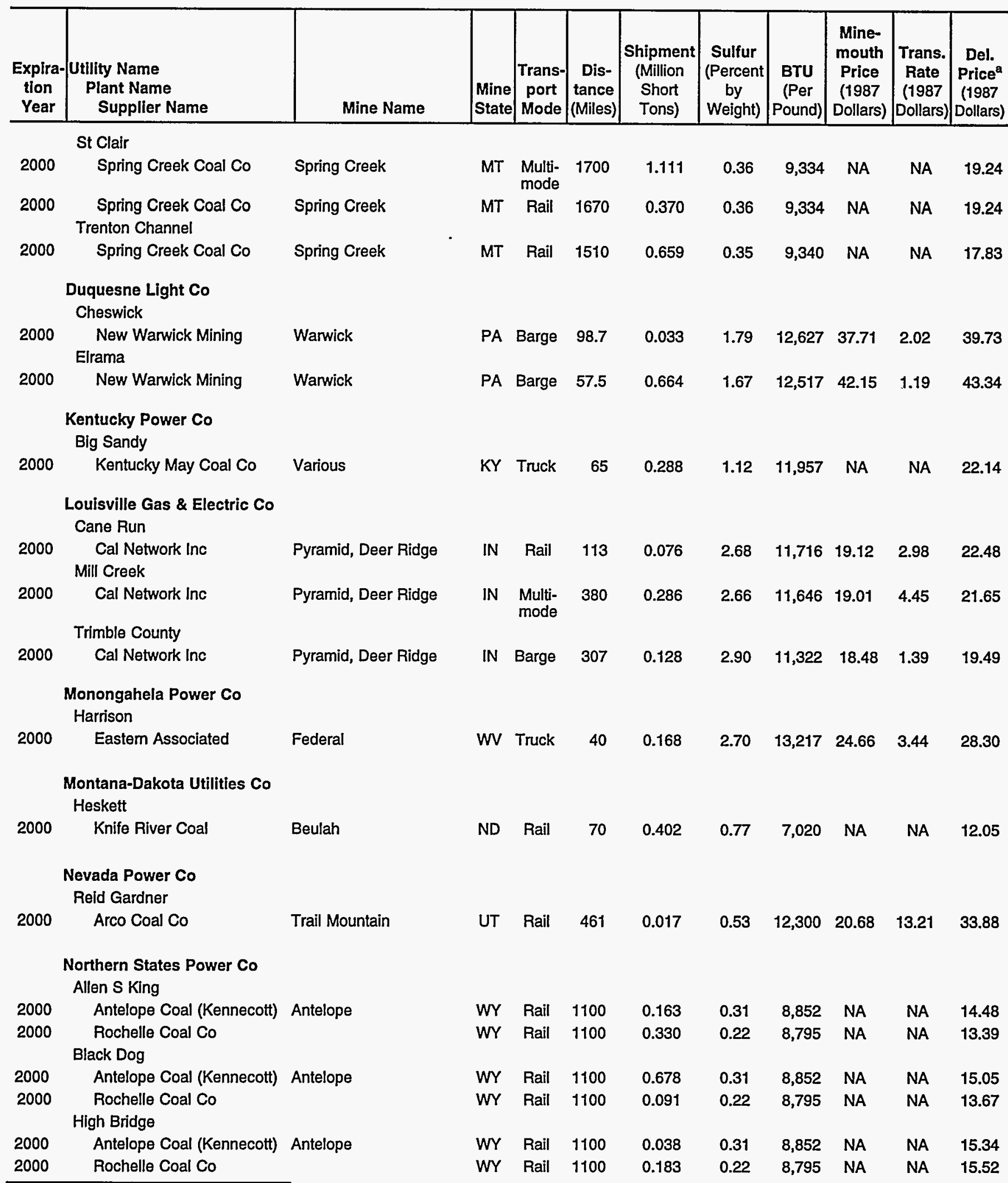

See notes at end of page. 
Table B1. Utility Contract Coal Shipment in 1993 by Expiration Date (Continued)

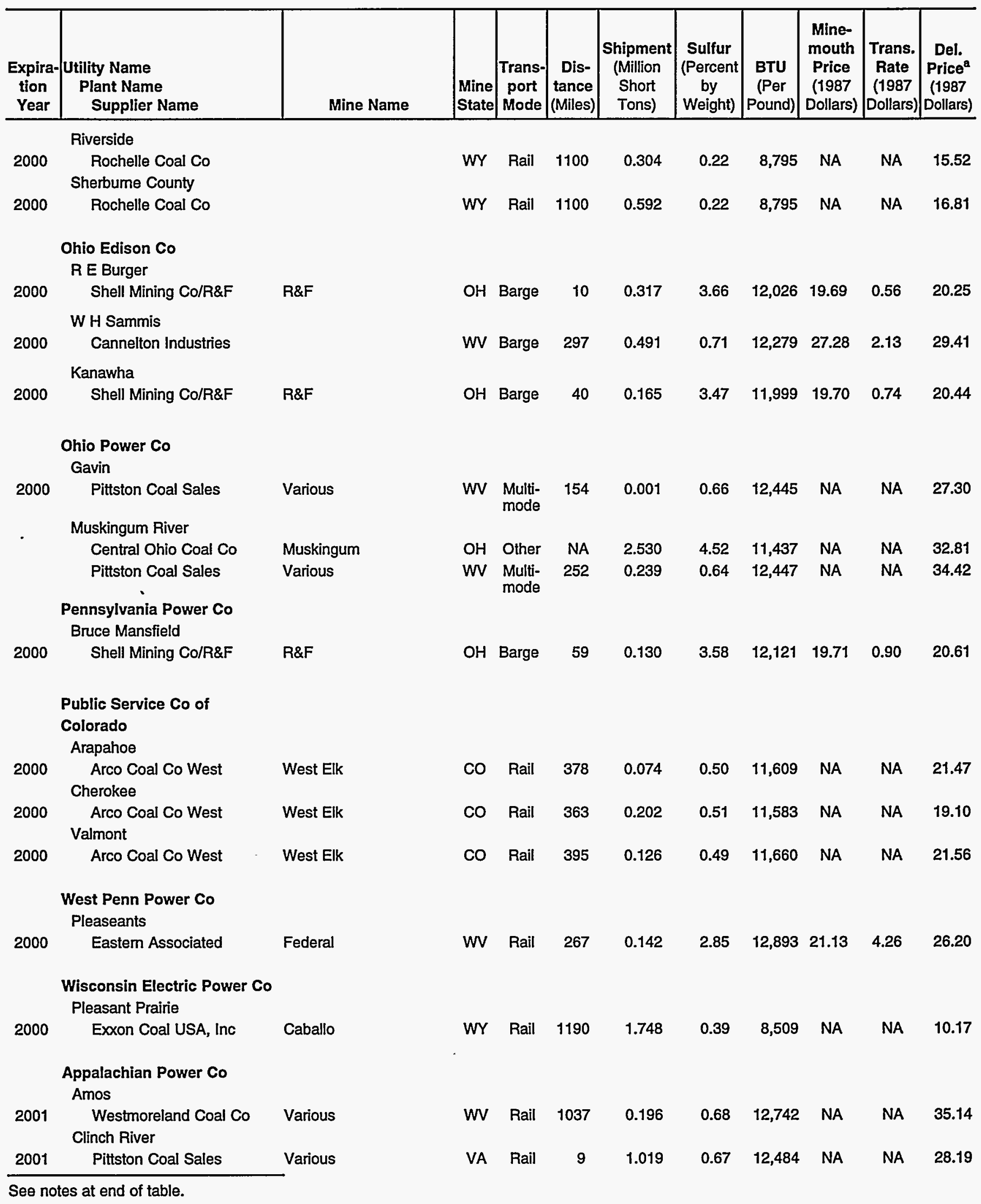


Table B1. Utility Contract Coal Shipment in 1993 by Expiration Date (Continued)

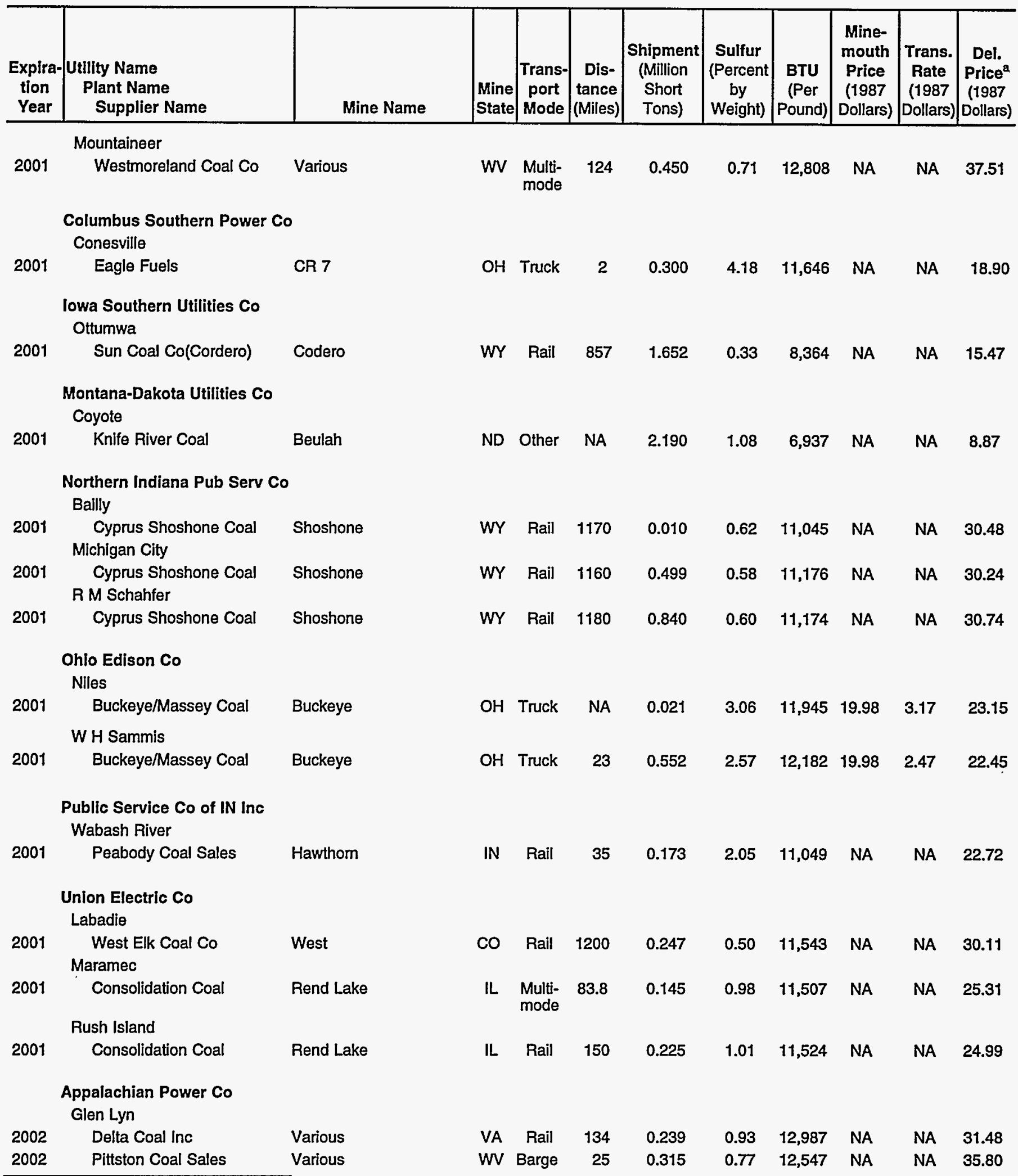

See notes at end of table. 
Table B1. Utility Contract Coal Shipment in 1993 by Expiration Date (Continued)

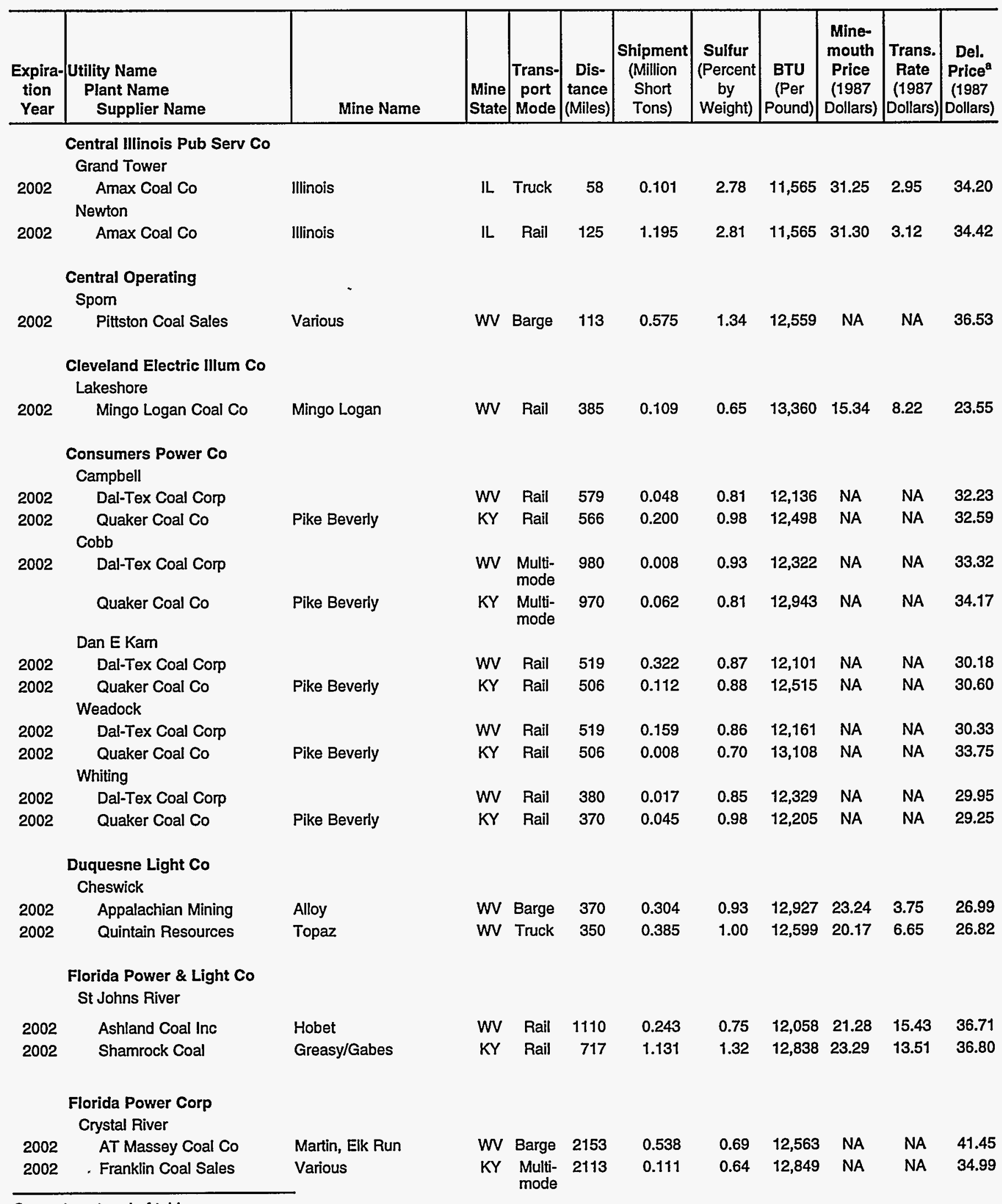

See notes at end of table. 
Table B1. Utility Contract Coal Shipment in 1993 by Expiration Date (Continued)

\begin{tabular}{|c|c|c|c|c|c|c|c|c|c|c|c|}
\hline 2002 & Franklin Coal Sales & Various & KY & Rail & 823 & 0.111 & 0.64 & 12,849 & NA & NA & 34.99 \\
\hline 2002 & Powell Mountain & Mayflower & VA & Rail & 786 & 0.834 & 0.71 & 12,345 & NA & NA & 43.64 \\
\hline
\end{tabular}

Monongahela Power Co

Harrison

2002 Consolidation Coal

Ohio Edison Co

RE Burger

$\begin{array}{cc}2002 & \text { Quaker Coal Co } \\ 2002 & \text { Quaker Coal Co } \\ & \text { Toronto } \\ 2002 & \text { Quaker Coal Co } \\ & \text { W H Sammis } \\ 2002 & \text { Ashland Coal Co } \\ 2002 & \text { Quaker Coal Co } \\ & \\ & \begin{array}{c}\text { Potomac Electric Power Co } \\ \text { Potomac River }\end{array} \\ 2002 & \text { Southeast Fuels Inc }\end{array}$

Public Service Co of IN Inc

Cayuga

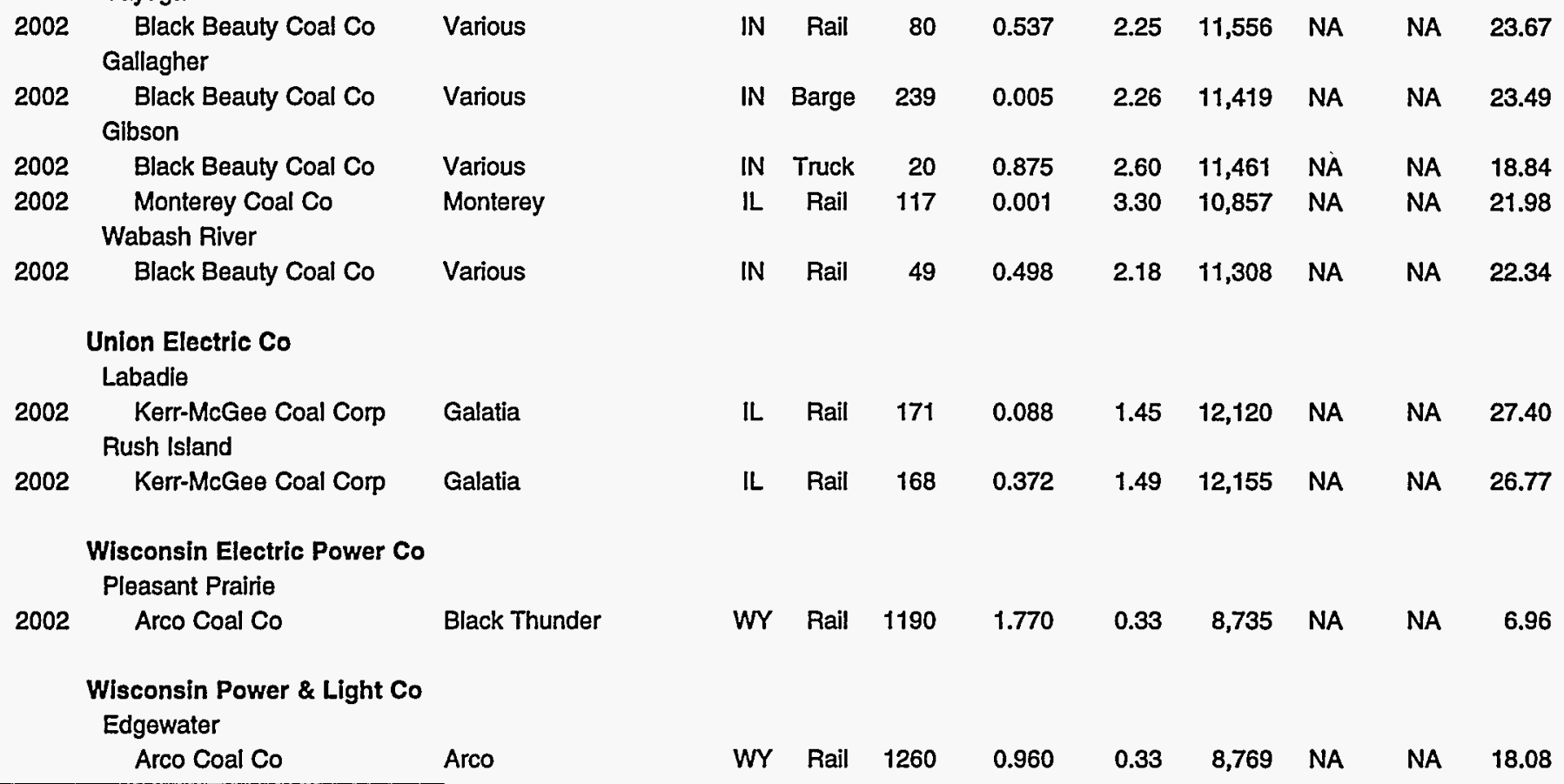

See notes at end of table.

\section{Samara, River Ridge}

WV Rail 410

0.183

0.7

$\begin{array}{llll}12,796 & 21.10 & 14.79 & 35.89\end{array}$

$\begin{array}{llllllllll}\text { Nelms } & \text { OH Barge } & 10 & 0.247 & 3.35 & 12,237 & 18.37 & 3.37 & 21.74 \\ \text { Nelms } & \text { OH Truck } & 50 & 0.247 & 3.35 & 12,237 & 18.37 & 3.37 & 21.74 \\ \text { Nelms } & \text { OH } & \text { Truck } & 40 & 0.009 & 3.27 & 12,330 & 18.33 & 2.88 & 21.21 \\ & & & & & & & & & \\ \text { Various } & \text { KY } & \text { Barge } & 267 & 0.677 & 0.86 & 12,106 & 24.00 & 1.53 & 25.53 \\ \text { Nelms } & \text { OH } & \text { Truck } & 38 & 0.105 & 3.41 & 12,291 & 18.33 & 3.09 & 21.42\end{array}$

Robinson Run

WV Other NA

2.349

2.0

$13,17933.27 \quad$ NA

33.27 
Table B1. Utility Contract Coal Shipment in 1993 by Expiration Date (Continued)

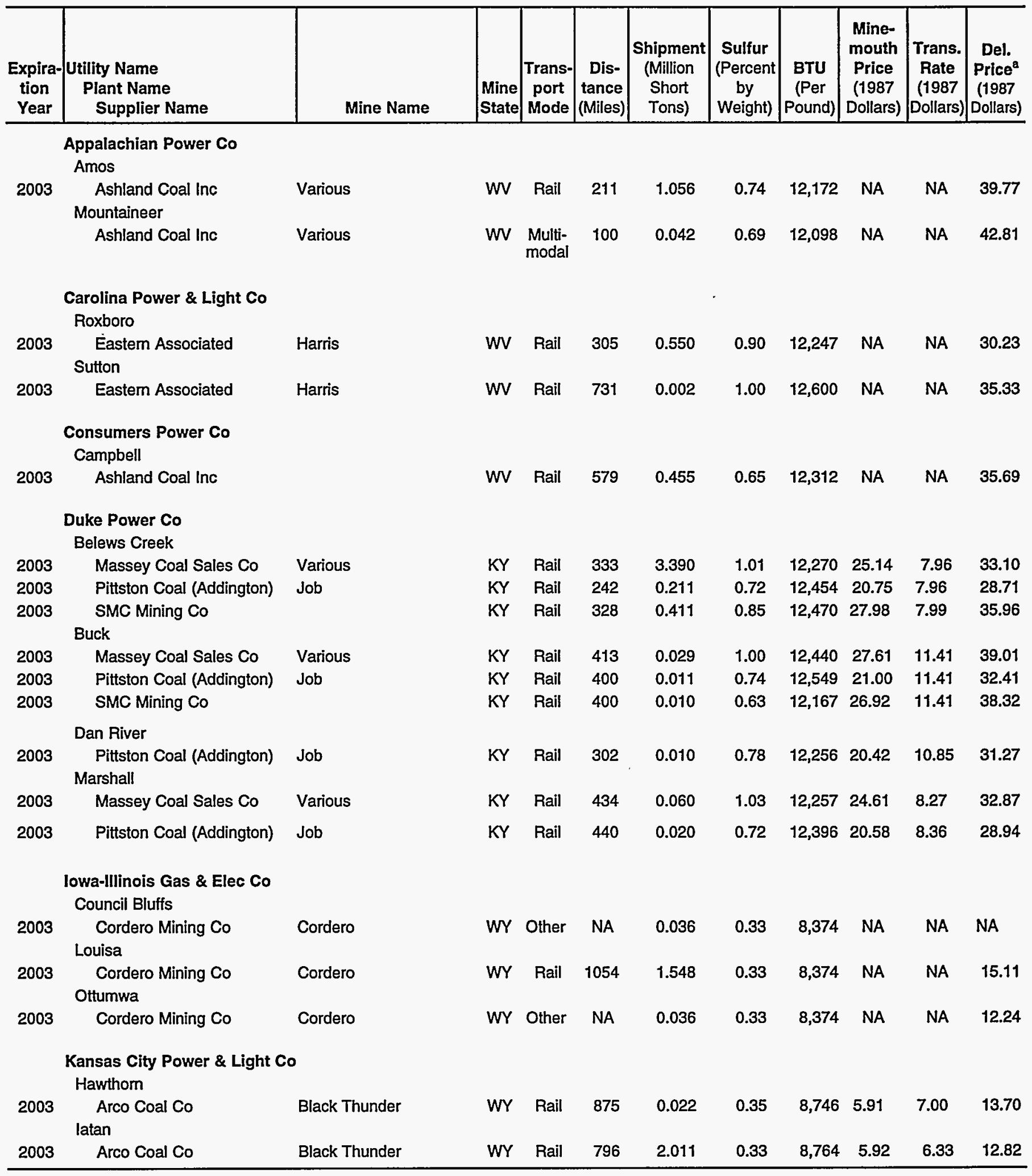

See notes at end of table. 
Table B1. Utility Contract Coal Shipment in 1993 by Expiration Date (Continued)

\begin{tabular}{|c|c|c|c|c|c|c|c|c|c|c|c|}
\hline $\begin{array}{c}\text { Explra- } \\
\text { tion } \\
\text { Year } \\
\end{array}$ & $\begin{array}{l}\text { Utility Name } \\
\text { Plant Name } \\
\text { Supplier Name }\end{array}$ & Mine Name & $\begin{array}{l}\text { Mine } \\
\text { State }\end{array}$ & $\begin{array}{c}\text { Trans- } \\
\text { port } \\
\text { Mode }\end{array}$ & $\begin{array}{c}\text { Dis- } \\
\text { tance } \\
\text { (Miles) }\end{array}$ & $\begin{array}{c}\text { Shipment } \\
\text { (Million } \\
\text { Short } \\
\text { Tons) }\end{array}$ & $\begin{array}{c}\text { Sulfur } \\
\text { (Percent } \\
\text { by } \\
\text { Weight) }\end{array}$ & $\begin{array}{c}\text { BTU } \\
\text { (Per } \\
\text { Pound) }\end{array}$ & $\begin{array}{l}\text { Mine- } \\
\text { mouth } \\
\text { Price } \\
\text { (1987 } \\
\text { Dollars) }\end{array}$ & $\begin{array}{c}\text { Trans. } \\
\text { Rate } \\
\text { (1987 } \\
\text { Dollars) }\end{array}$ & $\begin{array}{c}\text { Del. } \\
\text { Pricea } \\
\text { (1987 } \\
\text { Dollars) }\end{array}$ \\
\hline \multicolumn{12}{|c|}{ LaCygne } \\
\hline 2003 & Arco Coal Co & Black Thunder & WY & Rail & 875 & 0.024 & 0.28 & 8,767 & 5.96 & 7.88 & 14.31 \\
\hline \multicolumn{12}{|c|}{$\begin{array}{l}\text { Ohio Edison Co } \\
\text { W H Sammis }\end{array}$} \\
\hline 2003 & W B Coal Co & Ann & $\mathrm{OH}$ & Barge & 277 & 0.329 & 1.96 & 12,117 & 23.04 & 1.82 & 25.74 \\
\hline 2003 & W B Coal Co & Ann & $\mathrm{OH}$ & Truck & 23 & 0.329 & 1.96 & 12,117 & 23.04 & 2.71 & 25.74 \\
\hline \multicolumn{12}{|c|}{$\begin{array}{l}\text { Oklahoma Gas \& Electric Co } \\
\text { Muskogee }\end{array}$} \\
\hline \multicolumn{12}{|c|}{ Sooner } \\
\hline 2003 & Thunder Basin Coal Co & Thunder Basin & WY & Rail & 931 & 3.017 & 0.33 & 8,767 & 6.98 & 8.90 & 16.66 \\
\hline \multicolumn{12}{|c|}{$\begin{array}{l}\text { Potomac Electric Power Co } \\
\text { Potomac River }\end{array}$} \\
\hline 2003 & Costain Coal Inc & Pax & WV & Rail & 360 & 0.064 & 0.79 & 13,427 & 21.41 & 14.44 & 35.85 \\
\hline 2003 & Southeast Fuel Inc & Glen Alum & WV & Rail & 410 & 0.053 & 0.78 & 12,978 & 20.73 & 14.70 & 35.41 \\
\hline \multicolumn{12}{|c|}{$\begin{array}{l}\text { Public Service Co of IN Inc } \\
\text { Cayuga }\end{array}$} \\
\hline 2003 & Peabody Coal Sales & & IN & Rail & 70 & 1.003 & 2.02 & 11,084 & NA & NA & 24.41 \\
\hline \multicolumn{12}{|c|}{$\begin{array}{l}\text { Sierra Pacific Power Co } \\
\text { North Valmy }\end{array}$} \\
\hline \multicolumn{12}{|c|}{$\begin{array}{l}\text { Carolina Power \& Light Co } \\
\text { Cape Fear }\end{array}$} \\
\hline 2004 & $\begin{array}{l}\text { Shell Mining Company } \\
\text { Lee }\end{array}$ & Wolk Creek & WV & Rail & 385 & 0.328 & 1.03 & 12,767 & NA & NA & 44.65 \\
\hline 2004 & $\begin{array}{l}\text { Shell Mining Company } \\
\text { Robinson }\end{array}$ & Wolk Creek & WV & Rail & 500 & 0.304 & 1.06 & 12,843 & NA & NA & 45.56 \\
\hline 2004 & $\begin{array}{l}\text { Shell Mining Company } \\
\text { Roxboro }\end{array}$ & Wolk Creek & WV & Rail & 500 & 0.120 & 1.12 & 12,847 & NA & NA & 48.37 \\
\hline 2004 & Shell Mining Company & Wolk Creek & WV & Rail & 335 & 1.008 & 1.03 & 12,797 & NA & NA & 42.80 \\
\hline \multicolumn{12}{|c|}{$\begin{array}{l}\text { Central Louisiana Elec Co Inc } \\
\text { Dolet Hills }\end{array}$} \\
\hline 2004 & \multicolumn{10}{|l|}{$\begin{array}{l}\text { Consumers Power Co } \\
\text { Campbell }\end{array}$} & 17.84 \\
\hline 2004 & Ashland Coal Inc & & WV & Rail & 579 & 0.081 & 0.77 & 12,216 & NA & NA & 35.21 \\
\hline
\end{tabular}

See notes at end of table. 
Table B1. Utility Contract Coal Shipment in 1993 by Expiration Date (Continued)

\begin{tabular}{|c|c|c|c|c|c|c|c|c|c|c|c|}
\hline $\begin{array}{l}\text { Expira- } \\
\text { tion } \\
\text { Year }\end{array}$ & $\begin{array}{l}\text { Utility Name } \\
\text { Plant Name } \\
\text { Supplier Name }\end{array}$ & Mine Name & $\begin{array}{l}\text { Mine } \\
\text { State }\end{array}$ & $\begin{array}{c}\text { Trans- } \\
\text { port } \\
\text { Mode }\end{array}$ & $\begin{array}{r}\text { Dis- } \\
\text { tance } \\
\text { (Miles) }\end{array}$ & $\begin{array}{c}\text { Shipment } \\
\text { (Million } \\
\text { Short } \\
\text { Tons) }\end{array}$ & $\begin{array}{c}\text { Sulfur } \\
\text { (Percent } \\
\text { by } \\
\text { Weight) }\end{array}$ & $\mid \begin{array}{c}\text { BTU } \\
\text { (Per } \\
\text { Pound) }\end{array}$ & $\begin{array}{l}\text { Mine- } \\
\text { mouth } \\
\text { Price } \\
\text { (1987 } \\
\text { Dollars) }\end{array}$ & \begin{tabular}{|c|} 
Trans. \\
Rate \\
(1987 \\
Dollars)
\end{tabular} & $\begin{array}{c}\text { Del. } \\
\text { Price }^{\mathrm{a}} \\
\text { (1987 } \\
\text { Dollars) }\end{array}$ \\
\hline \multicolumn{12}{|c|}{ Cobb } \\
\hline \multicolumn{12}{|c|}{ Dan E Kam } \\
\hline \multicolumn{12}{|c|}{ Weadock } \\
\hline \multicolumn{11}{|c|}{ Whiting } & 32.67 \\
\hline 2004 & Ashland Coal Inc & & wV & Rail & 380 & 0.013 & 0.83 & 12,280 & NA & NA & 31.82 \\
\hline \multicolumn{12}{|c|}{$\begin{array}{l}\text { Empire District Electric Co } \\
\text { Asbury }\end{array}$} \\
\hline 2004 & \multicolumn{8}{|l|}{ Riverton } & NA & NA & 13.62 \\
\hline \multicolumn{12}{|c|}{$\begin{array}{l}\text { Gulf States Utilities Co } \\
\text { Nelson }\end{array}$} \\
\hline 2004 & \multicolumn{11}{|c|}{$\begin{array}{l}\text { Indiana \& Michigan Power Co } \\
\text { Rockport }\end{array}$} \\
\hline 2004 & Rochelle Coal Co & Rochelle, North Antelope & WY & $\begin{array}{l}\text { Multi- } \\
\text { mode }\end{array}$ & 1475 & 2.807 & 0.21 & 8,784 & NA & NA & 15.63 \\
\hline \multicolumn{12}{|c|}{ Nevada Power Co } \\
\hline 2004 & \multicolumn{10}{|l|}{$\begin{array}{l}\text { Ohio Power Co } \\
\text { Gavin }\end{array}$} & 33.88 \\
\hline \multicolumn{12}{|c|}{ Tidd } \\
\hline 2004 & Sands Hill Coal Co & Various & $\mathrm{OH}$ & Barge & 188 & 0.000 & 3.30 & 11,371 & NA & NA & 21.81 \\
\hline \multicolumn{12}{|c|}{$\begin{array}{l}\text { Pennsylvania Electric Co } \\
\text { Keystone }\end{array}$} \\
\hline \multicolumn{12}{|c|}{$\begin{array}{l}\text { Tampa Electric Co } \\
\text { Big Bend }\end{array}$} \\
\hline 2004 & Old Ben Coal (Zeigler) & Spartan & IL & Barge & NA & 0.985 & 2.61 & 11,011 & NA & NA & 36.23 \\
\hline 2004 & Peabody Develop Co & Wheatcroft, Hamilton & $\mathrm{KY}$ & Barge & NA & 0.715 & 2.96 & 12,489 & NA & NA & 41.22 \\
\hline
\end{tabular}

Tri-State Generation \&

Transmission Assn

Hayden

2004 Peabody Coal Sales

Seneca

CO Other NA

$0.726 \quad N A$

NA NA NA NA

See notes at end of table. 
Table B1. Utility Contract Coal Shipment in 1993 by Expiration Date (Continued)

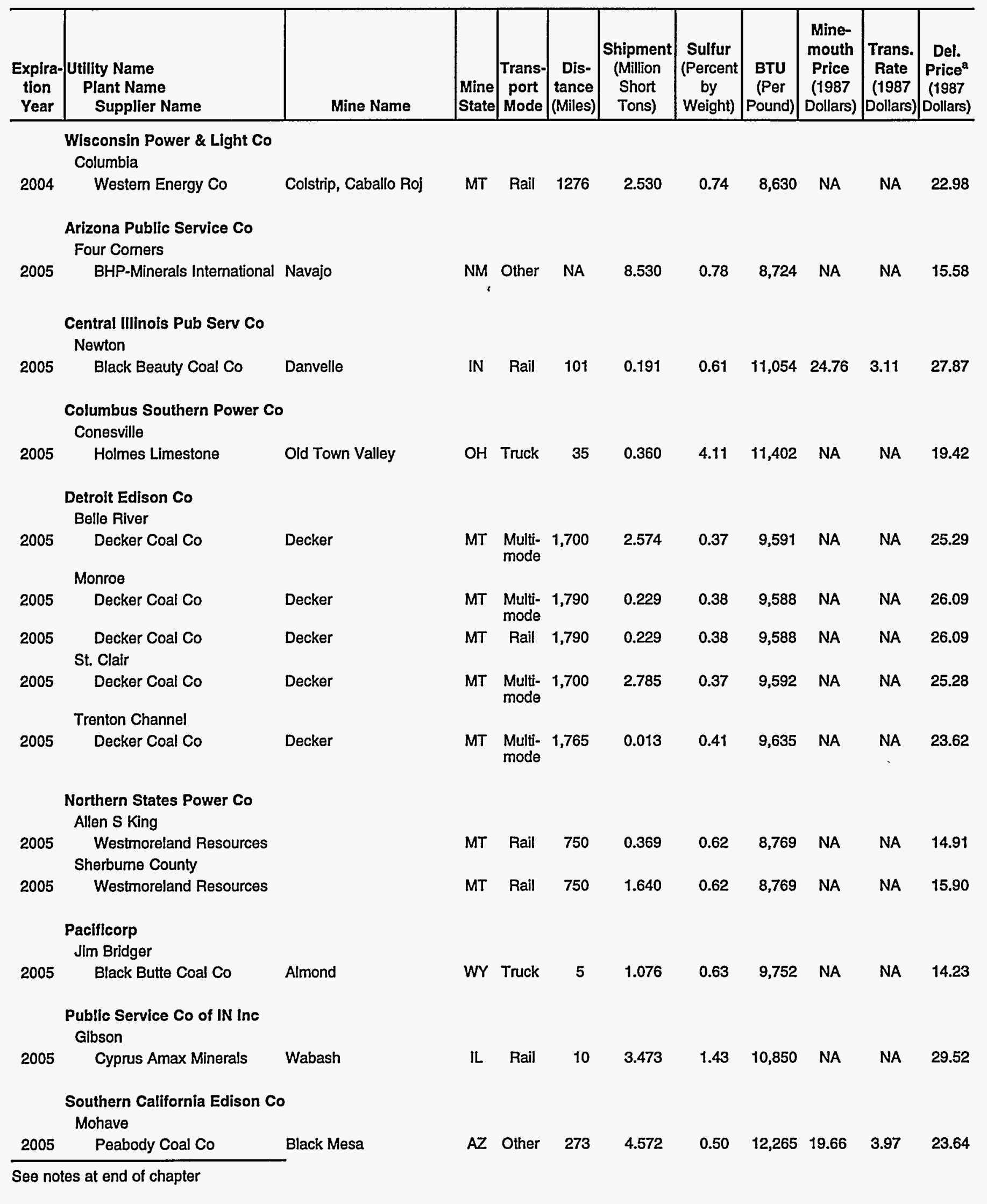


Table B1. Utility Contract Coal Shipment in 1993 by Expiration Date (Continued)

\begin{tabular}{|c|c|c|c|c|c|c|c|c|c|c|c|}
\hline 2005 & \multicolumn{11}{|c|}{$\begin{array}{l}\text { Wisconsin Electric Power Co } \\
\text { Pleasant Prairie }\end{array}$} \\
\hline \multicolumn{12}{|c|}{ Appalachian Power Co } \\
\hline \multicolumn{12}{|c|}{ Amos } \\
\hline 2006 & Pittston Coal Sales & Various & WV & Rail & 107 & 0.137 & 0.65 & 12,139 & NA & NA & 23.61 \\
\hline \multicolumn{12}{|c|}{ Mountaineer } \\
\hline
\end{tabular}

Carolina Power \& Light Co

Cape Fear

\begin{tabular}{|c|c|c|c|c|c|c|c|c|c|c|c|}
\hline \multicolumn{12}{|c|}{$\begin{array}{l}\text { Shell Miming Co } \\
\text { Mayo }\end{array}$} \\
\hline 2006 & $\begin{array}{l}\text { Shell Miming Co } \\
\text { Jxboro }\end{array}$ & Marrowbone & WV & Rail & 335 & 1.559 & 0.66 & 12,128 & NA & NA & 37.66 \\
\hline 2006 & Shell Miming Co & Marrowbone & WV & Rail & 335 & 1.178 & 0.67 & 12,059 & NA & NA & 37.44 \\
\hline \multicolumn{12}{|c|}{$\begin{array}{r}\text { Pacificorp } \\
\text { Centralia }\end{array}$} \\
\hline 2006 & $\begin{array}{l}\text { Centralia Mining Co } \\
\text { aughton }\end{array}$ & Various & WA & Other & NA & 4.518 & 0.76 & $\begin{array}{l}7,871 \\
\cdot\end{array}$ & NA & NA & 17.58 \\
\hline 2006 & $\begin{array}{l}\text { Pittsburg \& Midway } \\
\text { st Texas Utilities Co } \\
\text { dlaunion }\end{array}$ & Adaville & \multicolumn{9}{|c|}{$\begin{array}{l}\text { West Texas Utilities Co } \\
\text { Oklaunion }\end{array}$} \\
\hline \multicolumn{12}{|c|}{$\begin{array}{l}\text { Central Louisiana Elec Co Inc } \\
\text { Rodemacher }\end{array}$} \\
\hline 2007 & $\begin{array}{l}\text { Kerr-McGee Coal Corp } \\
\text { f Power Co } \\
\text { ist }\end{array}$ & Wyodak & WY & Rail & 1596 & 1.924 & 0.45 & 8,643 & NA & NA & 26.03 \\
\hline 2007 & $\begin{array}{l}\text { Peabody Coal Co } \\
\text { nith }\end{array}$ & Eagle & $\mathrm{KY}$ & Barge & 1179 & 0.669 & 2.83 & 12,006 & NA & NA & 39.27 \\
\hline 2007 & $\begin{array}{l}\text { Peabody Coal Co } \\
\text { ianapolis Power \& Ligh } \\
\text { tersburg }\end{array}$ & Eagle & KY & Barge & 1256 & 0.237 & 2.83 & 12,003 & NA & NA & 39.85 \\
\hline 2007 & $\begin{array}{l}\text { Peabody Coal Co } \\
\text { sissippi Power Co } \\
\text { aniel }\end{array}$ & Lynnville & IN & Rail & 28 & 1.888 & 2.96 & 11,024 & 16.78 & 1.22 & 18.07 \\
\hline 2007 & Golden Oak Mining Co & Sapphire Tipple & KY & Rail & 950 & 0.775 & 0.69 & 12,877 & NA & NA & 36.25 \\
\hline
\end{tabular}

See notes at end of table 
Table B1. Utility Contract Coal Shipment in 1993 by Expiration Date (Continued)

\begin{tabular}{|c|c|c|c|c|c|c|c|c|c|c|c|}
\hline $\begin{array}{l}\text { Expira- } \\
\text { tion } \\
\text { Year }\end{array}$ & $\begin{array}{l}\text { Utility Name } \\
\text { Plant Name } \\
\text { Supplier Name }\end{array}$ & Mine Name & $\begin{array}{l}\text { Mine } \\
\text { State }\end{array}$ & $\begin{array}{c}\text { Trans- } \\
\text { port } \\
\text { Mode }\end{array}$ & $\begin{array}{c}\text { Dis- } \\
\text { tance } \\
\text { (Miles) }\end{array}$ & $\begin{array}{c}\text { Shipment } \\
\text { (Million } \\
\text { Short } \\
\text { Tons) }\end{array}$ & $\begin{array}{c}\text { Sulfur } \\
\text { (Percent } \\
\text { by } \\
\text { Weight) }\end{array}$ & $\begin{array}{c}\text { BTU } \\
\text { (Per } \\
\text { Pound) }\end{array}$ & $\begin{array}{c}\text { Mine- } \\
\text { mouth } \\
\text { Price } \\
\text { (1987 } \\
\text { Dollars) }\end{array}$ & $\begin{array}{c}\text { Trans. } \\
\text { Rate } \\
(1987 \\
\text { Dollars })\end{array}$ & $\begin{array}{l}\text { Del. } \\
\text { Price }^{\mathrm{a}} \\
\text { (1987 } \\
\text { Dollars) }\end{array}$ \\
\hline \multicolumn{12}{|c|}{$\begin{array}{l}\text { Nevada Power Co } \\
\text { Reid Gardner }\end{array}$} \\
\hline 2007 & Arco & Gorden Creek, Mt Gunn & UT & Rail & 461 & 0.295 & 0.54 & 11,680 & 23.88 & 12.54 & 36.54 \\
\hline 2007 & Co-op Mining Co & Bear Canyon & UT & Rail & 461 & 0.017 & 0.50 & 11,251 & 18.84 & 12.08 & 30.40 \\
\hline 2007 & Cyprus Western Coal & Star Point & UT & Rail & 448 & 0.480 & 0.51 & 11,856 & 18.60 & 12.73 & 31.27 \\
\hline \multicolumn{12}{|c|}{$\begin{array}{l}\text { Orange \& Rockland Utilities Inc } \\
\text { Lovett }\end{array}$} \\
\hline 2007 & AT Massey Coal Sales & Raul, Sidney & KY & Rail & 709 & 0.216 & 0.57 & 12,961 & 26.07 & 16.41 & 42.50 \\
\hline 2007 & Pittston Coal Sales & Stone, Holstone & KY & Rail & 709 & 0.313 & 0.53 & 13,093 & 27.35 & 16.58 & 43.74 \\
\hline \multicolumn{12}{|c|}{$\begin{array}{l}\text { Sierra Pacific Power Co } \\
\text { North Valmy }\end{array}$} \\
\hline 2007 & Black Butte Coal Co & Black Butte & WY & Rail & 546 & 0.971 & 0.44 & 9,625 & 22.60 & 7.03 & 29.63 \\
\hline \multicolumn{12}{|c|}{$\begin{array}{l}\text { United Illuminating Co } \\
\text { Bridgeport Harbor }\end{array}$} \\
\hline 2007 & Pittston Coal Sales & & $\mathrm{KY}$ & Rail & 860 & 0.745 & 0.55 & 13,147 & 21.87 & 14.77 & 36.64 \\
\hline \multicolumn{12}{|c|}{$\begin{array}{l}\text { Wisconsin Electric Power Co } \\
\text { Oak Creek }\end{array}$} \\
\hline 2007 & $P \& M$ Coal & York Cannon & $\mathrm{NM}$ & Rail & 1270 & 0.866 & 0.51 & 12,474 & NA & NA & 33.61 \\
\hline 2007 & $P \& M$ Coal & York Cannon & NM & Rail & 1260 & 0.866 & 0.51 & 12,474 & NA & NA & 33.61 \\
\hline \multicolumn{12}{|c|}{$\begin{array}{l}\text { Indianapolis Power \& Light Co } \\
\text { H T Pritchard }\end{array}$} \\
\hline 2009 & Coal Inc & Fourth Vien & IN & Rail & 65 & 0.011 & 0.97 & 11,533 & 19.39 & 2.99 & 22.29 \\
\hline \multicolumn{12}{|c|}{$\begin{array}{l}\text { Montana Power Co } \\
\text { Colstrip }\end{array}$} \\
\hline 2009 & Western Energy Co & Rosebud & MT & Other & NA & 2.746 & 0.64 & 8,607 & NA & NA & 7.85 \\
\hline \multicolumn{12}{|c|}{$\begin{array}{l}\text { Public Service Co of } \\
\text { Oklahoma }\end{array}$} \\
\hline 2009 & Kerr-McGee Coal Co & Jacobs Ranch & WY & Rail & 1037 & 3.311 & 0.45 & 8,624 & NA & NA & 22.35 \\
\hline \multicolumn{12}{|c|}{$\begin{array}{l}\text { Tucson Electric Power Co } \\
\text { Springerville }\end{array}$} \\
\hline 2009 & Santa Fe Pacific & Lee Ranch & NM & Rail & 212 & 2.995 & 0.68 & 9,078 & NA & NA & 23.68 \\
\hline \multicolumn{12}{|c|}{$\begin{array}{l}\text { Central Illinois Light Co } \\
\text { Duck Creek }\end{array}$} \\
\hline 2010 & Freeman United Coal & Crown & IL & Rail & 106 & 0.923 & 3.40 & 10,721 & NA & NA & 31.30 \\
\hline
\end{tabular}


Table B1. Utility Contract Coal Shipment in 1993 by Expiration Date (Continued)

\begin{tabular}{|c|c|c|c|c|c|c|c|c|c|c|c|}
\hline \multicolumn{12}{|c|}{ E D Edwards } \\
\hline 2010 & Freeman United Coal & Crown & IL & Rail & 106 & 0.040 & 3.50 & 10,716 & NA & NA & 34.62 \\
\hline \multicolumn{12}{|c|}{$\begin{array}{l}\text { Central Illinois Pub Serv Co } \\
\text { Coffeen }\end{array}$} \\
\hline 2010 & Exxon Coal USA Inc & No 1 & IL & Rail & 71 & 1.616 & 2.76 & 10,500 & 25.04 & 2.30 & 27.33 \\
\hline \multicolumn{12}{|c|}{$\begin{array}{l}\text { Central Louisiana Elec Co Inc } \\
\text { Dolet Hills }\end{array}$} \\
\hline \multicolumn{12}{|c|}{$\begin{array}{l}\text { Illinois Power Co } \\
\text { Baldwin }\end{array}$} \\
\hline 2010 & $\begin{array}{l}\text { Peabody Coal Co } \\
\text { Hennepin }\end{array}$ & Various & IL & Rail & 5 & 1.903 & 2.89 & 10,775 & 24.07 & 0.30 & 24.37 \\
\hline 2010 & Peabody Coal Co & Various & IL & $\begin{array}{l}\text { Multi- } \\
\text { mode }\end{array}$ & 322 & 0.413 & 2.89 & 10,775 & 24.07 & 3.59 & 28.07 \\
\hline
\end{tabular}

Arkansas Power \& Light Independence

Kerr-McGee Coal Corp

White Bluff

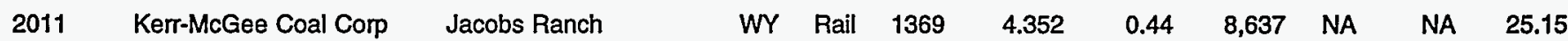

Columbus Southern Power

Conesville

2011

$R$ \& F Coal

Various

$\mathrm{OH}$ Truck $\quad 4 \quad 1.600$

$3.9311,311 \quad N A \quad N A$

29.03

Arkansas Power \& Light

Independence

2012

North Antelope

White Bluff

North Antelope

North Antelope

WY Rail $1424 \quad 3.690$

$0.21 \quad 8,815 \quad N A$

NA

24.10

North Antelope

WY Rail

0.669

0.21

8,36 NA

NA $\quad 25.64$

Cardinal Operating

Cardinal

2012

Arch Coal Sales

Various

WV Barge

238

0.692

$0.6912,022 \quad N A$

NA $\quad 31.44$

Ohio Power Co

Mitchell

$\begin{array}{lllllllllll}2012 & \text { Peabody Coal Co } & \text { Various } & \text { WV Barge } & 228 & 0.825 & 1.22 & 12,180 & \text { NA } & \text { NA } & 29.27 \\ 2012 & \begin{array}{c}\text { Peabody Coal Co } \\ \text { Tidd }\end{array} & \text { Various } & \text { WV Rail } & 117 & 0.825 & 1.22 & 12,180 & \text { NA } & \text { NA } & 29.27 \\ 2012 & \text { Peabody Coal Co } & \text { Various } & \text { WV Barge } & 20 & 0.003 & 1.44 & 11,767 & \text { NA } & \text { NA } & 27.23\end{array}$

See notes at end of table. 
Table B1. Utility Contract Coal Shipment in 1993 by Expiration Date (Continued)

\begin{tabular}{|c|c|c|c|c|c|c|c|c|c|c|c|}
\hline $\begin{array}{c}\text { Expira- } \\
\text { tion } \\
\text { Year } \\
\end{array}$ & $\begin{array}{l}\text { Utility Name } \\
\text { Plant Name } \\
\text { Supplier Name }\end{array}$ & Mine Name & $\begin{array}{l}\text { Mine } \\
\text { State }\end{array}$ & $\begin{array}{c}\text { Trans- } \\
\text { port } \\
\text { Mode }\end{array}$ & $-\begin{array}{c}\text { Dis- } \\
\text { tance } \\
\text { (Miles) }\end{array}$ & $\begin{array}{c}\text { Shipment } \\
\text { (Million } \\
\text { Short } \\
\text { Tons) } \\
\end{array}$ & $\begin{array}{c}\text { Sulfur } \\
\text { (Percent } \\
\text { by } \\
\text { Weight) }\end{array}$ & $\begin{array}{c}\text { BTU } \\
\text { (Per } \\
\text { Pound) }\end{array}$ & $\begin{array}{c}\text { Mine- } \\
\text { mouth } \\
\text { Price } \\
\text { (1987 } \\
\text { Dollars) }\end{array}$ & $\begin{array}{c}\text { Trans. } \\
\text { Rate } \\
(1987 \\
\text { Dollars })\end{array}$ & $\begin{array}{l}\text { Del. } \\
\text { Price }^{a} \\
\text { (1987 } \\
\text { Dollars) }\end{array}$ \\
\hline & \multicolumn{11}{|l|}{$\begin{array}{l}\text { Kansas Power \& Light Co } \\
\text { Jeffrey Energy Cnt }\end{array}$} \\
\hline 2013 & Amax Coal West(Jeff) & Eagle Butte, Belle & WY & Rail & 705.3 & 7.678 & 0.33 & 8,255 & NA & NA & 13.98 \\
\hline & \multicolumn{11}{|l|}{ Pacificorp } \\
\hline & \multicolumn{11}{|l|}{ Wyodak } \\
\hline 2013 & Wyodak Resource & Wyodak & WY & Other & NA & 2.085 & 0.55 & 7,967 & NA & NA & 8.30 \\
\hline & \multicolumn{11}{|c|}{$\begin{array}{l}\text { Indlana \& Michigan Power Co } \\
\text { Rockport }\end{array}$} \\
\hline 2014 & Exxon Coal USA Inc & Rowhide, Caballo & WY & $\begin{array}{l}\text { Multi- } \\
\text { mode }\end{array}$ & 1,475 & 3.700 & 0.37 & 8,440 & NA & NA & 14.86 \\
\hline & \multicolumn{11}{|l|}{$\begin{array}{l}\text { Pacificorp } \\
\text { Jim Bridger }\end{array}$} \\
\hline 2014 & Bridger Coal Co & Fort Union, Dietz & WY & Truck & NA & 6.406 & 0.59 & 9,498 & NA & NA & 16.65 \\
\hline & \multicolumn{11}{|l|}{$\begin{array}{l}\text { Public Service Co of } \\
\text { Colorado } \\
\text { Comanche }\end{array}$} \\
\hline 2014 & \multicolumn{11}{|l|}{ Pawnee } \\
\hline 2014 & Cyprus/Amax Coal Co & Belle Aye, Eagle Butt & Wr & Rail & 368 & 2.144 & 0.35 & 8,274 & NA & NA & 14.36 \\
\hline & \multicolumn{11}{|l|}{$\begin{array}{l}\text { Tri-State Generation \& } \\
\text { Transmission Assn } \\
\text { Craig }\end{array}$} \\
\hline 2014 & \multicolumn{11}{|l|}{$\begin{array}{l}\text { Commonwealth Edison Co } \\
\text { Crawford }\end{array}$} \\
\hline 2015 & Black Butte Coal Co & Various & WY & $\begin{array}{l}\text { Multi- } \\
\text { mode }\end{array}$ & 1,353 & 0.034 & 0.36 & 9,515 & NA & NA & 40.06 \\
\hline 2015 & Decker Coal Company & Various & MT & $\begin{array}{l}\text { Multi- } \\
\text { mode }\end{array}$ & 1,281 & 0.224 & 0.43 & 9,348 & NA & NA & 42.69 \\
\hline 2015 & \multicolumn{11}{|l|}{ Fisk } \\
\hline 2015 & Black Butte Coal Co & Various & WY & $\begin{array}{l}\text { Multi- } \\
\text { mode }\end{array}$ & 1,357 & 0.060 & 0.36 & 9,515 & NA & NA & 40.99 \\
\hline 02015 & Decker Coal Company & Various & MT & $\begin{array}{l}\text { Multi- } \\
\text { mode }\end{array}$ & 1,285 & 0.143 & 0.43 & 9,348 & NA & NA & 44.66 \\
\hline 2015 & $\begin{array}{l}\text { Decker Coal Company } \\
\text { Joliet }\end{array}$ & Various & MT & Rail & 1,371 & 0.143 & 0.43 & 9,348 & NA & NA & 44.66 \\
\hline 2015 & Black Butte Coal Co & Various & WY & Rail & 1,333 & 0.439 & 0.34 & 9,211 & NA & NA & 35.65 \\
\hline 2015 & $\begin{array}{l}\text { Decker Coal Company } \\
\text { Powerton }\end{array}$ & Various & MT & Rail & 1,301 & 1.227 & 0.38 & 9,574 & NA & NA & 38.45 \\
\hline 2015 & Black Butte Coal Co & Various & WY & Other & NA & 1.849 & 0.31 & 8,812 & NA & NA & 43.24 \\
\hline 2015 & Decker Coal Company & Various & MT & Rail & 1,143 & 0.535 & 0.20 & 8,749 & NA & NA & 34.00 \\
\hline
\end{tabular}

See notes at end of table. 
Table B1. Utility Contract Coal Shipment in 1993 by Expiration Date (Continued)

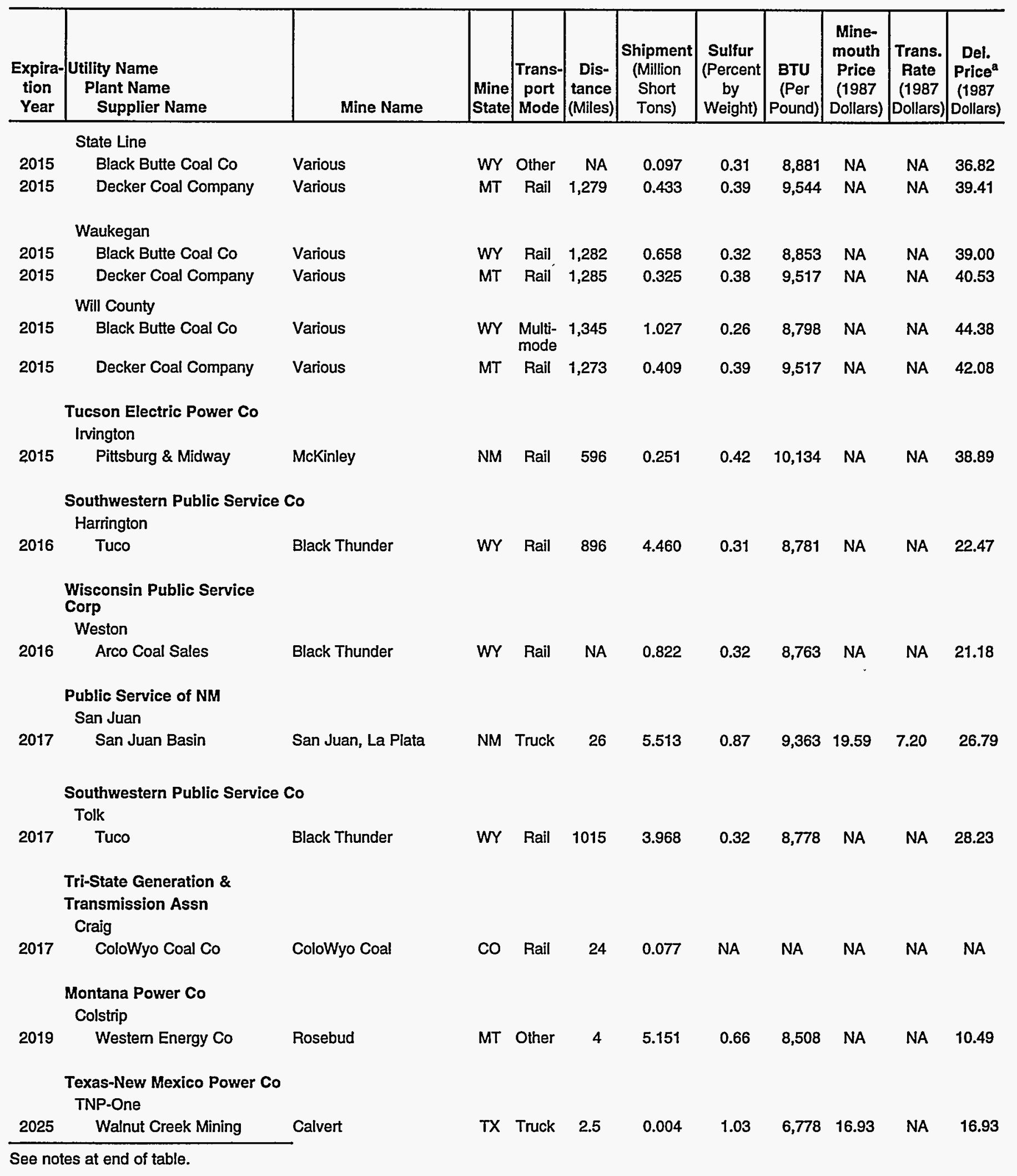




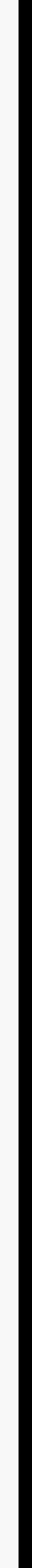


Appendix C

Contract Coal

Transportation Rates in Nominal Dollars 


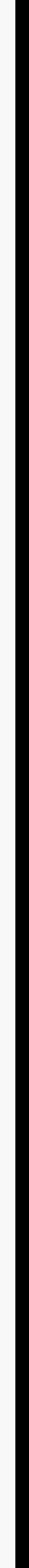




\section{Appendix C}

\section{Contract Coal Transportation Rates in Nominal Dollars}

Coal transportation rates are presented in nominal dollars in this appendix. Tables $\mathrm{C} 1$ through $\mathrm{C} 9$ present, in nominal dollars, the contract coal transportation rates by rail that pertain to Part I of the report. Tables $\mathrm{C} 10$ through C15 pertain to Part II of the report: Tables C10 and $\mathrm{C} 11$ contain the rate per ton and rate per ton-mile, respectively, for the United States; Table C12 presents rate per ton, and Table $\mathrm{C} 13$ shows rate per ton-mile, by demand region; and Tables C14 and C15 present the rate and rate per ton-mile, respectively, by supply region.
The gross domestic product deflators used to convert the nominal-dollar rates to constant-dollar rates in the body of the text are as follows:

$\begin{array}{lllllll}1979 & 0.655 & 1984 & 0.910 & 1989 & 1.085 \\ 1980 & 0.717 & 1985 & 0.944 & 1990 & 1.133 \\ 1981 & 0.789 & 1986 & 0.969 & 1991 & 1.176 \\ 1982 & 0.838 & 1987 & 1.000 & 1992 & 1.209 \\ 1983 & 0.872 & 1988 & 1.039 & 1993 & 1.235\end{array}$

Table C1. Average Rate per Ton for Contract Coal Rail Shipments by Sulfur Category, 1988-1993 (Nominal Dollars)

\begin{tabular}{|c|c|c|c|c|c|}
\hline \multirow[b]{2}{*}{ Year } & \multicolumn{5}{|c|}{ Sulfur Category } \\
\hline & All Coal & Compliance & Low & Medium & High \\
\hline 1988 & 11.51 & 14.95 & 11.17 & 8.58 & 5.57 \\
\hline $1989 \ldots$ & 11.21 & 14.54 & 11.74 & 6.86 & 5.07 \\
\hline $1990 \ldots \ldots \ldots \ldots \ldots \ldots$ & 11.13 & 15.15 & 10.35 & 8.26 & 4.97 \\
\hline $1991 \ldots \ldots$ & 11.07 & 14.35 & 10.46 & 8.28 & 5.14 \\
\hline $1992 \ldots$. & 10.75 & 14.10 & 10.25 & 7.11 & 4.91 \\
\hline $1993 \ldots \ldots \ldots \ldots \ldots \ldots$ & 11.02 & 13.26 & 10.36 & 7.40 & 4.87 \\
\hline
\end{tabular}

Notes: Compliance = less than or equal to 0.6 pounds of sulfur per million Btu; Low Sulfur $=0.61$ to 1.25 pounds per million Btu; Medium Sulfur = 1.26 to 1.67 pounds per million Btu; High-Sulfur = greater than 1.67 pounds per million Btu.

Source: Energy Information Administration, Coal Transportation Rate Data Base. 
Table C2. Average Rate per Million Btu for Contract Coal Rail Shipments by Sulfur Category, 1988-1993 (Cents per Million Btu in Nominal Dollars)

\begin{tabular}{|c|c|c|c|c|c|}
\hline \multirow[b]{2}{*}{ Year } & \multicolumn{5}{|c|}{ Sulfur Category } \\
\hline & All Coal & Compliance & Low & Medium & High \\
\hline 1988 & 53.7 & 77.4 & 47.6 & 37.2 & 24.5 \\
\hline $1989 \ldots$ & 52.6 & 76.5 & 49.8 & 29.9 & 22.3 \\
\hline $1990 \ldots$ & 52.1 & 80.9 & 44.7 & 35.2 & 21.7 \\
\hline$\ldots \ldots \ldots \ldots \ldots$ & 51.8 & 76.6 & 44.5 & 35.3 & 22.4 \\
\hline $1992 \ldots$ & 50.6 & 74.4 & 43.9 & 30.5 & 21.4 \\
\hline $1993 \ldots \ldots \ldots \ldots \ldots \ldots$ & 53.1 & 70.5 & 45.0 & 31.9 & 21.1 \\
\hline
\end{tabular}

Notes: Compliance $=$ less than or equal to 0.6 pounds of sulfur per million Btu; Low Sulfur $=0.61$ to 1.25 pounds per million Btu; Medium Sulfur $=1.26$ to 1.67 pounds per million Btu; High-Sulfur = greater than 1.67 pounds per million Btu.

Source: Energy Information Administration, Coal Transportation Rate Data Base.

Table C3. Average Rate per Ton-Mile for Contract Coal Rail Shipments by Sulfur Category, 1988-1993 (Mills per Ton-Mile in Nominal Dollars)

\begin{tabular}{|c|c|c|c|c|c|}
\hline \multirow[b]{2}{*}{ Year } & \multicolumn{5}{|c|}{ Sulfur Category } \\
\hline & All Coal & Compliance & Low & Medium & High \\
\hline 1988 & 19.8 & 16.2 & 24.6 & 36.7 & 40.4 \\
\hline$\ldots \ldots \ldots \ldots$ & 19.2 & 15.7 & 25.2 & 32.1 & 39.7 \\
\hline $1990 \ldots$ & 19.9 & 16.7 & 23.8 & 31.1 & 34.7 \\
\hline$\ldots \ldots \ldots \ldots$ & 19.6 & 16.3 & 24.0 & 32.3 & 35.3 \\
\hline$\ldots \ldots \ldots \ldots$ & 18.3 & 15.0 & 24.7 & 35.5 & 32.1 \\
\hline $1993 \ldots$ & 16.7 & 14.0 & 23.7 & 37.9 & 33.4 \\
\hline
\end{tabular}

Notes: Compliance $=$ less than or equal to 0.6 pounds of sulfur per million Btu; Low Sulfur $=0.61$ to 1.25 pounds per million Btu; Medium Sulfur $=1.26$ to 1.67 pounds per million Btu; High-Sulfur = greater than 1.67 pounds per million Btu.

Source: Energy Information Administration, Coal Transportation Rate Data Base.

Table C4. Average Rate per Ton for Contract Coal Rail Shipments by Demand Region, 1988-1993 (Nominal Dollars)

\begin{tabular}{|c|c|c|c|c|c|c|}
\hline Demand Region & 1988 & 1989 & 1990 & 1991 & 1992 & 1993 \\
\hline East North Central & 9.67 & 9.59 & 8.84 & 9.39 & 9.28 & 9.82 \\
\hline East South Central $\ldots \ldots \ldots$. & 6.70 & 5.64 & 5.65 & 6.42 & 5.65 & 4.92 \\
\hline Mid Atlantic $\ldots . .$. & 14.02 & 13.72 & 10.86 & 11.62 & 10.18 & 10.21 \\
\hline Mountain $\ldots \ldots \ldots \ldots \ldots$ & 9.07 & 8.73 & 7.54 & 7.06 & 6.99 & 7.05 \\
\hline New England $\ldots \ldots \ldots \ldots$ & 17.64 & 17.67 & 18.53 & 18.42 & 18.10 & 18.39 \\
\hline Pacific $\ldots \ldots \ldots \ldots \ldots$ & 16.63 & -- & $\ldots$ & -- & 16.29 & 16.49 \\
\hline South Atlantic ........... & 10.57 & 10.30 & 10.51 & 10.75 & 10.77 & 11.26 \\
\hline West North Central . ........ & 11.50 & 11.66 & 10.95 & 10.71 & 10.74 & 10.72 \\
\hline West South Central ........ & 19.44 & 18.13 & 19.06 & 17.89 & 17.17 & 16.58 \\
\hline U.S. Average $\ldots \ldots \ldots \ldots$. & 11.51 & 11.21 & 11.13 & 11.07 & 10.75 & 11.02 \\
\hline
\end{tabular}

$-=$ Not applicable.

Source: Energy Information Administration, Coal Transportation Rate Data Base. 
Table C5. Average Rate per Million Btu for Contract Coal Rail Shipments by Demand Region, 1988-1993 (Cents per Million Btu in Nominal Dollars)

\begin{tabular}{|c|c|c|c|c|c|c|}
\hline Demand Region & 1988 & 1989 & 1990 & 1991 & 1992 & 1993 \\
\hline East North Central & 44.0 & 43.6 & 40.6 & 43.1 & 42.6 & 46.2 \\
\hline East South Central ......... & 27.5 & 23.3 & 23.2 & 26.2 & 23.5 & 20.6 \\
\hline Mid Atlantic $\ldots \ldots \ldots \ldots \ldots$ & 53.6 & 52.6 & 42.5 & 45.2 & 39.8 & 40.0 \\
\hline Mountain $\ldots \ldots \ldots \ldots \ldots$ & 46.2 & 44.4 & 40.1 & 37.6 & 37.0 & 37.5 \\
\hline New England ..... & 66.0 & 66.0 & 69.7 & 69.5 & 68.1 & 69.7 \\
\hline Pacific ............... & 98.6 & - & -- & -- & 85.6 & 87.3 \\
\hline South Atlantic . . . . . . . . & 42.4 & 41.5 & 42.1 & 43.1 & 42.8 & 44.7 \\
\hline West North Central ......... & 66.6 & 68.5 & 60.8 & 59.4 & 59.7 & 61.2 \\
\hline West South Central .......... & 109.8 & 102.4 & 109.1 & 101.4 & 97.1 & 94.3 \\
\hline U.S. Average . . . . . . . . . . & 53.7 & 52.6 & 52.1 & 51.8 & 50.6 & 53.1 \\
\hline
\end{tabular}

-- = Not applicable.

Source: Energy Information Administration, Coal Transportation Rate Data Base.

Table C6. Average Rate per Ton-Mile for Contract Coal Rail Shipments by Demand Region, 1988-1993 (Mills per Ton-Mile in Nominal Dollars)

\begin{tabular}{|c|c|c|c|c|c|c|}
\hline Demand Region & 1988 & 1989 & 1990 & 1991 & 1992 & 1993 \\
\hline East North Central $\ldots \ldots \ldots$ & 21.3 & 20.9 & 19.6 & 18.4 & 18.1 & 14.7 \\
\hline East South Central ........ & 20.6 & $21 . \dot{8}$ & 23.3 & 23.7 & 18.0 & 18.2 \\
\hline Mid Atlantic $\ldots \ldots \ldots \ldots \ldots$ & 32.2 & 32.6 & 35.4 & 36.2 & 36.8 & 36.6 \\
\hline Mountain $\ldots \ldots \ldots \ldots \ldots$ & 26.2 & 26.3 & 26.8 & 26.5 & 27.2 & 26.8 \\
\hline New England $\ldots \ldots \ldots \ldots$ & 20.2 & 20.2 & 22.0 & 21.9 & 21.3 & 21.6 \\
\hline Pacific $\ldots \ldots \ldots \ldots \ldots \ldots$ & 15.2 & - &.- & -- & 15.3 & 15.4 \\
\hline South Atlantic . . . . . . . . . . & 31.7 & 32.0 & 27.9 & 28.5 & 28.3 & 28.1 \\
\hline West North Central ......... & 15.1 & 14.9 & 15.8 & 15.4 & 14.7 & 13.3 \\
\hline West South Central ......... & 14.8 & 13.8 & 16.5 & 16.0 & 14.2 & 14.0 \\
\hline U.S. Average . . . . . . . . . & 19.8 & 19.2 & 19.9 & 19.6 & 18.3 & 16.7 \\
\hline
\end{tabular}

$-=$ Not applicable.

Source: Energy Information Administration, Coal Transportation Rate Data Base. 
Table C7. Average Rate per Ton for Contract Coal Rail Shipments by Supply Region, 1988-1993 (Nominal Dollars)

\begin{tabular}{|c|c|c|c|c|c|c|}
\hline Supply Region & 1988 & 1989 & 1990 & 1991 & 1992 & 1993 \\
\hline Central Appalachia ........... & 12.20 & 12.14 & 11.30 & 11.62 & 11.39 & 11.64 \\
\hline Illinois Basin..$\ldots \ldots \ldots \ldots$. . . & 4.05 & 3.47 & 3.81 & 3.95 & 3.77 & 3.54 \\
\hline North Dakota Lignite . . . . . . . . & 8.00 & 7.90 & 6.94 & 6.67 & 6.67 & 6.61 \\
\hline Northern Appalachia ... & 9.53 & 9.31 & 10.09 & 10.42 & 9.27 & 9.76 \\
\hline Other Western Interior . . . . . . . & 2.45 & 7.40 & 6.47 & 7.61 & 7.98 & 8.16 \\
\hline Powder River Basin & 15.43 & 15.06 & 15.12 & 14.31 & 13.92 & 13.04 \\
\hline Rockies $\ldots \ldots \ldots \ldots \ldots$. & 14.68 & 13.41 & 12.76 & 13.05 & 14.72 & 13.90 \\
\hline Southern Appalachia .......... & 4.54 & 3.86 & 4.33 & 4.26 & 4.82 & 4.67 \\
\hline Southwest ... & 6.83 & 6.50 & 6.63 & 6.36 & 6.18 & 8.69 \\
\hline U.S. Average $\ldots \ldots \ldots \ldots \ldots$ & 11.51 & 11.21 & 11.13 & 11.07 & 10.75 & 11.02 \\
\hline
\end{tabular}

- = Not applicable.

Source: Energy Information Administration, Coal Transportation Rate Data Base.

Table C8. Average Rate per Million Btu for Contract Coal Rail Shipments by Supply Region, 1988-1993 (Cents per Million Btu in Nominal Dollars)

\begin{tabular}{|c|c|c|c|c|c|c|}
\hline Supply Region & 1988 & 1989 & 1990 & 1991 & 1992 & 1993 \\
\hline Central Appalachia & 48.1 & 48.1 & 45.8 & 47.2 & 45.3 & 46.3 \\
\hline Illinois Basin . . . . . . & 18.3 & 15.7 & 17.1 & 17.7 & 16.9 & 15.8 \\
\hline North Dakota Lignite .......... & 63.4 & 62.9 & 55.4 & 53.5 & 54.1 & 53.2 \\
\hline Northem Appalachia & 38.3 & 37.4 & 39.7 & 40.5 & 36.4 & 38.2 \\
\hline Other Western Interior $\ldots \ldots \ldots \ldots$ & 10.0 & 31.5 & 27.5 & 31.8 & 33.3 & 34.7 \\
\hline Powder River Basin & 88.0 & 86.1 & 87.3 & 82.2 & 79.6 & 74.8 \\
\hline Rockies $\ldots \ldots \ldots \ldots \ldots \ldots$. & 65.8 & 60.3 & 57.4 & 57.8 & 64.9 & 61.9 \\
\hline Southem Appalachia .......... & 18.4 & 15.8 & 17.4 & 17.3 & 20.0 & 19.5 \\
\hline Southwest $\ldots . .$. & 34.4 & 33.0 & 34.5 & 33.2 & 32.3 & 42.7 \\
\hline U.S. Average $\ldots \ldots \ldots \ldots \ldots$ & 53.7 & 52.6 & 52.1 & 51.8 & 50.6 & 53.1 \\
\hline
\end{tabular}

$--=$ Not applicable.

Source: Energy Information Administration, Coal Transportation Rate Data Base. 
Table C9. Average Rate per Ton-Mile for Contract Coal Rail Shipments by Supply Region, 1988-1993 (Mills per Ton-Mile in Nominal Dollars)

\begin{tabular}{|c|c|c|c|c|c|c|}
\hline Supply Region & 1988 & 1989 & 1990 & 1991 & 1992 & 1993 \\
\hline Central Appalachia $\ldots \ldots \ldots \ldots$ & 27.1 & 28.2 & 26.8 & 27.0 & 25.4 & 25.7 \\
\hline Illinois Basin . . . . . . . & 34.9 & 34.9 & 34.7 & 34.2 & 32.3 & 37.3 \\
\hline North Dakota Lignite . . . . . . . . . & 26.4 & 26.6 & 23.1 & 21.9 & 21.7 & 21.9 \\
\hline Northern Appalachia .......... & 41.7 & 39.6 & 33.0 & 33.9 & 33.9 & 34.4 \\
\hline Other Western Interior . ......... & 97.8 & 45.4 & 37.1 & 38.1 & 39.9 & 40.8 \\
\hline Powder River Basin $\ldots \ldots \ldots \ldots$ & 15.1 & 14.6 & 15.5 & 14.8 & 14.1 & 13.1 \\
\hline Rockies...$\ldots \ldots \ldots \ldots$ & 21.2 & 20.9 & 20.0 & 20.2 & 19.4 & 18.1 \\
\hline Southern Appalachia . .......... & 38.4 & 30.2 & 34.0 & 32.6 & 33.4 & - 30.3 \\
\hline Southwest $\ldots \ldots \ldots \ldots \ldots \ldots$ & 37.9 & 39.2 & 41.6 & 42.1 & 36.7 & 22.2 \\
\hline U.S. Average $\ldots \ldots \ldots \ldots \ldots \ldots$ & 19.8 & 19.2 & 19.9 & 19.6 & 18.3 & 16.7 \\
\hline
\end{tabular}

-- = Not applicable.

Source: Energy Information Administration, Coal Transportation Rate Data Base.

Table C10. Average Utility Contract Coal Transportation Rate per Ton by Transportation Mode, 1979-1993 (Nominal Dollars per Short Ton)

\begin{tabular}{|c|c|c|c|c|c|c|c|}
\hline & Year & Rail & Barge & Truck & Multimode $^{a}$ & Other ${ }^{b}$ & U.S. Average \\
\hline 1979 & $\ldots \ldots \ldots \ldots \ldots$ & 7.08 & 1.79 & 4.49 & 10.48 & 1.72 & 6.62 \\
\hline 1980 & $\ldots \ldots \ldots \ldots$ & 8.03 & 2.09 & 4.66 & 11.89 & 1.56 & 7.44 \\
\hline 1981 & $\ldots \ldots \ldots \ldots \ldots$ & 9.64 & 3.07 & 6.37 & 13.50 & 2.09 & 9.06 \\
\hline 1982 & $\ldots \ldots \ldots \ldots \ldots$ & 10.36 & 2.94 & 5.51 & 12.34 & 2.14 & 9.33 \\
\hline 1983 & $\ldots \ldots$ & 10.88 & 3.21 & 4.63 & 14.65 & 3.00 & 9.88 \\
\hline 1984 & $\ldots \ldots \ldots \ldots$ & 12.11 & 4.55 & 5.00 & 17.78 & 1.98 & 10.77 \\
\hline 1985 & $\ldots \ldots \ldots \ldots$ & 11.36 & 3.01 & 3.23 & 17.13 & 1.63 & 10.11 \\
\hline 1986 & $\ldots \ldots \ldots \ldots \ldots$ & 10.66 & 2.79 & 4.18 & 13.18 & 2.67 & 9.15 \\
\hline 1987 & $\ldots \ldots \ldots \ldots \ldots$ & 10.31 & 2.85 & 4.03 & 11.82 & 2.85 & 8.65 \\
\hline 1988 & $\ldots \ldots \ldots$ & 11.51 & 2.81 & 3.57 & 16.97 & 3.26 & 10.40 \\
\hline 1989 & $\ldots \ldots \ldots \ldots \ldots$ & 11.21 & 3.03 & 3.28 & 17.07 & 4.49 & 10.23 \\
\hline 1990 & $\ldots \ldots \ldots \ldots$ & 11.13 & 2.54 & 4.20 & 14.64 & 1.87 & 9.70 \\
\hline 1991 & $\ldots \ldots \ldots \ldots$ & 11.07 & 2.67 & 4.78 & 13.73 & 1.89 & 9.45 \\
\hline 1992 & $\ldots \ldots \ldots \ldots \ldots$ & 10.75 & 3.68 & 4.40 & 13.12 & 2.19 & 9.47 \\
\hline 1993 & $\ldots \ldots \ldots \ldots \ldots$ & 11.02 & 3.47 & 4.39 & 13.13 & 2.33 & 9.67 \\
\hline
\end{tabular}

ancludes shipments that use any combination of rail, barge, and collier transportation.

bIncludes conveyor, tramway, slurry pipeline, and shipments for which mode is unknown.

Source: Federal Energy Regulatory Commission, FERC Form 580, "Interrogatory on Fuel and Energy Purchase Practices." 
Table C11. Average Utility Contract Coal Transportation Rate per Ton-Mile by Transportation Mode, 1979-1993

(Mills in Nominal Dollars)

\begin{tabular}{|c|c|c|c|c|c|c|}
\hline Year & Rail & Barge & Truck & Multimode $^{\mathrm{a}}$ & Other ${ }^{b}$ & All Modes \\
\hline $1979 \ldots$. & 14.7 & 8.0 & 65.2 & 14.0 & $21 . \uparrow$ & 14.5 \\
\hline $1980 \ldots \ldots \ldots \ldots \ldots \ldots$ & 16.2 & 8.9 & 70.3 & 16.1 & 22.0 & 16.1 \\
\hline $1981 \ldots$ & 18.3 & 11.6 & 102.6 & 17.8 & 25.4 & 18.3 \\
\hline $1982 \ldots \ldots \ldots \ldots \ldots \ldots$ & 20.7 & 11.4 & 98.9 & 25.5 & 20.9 & 21.3 \\
\hline $1983 \ldots \ldots \ldots \ldots \ldots \ldots$ & 21.5 & 12.4 & 136.0 & 26.6 & 43.1 & 22.5 \\
\hline $1984 \ldots \ldots \ldots \ldots \ldots \ldots$ & 23.8 & 17.8 & 265.6 & 21.9 & 35.0 & 23.7 \\
\hline $1985 \ldots \ldots \ldots \ldots \ldots \ldots$ & 22.1 & 10.0 & 110.6 & 21.8 & 36.0 & 21.7 \\
\hline $1986 \ldots$ & 22.8 & 9.4 & 168.2 & 23.7 & 19.0 & 22.9 \\
\hline $1987 \ldots$ & 22.5 & 9.2 & 162.0 & 22.0 & 27.6 & 22.6 \\
\hline $1988 \ldots \ldots \ldots \ldots \ldots \ldots$ & 19.8 & 9.4 & 164.3 & 20.0 & 18.6 & 19.6 \\
\hline $1989 \ldots \ldots \ldots \ldots \ldots \ldots$ & 19.2 & 10.7 & 162.0 & 18.3 & 29.6 & 19.1 \\
\hline $1990 \ldots \ldots \ldots \ldots \ldots \ldots$ & 19.9 & 9.3 & 166.2 & 13.7 & 30.5 & 18.5 \\
\hline$\ldots \ldots \ldots \ldots$ & 19.6 & 9.1 & 114.2 & 13.2 & 29.5 & 18.1 \\
\hline $1992 \ldots \ldots \ldots \ldots \ldots \ldots$ & 18.3 & 9.8 & 132.8 & 12.8 & 29.1 & 16.8 \\
\hline $1993 \ldots \ldots \ldots \ldots \ldots \ldots$ & 16.7 & 9.9 & 104.0 & 12.4 & 26.7 & 15.9 \\
\hline
\end{tabular}

ancludes shipments that use any combination of rail, barge, and collier transportation.

Includes conveyor, tramway, slurry pipeline, and shipments for which mode is unknown.

Source: Federal Energy Regulatory Commission, FERC Form 580, "Interrogatory on Fuel and Energy Purchase Practices." 
Table C12. Average Utility Contract Coal Transportation Rate per Ton by Demand Region and Transportation Mode, 1979, 1986, and 1993 (Nominal Dollars)

\begin{tabular}{|c|c|c|c|}
\hline Supply Region & 1979 & 1986 & 1993 \\
\hline \multicolumn{4}{|l|}{ Northeast } \\
\hline Rail $\ldots \ldots \ldots \ldots \ldots \ldots \ldots \ldots \ldots \ldots \ldots$ & 7.62 & 10.93 & 11.30 \\
\hline 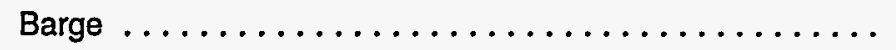 & 1.13 & 1.53 & 2.87 \\
\hline Truck $\ldots \ldots \ldots \ldots \ldots \ldots \ldots \ldots \ldots \ldots \ldots$ & 5.90 & 5.13 & 8.22 \\
\hline Multimode ${ }^{\mathrm{a}} \ldots \ldots \ldots \ldots \ldots \ldots \ldots \ldots \ldots \ldots$ & 13.62 & 18.06 & 16.39 \\
\hline Other ${ }^{b} \ldots \ldots \ldots \ldots \ldots \ldots \ldots \ldots \ldots \ldots \ldots$ & -- & - & -- \\
\hline Region Average $\ldots \ldots \ldots \ldots \ldots \ldots \ldots \ldots \ldots$ & 6.15 & 8.14 & 10.10 \\
\hline \multicolumn{4}{|l|}{ Midwest } \\
\hline Rail $\ldots \ldots \ldots \ldots \ldots \ldots \ldots \ldots \ldots \ldots \ldots$ & 7.56 & 7.57 & 10.24 \\
\hline 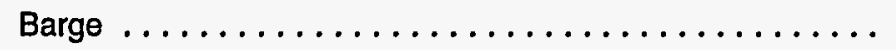 & 1.78 & 2.39 & 1.99 \\
\hline Truck $\ldots \ldots \ldots \ldots \ldots \ldots \ldots \ldots \ldots \ldots$ & 4.43 & 2.70 & 4.17 \\
\hline Multimode $^{a} \ldots \ldots \ldots \ldots \ldots \ldots \ldots \ldots \ldots$ & 11.88 & 15.60 & 13.51 \\
\hline Other ${ }^{b} \ldots \ldots \ldots \ldots \ldots \ldots \ldots \ldots \ldots \ldots \ldots$ & 0.66 & 0.09 & 1.11 \\
\hline Region Average $\ldots \ldots \ldots \ldots \ldots \ldots \ldots \ldots \ldots$ & 7.37 & 7.83 & 9.15 \\
\hline \multicolumn{4}{|l|}{ South } \\
\hline$\ldots \ldots \ldots \ldots$ & 7.31 & 13.97 & 12.88 \\
\hline Barge $\ldots \ldots \ldots \ldots \ldots \ldots \ldots \ldots \ldots \ldots \ldots \ldots \ldots$ & 2.24 & 5.19 & 5.70 \\
\hline Truck $\ldots \ldots \ldots \ldots \ldots \ldots \ldots \ldots \ldots \ldots$ & 4.11 & 4.20 & 2.98 \\
\hline Multimode $^{\mathrm{a}} \ldots \ldots \ldots \ldots \ldots \ldots \ldots \ldots \ldots \ldots$ & 5.40 & 6.51 & 10.81 \\
\hline Other $\ldots \ldots \ldots \ldots \ldots \ldots \ldots \ldots \ldots \ldots \ldots \ldots$ & 2.59 & - & -- \\
\hline Region Average $\ldots \ldots \ldots \ldots \ldots \ldots \ldots \ldots \ldots$ & 6.49 & 12.37 & 11.73 \\
\hline \multicolumn{4}{|l|}{ West } \\
\hline$\ldots \ldots \ldots \ldots \ldots$ & 3.01 & 7.27 & 7.29 \\
\hline$\ldots \ldots \ldots \ldots \ldots \ldots \ldots$ & 3.57 & 4.91 & 4.58 \\
\hline Other ${ }^{b} \ldots \ldots \ldots \ldots$ & 2.91 & 3.31 & 3.11 \\
\hline Region Average $\ldots \ldots \ldots \ldots \ldots \ldots \ldots \ldots \ldots$ & 3.03 & 4.90 & 5.76 \\
\hline \multicolumn{4}{|l|}{ United States } \\
\hline Rail ........... & 7.08 & 10.66 & 11.02 \\
\hline Barge $\ldots \ldots \ldots \ldots \ldots \ldots \ldots \ldots \ldots \ldots \ldots$ & 1.79 & 2.79 & 3.47 \\
\hline Truck $\ldots \ldots \ldots \ldots \ldots \ldots \ldots \ldots \ldots \ldots \ldots$ & 4.49 & 4.18 & 4.39 \\
\hline Multimode ${ }^{\mathrm{a}} \ldots$ & 10.48 & 13.18 & 13.13 \\
\hline Other ${ }^{b} \ldots \ldots$ & 1.72 & 2.67 & 2.33 \\
\hline U.S. Average $\ldots \ldots \ldots \ldots \ldots \ldots \ldots \ldots \ldots \ldots$ & 6.62 & 9.15 & 9.67 \\
\hline
\end{tabular}

ancludes shipments that use any combination of rail, barge, and collier transportation.

Includes conveyor, tramway, slurry pipeline, and shipments for which mode is unknown.

$--=$ Not applicable.

Source: Federal Energy Regulatory Commission, FERC Form 580, "Interrogatory on Fuel and Energy Purchase Practices." 
Table C13. Average Utility Contract Coal Transportation Rate Per Ton-Mile by Demand Region and Transportation Mode, 1979, 1986 and 1993 (Mills in Nominal Dollars)

\begin{tabular}{|c|c|c|c|}
\hline Demand Region & 1979 & 1986 & 1993 \\
\hline \multicolumn{4}{|l|}{ Northeast } \\
\hline Rail $\ldots \ldots \ldots \ldots \ldots$ & 22.3 & 34.8 & 31.1 \\
\hline Barge $\ldots \ldots \ldots \ldots$ & 20.8 & 19.4 & 52.0 \\
\hline$\ldots \ldots \ldots$ & 52.6 & 89.4 & 23.5 \\
\hline Multimode ${ }^{\mathrm{a}}$ & 25.5 & 29.1 & 21.4 \\
\hline Otherb .... & -- & - & - \\
\hline Region Average... . & 24.1 & 33.2 & 28.9 \\
\hline \multicolumn{4}{|l|}{ Midwest } \\
\hline Rail $\ldots \ldots \ldots \ldots \ldots$ & 13.8 & 24.4 & 14.4 \\
\hline Barge $\ldots \ldots \ldots \ldots$ & 6.9 & 10.1 & 8.2 \\
\hline Truck $\ldots . . . \ldots \ldots$ & 59.4 & 82.4 & 84.0 \\
\hline Multimode $^{\mathrm{a}} \ldots \ldots \ldots$ & 13.3 & 25.1 & 10.9 \\
\hline Other ${ }^{b} \ldots \ldots \ldots \ldots$ & 86.1 & - & 122.6 \\
\hline Region Average $\ldots$. & 13.5 & 23.7 & 13.2 \\
\hline \multicolumn{4}{|l|}{ South } \\
\hline Rail . & 15.4 & 21.1 & 18.2 \\
\hline Barge $\ldots \ldots \ldots \ldots \ldots$ & 7.7 & 7.4 & 9.3 \\
\hline Truck .... & 467.2 & 296.6 & 89.2 \\
\hline Multimode $^{\mathrm{a}} \ldots \ldots \ldots$ & 15.9 & 19.3 & 19.8 \\
\hline Other ${ }^{b} \ldots$ & -. & -- & -- \\
\hline Region Average... . & 15.0 & 20.4 & 17.5 \\
\hline \multicolumn{4}{|l|}{ West } \\
\hline$\ldots \ldots \ldots \ldots$ & 14.7 & 33.1 & 25.7 \\
\hline Truck & 112.0 & 263.0 & 244.8 \\
\hline Other $\ldots \ldots \ldots \ldots$ & 17.0 & 19.0 & 23.8 \\
\hline Region Average... . & 16.7 & 43.3 & 29.1 \\
\hline \multicolumn{4}{|l|}{ United States } \\
\hline Rail ........ & 14.7 & 22.8 & 16.7 \\
\hline Barge $\ldots \ldots \ldots \ldots$ & 8.0 & 9.4 & 9.9 \\
\hline Truck ........... & 65.2 & 168.2 & 104.0 \\
\hline Multimode $^{\mathrm{a}} \ldots \ldots$ & 14.0 & 23.7 & 12.4 \\
\hline Other $^{b} \ldots \ldots \ldots$ & 21.1 & 19.0 & 26.7 \\
\hline U.S. Average . . . . . . . & 14.5 & 22.9 & 15.9 \\
\hline
\end{tabular}

ancludes shipments that use any combination of rail, barge, and collier transportation.

Includes conveyor, tramway, slurry pipeline, and shipments for which mode is unknown.

$--=$ Not applicable.

Source: Federal Energy Regulatory Commission, FERC Form 580, "Interrogatory on Fuel and Energy Purchase Practices." 
Table C14. Average Utility Contract Coal Transportation Rate Per Ton by Supply Region and Transportation Mode, 1979, 1986, and 1993

(Nominal Dollars)

\begin{tabular}{|c|c|c|c|}
\hline Supply Region & 1979 & 1986 & 1993 \\
\hline \multicolumn{4}{|l|}{ Appalachia } \\
\hline 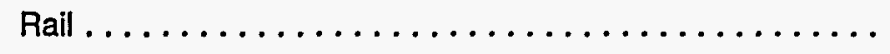 & 6.84 & 10.69 & 10.83 \\
\hline 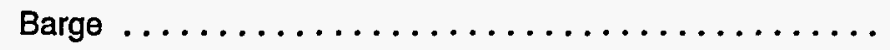 & 1.37 & 2.30 & 3.24 \\
\hline Truck $\ldots \ldots \ldots \ldots \ldots \ldots \ldots \ldots \ldots \ldots \ldots \ldots \ldots \ldots \ldots \ldots \ldots$ & 4.54 & 4.52 & 3.48 \\
\hline Multimode $^{a} \ldots \ldots \ldots \ldots \ldots \ldots \ldots \ldots \ldots \ldots \ldots \ldots \ldots \ldots$ & 8.16 & 11.10 & 11.39 \\
\hline 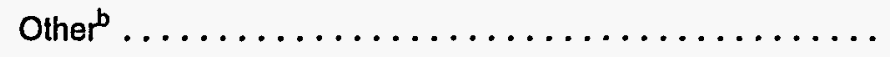 & 1.04 & 12.26 & 1.11 \\
\hline Region Average $\ldots \ldots \ldots \ldots \ldots \ldots \ldots \ldots \ldots$ & 5.61 & 9.30 & 8.54 \\
\hline \multicolumn{4}{|l|}{ Interior } \\
\hline Rail $\ldots \ldots \ldots \ldots \ldots \ldots \ldots \ldots \ldots \ldots \ldots \ldots \ldots \ldots \ldots \ldots$ & 3.35 & 4.51 & 3.55 \\
\hline 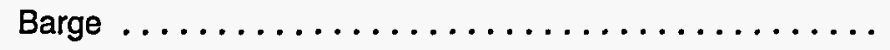 & 2.79 & 3.95 & 4.22 \\
\hline Truck $\ldots \ldots \ldots \ldots \ldots \ldots \ldots \ldots \ldots \ldots \ldots$ & 5.40 & 3.40 & 3.79 \\
\hline 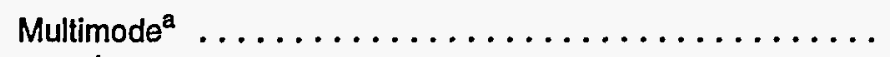 & 4.80 & 5.54 & 5.22 \\
\hline 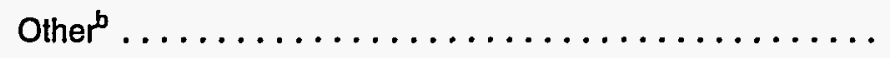 & -- & -- & -- \\
\hline Region Average $\ldots \ldots \ldots \ldots \ldots \ldots \ldots \ldots \ldots$ & 3.48 & 4.38 & 3.80 \\
\hline \multicolumn{4}{|l|}{ Western } \\
\hline 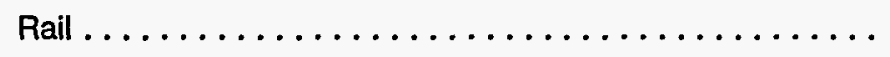 & 9.57 & 18.17 & 12.67 \\
\hline Truck $\ldots \ldots \ldots \ldots \ldots \ldots \ldots \ldots \ldots \ldots \ldots \ldots \ldots \ldots \ldots$ & 3.57 & 4.50 & 5.06 \\
\hline Multimode $^{\mathrm{a}} \ldots \ldots$ & 16.37 & 19.85 & 15.43 \\
\hline Other ${ }^{b} \ldots \ldots \ldots$ & 2.91 & 2.66 & 3.11 \\
\hline Region Average $\ldots \ldots \ldots \ldots \ldots \ldots \ldots \ldots \ldots$ & 9.98 & 13.17 & 12.05 \\
\hline \multicolumn{4}{|l|}{ United States } \\
\hline$\ldots \ldots \ldots \ldots \ldots \ldots \ldots \ldots \ldots$ & 7.08 & 10.66 & 11.02 \\
\hline Barge $\ldots \ldots \ldots \ldots \ldots \ldots \ldots \ldots \ldots \ldots \ldots \ldots$ & 1.79 & 2.79 & 3.47 \\
\hline Truck $\ldots \ldots \ldots \ldots \ldots \ldots \ldots \ldots \ldots \ldots \ldots \ldots \ldots$ & 4.49 & 4.18 & 4.39 \\
\hline Multimode $^{a} \ldots \ldots \ldots \ldots \ldots \ldots \ldots \ldots \ldots \ldots \ldots \ldots \ldots \ldots \ldots$ & 10.48 & 13.18 & 13.13 \\
\hline Other ${ }^{b} \ldots \ldots \ldots \ldots \ldots \ldots \ldots \ldots \ldots \ldots \ldots \ldots$ & 1.72 & 2.67 & 2.33 \\
\hline U.S. Average $\ldots \ldots \ldots \ldots \ldots \ldots \ldots \ldots \ldots \ldots$ & 6.62 & 9.15 & 9.67 \\
\hline
\end{tabular}

ancludes shipments that use any combination of rail, barge, and collier transportation.

Includes conveyor, tramway, slurry pipeline, and shipments for which mode is unknown.

-- = Not applicable.

Source: Federal Energy Regulatory Commission, FERC Form 580, "Interrogatory on Fuel and Energy Purchase Practices." 
Table C15. Average Utility Contract Coal Transportation Rate Per Ton-Mile by Supply Region and Transportation Mode, 1979, 1986, and 1993

(Mills in Nominal Dollars)

\begin{tabular}{|c|c|c|c|}
\hline Supply Region & 1979 & 1986 & 1993 \\
\hline \multicolumn{4}{|l|}{ Appalachia } \\
\hline Rail . . . . . . . . . . & 21.0 & 29.4 & 27.8 \\
\hline Barge $\ldots \ldots \ldots \ldots$ & 12.5 & 11.7 & 12.7 \\
\hline Truck ........... & 54.6 & 102.5 & 47.4 \\
\hline Multimode $^{\mathrm{a}} \ldots \ldots \ldots$ & 19.1 & 29.3 & 21.0 \\
\hline Other $^{b} \ldots \ldots \ldots \ldots$ & 86.1 & -- & 122.6 \\
\hline Region Average .... & 20.4 & 28.3 & 24.5 \\
\hline \multicolumn{4}{|l|}{ Interior } \\
\hline Rail . . . . . . . . . . & 20.4 & 27.4 & 37.3 \\
\hline Barge $\ldots \ldots \ldots \ldots$ & 5.7 & 73.0 & 5.4 \\
\hline Truck $\ldots \ldots \ldots \ldots$ & 58.5 & 122.7 & 79.3 \\
\hline Multimode $^{\mathrm{a}} \ldots \ldots \ldots$ & 13.0 & 14.9 & 20.3 \\
\hline Other $^{b} \ldots \ldots \ldots \ldots$ & $\cdots$ & -- & - \\
\hline Region Average . . . . & 15.9 & 21.9 & 19.0 \\
\hline \multicolumn{4}{|l|}{ Western } \\
\hline Rail . . . . . . . . . & 11.8 & 17.4 & 13.6 \\
\hline Truck $\ldots \ldots \ldots \ldots$ & 112.0 & 260.7 & 173.4 \\
\hline Multimode $^{\mathrm{a}} \ldots \ldots \ldots$ & 12.0 & 16.7 & 10.0 \\
\hline Other $^{b} \ldots \ldots \ldots \ldots$ & 17.0 & 19.0 & 23.8 \\
\hline Region Average $\ldots$. . & 12.0 & 18.8 & 13.3 \\
\hline \multicolumn{4}{|l|}{ United States } \\
\hline Rail ....... & 14.7 & 22.8 & 16.7 \\
\hline Barge $\ldots \ldots \ldots \ldots$ & 8.0 & 9.4 & 9.9 \\
\hline Truck $\ldots \ldots \ldots \ldots$ & 65.2 & 168.2 & 104.0 \\
\hline Multimode $^{\mathrm{a}} \ldots \ldots \ldots$ & 14.0 & 23.7 & 12.4 \\
\hline Other $^{b} \ldots \ldots \ldots \ldots$ & 21.1 & 19.0 & 26.7 \\
\hline U.S. Average . . . . . & 14.5 & 22.9 & 15.9 \\
\hline
\end{tabular}

ancludes shipments that use any combination of rail, barge, and collier transportation.

'Includes conveyor, tramway, slurry pipeline, and shipments for which mode is unknown.

-- = Not applicable.

Source: Federal Energy Regulatory Commission, FERC Form 580, "Interrogatory on Fuel and Energy Purchase Practices." 


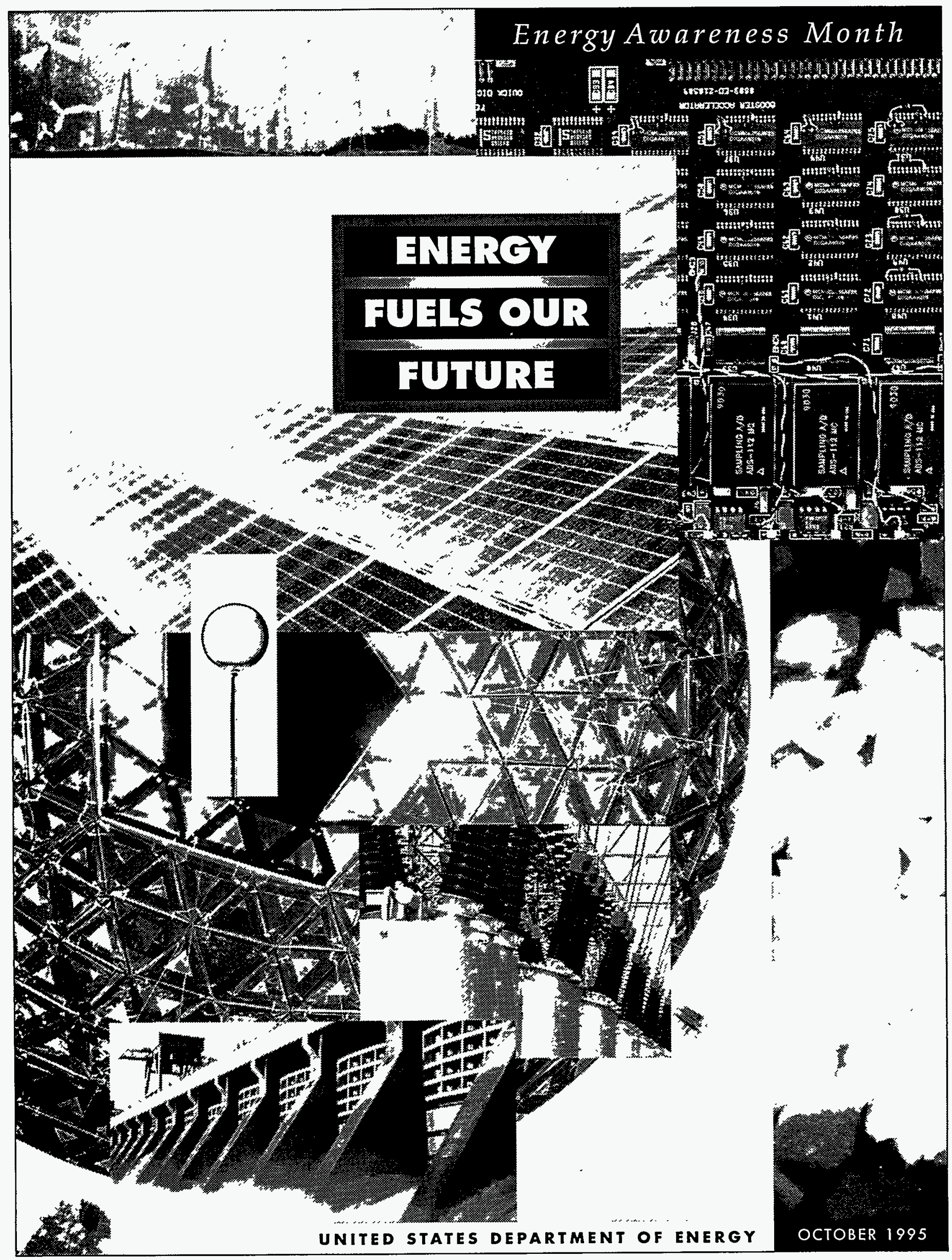

